\title{
ESTUDO COMPARATIVO DA MATURAÇÃO E ERUPÇÃO DOS DENTES PERMANENTES EM JOVENS COM PADRÕES DE CRESCIMENTO VERTICAL E HORIZONTAL
}

\section{LENIANA SANTOS NEVES}

\author{
Dissertação apresentada à \\ Faculdade de Odontologia de Bauru - \\ Universidade de São Paulo, como parte \\ dos requisitos para a obtenção do título de \\ Mestre em Odontologia, área de \\ Ortodontia.
}

(Edição Revisada)

Bauru 


\title{
ESTUDO COMPARATIVO DA MATURAÇÃO E ERUPÇÃO DOS DENTES PERMANENTES EM JOVENS COM PADRÕES DE CRESCIMENTO VERTICAL E HORIZONTAL
}

\section{LENIANA SANTOS NEVES}

\author{
Dissertação apresentada à \\ Faculdade de Odontologia de Bauru - \\ Universidade de São Paulo, como parte \\ dos requisitos para a obtenção do título de \\ Mestre em Odontologia, área de \\ Ortodontia.
}

(Edição Revisada)

Orientador: Prof. Dr. Arnaldo Pinzan

Bauru 


\begin{tabular}{|c|c|}
\hline N414e & $\begin{array}{l}\text { Neves, Leniana Santos } \\
\text { Estudo comparativo da maturaçăo e erupção dos dentes } \\
\text { permanentes em jovens com padröes de crescimento vertical e } \\
\text { horizontal / Leniana Santos Neves. - Bauru, } 2003 \text {. } \\
\text { xvii, } 133 \text { p. : il. ; } 30 \mathrm{~cm} \text {. }\end{array}$ \\
\hline & $\begin{array}{l}\text { Dissertação (Mestrado) - Faculdade de Odontologia de Bauru. } \\
\text { Universidade de Săo Paulo. }\end{array}$ \\
\hline & Orientador: Prof. Dr. Arnaldo Pinzan \\
\hline
\end{tabular}

Autorizo, exclusivamente para fins acadêmicos e científicos, a reproduçăo total ou parcial desta dissertação, por processos fotocopiadores e outros meios eletrônicos.

Bauru, 29 de novembro de 2002.

Assinatura: Leavious butherpers

Projeto de Pesquisa aprovado pelo Comitê de Ética em Pesquisa da Faculdade de Odontologia de Bauru, Universidade de Săo Paulo. Of. $n^{\circ}$ CEP/11 2002/FOB 


\section{LENIANA SANTOS NEVES}

06 de outubro de 1973

Diamantina - MG

Filiação

$1993-1996$

$1999-2001$

$2001-2003$
Nascimento

Amauri José Neves

Maria Helena Santos Neves

Curso de Graduação em Odontologia na Faculdade Federal de Odontologia de Diamantina.

Curso de Aperfeiçoamento em Ortodontia e Ortopedia Dentofacial pela ACOPEN Assessoria e Consultoria de Ortodontia, Pesquisa e Ensino.

Curso de Pós-Graduação em nível de Mestrado, área de Ortodontia, pela Faculdade de Odontologia de Bauru, Universidade de São Paulo - FOB/USP. 


\title{
DEDICO ESTE TRABALHO
}

\begin{abstract}
À Deus, por sempre estar ao meu lado, me iluminando e abençoando, e me proporcionando momentos de intensa felicidade e realização, como a conclusão deste trabalho.
\end{abstract}

Aos meus queridos pais, Amauri e Maria Helena, por todo amor, doação e confiança a mim oferecidos. $O$ apoio e o incentivo que sempre me proporcionaram, foram fundamentais para a realização do meu ideal. A vocês, exemplos de integridade e dignidade, dedico este trabalho.

Aos meus queridos irmãos, Janeysa, Lucyla e Rodrigo, pelo amor, amizade e companheirismo. A vocês, que sempre me apoiaram e participaram das minhas conquistas e vitórias, dedico este trabalho. 


\section{AGRADECO ESPECIALMENTE}

Aos meus familiares: minha avó Wanda, meus tios, tias e primos, pelo carinho e amizade. Eu sei que poderei sempre contar com o apoio de vocês.

À tia Irany e Cidinha, por me acolherem com tanto carinho durante a fase de preparação para a seleção do curso de Mestrado.

À Prof ${ }^{a}$ Dr $^{a}$ Mireile São Geraldo dos Santos Souza, Diretora da FAFEID, pelo estímulo constante, impulsionando-me desde a graduação para novas conquistas, em busca do meu crescimento pessoal e profissional. Toda minha admiração, respeito e amizade.

À Profa Dra Conceição Eunice Canuto, Professora Titular da Disciplina de Ortodontia da FAFEID, responsável pelo meu entusiasmo pela Ortodontia. Agradeço por guiar meus primeiros passos nesta especialidade, por acreditar em mim, me apoiar, motivar e viabilizar minha qualificação profissional. Todo meu respeito, amizade e gratidão.

Ao Rodney, pelos bons momentos compartilhados, e por ter me apoiado e impulsionado em busca do meu ideal.

Ao Rodrigo Cançado, por sua solicitude e disponibilidade, por ser meu grande companheiro durante a realização deste trabalho. Você é um exemplo de responsabilidade, de coragem e de força. 


\section{AGRADECO ESPECIALMENTE}

Ao Prof. Dr. Arnaldo Pinzan, pela orientação precisa deste trabalho, e pelos ensinamentos transmitidos durante todo o curso de Mestrado.

Ao Prof. Dr. Guilherme Janson, Coordenador do curso de Pós-Graduação em nível de Mestrado, na área de Ortodontia, pela dedicação, seriedade e firmeza com que conduziu o nosso curso, e pelas imprescindíveis lições transmitidas durante o curso de Mestrado.

Aos demais professores da Disciplina de Ortodontia da FOB - USP, Prof. Dr. Décio Rodrigues Martins, Prof. Dr. Renato Rodrigues de Almeida, Prof. Dr. José Fernando Castanha Henriques e Prof. Dr. Marcos Roberto de Freitas, pelos sábios ensinamentos e orientações oportunas transmitidos durante o curso de Mestrado. 


\section{AGRADECIMENTOS}

À Faculdade de Odontologia de Bauru - USP, representada pela sua Diretora Prof ${ }^{a}$ Dr $^{a}$ Maria Fidela de Lima Navarro.

À Comissão de Pós-Graduação da Faculdade de Odontologia de Bauru - USP, representada pelo seu Presidente, Prof. Dr. José Carlos Pereira.

Ao Prof. José Roberto Lauris, pelos sábios ensinamentos e disponibilidade na orientação da análise estatística desse trabalho.

Aos amigos do curso de Mestrado: Analu, Angela, Celso, Yuka, Dani, Karina Lima e Rodrigo, pela amizade, cumplicidade, e pelos bons momentos compartilhados.

Aos colegas do Mestrado "antigo": Adriana, Celinha, Dani Machado, Denise, Fábio, Fabrício, Fernanda, José Eduardo, José Norberto, Karina Freitas, Maria Fernanda, Rejane e Sandra, pela amizade e pelos conhecimentos transmitidos sempre que requisitados.

Aos colegas do Doutorado: Adriano, Ana Carla, Ana Cláudia, Dani Garib, Danilo, Fausto, Karina Cruz, Karyna Valle, Paulo e Renata, pelo apoio e ensinamentos transmitidos. 


\section{AGRADECIMENTOS}

Às Faculdades Federais Integradas de Diamantina - FAFEID, representadas pela Diretora-Geral Prof ${ }^{a}$ Dr $^{a}$ Mireile São Geraldo dos Santos Souza, base de minha formação profissional.

Aos Professores da FAFEID, pela competência, dedicação e amizade demonstradas durante a minha formação acadêmica, e pelo incentivo e apoio na minha qualificação profissional.

À amiga Sandra Maynart, pelos valiosos ensinamentos e pela criteriosa correção gramatical e ortográfica desse trabalho.

Aos amigos Cândida e Tatão, Prof ${ }^{a}$ Cleuma, Prof. Geraldo Walter, Prof. Carlos Augusto, Tio Augusto, Mene e Tê, pela confiança e auxílio no início do meu exercício profissional, e pelo apoio e incentivo quanto ao meu crescimento profissional.

Aos amigos Vânia, Espedito e Rayssa, pelo carinho com que me acolheram em Bauru, pela amizade, disponibilidade e atenção sempre dispensadas a mim.

Aos amigos da FUNDAEPE e da FAFEID, por torcerem por mim e vibrarem comigo em cada conquista. 


\section{AGRADECIMENTOS}

Ao Pe. Alessander, pelo apoio, amizade, pelos sábios conselhos e pelas orações a mim oferecidos.

Aos meus amigos do curso de Graduação, em especial Lu e Grace, pelo companheirismo, amizade e apoio a mim despendidos.

A Ana Paula e Rogério, pela amizade sincera, confiança, e por compartilharem comigo alegrias, tristezas e conquistas.

Aos demais amigos, pelo carinho e torcida de sempre.

Aos meus pacientes, que contribuíram muito para o meu crescimento profissional.

Aos funcionários da Disciplina de Ortodontia da FOB - USP: Cristina, Vera, Sérgio, Daniel, “tia” Maria e Fernando, pela amizade, atenção e presteza a mim dispensados.

Aos funcionários da Pós-Graduação e da Biblioteca, pela disponibilidade e competência no exercício de suas funções, prestando-me auxílios importantes. 


\section{AGRADECIMENTOS}

À Coordenação de Aperfeiçoamento de Pessoal de Nível Superior (CAPES) pela concessão da bolsa de estudo.

A todos que estiveram envolvidos direta ou indiretamente na realização deste trabalho. 


\section{SUMÁRIO}

LISTA DE FIGURAS xiii

LISTA DE TABELAS. xiv

RESUMO xvi

1. INTRODUÇÃO. 1

2. REVISÃO DA LITERATURA 5

2.1. Desenvolvimento da dentição permanente.................................... 6

2.1.1. Mineralização dos dentes permanentes. 6

2.1.1.1. Seqüência e cronologia de mineralização dos dentes permanentes.

2.1.1.2. Relação entre o estágio de maturação dos dentes permanentes e o desenvolvimento somático

2.1.1.3. Fatores que influenciam $o$ desenvolvimento $e$ mineralização dos dentes permanentes

2.1.1.4. Os diferentes padrões de crescimento facial e o desenvolvimento dentário

2.1.1.5. Métodos para a avaliação dos estágios de mineralização dentária. 26

2.1.2. Erupção dos dentes permanentes 29

2.1.2.1. Relação entre a erupção dos dentes permanentes e o desenvolvimento somático.

2.1.2.2. Seqüência e cronologia de erupção dos dentes permanentes

2.1.2.3. Fatores gerais e locais que influenciam a erupção dos dentes permanentes..

2.1.2.3.1. Fatores de ordem geral 47

2.1.2.3.2. Fatores de ordem local. 55

2.1.3. Relação entre erupção e mineralização dos dentes permanentes.

3. PROPOSIÇÃO 64

4. MATERIAL E MÉTODOS 66

4.1. Material. 67

4.1.1. Seleção da amostra. 67 
4.1.2. Material para elaboração do traçado..................................... 68

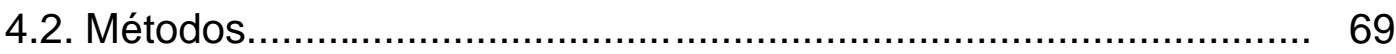

4.2.1. Classificação do padrão de crescimento facial.................... 69

4.2.1.1. Traçado anatômico.................................................. 69

4.2.1.2. Pontos de referência................................................... 69

4.2.1.3. Linhas e planos....................................................... 70

4.2.1.4. Grandezas cefalométricas esqueléticas...................... 70

4.2.2. Avaliação da maturação dentária........................................ 73

4.2.3. Avaliação da cronologia e seqüência de erupção dentária..... 80

4.2.4. Análise estatística............................................................ 81

4.2.4.1. Erro do método....................................................... 81

4.2.4.2. Testes estatísticos....................................................... 82

5. RESULTADOS

6. DISCUSSÃO

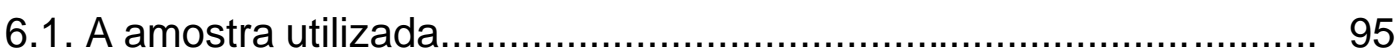

6.1.1. Telerradiografias em norma lateral..................................... 95

6.1.2. Radiografias panorâmicas................................................. 96

6.1.3. Modelos de gesso........................................................... 97

6.2. A metodologia empregada..................................................... 98

6.2.1. Classificação do tipo de padrão de crescimento facial............ 98

6.2.2. Avaliação da maturação dentária......................................... 99

6.2.3. Idade média de erupção dos dentes permanentes................ 100

6.2.4. Precisão da metodologia................................................... 102

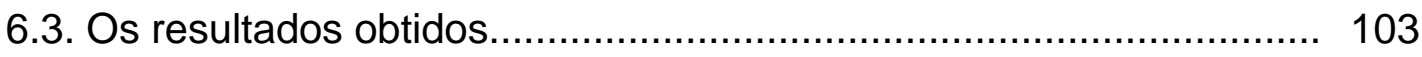

6.3.1. Resultados da análise cefalométrica.................................... 103

6.3.2. Resultados do estudo da maturação dentária........................ 103

6.3.3. Resultados da avaliação da erupção dentária........................ 105

6.4. Considerações clínicas.............................................................. 112

6.5. Sugestões para trabalhos futuros.............................................. 113

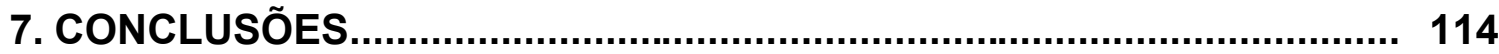

REFERÊNCIAS BIBLIOGRÁFICAS..................................................... 116

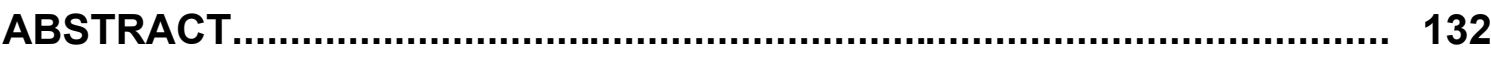

APÊNDICES 


\section{LISTA DE FIGURAS}

FIGURA 1 - Traçado anatômico com os pontos de referência, linhas e planos.

FIGURA 2 - Estágios de desenvolvimento dos dentes permanentes. Reproduzido de DEMIRJIAN; GOLDSTEIN; TANNER ${ }^{26}$ 


\section{LISTA DE TABELAS}

TABELA 1 - Número de pares de modelos avaliados em cada idade, na faixa etária dos 5 aos 13 anos de idade, distribuídos de acordo com o padrão de crescimento.

TABELA 2 - Escores de maturidade correspondentes aos estágios de desenvolvimento dos dentes permanentes, entre os gêneros ${ }^{28} . .77$

TABELA 3 - Conversão do escore de maturidade dentária em idade dentária (baseada nos 7 dentes permanentes inferiores do lado esquerdo) para o gênero masculino ${ }^{28}$

TABELA 4 - Conversão do escore de maturidade em idade dentária (baseada nos 7 dentes permanentes inferiores do lado esquerdo) para o gênero feminino ${ }^{28}$

TABELA 5 - Análise do erro intra-examinador. Apresentação dos erros casuais (Dahlberg), das médias, dos desvios padrão e nível de significância estatística dos erros sistemáticos (teste t pareado), entre os traçados cefalométricos repetidos.

TABELA 6 - Análise do erro intra-examinador. Apresentação do erro casual (Dahlberg), das médias, dos desvios padrão e nível de significância estatística do erro sistemático entre as avaliações das idades dentárias.

TABELA 7 - Resultados do teste $t$ independente entre as variáveis cefalométricas dos grupos Vertical e Horizontal.

TABELA 8 - Resultados do teste $t$ independente entre a idade dentária dos grupos Vertical e horizontal.

TABELA 9 - Resultados do teste t independente entre a idade cronológica e a idade dentária nos grupos Vertical e Horizontal.

TABELA 10 - Idade média de erupção, desvio padrão e erro padrão de cada dente permanente nos grupos Vertical e Horizontal e o nível de significância estatística quando aplicado o teste $t$ independente entre os grupos. 
TABELA 11 - Idade média de erupção, desvio padrão e erro padrão de cada dente permanente, nos gêneros masculino e feminino, no grupo Vertical e o nível de significância estatística quando aplicado o teste tindependente entre os gêneros

TABELA 12 - Idade média de erupção, desvio padrão e erro padrão de cada dente permanente, nos gêneros masculino e feminino, no grupo Horizontal e o nível de significância estatística quando aplicado o teste $t$ independente entre os gêneros

TABELA 13 - Idade média de erupção, desvio padrão e erro padrão de cada dente permanente dos jovens do gênero masculino nos grupos Vertical e Horizontal e o nível de significância estatística quando aplicado o teste $t$ independente entre os grupos

TABELA 14 - Idade média de erupção, desvio padrão e erro padrão de cada dente permanente das jovens do gênero feminino nos grupos Vertical e Horizontal e o nível de significância estatística quando aplicado o teste $t$ independente entre os grupos

TABELA 15 - Nível de significância estatística (p) quando aplicado o teste t independente entre as idades médias de erupção dos dentes permanentes dos lados direito e esquerdo no grupo Vertical...... 92

TABELA 16 - Nível de significância estatística (p) quando aplicado o teste t independente entre as idades médias de erupção dos dentes permanentes dos lados direito e esquerdo no grupo Horizontal.. 92

TABELA 17 - Nível de significância estatística (p) quando aplicado o teste t independente entre as idades médias de erupção dos dentes permanentes dos arcos superior e inferior no grupo Vertical....... 93

TABELA 18 - Nível de significância estatística (p) quando aplicado o teste t independente entre as idades médias de erupção dos dentes permanentes dos arcos superior e inferior no grupo Horizontal... 93

TABELA 19 - Seqüência média de erupção dos dentes permanentes para os arcos superior e inferior nos grupos Vertical e Horizontal. 
Resumo 


\section{RESUMO}

O objetivo desse estudo foi comparar a maturação e idade média de erupção dos dentes permanentes, em jovens leucodermas com padrões de crescimento vertical e horizontal. Para tanto, foram selecionadas telerradiografias em norma lateral de 111 jovens, a fim de classificá-los quanto ao tipo de padrão de crescimento facial. Uma vez realizada esta classificação, foram selecionados os 30 jovens que apresentaram o maior predomínio do vetor de crescimento vertical ( 15 do gênero masculino e 15 do feminino) e os 30 jovens que apresentaram o maior predomínio do vetor de crescimento horizontal (15 do gênero masculino e 15 do feminino), constituindo assim, os grupos Vertical e Horizontal, respectivamente. Selecionourse as radiografias panorâmicas desses 60 jovens, todas obtidas aos 8 anos de idade (a idade média do Grupo Vertical foi 8,5067 e do Grupo Horizontal 8,4800), para avaliar a maturação dos dentes permanentes, expressa em idade dentária, pelo método proposto por DEMIRJIAN; GOLDSTEIN; TANNER (1973). Da amostra total de 111 jovens, previamente classificados de acordo com o padrão de crescimento facial, selecionourse 533 pares de modelo de gesso de 97 jovens, na faixa etária dos 5 aos 13 anos de idade, para a avaliação da idade média de erupção dos dentes permanentes. Esses modelos de gesso foram distribuídos em dois grupos (Vertical e Horizontal). A idade média de erupção dos dentes permanentes foi obtida pelo método de Karber. As comparações entre os grupos foram realizadas por meio do teste $t$ independente. Os resultados demonstraram que houve diferença estatisticamente significante entre a idade dentária dos grupos Vertical e Horizontal. O Grupo Vertical apresentou uma idade dentária mais avançada quando comparado ao Grupo Horizontal. Em relação à idade média de erupção, dos 28 dentes permanentes considerados (exceção dos terceiros molares), apenas os pré-molares superiores do lado esquerdo apresentaram diferença estatisticamente significante entre os grupos Vertical e Horizontal. Assim, pode-se esperar que jovens com padrão de crescimento vertical apresentem uma maturação dentária mais precoce do que aqueles com padrão de crescimento horizontal. 
1. Introdução 


\section{INTRODUÇÃO}

O estudo da maturação e da erupção dentária humana é de grande importância, principalmente para as disciplinas de Odontopediatria, Ortodontia Preventiva e Interceptora e Odontologia Legal.

Para a Ortodontia Preventiva e Interceptora, tornam-se mais importantes a seqüência e o lugar da erupção dos dentes permanentes, pois, uma determinada seqüência eruptiva oferece oportunidade ideal para que todos os dentes venham a ocupar o lugar adequado nos respectivos arcos dentários. As más oclusões associam-se mais æ̀s alterações de ordem de erupção, do que æ̀े variações de cronologia eruptiva.

FERREIRA ${ }^{30}$ define a erupção dentária como um complexo fenômeno resultante de causas variadas, que faz com que 0 dente, ainda incompletamente formado, migre do interior dos ossos basais para a cavidade bucal. Segundo esse autor, o mecanismo da erupção pode ser estudado tendo-se em conta três períodos que se sucedem e que são interdependentes:

. período inicial ou pré-eruptivo;

. período de erupção propriamente dita;

- período pós-eruptivo.

O período inicial ou pré-eruptivo inicia-se com a diferenciação dos germes dos dentes ainda na vida intra-uterina e se estende até o contato da borda incisal com o cório ou derma da mucosa buca|30. Entretanto, GUEDESPINTO39 considera que ao término desse período, a coroa dentária encontrase completamente formada, sem que o dente se movimente em direção ao plano oclusal e alcance a mucosa bucal.

O período de erupção propriamente dito (fase eruptiva) está compreendido entre o momento em que se dá o rompimento do epitélio bucal e o conseqüente aparecimento do dente na cavidade bucal, até o estabelecimento do contato dos dentes de um arco com os do arco 
antagonista ${ }^{30}$. Paralelamente, GUEDES-PINTO39 considera que este período inicia-se com a completa formação da coroa dentária e se estende até o dente alcançar o plano oclusal. Portanto, durante este período, o dente continua adaptando a sua posição dentro dos ossos basais em crescimento e move-se em direção ao plano oclusal. Esta fase eruptiva é intra e extra-óssea.

O período pós-eruptivo inicia-se quando o dente entra em oclusão e segue por toda a vida ou termina com a remoção do mesmo. Este período corresponde à fase passiva da erupção dentária. Os movimentos dentários pós-eruptivos são aqueles que mantêm a posição do dente irrompido enquanto a base óssea continua a crescer, e aqueles que compensam os desgastes oclusais e proximais ${ }^{30}$.

Fatores tanto de ordem geral como raça, gênero, presença de alguma alteração, desordem, síndrome (por exemplo, a síndrome de Down), ou distúrbios endócrinos (por exemplo, a alteração da função da tireóide), quanto de ordem local (como por exemplo, a anquilose de molares decíduos, a retenção prolongada de dentes decíduos, a presença de cistos, abscessos na região do dente permanente em desenvolvimento) podem alterar a cronologia e a seqüência de erupção dos dentes permanentes.

Assim, torna-se importante o conhecimento das idades médias de mineralização e erupção dos dentes permanentes, para que os possíveis desvios dos padrões normais sejam diagnosticados e interceptados. Entretanto, as tabelas cronológicas, quase sempre não concordantes entre si, mostram-se muitas vezes inadequadas para a orientação da avaliação dos padrões de normalidade referente à erupção dos dentes. Tratando-se de tabelas elaboradas em diferentes regiões e com indivíduos que vivem em condições diversas no meio geográfico, torna-se provável a influência dessas condições nas variações apresentadas na cronologia eruptiva117. Deve-se atentar ao fato de que indivíduos de grupos raciais e níveis sócio-econômicos distintos, apresentam sua maturação em diferentes estágios, havendo consideráveis variações genéticas no desenvolvimento dentário ${ }^{16}$, sendo, 
portanto, necessário o estabelecimento de padrões de cronologia e seqüência de erupção dentária para as diferentes populações ${ }^{15}$.

Muitos estudos foram realizados $16,21,65,70,100,104,109$ no intuito de ampliar os conhecimentos desse vasto e importante assunto, não apenas em relação à cronologia e seqüência de erupção, ou a época de mineralização, como também no sentido de utilizar a idade dentária como auxiliar no diagnóstico dos distúrbios do crescimento e desenvolvimento físicos e na determinação da idade cronológica do jovem, como um indicador do desenvolvimento, baseada nos estágios de mineralização dentária ${ }^{125}$. Procura-se também correlacionar a época de mineralização dos dentes permanentes com a época ideal para o início das terapias ortodônticas.

$\mathrm{Na}$ literatura consultada, não se observou estudos a respeito do desenvolvimento dentário nos diferentes tipos faciais, com exceção do estudo realizado por JANSON et al. ${ }^{50}$, em 1998, onde se observou que os indivíduos portadores de uma mordida aberta esquelética, associada a uma altura facial ântero-inferior aumentada, apresentaram uma leve tendência de precocidade na maturação dentária em relação aos indivíduos portadores de sobremordida profunda esquelética, associada a uma altura facial ântero-inferior diminuída. Assim, decidiu-se realizar essa pesquisa com a inalidade de confirmar essa tendência e investigar a relação dos diferentes padrões de crescimento facial com a maturação e erupção dos dentes permanentes, uma vez que já foi demonstrada uma estreita relação entre esses dois fenômenos do desenvolvimento dentário27. 


\section{Revisão da Literatura}




\section{REVISÃO DA LITERATURA}

Objetivando uma melhor compreensão, a revisão da literatura foi desenvolvida de maneira a oferecer informações quanto ao desenvolvimento da dentição permanente, enfocando separadamente a mineralização e a erupção dos dentes permanentes, apesar de haver uma íntima relação entre esses dois processos. Com relação à mineralização dentária, foram revisadas sua seqüência e cronologia, a relação entre o estágio de maturação dos dentes permanentes e o desenvolvimento somático, os fatores que influenciam o desenvolvimento e mineralização dos dentes permanentes, os diferentes padrões de crescimento facial e suas possíveis relações com 0 desenvolvimento dentário e os principais métodos para se avaliar os estágios de mineralização dentária. Ao revisar a erupção dentária, abordou-se a relação entre a erupção dos dentes permanentes e o desenvolvimento somático, a seqüência e cronologia da mesma, além dos fatores gerais e locais que influenciam a erupção desses dentes permanentes.

\subsection{Desenvolvimento da dentição permanente}

O desenvolvimento da dentição permanente consiste em um processo complexo, que se inicia com a formação dentária (odontogênese), desde o estabelecimento do folículo dentário, até a completa formação destes dentes e o desempenho de suas funções, que continua ao longo de toda a vida39.

\subsubsection{Mineralização dos dentes permanentes}

Com o objetivo de estudar o dimorfismo de gênero na mineralização dentária, GARN et al. ${ }^{36}$, em 1958, realizaram um estudo longitudinal com 255 pacientes por um período de 18 anos, utilizando radiografias oblíquas de mandíbula de jovens leucodermas. Em geral, as jovens do gênero feminino apresentaram uma precocidade na mineralização dos seus dentes permanentes em relação aos jovens do gênero masculino. O menor dimorfismo de gênero foi obtido em idades mais precoces, notando-se uma divergência marcante entre os gêneros (maior dimorfismo de gênero) com o passar dos 
anos. O percentual de dimorfismo de gênero na cronologia de mineralização dentária (em torno de 3\% de precocidade para o gênero feminino) e na erupção dentária (em torno de $5 \%$ de precocidade para o gênero feminino) apresenta-se consideravelmente menor que o percentual encontrado entre os gêneros em relação ao desenvolvimento ósseo (10 a 25\%). Os resultados revelaram a necessidade do estabelecimento de normas quantitativas diferentes para os gêneros quando da avaliação do desenvolvimento dentário.

Em 1969, SOUZA-FREITAS107 estudou a correlação entre a idade cronológica e a idade dentária, esta última determinada por meio de quatro principais tabelas americanas, a saber: a de LOGAN; KRONFELD68, elaborada em 1933 e modificada por McCALL e SCHOUR75 em 1944, a de GARN et al. ${ }^{35}$, a de NOLLA 87 e a de MOORREES et al. ${ }^{80}$. A amostra consistiu de 420 jovens leucodermas brasileiros de terceira geração (descendentes de avós portugueses, italianos e espanhóis), de ambos os gêneros, com idade cronológica compreendida entre 48 a 215 meses, do perímetro urbano e suburbano da cidade de Bauru. O autor concluiu que a amostra estudada apresentava um desenvolvimento dentário precoce nas menores idades, ocorrendo o inverso em idades mais avançadas, em relação æ̀s amostras utilizadas na confecção das tabelas empregadas.

Buscando investigar a existência de dimorfismo de gênero no desenvolvimento dentário e na emergência dos dentes na cavidade bucal, DEMIRJIAN; LEVESQUE27 (1980) avaliaram 5437 radiografias panorâmicas em uma amostra bastante homogênea de jovens franco-canadenses, com idades entre 2 anos e meio e 19 anos. Até os 6 anos de idade, não houve diferença estatisticamente significante entre os gêneros quando se avaliou a cronologia do desenvolvimento dentário, ao contrário do que ocorreu em idades mais avançadas, em que os indivíduos do gênero feminino estavam sempre em um estágio de desenvolvimento dentário mais avançado. Quando se avaliou a existência de correlação entre o desenvolvimento dentário e a erupção dos dentes permanentes, houve uma forte correlação positiva entre a emergência dos dentes permanentes na cavidade bucal e os seus estágios de mineralização. 
SOUZA-FREITAS et al. ${ }^{109}$, em 1990, examinaram 2130 escolares de ambos os gêneros da região de Bauru, com idades variando de 3 a 11 anos e desenvolveram as tabelas da evolução dentária para cada dente, considerando a maxila, mandíbula e gênero. Os resultados foram comparados com outros estudos nacionais e internacionais, a fim de determinar o grau de variabilidade e confiabilidade destas tabelas. As diferenças nas idades médias das diferentes fases de formação dos dentes encontradas entre os gêneros confirmaram que o gênero feminino apresenta-se precoce, tanto na cronologia da mineralização como da erupção dentária, ratificando a necessidade de normas quantitativas específicas para cada gênero. Observourse que as diferenças foram menores para as fases iniciais do desenvolvimento dentário, e aumentaram gradativamente, chegando a uma precocidade de $10 \%$ em relação ao gênero masculino nas faixas etárias de 11 a 14 anos, correspondentes à puberdade.

Com o objetivo de avaliar os estágios de desenvolvimento dos dentes permanentes, CARVALHO; CARVALHO; SANTOS PINTO ${ }^{16}$, no mesmo ano, examinaram as radiografias panorâmicas de 156 jovens dos gêneros masculino e feminino, com idades cronológicas variando entre 84 e 131 meses, da cidade de Araçatuba e região circunvizinha, além de registrarem suas massas corporais e alturas. Para a avaliação do desenvolvimento dentário, os autores se basearam nos métodos propostos por DEMIRJIAN; GOLDSTEIN; TANNER ${ }^{26}$ e SOUZA-FREITAS et al. ${ }^{109}$. Assim, estimaram suas idades dentárias e confrontaram-nas com suas idades cronológicas. Pelos resultados obtidos, observourse que as jovens do gênero feminino apresentaram: uma precocidade na cronologia de formação dos dentes permanentes; os valores médios de idade dentária maiores do que os jovens do gênero masculino da mesma idade cronológica; os valores médios de idade dentária superiores aos de suas idades cronológicas.

Em 1991, BURDI; MOYERS12 ressaltaram que em relação à mineralização dos dentes permanentes, deve-se sempre ter em mente os seguintes estágios de mineralização de NOLLA 87 : o estágio 2 e o estágio 6, que correspondem respectivamente ao início da mineralização do dente e à 
época em que os dentes iniciam seus movimentos eruptivos. Segundo os autores, o gênero feminino apresenta-se mais adiantado na mineralização dos dentes permanentes que o gênero masculino em cada estágio de mineralização. As diferenças entre os gêneros para a mineralização dos dentes apresentam-se menores que para o desenvolvimento ósseo. Os autores acreditam que a variabilidade na mineralização dos dentes permanentes é muito maior do que em geral se supõe, provavelmente porque as "normas" mais populares do desenvolvimento dentário se originam de amostras muito pequenas. A variabilidade do desenvolvimento dentário é semelhante à da erupção, da maturação sexual e de outros indicadores de crescimento similares.

Visando investigar a presença de diferenças na idade de maturação dentária entre jovens tratados ortodonticamente na década de 70 e na década de 90, NADLER ${ }^{81}$, em 1998, estudou uma amostra de 300 pacientes caucasianos, com idades entre 8 e 14 anos, sendo que 150 destes pacientes foram tratados na década de 70 e 150 na década de 90. Calculourse a porcentagem de mineralização dos caninos inferiores de acordo com o método proposto por DEMIRJIAN; GOLDSTEIN; TANNER26 em 1973, que classificou o desenvolvimento dentário em oito estágios distintos, de $\mathrm{A}$ até $\mathrm{H}$. A comparação foi feita utilizando-se o estágio $G$ do referido método entre os pacientes da amostra. Observourse uma redução na idade dentária de 1,21 ano para o gênero masculino e 1,52 ano para o gênero feminino, e quando se avaliou a amostra sem distinção entre os gêneros, a redução foi de 1,4 ano.

No mesmo ano, FERREIRA 30 ressaltou a importância do conhecimento dos estágios de desenvolvimento de NOLLA87, pois, pode-se acelerar ou retardar o processo de erupção dos dentes permanentes por meio da extração de seus antecessores decíduos, na época adequada. Além disso, o estágio médio de mineralização dos dentes em diferentes idades, pode determinar um índice mais preciso de idade dentária do que a erupção dos mesmos.

Com o propósito de comparar a idade dentária com a idade cronológica em um grupo de jovens nascidos há 200 anos atrás e um outro grupo de jovens 
britânicos contemporâneos, LIVERSIDGE62, em 1999, avaliou a maturação dentária em 15 esqueletos intactos de indivíduos dos séculos passado e 30 jovens nascidos em épocas atuais. A diferença entre a idade dentária e a idade cronológica para ambos os grupos não foi estatisticamente significante, sugerindo um padrão de maturação dentária similar, que permanece por mais de 200 anos nos jovens britânicos.

Ressaltando a importância da compreensão do desenvolvimento da dentadura mista em relação ao manejo adequado dos espaços presentes no arco e na decisão de como e quando interceptar uma má oclusão se o apinhamento for detectado em idades mais precoces, NGAN; ALKIRE; FIELDS JR.85, em 1999, afirmaram que o programa de extração seriada está indicado para aqueles casos em que há uma grande discrepância entre o tamanho dentário e o tamanho do osso basal, e quando da execução desta terapêutica, torna-se essencial que o profissional conheça profundamente os diversos estágios de mineralização dos dentes permanentes, para que se alcancem resultados satisfatórios com o tratamento.

Com o objetivo de contribuir para o melhor entendimento do desequilíbrio na formação radicular, ARRUDA et al. ${ }^{3}$, em 2000, realizaram uma revisão da literatura sobre a fisiologia de erupção normal, bem como sobre a possível causa do desequilíbrio no tempo de formação da raiz e da alteração fisiológica, que acontece no processo de erupção. Durante o início da formação do dente, o germe dentário aumenta concentricamente em todas as direções. Ele pode mudar sua posição com o crescimento do osso alveolar, mas não há movimento eruptivo. O dente inicia a sua erupção quando a formação da coroa está completa e o desenvolvimento da raiz está começando (entre os estágios 5 e 6 de Nolla). Tem sido observado clinicamente que o atraso na formação dos dentes permanentes é um fenômeno que ocorre mais freqüentemente em pré-molares. O desequilíbrio na formação dentária é provavelmente causado pelo retardo da sua mineralização. $O$ atraso na mineralização dos primeiros e segundos pré-molares aparecem com igual freqüência em jovens do gênero feminino e masculino. A incidência na maxila é maior do que na mandíbula. $A$ impacção do dente não impede a rizogênese, tendo em vista as observações 
radiográficas da formação de raízes de dentes impactados. No âmbito do diagnóstico e do planejamento terapêutico ortodôntico, o atraso na rizogênese de pré-molares, muitas vezes não identificado clinicamente, detém um papel importante. O retardo no desenvolvimento, com conseqüente atraso na troca de dentes, não raramente prolonga o tratamento, bem como pode ser fator etiológico de uma má oclusão.

CORDEIRO et al.21, em 2000, desenvolveram um estudo com o intuito de observar os estágios de mineralização de pré-molares e molares permanentes, bem como verificar a situação de erupção clínica em que esses dentes se encontravam em uma comunidade rural da cidade de Araraquara. Os autores concluíram que tanto a mineralização, como a erupção dos dentes dos jovens da zona rural ocorreram de maneira harmoniosa e uniforme, não apresentando nenhuma alteração significante.

BECKER; CHAUSHU4, em 2000, investigaram a suposição baseada em observações clínicas, de que os pacientes que apresentam caninos ectópicos palatinamente apresentam um atraso no desenvolvimento dentário. O grupo experimental consistiu de 55 radiografias panorâmicas de pacientes com caninos superiores deslocados palatinamente e de 47 pacientes com caninos deslocados vestibularmente. Comparourse o grupo experimental com um grupo controle de 57 pacientes, com caninos posicionados adequadamente. Aproximadamente a metade dos pacientes com deslocamento palatino exibiu um desenvolvimento dentário significantemente atrasado, enquanto que o desenvolvimento dentário dos demais pacientes apresentourse normal. 0 deslocamento vestibular não se apresentou associado com o atraso no desenvolvimento dentário, e as variações dos valores das idades dentárias foram semelhantes àquelas do grupo controle. Os resultados validaram a idéia de que há etiologias diferentes para as ectopias palatina versus vestibular dos caninos superiores. 


\subsubsection{Seqüência e cronologia de mineralização dos dentes permanentes}

Observando a cronologia de mineralização e erupção dos caninos permanentes inferiores e dos pré-molares inferiores, BRADLEY10, em 1961, objetivou determinar se há alguma relação desta com o apinhamento dos dentes inferiores permanentes. Para isto, avaliou uma média de sete radiografias laterais do lado direito da mandíbula e um modelo de estudo com todos os dentes permanentes inferiores irrompidos anteriores aos primeiros molares, para cada um dos 89 jovens do gênero masculino examinados, com idades variando entre 3 a 18 anos. $O$ canino e os pré-molares iniciaram a erupção quando suas coroas estavam completas e alcançaram o plano oclusal antes de suas raízes estarem completas. O canino e o primeiro pré-molar iniciaram e completaram a erupção aproximadamente ao mesmo tempo, seguidos pelo segundo pré-molar. $O$ aumento do apinhamento nos dentes permanentes inferiores apresentou uma baixa, porém significante correlação com o retardo das fases iniciais de erupção do canino e com o retardo da mineralização do segundo pré-molar, seguido por uma aceleração das fases iniciais de sua erupção. A variação individual foi tão grande que se torna impraticável predizer a existência de apinhamento a partir da mineralização ou época de erupção dentária, ou a influência que apinhamentos moderados exercem sobre a época de erupção dos dentes permanentes.

Em sua obra publicada em 1965, GRABER 38 relatou que quando o feto encontra-se pronto para nascer, as coroas dos incisivos centrais decíduos superiores e inferiores encontram-se completamente formadas. Suas raízes estão começando o desenvolvimento. Lingualmente a estes dentes se encontram os germes dos dentes permanentes. Os primeiros molares permanentes apresentam o início da mineralização. Ao nascimento, a maxila e a mandíbula apresentam cavidades ósseas alojando dentes em diversos estágios de desenvolvimento. Nesta época, inicia-se a mineralização das coroas dos incisivos centrais superiores; o primeiro molar permanente está se desenvolvendo e iniciando a mineralização. Aos 2 anos de idade, está ocorrendo a mineralização dos dentes permanentes anteriores aos primeiros 
molares. Em algumas crianças pode-se observar as criptas em desenvolvimento dos segundos molares permanentes. Aos 3 anos, as coroas dos primeiros molares permanentes encontram-se completamente formadas e suas raízes estão começando a se formar. Dos 5 aos 6 anos, exatamente antes da esfoliação dos incisivos decíduos, há mais dentes nos ossos basais do que em qualquer outro momento. O primeiro molar permanente irrompe entre 6 e 7 anos. Normalmente, o incisivo central inferior irrompe antes do superior. Entre os 8 e 9 anos, os incisivos laterais superiores e inferiores irrompem por um estreito percurso para alcançar seus lugares adequados. Por volta dos 9 a 10 anos, todos os dentes permanentes, exceto os terceiros molares, completaram a formação de suas coroas e a aposição de esmalte. As jovens do gênero feminino apresentam-se de um ano a um ano e meio mais adiantadas que os jovens do gênero masculino.

Em 1977, TROTTER; HIXON. MACDONALD118 avaliaram radiograficamente os estágios de desenvolvimento e o tamanho dos dentes em Macaca mulatta. O macaco résus (Macaca mulatta), mais do que qualquer outro primata, é utilizado com um substituto para o homem em investigações científicas. A amostra transversal consistiu de 151 crânios de Macaca mulatta de idades conhecidas, sendo 43 crânios de fetos e 108 pós-natais, e foi distribuída de acordo com o gênero e idade. Os primeiros dentes permanentes que começaram e completaram seu desenvolvimento foram os primeiros molares inferiores. Os dentes decíduos apresentaram um menor estágio de desenvolvimento ao irromperem do que os dentes permanentes. Em ambas as dentições, raramente os dentes superiores apresentaram-se em um estágio mais precoce de desenvolvimento do que os dentes inferiores correspondentes. Na época de esfoliação do dente decíduo, a coroa do sucessor permanente estava completa e a formação radicular já havia se iniciado. 


\subsubsection{Relação entre o estágio de maturação dos dentes permanentes e o desenvolvimento somático}

NANDA ${ }^{82}$, em 1960, realizou um estudo longitudinal onde observou que a comparação entre a idade em que a dentadura permanente se completou e a idade da velocidade máxima do surto de crescimento pubescente para os dois gêneros e a idade da menarca para as jovens do gênero feminino apresentou apenas uma pequena correlação. Sugeriu, entretanto, que as baixas correlações entre os atributos físicos estudados poderiam ser devido a um relacionamento não específico entre maturação dentária e a puberdade. $O$ nível de correlação entre o crescimento da face e o desenvolvimento da dentição se apresentou baixo. Este fato é de considerável importância no diagnóstico e plano de tratamento ortodôntico.

Com a finalidade de determinar a relação entre a época de erupção dos 28 dentes permanentes com os outros indicadores do crescimento e desenvolvimento pubescente e esquelético, bem como a correlação existente entre a maturidade somática e a presença dos dentes na cavidade bucal, HÄGG; TARANGER ${ }^{41}$, em 1984, avaliaram uma amostra longitudinal de 212 jovens suecos. Os resultados revelaram uma baixa correlação entre 0 desenvolvimento somático e dentário em ambos os gêneros. No entanto, houve uma diferença marcante entre os gêneros, sendo que no feminino houve uma correlação estatisticamente significante entre o desenvolvimento de toda a dentadura permanente e o desenvolvimento somático pubescente, ao passo que, no gênero masculino, o desenvolvimento dentário ocorreu quase sempre independente do desenvolvimento somático na puberdade. Além disso, não houve uma correlação positiva entre os diversos indicadores de desenvolvimento somático e o desenvolvimento dentário.

No ano seguinte, buscando avaliar a relação existente entre cinco eventos indicativos de maturidade fisiológica (a menarca, o pico de crescimento pubescente, $75 \%$ da maturidade esquelética, a visualização do osso sesamóide e $90 \%$ do desenvolvimento dentário) em uma amostra de 50 indivíduos do gênero feminino, DEMIRJIAN et al. ${ }^{24}$ observaram que a idade 
média de ocorrência dos eventos citados anteriormente diferiu significantemente. A menor variabilidade ocorreu entre a menarca e $90 \%$ do desenvolvimento dentário. $\mathrm{O}$ pico de crescimento pubescente, a menarca e $75 \%$ da maturidade esquelética apresentaram uma correlação estatisticamente significante. A idade da menarca apresentou uma correlação positiva com o pico de crescimento pubescente. A visualização do osso sesamóide apresentou uma correlação positiva com o alcance de $75 \%$ da maturidade esquelética. A idade em que as jovens atingiram $90 \%$ do desenvolvimento dentário não apresentou nenhuma relação significante com os outros indicadores de maturidade. Assim, os resultados sugerem que os mecanismos que controlam o desenvolvimento dentário apresentam-se independentes da maturidade somática ou sexual.

BURDI; MOYERS 12, em 1991, ressaltaram que a mineralização do dente se correlaciona de um modo geral com altura, peso, tipo de corpo e ossificação dos ossos do pulso, mas tais correlações raramente apresentam-se significantes; além do mais, sua utilidade clínica torna-se limitada.

A fim de avaliar e quantificar as diferenças entre dois grupos ortodônticos de regiões distintas dos EUA em relação às idades médias de mineralização e erupção dentária e avaliar também as idades esqueléticas por meio de radiografias de mão e punho com o objetivo de se comparar o desenvolvimento dentário com o esquelético, MAPPES; HARRIS; BEHRENTS70, em 1992, utilizaram radiografias panorâmicas e carpais de jovens leucodermas, com idades cronológicas variando entre 12 e 13 1/zanos. Os pré-molares e molares superiores apresentaram um desenvolvimento mais avançado em relação aos seus correspondentes inferiores. $O$ gênero feminino quase invariavelmente alcançou um dado estágio de formação à frente do masculino. As comparações estatísticas dos estágios de mineralização da coroa e raiz e da erupção do segundo molar apresentaram uma diferença considerável (18 a 24 meses) na cronologia média de desenvolvimento entre os pacientes ortodônticos leucodermas do grupo da região centro-sul (Tennessee) e o grupo da região centro-oeste (Ohio), sendo o grupo da região centro-sul comparativamente atrasado em todas as fases de formação e 
erupção testadas. Essas diferenças sugerem uma considerável variação interregional no período de crescimento. As conseqüências clínicas implicam em reconsiderar o uso nacional das normas convencionais (geralmente baseadas nos padrões da região nordeste dos EUA) da formação e erupção dentárias e modelos predictivos de crescimento facial para populações de regiões específicas. A cronologia de ossificação da mão e do punho foi estatisticamente semelhante entre os dois grupos estudados. Houve dimorfismo de gênero, justificando a grande variação observada. Os autores concluíram que há uma independência do desenvolvimento ósseo e dentário.

Em 1995, SO106 realizou um estudo com 102 indivíduos chineses do gênero feminino, com idade cronológica de 12 anos, a fim de avaliar a existência de correlação entre a maturidade sexual, estatura e peso corporal e maturidade dentária. Para estimar a maturidade sexual, considerou-se as características sexuais: idade de ocorrência da menarca, idade em que surgiram os primeiros pêlos pubianos, idade em que os pêlos axilares apareceram e o desenvolvimento dos seios. Os resultados revelaram que as jovens que apresentaram um desenvolvimento dentário mais avançado, apresentaram uma tendência de ter a menarca em idades mais precoces.

Com o objetivo de observar o relacionamento da idade óssea com os estágios de mineralização de molares e pré-molares, CORDEIRO et al. ${ }^{20}$, em 1997, interpretaram radiografias panorâmicas e carpais de 120 jovens de ambos os gêneros, na faixa etária compreendida entre 6 anos e 11 anos e 11 meses. Caso fosse encontrada uma íntima relação entre os dois eventos, os estágios de mineralização dos dentes permanentes poderiam ser utilizados mais efetivamente para estimar o desenvolvimento esquelético dos pacientes. Os autores observaram uma certa concordância entre a idade cronológica e a idade óssea e uma tendência linear crescente para as idades cronológicas estudadas, em ambos os gêneros.

Buscando estimar a idade cronológica de um indivíduo por meio do desenvolvimento e mineralização de seus dentes, SALIBA et al. ${ }^{100}$, em 1997, avaliaram 274 indivíduos brasileiros, leucodermas, de ambos os gêneros, nas 
faixas etárias de 6 a 14 anos, por meio de radiografias panorâmicas. Os autores concluíram que não apareceram grandes diferenças de mineralização entre os dentes, tanto superiores quanto inferiores, em ambos os gêneros, e entre o lado direito e esquerdo. Os dentes dos jovens do gênero feminino apresentaram um grau de mineralização mais precoce do que os do gênero masculino, em quase todos os dentes analisados. A análise de correlação permitiu aos autores calcular uma fórmula para a estimativa da idade cronológica do indivíduo, baseando-se nos dentes e no gênero.

Com o propósito de avaliar a previsibilidade dos padrões de maturação dentária, em jovens canadenses de origens não-francesas, do gênero masculino, utilizando as curvas de maturação desenvolvidas por DEMIRJIAN; GOLDSTEIN25 em 1976 em uma população canadense de origem francesa, LOEVY; GOLDBERG67, em 1999, analisaram radiografias cefalométricas obtidas durante um estudo longitudinal realizado entre 1930 e 1960. Dos 79 jovens estudados, $12(15,2 \%)$ iniciaram a maturação abaixo da média encontrada por DEMIRJIAN; GOLDSTEIN25 e assim, continuaram durante o processo de maturação. Sete $(8,9 \%)$ iniciaram o processo de maturação acima do valor médio da curva de DEMIRJIAN; GOLDSTEIN25 e continuaram dessa maneira durante esse processo. Os 60 jovens restantes $(75,9 \%)$ iniciaram abaixo da média da curva de DEMIRJIAN; GOLDSTEIN25 em uma idade precoce. Ao final do período do estudo, esses jovens completaram a maturação acima do valor médio. Assim, os autores concluíram que a mudança dos valores abaixo da média para aqueles acima da média foi considerada um fator importante no plano de tratamento. Os dados indicaram que há um risco considerável para o plano de tratamento realizado anteriormente à idade de 8 anos. O risco torna-se maior quando a criança apresenta menos de 6 anos de idade, devido às incertezas na previsão do crescimento.

Nesse mesmo ano, SILVA; BOLOGNESE104 realizaram um estudo visando avaliar se por meio do grau de mineralização do segundo pré-molar inferior poderia se determinar a idade esquelética, a idade cronológica e a idade dentária geral do jovem. Para isto, utilizaram 33 radiografias panorâmicas e 33 radiografias de mão e punho de 18 jovens do gênero masculino e 15 do 
gênero feminino. A análise dos resultados encontrados revelou que o grau de mineralização do segundo pré-molar inferior não pode ser utilizado como indicador clínico da ocorrência do surto de crescimento pubescente, em ambos os gêneros; a correlação entre o grau de mineralização do segundo pré-molar inferior e a idade cronológica não se apresentou significante no gênero masculino e no gênero feminino não ocorreu essa correlação. As correlações entre o grau de mineralização do segundo pré-molar inferior e as idades dentárias gerais obtidas pelos métodos de NOLLA 87 e de DEMIRJIAN; GOLDSTEIN; TANNER 26 , no gênero masculino, demonstraram ter uma forte significância e no gênero feminino, demonstraram uma fraca correlação.

ROSSI; AMORIM; PACHECO98, em 1999, realizaram um estudo com o objetivo de avaliar a existência de correlação entre os estágios de mineralização radicular dos segundos molares inferiores e a mineralização da região da articulação metacarpofalangeana do dedo polegar, principalmente o osso sesamóide e a epífise da falange proximal, a fim de facilitar a estimativa da época de ocorrência do surto de crescimento pubescente e do potencial de crescimento remanescente do paciente ortodôntico. Obtiveram radiografias intrabucais e do dedo polegar do lado esquerdo de 72 jovens do gênero feminino, na faixa etária entre 8 e 13 anos de idade, além de fichas clínicas com dados pessoais como altura, peso, idade cronológica e época de ocorrência da menarca. Os resultados mostraram que a maioria das jovens que se apresentavam nos estágios 6 e 7 de Nolla, ainda não apresentavam osso sesamóide e encontravam-se no início do surto de crescimento. As jovens no estágio 8 de Nolla apresentavam início de formação do sesamóide, encontravam-se próximas ao pico de velocidade de crescimento pubescente e ainda não haviam tido a menarca. As jovens nos estágios 9 e 10 de Nolla já apresentavam o osso sesamóide formado, encontravam-se além do pico de crescimento pubescente e em geral, não haviam tido a menarca. Com relação à curva do surto de crescimento pubescente, as jovens até o estágio 8 de Nolla se encontram na curva ascendente. Verificou-se a existência de correlação entre os estágios iniciais de mineralização radicular e o início do surto de crescimento pubescente, entre o estágio intermediário de formação radicular e 
o pico de crescimento pubescente e entre os estágios finais de mineralização radicular e o final do surto de crescimento pubescente.

\subsubsection{Fatores que influenciam o desenvolvimento e mineralização dos dentes permanentes}

No ano de1968, WEYMAN123 realizou uma revisão dos efeitos da irradiação no desenvolvimento dentário em pacientes portadores de tumor na região da face e relatou um caso clínico de um paciente que recebeu uma baixa taxa de irradiação, aos 5 meses de idade e os efeitos desta irradiação no desenvolvimento dentário por um período de 15 anos. Dentre os principais efeitos da irradiação no desenvolvimento dentário, o autor citou a anodontia total e/ou parcial, anomalias de tamanho e forma, atraso no desenvolvimento e mineralização dentária e comprometimento da estrutura radicular, tanto em seu aspecto morfológico, como funcional. Em alguns casos pode ocorrer também uma erupção precoce do dente, no entanto, com menor freqüência do que os efeitos acima relatados. O autor concluiu que o grau de prejuízo no desenvolvimento dentário causado pela irradiação depende de inúmeros fatores, dentre eles o estágio da histogênese dos dentes em desenvolvimento e a dose de irradiação merecem um destaque especial.

LOEVY65, em 1983, relatou que existem variações no desenvolvimento dentário para diferentes populações. Vários fatores podem estar envolvidos nestas variações, como a raça, a etnia e o nível sócio-econômico.

Buscando verificar a influência dos fluoretos no desenvolvimento dentário, ELBADRAWY28, em 1984, realizou um estudo com 167 jovens em idades entre 6 e 12 anos, de duas comunidades distintas que apresentavam níveis ótimo e sub-ótimo de flúor na água de abastecimento. Os resultados revelaram que não houve influência dos níveis de fluoretos no desenvolvimento dentário nos dois grupos considerados.

BURDI; MOYERS12 (1991) acreditam que as diferenças raciais e o padrão sócio-econômico exercem influência na mineralização dentária. 
Com o propósito de estudar comparativamente populações de duas cidades, sendo que uma possui água de abastecimento público fluoretada artificialmente e a outra não e investigar se há diferença quanto ao desequilíbrio entre rizólise e rizogênese e retenção prolongada de dentes decíduos nas regiões anatômicas de caninos e molares decíduos, GARDUCCI; LINO33, em 1992, avaliaram radiografias periapicais de 120 alunos de escolas públicas, na faixa etária de 9 a 14 anos de idade, de ambos os gêneros, leucodermas, com níveis sócio-econômicos semelhantes. Um grupo foi constituído por jovens que residiam em cidade com água de abastecimento público fluoretada artificialmente (Marília - SP). O outro, por jovens que residiam em cidade sem fluoretação na água de abastecimento público (Brodósqui - SP). Os autores concluíram que não houve diferenças estatisticamente significantes quanto aos fatores: desequilíbrio rizóliserizogênese e retenção prolongada de dentes decíduos.

No ano seguinte, WEIDE; PRAHL-ANDERSEN; BOSMAN ${ }^{122}$ avaliaram a formação dentária em pacientes com oligodontia. Os dados foram obtidos de 216 pacientes, de ambos os gêneros, com idade média de 11,3 anos (variando de 5 a 14 anos), sendo que 6 pacientes apresentavam displasia ectodérmica e 210 oligodontia isolada. O número médio de dentes ausentes foi de 10,7 para o gênero feminino e 11,7 para o masculino. O grupo controle consistiu de 443 jovens, de ambos os gêneros, com idades entre 4 e 14 anos, e apresentavam a dentadura permanente completa. Os resultados desse estudo mostraram uma grande variação individual na formação dos dentes em pacientes com oligodontia. Alguns desses pacientes apresentaram um forte atraso na formação dentária, enquanto outros mostraram uma formação dentária normal. A formação dentária para os indivíduos do grupo controle apresentou-se dentro da variação biológica normal. Portanto, a formação dentária de cada paciente com oligodontia deve ser examinada individualmente antes do início do tratamento. Houve um atraso na formação dentária nos pacientes com oligodontia quando comparados ao grupo controle. Este atraso foi mais marcante no gênero masculino do que no feminino. 
Avaliando a influência da exposição ao tabaco no atraso da formação dentária, KIESER; GROENEVELD; SILVA54, em 1996, examinaram 203 radiografias panorâmicas de crianças caucasianas com idades cronológicas entre 7 e 10 anos. As radiografias foram divididas em quatro grupos: um grupo controle em que nenhum dos pais apresentava o vício de fumar, um grupo em que apenas a mãe era fumante, um outro grupo em que apenas o pai fumava e finalmente, um grupo em que ambos os progenitores fumavam. Em cada grupo, a idade cronológica foi comparada com a idade dentária de cada indivíduo. Os resultados revelaram que não houve diferenças nas idades dentárias, quando se considerou o gênero. A maior discrepância entre a idade cronológica e a idade dentária foi observada no grupo em que ambos os progenitores apresentavam o vício de fumar. Neste grupo, observourse uma redução em torno de $35 \%$ na maturidade dentária.

No mesmo ano, SYMONS; TAVERNE115 relataram casos clínicos relacionados a distúrbios na formação e erupção dentária do segundo prémolar. As anomalias de formação e erupção dentária podem afetar o desenvolvimento da dentição e podem surgir durante os vários estágios de desenvolvimento dentário. Torna-se difícil determinar a extensão pela qual os fatores hereditários e ambientais influenciam o desenvolvimento normal e patológico dos dentes, pois, o desenvolvimento dentário é determinado geneticamente e interage com a dinâmica do seu ambiente local. O presente relato descreve uma família que demonstrava anomalias de forma e erupção do segundo pré-molar inferior. Todos os membros da família foram afetados em algum grau pelo papiloma vírus humano (HPV). Ao observar os segundos prémolares nos arcos dentários do pai e da mãe, percebeu-se a erupção ectópica com impacção e espaços consideráveis entre os primeiros e segundos prémolares. Examinourse também quatro filhos -3 jovens do gênero masculino, com idades de 15, 14 e 12 anos, e uma do gênero feminino com 11 anos de idade. As anomalias do segundo pré-molar observadas nos filhos incluíram: ausência œngênita, erupção ectópica com impacção, atraso na erupção e a presença de espaços. As anomalias associadas incluíram: ausência congênita de outros dentes permanentes e a presença de espaços. Assim, parece que o defeito na formação e erupção dos dentes é de origem genética, afetando tanto 
o gênero masculino quanto o feminino. Esta condição parece não estar associada com alguma síndrome e as lesões do HPV observadas em todos os membros da família não foram consideradas relacionadas aos defeitos dentários. Esta família demonstrou duas anomalias do segundo pré-molar inferior: ausência congênita e distúrbio na erupção dentária. A questão levantada pelo relato desses casos é se essas duas anomalias são herdadas como traços separados ou se a falha da erupção dentária é uma variação na expressão do mesmo fator genético que resulta em oligodontia.

Em 1997, HARUKI; KANOMI; SHIMONO43 relataram que nos pacientes portadores de má oclusão de Classe II e Classe III, a correção da relação molar é um dos aspectos mais importantes no tratamento ortodôntico e que a obtenção da relação molar de Classe I pode ser conseguida por meio de forças ortopédicas; estas forças apresentam-se mais efetivas quando aplicadas antes da erupção do segundo molar permanente. Assim, os autores visaram investigar as possíveis diferenças nos processos de mineralização e erupção dos segundos molares permanentes, nos pacientes portadores destes dois tipos de má oclusão e suas implicações clínicas. A amostra consistiu de 53 pacientes com idades entre 7 e 10 anos, sendo 27 jovens portadores de má oclusão de Classe II e 26 portadores de má oclusão de Classe III. Os resultados revelaram diferenças nos valores médios de mineralização dos segundos molares superiores entre os dois grupos da amostra. Entretanto, não houve diferença estatisticamente significante nos valores médios de mineralização entre os dois grupos, quando se avaliou os segundos molares inferiores. Também não houve diferença estatisticamente significante nos valores médios de mineralização dentária entre os gêneros, nos dois grupos considerados. Em relação à quantidade de erupção dos segundos molares, houve diferenças significantes. Para os segundos molares superiores, o estágio eruptivo se encontrava mais avançado em indivíduos com má oclusão de Classe II, e no arco inferior, os segundos molares apresentavam-se em um estágio eruptivo mais avançado em indivíduos com má oclusão de Classe III. Houve também uma correlação positiva entre o estágio de mineralização e a cronologia de erupção do segundo molar superior e o valor do ANB, ou seja, o segundo molar superior do paciente, que apresentava o maior valor de ANB 
apresentou também um estágio de mineralização mais avançado e a erupção na cavidade bucal mais precoce. A implicação clínica deste estudo consiste em se considerar a época de tratamento e os tipos de aparelho quando o paciente apresentar uma má oclusão esquelética, porque o desenvolvimento do segundo molar difere em pacientes com má oclusão de Classe II e Classe III de Angle.

No intuito de avaliar a incidência de anomalias craniofaciais e dentárias em indivíduos portadores da forma mais severa de osteogênese imperfeita, O'CONNELL; MARIN188, em 1999, avaliaram 40 pacientes com idades entre 1 e 17 anos. Os autores observaram o atraso no desenvolvimento dentário em $21 \%$ dos pacientes portadores de osteogênese imperfeita, e em $23 \%$ dos pacientes ocorreu uma precocidade deste desenvolvimento. Além disso, a erupção ectópica ocorreu em 13 pacientes.

Com o propósito de investigar a influência da raça no processo de formação dentária, MAKI et al. ${ }^{69}$, em 1999, realizaram um estudo com 650 indivíduos, sendo 245 americanos leucodermas, 202 chineses e 203 japoneses com idades variando entre 5 e 12 anos. Analisaram o desenvolvimento dos primeiros molares permanentes inferiores em radiografias panorâmicas. Os resultados revelaram que os indivíduos do gênero feminino apresentaram uma erupção mais precoce em todos os grupos raciais considerados e 0 desenvolvimento dentário, em indivíduos americanos leucodermas, esteve significantemente mais avançado do que nos chineses e japoneses. Os autores concluíram que a formação do primeiro molar inferior mostrou ser um excelente indicativo na determinação da idade cronológica, o que se justifica pelos valores de coeficientes de correlação elevados nos três grupos raciais estudados.

No ano seguinte, LEHTINEN et al.60 relataram que o crescimento facial em jovens com artrite reumatóide juvenil apresenta desvios consideráveis da normalidade (por exemplo, a mandíbula e a maxila apresentam-se reduzidas em tamanho) e que a idade esquelética desses pacientes pode estar ligeiramente avançada antes dos 10 anos de idade e retardada entre as idades 
de 10 e 15 anos. O propósito dessa pesquisa foi comparar a maturação dentária dos jovens portadores da artrite reumatóide juvenil com aquela dos jovens saudáveis. Os autores concluíram que tanto nos jovens portadores da artrite reumatóide juvenil como nos jovens saudáveis, a maturação dentária apresentou-se àfrente da idade cronológica. Além disso, a maturação dentária apresentou-se significantemente avançada nos jovens portadores da artrite reumatóide juvenil. Pode-se sugerir, com bastante cautela, que o avanço no desenvolvimento dentário nos jovens portadores de artrite reumatóide juvenil, em comparação com os jovens saudáveis, seja em parte um efeito do tratamento dessa desordem com cortisona, enquanto que a influência da desordem por si só ainda necessita ser elucidada.

\subsubsection{Os diferentes padrões de crescimento facial e 0 desenvolvimento dentário}

Com o propósito de examinar os padrões de desenvolvimento e crescimento facial em jovens que apresentavam faces com mordida aberta esquelética e sobremordida profunda esquelética, NANDA ${ }^{83}$, em 1988, avaliou longitudinalmente radiografias laterais de 16 jovens do gênero masculino e 16 do feminino, com idades variando entre 3 e 18 anos, selecionados com base na altura facial ântero-inferior. Dos 32 jovens, 16 apresentavam mordida aberta e 16 sobremordida profunda. Os jovens com mordida aberta e sobremordida profunda cresceram diferentemente. O grupo com sobremordida profunda caracterizou-se pelo aumento da altura facial ântero-superior, enquanto que o aumento da altura facial ântero-inferior foi observado no grupo de mordida aberta. As diferenças tipológicas extremas pareceram ocultar as características do crescimento que normalmente são atribuídas ao dimorfismo de gênero. A altura facial posterior e a altura do ramo não apresentaram diferença significante entre os jovens com mordida aberta e sobremordida profunda. $\mathrm{O}$ padrão de desenvolvimento em cada forma facial foi estabelecido em uma idade bastante precoce, iniciando antes da erupção dos primeiros molares permanentes e se estendendo até antes do surto do crescimento pubescente. As jovens do gênero feminino portadoras de mordida aberta apresentaram uma maior precocidade na época do surto de crescimento pubescente, seguidas 
pelas jovens do gênero feminino com sobremordida profunda, pelos jovens do gênero masculino com mordida aberta e finalmente pelos jovens do gênero masculino com sobremordida profunda. Os resultados encontrados apresentam uma relevância clínica para a época do tratamento ortodôntico, a duração do período de contenção, e a previsibilidade do relacionamento oclusal desde a dentadura mista até a idade adulta.

No ano seguinte, NANDA; ROWE84 realizaram uma análise longitudinal do crescimento craniofacial em jovens com mordida aberta e sobremordida profunda esqueléticas, caracterizados pela altura facial ântero-inferior proporcionalmente aumentada ou diminuída, a fim de determinar a diferença na época e velocidade de crescimento do esqueleto facial em relação ao surto de crescimento pubescente. A amostra se baseou em radiografias cefalométricas laterais seriadas de 16 jovens do gênero masculino e 16 do feminino, com idades variando dos 3 aos 20 anos. Estabeleceu-se o padrão facial desses jovens pelo menos três anos antes do surto de crescimento pubescente e não houve alteração durante o período da adolescência. Este estudo sugere que os padrões de desenvolvimento se estabelecem antes do surto de crescimento pubescente. Os jovens com mordida aberta apresentaram uma maturação mais precoce do que os jovens com sobremordida profunda. As diferenças morfológicas entre os grupos foram mantidas durante o surto de crescimento pubescente. Fortes influências dos padrões de desenvolvimento nas duas formas faciais mascararam o dimorfismo de gênero expressado em várias outras dimensões do corpo.

Uma vez que o surto de crescimento pubescente apresenta um grau de correlação com o desenvolvimento dentário98,106 e que indivíduos com mordida aberta esquelética e sobremordida profunda esquelética apresentam uma diferença no início do surto de crescimento pubescente na face ${ }^{83}$, JANSON et al. ${ }^{50}$, em 1998, desenvolveram uma pesquisa com o objetivo de investigar se havia diferença na maturação dentária entre indivíduos com idades cronológicas semelhantes e portadores de discrepâncias verticais (mordida aberta esquelética e sobremordida profunda esquelética). Os autores avaliaram as telerradiografias em norma lateral e radiografias panorâmicas de 40 
indivíduos leucodermas (20 do gênero feminino e 20 do masculino) com idade cronológica média de 9 anos e 2 meses. A amostra foi dividida em dois grupos de 20 indivíduos cada (10 do gênero masculino e 10 do gênero feminino). Os grupos caracterizaram-se por possuir indivíduos com mordida aberta associada a um aumento da altura facial ântero-inferior, ou com sobremordida profunda e uma altura facial ântero-inferior diminuída. Para determinar a maturação dentária de cada indivíduo, utilizourse o método proposto por DEMIRJIAN; GOLDSTEIN; TANNER ${ }^{26}$ no ano de 1973. As idades dentárias médias para os grupos com mordida aberta esquelética e sobremordida profunda esquelética foram, respectivamente, 120,48 e 114,00 meses. O tratamento estatístico dos dados demonstrou que esta diferença foi estatisticamente significante para $p<0,05$. Assim, os resultados sugerem que os indivíduos portadores de mordida aberta esquelética possuem uma ligeira tendência de apresentar uma maturação dentária mais avançada, quando comparados com indivíduos portadores de sobremordida profunda esquelética.

\subsubsection{Métodos para a avaliação dos estágios de mineralização dentária}

GARN et al.36, em 1958, ao estudarem o dimorfismo de gênero na mineralização dentária em um estudo longitudinal, utilizaram radiografias oblíquas de mandíbula de 255 jovens leucodermas. Os autores utilizaram a seguinte classificação para os diferentes estágios de mineralização: Estágio I presença da cripta; Estágio II - coroa completa e início da formação radicular; Estágio III - rompimento da margem óssea alveolar (início da erupção); Estágio IV - chegada ao nível oclusal; Estágio V - fechamento do ápice radicular. As jovens do gênero feminino apresentaram uma idade cronológica mais avançada do que os jovens do gênero masculino, quando os 5 diferentes estágios de mineralização e erupção foram atingidos.

Até 1960, o método normalmente utilizado para se avaliar a idade dentária consistia na observação da erupção dos dentes. Entretanto, a consideração da erupção se referia a apenas uma fase do desenvolvimento da dentição. A avaliação da mineralização (maturação) em diferentes idades 
forneceria um índice mais preciso para a determinação da idade dentária e contribuiria para o conceito do organismo como um todo. Assim, NOLLA ${ }^{87}$, em 1960, realizou um estudo longitudinal com o objetivo de desenvolver um método preciso para a avaliação do desenvolvimento da dentição permanente, por meio de radiografias extra e intrabucais seriadas de 25 jovens do gênero masculino e 25 do gênero feminino. $O$ desenvolvimento de cada dente foi avaliado e graduado em uma escala de 0 a 10. Esta escala é representada por uma série de desenhos, ilustrando os 10 estágios de desenvolvimento dos dentes permanentes observados radiograficamente. Os lados direito e esquerdo apresentaram uma equivalência nos estágios de desenvolvimento. A fim de se obter uma avaliação do desenvolvimento de um dente em particular, a radiografia é comparada o mais próximo possível com a figura correspondente. $\mathrm{O}$ primeiro sinal radiográfico do desenvolvimento dentário consiste na aparência de uma estrutura radiolúcida, quase circular no osso, designada como a cripta. O germe dentário encontra-se incluído dentro dessa cripta. A próxima alteração observada consiste de pequenos pontos triangulares radiopacos próximos ao limite interno da borda coronária da cripta. Nas radiografias anuais sucessivas, o aumento quantitativo da mineralização torna-se facilmente detectável. A completa formação do ápice radicular constitui o último estágio a ser observado radiograficamente no processo de maturação. Não se observou diferenças significantes entre os gêneros no período de tempo requerido para o desenvolvimento, entretanto, as jovens do gênero feminino iniciam e cessam o desenvolvimento dentário em uma idade mais precoce que os jovens do gênero masculino. Com raras exceções, não houve diferenças aparentes entre os gêneros na seqüência geral do desenvolvimento de cada dente. A diferença entre o desenvolvimento real e a média revela a quantidade de variação, que é conhecida como individualidade no desenvolvimento dentário. Pode-se utilizar a mineralização dentária como um critério para a determinação da idade dentária e idade fisiológica do paciente, ela fornece um índice de maturidade fisiológica dos dentes permanentes. $O$ conhecimento sobre a aceleração ou o retardo geral de mineralização dos dentes de um indivíduo torna-se importante para o ortodontista que deseja determinar o tempo de tratamento com base na idade fisiológica do paciente. 
Em 1967, GARN; ROHMANN; SILVERMAN37 propuseram a utilização de oito estágios de desenvolvimento para os dentes humanos, referenciados de $\mathrm{A}$ a $\mathrm{H}$, citados a seguir: A) primeira aparição do folículo; $\mathrm{B}$ ) desenvolvimento completo do folículo, sem mineralização da cúspide; C) início da mineralização da cúspide; D) mineralização da superfície coronária; E) extensão da raiz abaixo da coroa; F) maior desenvolvimento radicular; G) raiz completa exceto o ápice e H) fechamento do ápice.

No ano de 1973, DEMIRJIAN; GOLDSTEIN; TANNER26 propuseram um novo método para a estimativa da maturidade ou idade dentária por meio de radiografias panorâmicas e utilizando a imagem dos sete dentes permanentes inferiores do lado esquerdo. De acordo com este método proposto, atribui-se aos dentes oito estágios de desenvolvimento, classificados de $A$ até $H$, que vão desde a aparência dos primeiros pontos de mineralização até o completo fechamento do ápice radicular. Apesar deste método de estimativa da idade dentária ser considerado universal, os autores enfatizam a necessidade de individualização dos dados obtidos, de acordo com a população a ser estudada.

Conscientes de que a intimidade dos fenômenos determinantes do desenvolvimento é complexa, mas que estes podem ser expressos numericamente, por dados antropométricos; de que herança, constituição e ambiente são os grandes condicionadores do crescimento, o que recomenda estudos antropológicos e, finalmente, de que é característica biológica fundamental a variação do indivíduo dentro dos padrões regionais de crescimento, SOUZA-FREITAS; LOPES; DAMANTE111, em 1991, propuseram com esse estudo transversal a construir tabelas de evolução dentária, para ambos os gêneros. Para isto, 2.130 escolares kucodermas brasileiros, 1.065 de cada gênero, com idades variando de 3 a 18 anos, matriculados nas escolas públicas do perímetro urbano e suburbano de Bauru - SP foram examinados, pesados, medidos e radiografados uma única vez. Foram obtidas radiografias panorâmicas e periapicais pela técnica da bissetriz. Os estágios da formação dos dentes foram divididos em 9 fases com escores de 0 a 6 : fase 0 - ausência do folículo; fase 0,25 - fase do folículo com as primeiras evidências de 
mineralização das cúspides; fase 0,50 - metade da coroa dentária formada e mineralizada; fase 1,00 - coroa totalmente formada e mineralizada, com ou sem iniciação da formação radicular; fase 2,00 - raiz em formação, mas de tamanho inferior ao da coroa dentária; fase 3,00 - raiz em formação e com tamanho equivalente ao da coroa dentária; fase 4,00 - raiz em formação e de tamanho superior ao da coroa dentária e com ápice aberto e divergente; fase 5,00 - raiz em formação e com ápice arredondado e convergente; fase 6,00 - raiz e ápice radicular completos. Quando em dúvida sobre a identificação entre duas fases, optou-se pela mais baixa. Os autores ressaltaram que nenhuma das tabelas propostas sobre a cronologia de mineralização e erupção dos dentes permanentes pode ter aplicação indiscriminada a qualquer população. Logo, torna-se necessário estabelecer tabelas com valores aplicáveis a grupos populacionais definidos. Os dados obtidos para cada dente foram sumarizados, a fim de se obter o valor médio e o desvio padrão, em cada idade, considerando separadamente a maxila e a mandíbula e os gêneros masculino e feminino.

\subsubsection{Erupção dos dentes permanentes}

No ano de 1993, PINHEIRO; CASADO; ASSUNÇÃO93 apresentaram o tema erupção dentária, com a finalidade de observar e analisar o conceito discriminativo deste assunto (fisiológico ou patológico) que é transmitido à comunidade (pais e responsáveis), bem como analisar a clientela estudada e se o tempo de profissão interfere nesta concepção conceitual. $\mathrm{Na}$ avaliação das respostas de 50 médicos pediatras de Brasília a um questionário constituído de cinco questões, $88 \%$ responderam que a erupção dentária é um processo fisiológico e em algumas ocasiões pode acontecer ligeiro desconforto.

Buscando correlacionar o movimento para a mesial dos primeiros molares permanentes no arco inferior com a magnitude e direção de crescimento facial e com a erupção dentária, RICHARDSON96, em 1996, examinou cefalogramas de 22 pacientes do gênero masculino e 29 do feminino, com idades cronológicas compreendidas entre 13 e 18 anos. Realizou a análise de correlação para avaliar a relação entre o movimento para 
a mesial do primeiro molar permanente, a erupção dentária, e as alterações no comprimento mandibular, na altura facial anterior e na direção de crescimento. Os resultados indicaram, em média, um movimento para anterior dos primeiros molares em torno de 2,0 a 3,0 mm e uma quantidade de erupção variando entre 2,0 e 4,0 mm. Não se observou nenhuma relação entre o movimento para a anterior dos primeiros molares e a quantidade de erupção ou a magnitude e direção do crescimento facial.

Ainda nesse mesmo ano, MARKS; SCHROEDER71 realizaram uma revisão na literatura enfocando os mecanismos de erupção dentária. Os autores concluíram que no momento, a habilidade profissional de interferir nesse processo seletivamente e criteriosamente apresenta-se limitada e inclui o estímulo local pela extração do dente decíduo ou remoção cirúrgica do osso e facilitando a penetração mucosa pela incisão da gengiva.

Estudando a impacção de caninos superiores associada ao deslocamento palatino dos mesmos, JACOBS ${ }^{49}$, em 1996, relacionou a etiologia dessa impacção àpresença de incisivos laterais adjacentes anômalos ou ausentes, por não promover um guia adequado ao canino durante sua erupção.

WISE124, em 1998, considerou o estudo da biologia da erupção dentária como um campo de pesquisa fascinante, e ressaltou que além das aves e répteis que se libertam dos tecidos duros em que estão confinados, a erupção dentária é o único processo de desenvolvimento em que um tecido duro, o dente, deve libertar-se de sua cápsula, o osso alveolar, em que está inserido.

\subsubsection{Relação entre a erupção dos dentes permanentes e o desenvolvimento somático}

Com o intuito de avaliar a existência de correlação positiva entre a erupção dentária e a idade cronológica, BROOK; BARKER ${ }^{11}$, em 1972, estudaram 4873 indivíduos de 3 grupos étnicos diferentes e confirmaram a existência de uma forte correlação positiva entre a erupção de dentes 
permanentes e a idade cronológica do indivíduo em todos os grupos étnicos estudados. No entanto, ressaltaram a limitação deste método de predição da idade cronológica devido à grande variabilidade na seqüência e cronologia de erupção dos dentes permanentes.

SATAKE; SILVA ${ }^{101}$, em 1990, examinaram 254 crianças brasileiras com idades entre 4 e 8 anos de uma escola particular e de uma escola municipal periférica de um mesmo bairro, obtendo medidas antropométricas de estatura, peso e verificando a época de erupção dos primeiros molares permanentes, a fim de estudar a relação entre crescimento e desenvolvimento físico e erupção dentária. Os autores observaram que as crianças da escola particular apresentaram valores médios de estatura e peso maiores que os das escolas municipais periféricas, além de maiores percentagens de primeiros molares permanentes irrompidos em ambos os gêneros, em todas as idades e verificaram uma correlação positiva entre o crescimento e desenvolvimento físico e a erupção dentária.

Com o objetivo de avaliar a relação entre crescimento e erupção dentária, BOSCO; SILVA $7,9,8$ realizaram um estudo, dividido em três partes, publicadas separadamente nos anos de 1991 e 1992, onde examinaram 475 crianças do gênero masculino e 525 do feminino, com idades entre 5 e 8 anos, alunos de uma escola particular de Florianópolis/SC. Na primeira parte deste estudo, mediram o perímetro cefálico das crianças com o intuito de estudar o processo de crescimento físico. Observaram que, embora houvesse um aumento gradativo do perímetro cefálico com o aumento da idade em ambos os gêneros, esse aumento apresentourse bastante discreto. Na segunda parte deste estudo, verificaram as porcentagens de primeiros molares, incisivos centrais e laterais permanentes superiores e inferiores irrompidos, com o propósito de verificar o comportamento da erupção desses dentes em relação ふ̀s variáveis idade e gênero, lados direito e esquerdo e arcos superior e inferior. Observaram que as porcentagens de dentes irrompidos apresentaram-se maiores no gênero feminino e no arco inferior, em todas as idades, não se observando diferenças significantes entre os lados direito e esquerdo. $\mathrm{Na}$ terceira parte deste estudo, considerou-se as medidas antropométricas de peso 
e estatura e a erupção de primeiros molares, incisivos centrais e laterais permanentes superiores e inferiores, com o objetivo de verificar as possíveis relações entre crescimento e desenvolvimento físicos e a erupção dentária. Os autores observaram uma relação positiva entre peso-erupção e estaturaerupção, sendo maior a correlação entre estatura-erupção.

Sabendo que o número de dentes permanentes irrompidos tem sido considerado como um excelente indicador do desenvolvimento biológico, principalmente quando associado a outros avaliadores somáticos, YARED125, em 1994, estudou a relação entre os parâmetros morfológicos de peso e altura e a erupção dos dentes permanentes, em função do nível sócio-econômico, da faixa etária e do gênero. A amostra consistiu de 2262 escolares, caucasianos de ambos os gêneros, da cidade de Araraquara, na faixa etária de 72 meses a 155 meses, divididos em dois grupos de níveis sócio-econômicos distintos. Os jovens foram examinados quanto ao número de dentes permanentes presentes na cavidade bucal, além de terem sido obtidas suas medidas de peso e altura. As análises estatísticas de correlação e regressão entre os indicadores somáticos de peso e altura e número de dentes permanentes presentes apresentaram resultados positivos e significantes com a fase 3 da erupção clínica (erupção completa e coroa clínica em contato com o dente antagonista), sendo mais expressiva com a idade cronológica. Entretanto, a correlação dos valores de peso e número de dentes permanentes presentes na cavidade bucal não foi significante para os escolares de nível sócio-econômico médio.

\subsubsection{Seqüência e cronologia de erupção dos dentes permanentes}

CATTELL17, em 1928, avaliou 7689 pacientes com o objetivo de estimar a idade dentária ou a idade biológica de acordo com a cronologia de erupção, tendo como base o irrompimento dos dentes permanentes na cavidade bucal. Não se encontrou diferença estatisticamente significante entre a época de erupção dos dentes permanentes do lado esquerdo e direito, com exceção do primeiro pré-molar superior direito que irrompeu, em média, 2 meses mais cedo do que seu correspondente do lado esquerdo. O gênero feminino mostrou um maior número de dentes irrompidos ou uma maior maturidade eruptiva em 
todas as faixas etárias. Observoutse uma grande variação ao longo do desenvolvimento dentário. O desenvolvimento de alguns dentes cessa em dois meses, enquanto outros não atingem a sua maturidade eruptiva depois de dezoito meses. Parece haver uma tendência de alguns dentes se desenvolverem mais rapidamente do que outros, e mesmo se considerando dentes iguais, há uma grande variação entre indivíduos diferentes.

No mesmo ano, COHEN 18 avaliou 2848 jovens, com idades variando entre 5 e 15 anos, com o propósito de determinar a idade média e a variabilidade na erupção de todos os dentes permanentes, com exceção dos terceiros molares. Houve uma tendência dos dentes das jovens do gênero feminino irromperem, em média, 5 meses mais cedo do que os dos jovens do gênero masculino. Além disso, o autor observou que havia a presença, em média, de um dente permanente irrompido a mais no arco inferior do que no arco superior em qualquer faixa etária dos indivíduos da amostra.

Conscientes da grande variabilidade do número de dentes permanentes presentes na cavidade bucal em determinada faixa etária, KLEIN; CODY55, em 1939, realizaram um estudo, onde observaram que os indivíduos do gênero feminino apresentaram uma maior variabilidade do que os indivíduos do gênero masculino quanto ao número de dentes permanentes presentes na cavidade bucal e que o gênero feminino apresentava, em média, um maior número de dentes permanentes presentes na cavidade bucal na faixa etária entre 6 e 15 anos.

Em 1941, SCHOUR; MASSLER ${ }^{103}$ realizaram uma breve revisão da literatura em relação ao desenvolvimento da dentição humana e cronologia de erupção desde a fase pré-natal até a completa formação da dentadura permanente. Ressaltaram que a idade de erupção de qualquer dente permanente na cavidade bucal é extremamente variável e depende da interação de diversos fatores, tais como a raça, gênero, nutrição, condição sistêmica e condições locais. A seqüência de erupção mais comumente encontrada foi a seguinte: 6-1-2-4-5-7-3. Concluíram que os dentes permanentes geralmente irrompem na cavidade bucal mais cedo em jovens do 
gênero feminino e que os dentes inferiores normalmente antecedem os dentes superiores.

No mesmo ano, MASSLER; SCHOUR ${ }^{74}$ realizaram um estudo onde relataram que o gênero feminino apresentava uma maior velocidade de erupção dentária do que o gênero masculino e que os dentes dos indivíduos do gênero feminino irrompiam em uma idade mais precoce do que os do gênero masculino. Afirmaram ainda, que este aspecto estava diretamente relacionado com o crescimento e desenvolvimento físico mais precoce em indivíduos do gênero feminino no período da infância. Isto se torna mais evidente entre gêmeos, uma vez que a herança genética e a influência do meio ambiente são semelhantes, diferindo apenas no gênero.

Devido àgrande discordância entre as tabelas existentes até o momento e à falta de informação a respeito do grau de variação que pode ser esperado ao examinar um grupo de tamanho considerável de jovens dos gêneros feminino e masculino, HURME48, em 1949, realizou uma precisa revisão da literatura a respeito da cronologia de erupção dentária. Analisou artigos oriundos de diversos países, publicados durante os 100 anos predecessores. Os dados analisados revelaram que não há diferenças significantes entre os gêneros no grau de variação da erupção dentária. $O$ fato das jovens do gênero feminino irromperem seus dentes em média cerca de 5 meses mais cedo que os do gênero masculino não altera esta situação. Os estatísticos interpretam esse fato dizendo que o desvio padrão para uma classe de dentes constitui no mesmo para ambos os gêneros. O grau de variação na emergência dentária pode ser determinado com um alto grau de confiabilidade para cada classe dos dentes permanentes.

Em 1951, STONES et al. ${ }^{113}$ examinaram 320 crianças, 180 do gênero masculino e 140 do feminino, por um período de 3 anos, a fim de obter informações a respeito da cronologia de erupção dos dentes permanentes e esfoliação dos dentes decíduos. Os autores ressaltaram que a cronologia de erupção do dente permanente depende em grande parte da época de esfoliação do seu dente decíduo predecessor. Ao se comparar os hemi-arcos 
direito e esquerdo, houve uma forte equivalência na cronologia de erupção dos dentes correspondentes, apesar de ter-se observado uma leve, porém, consistente tendência dos dentes permanentes do lado direito irromperem um pouco mais tarde que seus correspondentes do lado esquerdo. Os jovens do gênero masculino esfoliam seus dentes decíduos e irrompem seus dentes permanentes discretamente mais tarde do que os do gênero feminino. $O$ dimorfismo de gênero torna-se particularmente marcante com os caninos, sendo esta diferença de aproximadamente 10 a 11 meses.

A fim de estudar a cronologia de esfoliação dos dentes decíduos e a seqüência de erupção dos dentes permanentes, os intervalos de tempo entre a perda dos dentes decíduos e a erupção dos seus sucessores, e os efeitos aparentes desses fatores na incidência de más oclusões, KRONFELD58, em 1953, examinou clínica e radiograficamente 400 jovens durante um período de 14 anos, além de avaliar os modelos de estudo dos mesmos. Observou que a esfoliação dos dentes decíduos e a erupção dos permanentes ocorreram mais cedo do que a época relatada em estudos prévios; observou também, que quanto maior o intervalo de tempo entre a esfoliação normal do dente decíduo e a erupção do seu sucessor, maior a probabilidade de ocorrer um mal posicionamento desse dente permanente. Além disso, constatou que a seqüência de erupção dos caninos permanentes e dos pré-molares exerce pouca ou nenhuma influência no desenvolvimento da má oclusão; que a perda prematura de um dente decíduo no período de um a um ano e meio da época normal de esfoliação do mesmo, normalmente resulta em uma aceleração da erupção do seu dente sucessor, e que a perda muito precoce de um dente decíduo resulta em um atraso na erupção do dente sucessor e provavelmente em um mal posicionamento do mesmo.

No mesmo ano, LO; MOYERS 63 examinaram 236 jovens, sendo 116 do gênero feminino e 120 do gênero masculino, com o propósito de determinar se a seqüência de erupção dos dentes permanentes afetava a oclusão final, de verificar qual a seqüência de erupção ocorre mais freqüentemente e que tipo de oclusão resultava das diferentes seqüências de erupção. Verificaram 18 seqüências de erupção diferentes no arco superior e 17 no arco inferior. Em 
relação ao gênero, não houve diferença estatisticamente significante na seqüência de erupção ao se considerar todos os dentes do arco. A ordem de erupção apresentourse simétrica bilateralmente, com exceção de casos que apresentavam patologias localizadas. Os resultados deste estudo permitiram as seguintes conclusões: a) a seqüência de erupção mais freqüente na maxila foi 6-1-2-4-5-3-7; b) a seqüência de erupção mais freqüente na mandíbula foi 61-2-3-4-5-7; c) a combinação das seqüências de erupção 6-1-2-4-5-3-7 na maxila e 6-1-2-3-4-5-7 na mandíbula ocasionou a maior prevalência de uma relação molar normal; d) a seqüência de erupção mais desfavorável na maxila foi aquela em que os segundos molares irromperam antes dos caninos ou prémolares e na mandíbula foi aquela em que os caninos irromperam depois dos pré-molares ou quando os segundos molares irromperam antes dos caninos ou pré-molares; e) nos casos com relação molar de Classe II houve uma forte tendência dos molares superiores irromperem antes que os seus correspondentes inferiores; f) jovens do gênero feminino apresentaram uma maior prevalência da seqüência de erupção mais comumente encontrada, resultando em uma relação molar normal; e, g) o estudo da seqüência de erupção por meio de radiografias, em casos em que não há perdas prematuras de dentes decíduos, apresentou um certo valor prognóstico.

Estudando o padrão de erupção dos dentes humanos, NANDA82, em 1960, baseou-se nos dados coletados longitudinalmente de jovens acompanhados durante todo o período de suas vidas. Analisourse esses dados separadamente para a mandíbula e maxila, e para os gêneros. Não houve diferença entre os gêneros, nem no número de dentes presentes em uma determinada faixa etária, nem entre as idades médias de erupção nos jovens examinados. Os dentes inferiores irromperam mais cedo do que seus correspondentes na maxila, com exceção dos incisivos laterais decíduos e os primeiros molares permanentes, onde o inverso foi verdadeiro. $O$ estudo das diferentes seqüências de erupção dentária, normalmente responsabilizadas ou por favorecer ou por prejudicar o estabelecimento de más oclusões, revelou não haver nenhuma tendência específica. 
Em 1962, STURDIVANT; KNOTT; MEREDITH114 realizaram um estudo que apresentava como objetivos determinar a correlação de erupção para os dentes homólogos de cada arco dentário e dentes correspondentes do lado direito dos dois arcos e examinar a possibilidade de predizer a época de erupção dos caninos e pré-molares, a partir da época de erupção dos incisivos e primeiros molares. Examinaram longitudinalmente os modelos de estudo de 57 jovens leucodermas do gênero masculino. A idade média de erupção para os incisivos e caninos no arco inferior foi mais precoce do que a encontrada para os dentes correspondentes no arco superior. A variabilidade na idade de erupção apresenta-se menor para os primeiros molares, intermediária para os incisivos laterais, e maior para os caninos e segundos pré-molares. Houve uma forte correlação entre a época de erupção dos dentes dos lados direito e esquerdo de um mesmo arco dentário. As seqüências de erupção dentária que ocorreram com uma maior freqüência foram: 6-1-2-4-3-5-7 e 6-1-2-4-5-3-7 para 0 arco superior, e para o arco inferior: 1-6-2-4-3-5-7 e 1-6-2-3-4-5-7. Pode-se predizer a época de erupção do canino inferior com uma razoável confiabilidade a partir da época de erupção do incisivo lateral inferior.

Nesse mesmo ano, CARR ${ }^{14}$ buscou determinar a época de erupção dos dentes permanentes de jovens de Canberra, Austrália, além de determinar a diferença, se presente, entre as idades médias e medianas de erupção. A maioria dos trabalhos apresenta resultados que se referem às idades médias, entretanto, algumas pesquisas determinam as idades medianas de erupção dentária. Determinourse as idades de erupção dos dentes permanentes por dois métodos de pesquisa, o método transversal e o longitudinal, observandose apenas pequenas diferenças entre os resultados obtidos por esses métodos. As idades médias de erupção apresentaram-se de um a dois meses maiores que as idades medianas. Os dentes das jovens do gênero feminino irromperam em média cinco meses mais cedo do que os dos jovens do gênero masculino.

Ao examinar 1356 jovens escolares, leucodermas, de ambos os gêneros, brasileiros, da cidade de Araçatuba, distribuídos entre as idades de 5 a 13 anos, sendo 745 pertencentes a área urbana, e 611 a área rural, 
TOLEDO117, em 1963, objetivou avaliar a seqüência e a cronologia de erupção dos dentes permanentes, avaliar os prováveis efeitos da urbanização como um fator de variação da época de erupção e verificar a seqüência média de erupção dos dentes permanentes da maxila e da mandíbula. Observou que os dentes permanentes irromperam mais cedo nas jovens do gênero feminino que nos do gênero masculino. Além disso, as variações apresentadas entre a cronologia eruptiva das áreas urbana e rural não indicaram a precocidade ou 0 atraso de uma área em relação a outra.

No ano seguinte, ABRAMOWICZ1 visou estudar a erupção dos dentes permanentes em jovens judeus do grupo étnico Ashkenazim, pois nele, devido a questões religiosas, os endocruzamentos se verificam há várias gerações. autor considerou como ponto fundamental do trabalho, a criteriosa seleção da amostra, que foi constituída por 1538 alunos de escolas particulares da cidade de São Paulo, brasileiros, judeus do grupo étnico Ashkenazim, de níveis sócioeconômicos elevados, compreendidos no grupo etário de 5 a 13 anos completos. $O$ autor concluiu que não há diferenças maiores que um ano entre os gêneros no atributo considerado, salvo algumas exceções; somente os incisivos e o primeiro molar completaram sua erupção até os 13 anos de idade; considerando-se separadamente o gênero feminino, todos os dentes completaram sua erupção até os 13 anos de idade, com exceção do segundo e do terceiro molar; não há diferenças maiores de um ano entre a cronologia de erupção dos dentes superiores e os inferiores; não há diferenças entre a cronologia de erupção dos dentes do lado direito e esquerdo de ambos os arcos, com algumas exceções; apesar da influência de determinados fatores na cronologia de erupção dentária, esta apresenta-se relativamente constante, advindo daí seu interesse prático nas perícias odonto-legais de determinação da idade.

Buscando analisar as diferenças de comportamento relativas à seqüência e cronologia de erupção dos dentes permanentes entre brasileiros brancos e judeus Ashkenazim da cidade de São Paulo, ARBENZ; ABRAMOWICZ2 ${ }^{2}$, em 1964, analisaram duas amostras e estabeleceram a seqüência de erupção para ambas. A primeira era constituída de 2030 alunos 
de escolas públicas da cidade de São Paulo, leucodermas e do grupo etário de 7 a 13 anos. A segunda era composta por 1538 jovens judeus do grupo étnico Ashkenazim, de níveis sócio-econômicos elevados, de escolas particulares da cidade de São Paulo, compreendidos no grupo etário de 5 a 13 anos completos. Os autores concluíram que a seqüência e a cronologia de erupção se diferiram nas duas amostras, sendo que na maioria dos casos, a erupção dentária ocorreu mais cedo no grupo dos jovens judeus, e que o número de dentes permanentes irrompidos é um caráter melhor para as estimativas de idade do que a seqüência ou cronologia de erupção.

No ano seguinte, MILLER; HOBSON; GASKELL78 avaliaram a cronologia de esfoliação dos dentes decíduos e erupção dos dentes permanentes. Observou-se que o padrão de esfoliação dos dentes decíduos apresentou-se semelhante ao encontrado por STONES et al. ${ }^{113}$, em 1951, tanto em relação à seqüência quanto às idades médias de esfoliação dos dentes decíduos. Os dentes esfoliaram mais cedo nas jovens do gênero feminino do que nos jovens do gênero masculino. Em relação à erupção dentária, as jovens do gênero feminino apresentaram uma idade média de erupção para cada dente permanente menor do que os jovens do gênero masculino; a variação do tempo durante o qual os dentes irromperam apresentou-se semelhante para ambos os gêneros.

Em 1965, GRABER38 considerou que existe uma variação considerável na seqüência de erupção dos caninos e pré-molares. Citou ainda que normalmente o canino inferior irrompe antes dos primeiros e segundos prémolares. Na maxila, o primeiro pré-molar irrompe antes do canino. O segundo pré-molar e o canino irrompem aproximadamente ao mesmo tempo. Se houver espaço suficiente, não se deve dispensar muita importância à variação desta ordem. A erupção do segundo molar ocorre normalmente pouco tempo depois da erupção do segundo pré-molar. Como estes dentes variam consideravelmente em suas erupções, mais do que quaisquer outros dentes, o segundo molar pode irromper antes do segundo pré-molar. Os segundos molares irrompem, tanto na maxila quanto na mandíbula, aproximadamente ao mesmo tempo. Se o segundo molar permanente irromper antes do segundo 
pré-molar, o primeiro molar pode se inclinar para a mesial, principalmente se o paciente apresentar perda prematura do segundo molar decíduo. Se os molares se encontram inclinados para mesial, a erupção do segundo pré-molar poderá se atrasar. Este dente irromperá por lingual ou não irromperá. $O$ autor observou que, em uma grande quantidade de casos de má oclusão de Classe II, divisão 1 , o segundo molar superior tende a irromper antes do seu antagonista inferior.

Com o propósito de avaliar longitudinalmente a idade e a seqüência de emergência gengival dos dentes permanentes, KNOTT; MEREDITH ${ }^{56}$, em 1966, analisaram os modelos de estudo de 107 jovens leucodermas, de nacionalidade americana, com o nível sócio-econômico superior à média. Os autores concluíram que: incisivos e caninos atravessaram a mucosa alveolar em idades mais precoces na mandíbula do que na maxila; os caninos inferiores apresentaram o maior dimorfismo de gênero em relação àidade de emergência gengival; as variações para a época de erupção foram menores para os incisivos e primeiros molares do que para caninos e pré-molares; houve uma associação moderadamente forte entre a época de erupção para os dentes permanentes homólogos nos dois lados de um mesmo arco dentário e para os dentes correspondentes do lado direito de ambos os arcos dentários; as seqüências de erupção que ocorreram para cada gênero com uma maior freqüência foram: 6-1-2-4-3-5-7 e 6-1-2-4-5-3-7 para o arco superior e 1-6-2-34-5-7 para o arco inferior; pôde-se predizer satisfatoriamente a idade de erupção do canino inferior, a partir da idade de erupção do incisivo lateral inferior, com erros inferiores a 7 meses para 2 jovens em 3 e inferiores a 14 meses para 19 jovens em 20.

Considerando-se a grande variabilidade na erupção dos dentes permanentes e que os fatores ambientais e genéticos, destes em particular os étnicos, exercem uma significativa influência neste processo, além dos cuidados que devemos ter na aceitação de parâmetros de uma região para a outra, SOUZA-FREITAS; ÁLVARES; LOPES108, em 1970, realizaram um estudo com 3688 jovens brasileiros da cidade de Marília, leucodermas de terceira geração, (descendentes de avós portugueses, italianos e espanhóis) 
de ambos os gêneros, com idades cronológicas compreendidas entre 51 a 168 meses. Da análise dos dados obtidos, os autores concluíram que houve uma diferença estatisticamente significante na erupção dos dentes permanentes, com precocidade para o gênero feminino e que exceto para os primeiros e segundos pré-molares no gênero masculino e primeiro pré-molar no feminino, os dentes inferiores irromperam mais cedo que seus homólogos do arco superior.

De acordo com GARN; BURDß4, em 1971, a seqüência de erupção dos dentes permanentes apresenta uma mudança progressiva desde os primatas, que apresentavam a provável ordem: M1-M2-M3-11-I2-PM1-PM2-C, até o homem atual. Há uma grande variabilidade na seqüência de erupção dos dentes permanentes. Por exemplo, os caninos permanentes podem irromper precocemente na seqüência, como uma característica do homem futuro ou mais tarde na ordem de erupção, como uma característica do atavismo. A seqüência de erupção dos dentes permanentes varia entre a maxila e a mandíbula e entre os gêneros. Os dentes inferiores apresentam uma tendência a preceder seus correspondentes superiores na região anterior, contudo, tendem a seguí-los na região posterior. Pode-se observar radiograficamente uma seqüência de formação dentária com o segundo molar se desenvolvendo precocemente em relação ao segundo pré-molar e o mesmo jovem apresentar uma seqüência de erupção dentária com o segundo pré-molar irrompendo antes do segundo molar. Há uma grande correlação no desenvolvimento dentário entre os dentes correspondentes de cada lado de um mesmo arco dentário. Os dentes oponentes, apesar de se encontrarem em arcos dentários diferentes, apresentam uma correlação discretamente menor que a citada anteriormente. Os dentes permanentes de jovens do gênero feminino se desenvolvem à frente dos dentes permanentes dos jovens do gênero masculino.

MARQUES; GUEDES-PINTO; ABRAMOWICZ72, no ano de 1978, examinaram 1741 jovens brasileiros, nascidos na cidade de São Paulo, com idades variando entre 4 e 14 anos. Os autores observaram que os dentes permanentes das jovens do gênero feminino irromperam antes daqueles dos 
jovens do gênero masculino. Além disso, os dentes da mandíbula irromperam antes que seus correspondentes maxilares, com exceção dos pré-molares, onde ocorreu o inverso. Os resultados desse estudo ressaltaram a importância dos trabalhos realizados para nossa população, uma vez que foram observadas diferenças consideráveis dos dados obtidos com os apresentados por autores estrangeiros.

A fim de avaliarem a cronologia e seqüência de erupção dos dentes permanentes, SAVARA; STEEN102, em 1978, examinaram clínica e radiograficamente 124 jovens do gênero masculino e 163 do feminino de Oregon, filhos de pais de classe sócio-econômica média e média-alta, com idades entre 4 e 15 anos, além de analisarem os modelos de estudo dos mesmos, por meio de um estudo longitudinal. As diferenças nas idades de erupção entre os dentes homólogos em cada arco apresentaram-se pequenas ou inexistentes. Em relação ao gênero, as jovens do gênero feminino apresentaram uma maior variabilidade e uma maior precocidade na idade de erupção. A seqüência de erupção mais freqüente para a maxila das jovens do gênero feminino foi 6-1-2-4-3-5-7 e para a mandíbula foi 1-6-2-3-4-5-7. Para os jovens do gênero masculino, a seqüência de erupção mais freqüente foi 6-1-24-5-3-7.

Objetivando estudar a seqüência de erupção dos dentes permanentes em 448 jovens do gênero masculino, na faixa etária de 7 a 10 anos e 11 meses, PARREIRA et al. ${ }^{91}$, em 1982, examinaram radiografias periapicais de todos os dentes decíduos e permanentes desses jovens, sendo observada a posição de cada dente permanente e sua relação com o plano oclusal (na radiografia). Os autores concluíram que a seqüência provável de erupção para os dentes do arco superior era 6-1-2-4-5-3 em $85 \%$ dos casos, enquanto que para o arco inferior era 6-1-2-3-4-5 em 84\%; as seqüências favoráveis de erupção observadas nesse estudo estavam de acordo com a maioria dos autores, variando apenas nos percentuais apresentados. Estes resultados sugerem que a ordem de aparecimento dos dentes na cavidade bucal mantémse relativamente constante e que as discrepâncias geralmente observadas, poderiam estar relacionadas a fatores locais e sistêmicos que afetam 0 
desenvolvimento de cada dente individualmente. Comparando os resultados da erupção dos dentes permanentes em jovens do gênero masculino com os resultados de uma pesquisa anterior, realizada por VIANNA et al. ${ }^{120} \mathrm{em}$ 1979, que estudaram de maneira semelhante a seqüência de erupção em jovens do gênero feminino, verificou-se haver uma proporcionalidade na seqüência de erupção em ambos os gêneros.

Dois anos mais tarde, HÖFFDING et al. 46 realizaram um estudo com a finalidade de obter um padrão da época de erupção na população japonesa, por meio do exame de 1819 jovens com idades entre 6 e 15 anos. Os resultados revelaram seqüências específicas de erupção em ambos os arcos dentários e a existência de dimorfismo de gênero na época do irrompimento dentário na cavidade bucal, havendo uma precocidade para o gênero feminino. Além disso, os autores compararam os resultados encontrados com aqueles obtidos de uma amostra do ano de 1934, e observaram, em geral, uma tendência de erupção mais precoce dos dentes na população japonesa contemporânea.

Visando a avaliação das diferenças entre a época de erupção dos dentes permanentes de jovens de duas populações indígenas distintas, de uma determinada região canadense e discutir suas significâncias, TITLEY'16, em 1984, examinou 1191 jovens escolares com idades entre 5,5 e 17,4 anos. Os resultados mostraram que, em geral, as jovens do gênero feminino apresentaram um período de erupção dentária estatisticamente significante mais precoce do que os do gênero masculino, e a seqüência de erupção dentária em ambos os gêneros apresentourse semelhante (na maxila: 6-1-2-45-3-7; na mandíbula: 6-1-2-3-4-5-7). De acordo com o autor, as evidências sugerem que as populações canadenses exibem uma diversidade no período de emergência dos dentes permanentes, que pode ser atribuída a diferenças genéticas, especialmente quando se estuda comunidades menores, onde pode se encontrar uma população bem mais homogênea, a altos índices de cárie dentária na dentadura decídua, e às condições climáticas e sócio-econômicas. 
No ano seguinte, HÄGG; TARANGER ${ }^{42}$ realizaram um estudo longitudinal desde o nascimento até os 18 anos de idade em 212 indivíduos suecos, enfocando especialmente a época da emergência dos dentes na cavidade bucal. Os autores observaram que a diferença média entre a idade dentária estimada e a idade cronológica foi de aproximadamente um mês em ambos os gêneros e que no gênero feminino, a emergência dos dentes na cavidade bucal ocorreu mais precocemente, com exceção do terceiro molar, que irrompeu mais cedo em indivíduos do gênero masculino.

Visando fornecer novas informações a respeito da freqüência das diferentes seqüências de erupção dos dentes permanentes, SMITH; GARN105, em 1987, examinaram transversalmente 6000 jovens americanos leucodermas e melanodermas. A mandíbula apresentou uma maior variação nas seqüências de erupção dentária do que a maxila. O dimorfismo de gênero ocorreu para as seqüências do canino (apenas em leucodermas) e para as seqüências 6-1/1-6 (em ambas as populações). O gênero masculino apresentou uma maior freqüência das seqüências em que o canino irrompe mais tardiamente, e maior freqüência da seqüência 1-6 do que o gênero feminino. Os leucodermas apresentaram uma maior ocorrência das seqüências em que os molares irrompem mais tardiamente (por exemplo, 1-6 e 5-7) quando comparados aos melanodermas. O pequeno intervalo de tempo entre a época de erupção dos dentes dos dois principais grupos eruptivos (6-1-2, e 3-4-5-7) pode constituir o principal fator para se explicar a magnitude da variação da seqüência de erupção dos dentes humanos. De acordo com os autores, os genes relacionados æ̀s seqüências eruptivas onde há a tendência dos molares irromperem mais tardiamente (1-6 e 5-7) podem também predispor a uma mineralização tardia, a um tamanho menor, a uma morfologia mais simples, ou à agenesia de dentes nas séries dos molares. As seqüências de erupção dentária mais freqüentes foram: 6-1-2-(4-3-5)-7 na maxila, e (6-1)-2-(3-4)-(5-7) na mandíbula.

Em 1991, BURDI; MOYERS12 afirmaram que a época da erupção dentária correlaciona-se dentro de uma dentição, ou seja, os jovens que irrompem qualquer dente precoce ou tardiamente tendem a irromper os demais 
dentes de maneira semelhante. Afirmaram ainda que, exceto para os terceiros molares, jovens do gênero feminino irrompem seus dentes permanentes, em média, 5 meses mais precocemente do que os do gênero masculino. A variabilidade da época de erupção normal é pequena quando comparada com a variabilidade normal do desenvolvimento esquelético. Ressaltaram que a aparente seqüência do desenvolvimento da mineralização não é um indício seguro para a seqüência do irrompimento na boca, uma vez que os fatores que regulam e afetam a velocidade de erupção variam entre os dentes. Há uma grande variabilidade na seqüência do aparecimento dos dentes na cavidade bucal. Na maxila, as seqüências 6-1-2-4-3-5-7 e 6-1-2-4-5-3-7 são observadas em quase metade dos casos, ao passo que na mandíbula as seqüências (6-1)2-3-4-5-7 e (6-1)-2-4-3-5-7 incluem mais de $40 \%$ de todos os jovens. $O$ irrompimento do segundo molar antes dos caninos ou dos pré-molares apresenta grande tendência a encurtar o perímetro do arco e pode criar dificuldades de espaço.

No mesmo ano, GALVÃO32 desenvolveu uma pesquisa com o propósito de avaliar clinicamente a cronologia e a seqüência de erupção dos caninos permanentes e pré-molares em 401 escolares das zonas urbana e rural de Araçatuba - SP, na faixa etária de 11 a 15 anos, eventos estes que ocorrem à época do surto de crescimento pubescente. Sabe-se que este período inicia-se mais precocemente no gênero feminino, com aproximadamente 2 anos de diferença. $O$ autor concluiu que a seqüência de erupção mais freqüente dos caninos e pré-molares foi: no arco inferior 3-4-5; para o arco superior 4-5-3. Muitos ortodontistas consideram estas seqüências ideais 56,63 por proporcionarem melhores condições no estabelecimento de uma oclusão clinicamente aceitável. Na faixa etária de 14 a 15 anos, todos os caninos e prémolares já haviam irrompido. De um modo geral, os dentes dos escolares do gênero feminino irromperam precocemente que os dos escolares do gênero masculino nas regiões pesquisadas. Para o arco dentário superior não houve alteração na seqüência eruptiva em relação ao gênero. No arco inferior, para o gênero masculino, os primeiros pré-molares irromperam antes dos caninos, enquanto que, para o gênero feminino, a seqüência foi aquela considerada ideal. 
De acordo com GUEDES-PINTO39 (1997), as crianças que nascem e vivem em países cuja temperatura média anual apresenta-se baixa, parece haver um discreto retardo na época de erupção dos dentes permanentes, quando comparadas com aquelas nascidas em países tropicais e em um mesmo país, as crianças nascidas e criadas em cidades litorâneas parecem ter erupção dentária mais precoce.

Objetivando avaliar as possíveis diferenças na época e nos padrões da emergência dos dentes permanentes em diferentes regiões da Finlândia, ESKELI et al.29, em 1999, examinaram dois grupos de jovens finlandeses de comunidades rurais, 1008 da parte leste do país e 569 da parte oeste, com idades entre 5 e 16 anos, a fim de determinar a época de emergência dos dentes permanentes e alguma variação regional existente. Os incisivos e primeiros molares permanentes irromperam mais cedo e os pré-molares irromperam mais tarde do que as médias previamente relatadas para as populações escandinavas. Os primeiros achados refletiram a tendência secular; os últimos provavelmente relacionam-se à melhora evidente na saúde bucal das crianças finlandesas. Não se verificou nenhuma variação regional em relação à erupção dentária. As crianças do gênero feminino irromperam seus dentes permanentes significantemente mais cedo que as do gênero masculino. Os dentes permanentes inferiores nas regiões de incisivos e caninos irromperam mais cedo que seus correspondentes superiores. Nos segmentos posteriores houve pouca diferença na erupção dos dentes superiores e inferiores correspondentes.

Com o propósito de estabelecer a seqüência de erupção para mamíferos primatas, HARVATH4, em 2000, avaliou 204 espécies e encontrou uma relação entre o desenvolvimento dentário, a dieta e o ambiente em que viviam. $\mathrm{O}$ autor afirmou que a seqüência de erupção dentária consiste em um reflexo dos padrões de vida de grande parte das espécies que pertencem à classe dos mamíferos. 


\subsubsection{Fatores gerais e locais que influenciam a erupção dos dentes permanentes}

Existem inúmeros fatores capazes de alterar a seqüência e/ou a cronologia de erupção dos dentes permanentes. Esses fatores podem ser de ordem geral ou local e serão enfocados separadamente neste trabalho por razões didáticas.

\subsection{Fatores de ordem geral}

Estudando a influência da raça sobre a idade média de erupção dentária, STEGGERDA; HILL112, em 1942, realizaram uma comparação entre os gêneros, mandíbula e maxila em relação à seqüência de erupção dentária. Estudou-se longitudinalmente três raças: branca, negra e indígena, sendo que na raça indígena estudourse duas etnias, os Navajos e os Mayas. A época de erupção dos hemi-arcos direito e esquerdo apresentourse semelhante. Os dentes dos indivíduos do gênero feminino irromperam antes em relação aos do gênero masculino nos quatro grupos estudados. Em relação à raça, pode-se dizer que os dentes irromperam mais precocemente nos grupos estudados na seguinte ordem: Navajo, Negra, Maya e Branca. A época de erupção para todos os dentes na raça negra foi mais precoce do que na raça branca, exceto para os segundos pré-molares superiores. Em relação àseqüência de erupção, os dentes inferiores normalmente irromperam antes dos seus correspondentes superiores, mas esta diferença apresentou grandes variações. Assim, a seqüência de erupção dentária foi praticamente a mesma em todas as raças estudadas, diferindo entre a maxila e a mandíbula e entre os gêneros. As seqüências de erupção encontradas foram: maxila/masculino: 6-1-2-4-5-3-7; mandíbula/masculino: 6-1-2-4-3-5-7; maxila/feminino: 6-1-2-4-3-5-7; mandíbula/feminino: 6-1-2-3-4-5-7.

Com o propósito de avaliar a influência dos fatores hereditários e ambientais no desenvolvimento da dentição, NISWANDER ${ }^{86}$, em 1963, analisou os efeitos da procriação consangüínea na erupção dos dentes permanentes e comparou as diferenças dessa erupção dentária entre os filhos 
de casais aparentados e não aparentados. Os dados dessa pesquisa foram oriundos de um estudo de consangüinidade realizado no Japão, entre 1958 e 1960. Foram examinados aproximadamente 3.500 filhos de casais de primos e um número equivalente de jovens como controle. Não se observou nenhum efeito da procriação consangüínea na erupção dentária, assim, o número de dentes irrompidos em uma determinada faixa etária não depende de fatores genéticos, enquanto que uma positiva correlação foi encontrada entre o nível sócio-econômico e a erupção dentária, evidenciando um envolvimento dos fatores ambientais. Observou-se uma tendência de irmãos apresentarem uma maior semelhança nos padrões da erupção dentária do que jovens não irmãos em idades similares, mas não se notou nenhum efeito da consangüinidade na variação entre irmãos.

Em 1965, GRABER38 considerou que distúrbios endócrinos podem alterar a erupção dos dentes permanentes, como por exemplo, os distúrbios nas tireóides, que são comuns e seus efeitos podem ser observados no desenvolvimento da oclusão. As enfermidades febris podem desordenar a cronologia do desenvolvimento dentário, assim como provocar distúrbios locais ambientais.

Objetivando verificar a possível influência da fluoretação na cronologia de erupção dos dentes permanentes, SOUZA-FREITAS et al. ${ }^{110}$, em 1971, examinaram dois grupos de jovens, um constituído de jovens residentes na cidade de Marília, onde a água de abastecimento público era fluoretada e o outro na cidade de Ribeirão Preto, em uma região onde a água de abastecimento público não continha fluoretos. Da comparação entre os grupos, observourse que houve um atraso na erupção dentária na população da cidade de Marília (água fluoretada) em relação à de Ribeirão Preto (água não fluoretada).

No mesmo ano, KRUMHOLT; ROED-PETERSEN; PINDBORG59 ressaltaram a influência da raça na cronologia de erupção dos dentes permanentes. Estabeleceurse a época de erupção dos dentes permanentes para 622 jovens melanodermas de Uganda. Os dentes permanentes dos 
jovens examinados apresentaram uma aceleração da erupção em comparação com populações caucasianas. Nem a fluoretação da água de abastecimento, nem a prevalência de cáries e nem as extrações de dentes decíduos nas regiões geográficas estudadas puderam ser responsabilizadas por tal aceleração. Os negros irromperam seus dentes em média 1 a 1,5 ano àfrente dos caucasianos.

Pelo exame de 182 jovens dominicanos com idades variando entre 2,9 e 14 anos, de distintos níveis sócio-econômicos e com impedimentos mentais, MOLINA; VIÑAS; GARCÍA-GODOY79, em 1982, observaram que esses jovens apresentaram um retardo na época de erupção dos dentes permanentes em relação a estudos prévios, realizados em jovens sem comprometimentos mentais ${ }^{17}$. Aparentemente, o grau de comprometimento mental das crianças pareceu influenciar a idade de erupção, já que nessa pesquisa, as crianças portadoras de Síndrome de Down iniciaram o processo eruptivo mais tarde que as crianças com paralisia cerebral. Os autores recomendaram a realização de mais estudos a esse respeito, enfocando os distintos graus de comprometimento mental.

Para BURDI; MOYERS12 (1991), tanto a seqüência quanto a época de erupção dentária são, em grande parte, determinadas pelos genes. Além disso, há seqüências e épocas de erupção que são típicas para certos grupos raciais. As influências nutricionais sobre a mineralização e a erupção dos dentes são pouco significantes, sendo observadas somente nos extremos da variação nutricional. Tanto a mineralização, quanto a erupção respondem menos aos distúrbios endócrinos do que o desenvolvimento esquelético.

Em 1994, VIRTANEN; BLOIGU; LARMAS121 desenvolveram uma pesquisa retrospectiva com o propósito de investigar se há diferenças na maturação dentária entre jovens de diferentes partes da Finlândia e entre comunidades com e sem flúor endêmico. A diferença entre os gêneros também foi avaliada. Obtiveram os dados de 911 jovens, com idades variando entre $3 \mathrm{e}$ 21 anos. As diferenças na época de erupção entre dentes homólogos de um mesmo arco dentário foram pequenas ou inexistentes, mas os dentes inferiores 
irromperam mais cedo do que seus correspondentes superiores. Todos os dentes irromperam mais cedo no gênero feminino, com diferenças variando entre 0,1 a 1,0 ano, dependendo do dente. A erupção dos dentes da segunda fase da dentadura mista (caninos, pré-molares e segundos molares) foi estatisticamente significante mais tarde para os jovens residentes na região com flúor endêmico na água de abastecimento público, sendo esta diferença maior para o gênero masculino do que para o feminino.

VALLADARES-NETO; SILVA; KAADI119, em 1995, relataram que geralmente os fatores gerais relacionados ao retardo ou ausência da erupção dentária afetam vários dentes e geralmente apresentam outros sinais e sintomas que auxiliam a formular o diagnóstico. Dentre esses fatores gerais citados pelos autores, destacam-se a hereditariedade, distúrbios endócrinos (hipopituitarismo, hipoparatireoidismo, hipotireoidismo), deficiências nutricionais (hipovitaminoses A e D), a disostose cleidocraniana, a síndrome de Down, a displasia ectodérmica, a sífilis congênita, a amelogênese imperfeita, as fissuras lábio-palatinas, o uso sistêmico de flúor, a fibromatose gengival, a consistência alimentar, as doenças febris e ainda, fatores idiopáticos.

No ano seguinte, PACKOTA; PHAROAH; PETRIKOWSK $\beta 0$ descreveram os principais achados radiográficos em doze indivíduos portadores de displasia odontomaxilar. As características mais comuns foram a presença de um trabeculado ósseo mais delgado e esclerótico, a ausência dos pré-molares, seio maxilar com dimensões reduzidas e uma erupção tardia dos dentes permanentes posteriores. As características observadas com menor freqüência foram o alargamento das coroas, raízes e polpa dos molares decíduos e a reabsorção irregular das raízes dos molares decíduos, o que pode interferir no processo de erupção dos dentes sucessores permanentes.

Em 1997, RASMUSSEN; KOTSAKP5 consideraram o termo retardo eruptivo para designar os casos onde a erupção torna-se dificultada, causando uma interrupção na coordenação da formação e erupção dentárias. O fenômeno pode ser local ou geral, e diversos fatores etiológicos podem estar envolvidos, como a falta de espaço, anquilose, cisto, dentes supranumerários, 
deficiências hormonais e de vitaminas e diversas síndromes (síndrome de Down) e distúrbios do desenvolvimento (hipopituitarismo). Os autores descreveram alguns casos de um tipo especial de retardo eruptivo hereditário. O material desse estudo consistiu de 14 casos de 10 famílias residentes da região de Bergen, Noruega. Desses casos, oito pertenciam a 4 grupos de irmãos. Dois desses grupos eram ligados por avós em comum. Os demais pacientes eram os únicos afetados entre os irmãos, mas na maioria dos casos um dos pais era afetado. Assim, em 11 dos 14 pacientes, um dos pais era afetado, em 6 casos também um dos avós. A idade dos pacientes no primeiro exame variou entre 5 e 14 anos. Os principais achados clínicos e radiográficos no retardo eruptivo hereditário foram: 1) todos os dentes da dentadura permanente foram afetados, ̀̀ vezes também alguns dos segundos molares decíduos; 2) a cronologia da formação dentária apresentou-se dentro de limites normais. Os dentes terminaram seu desenvolvimento posicionados profundamente nos ossos basais, freqüentemente em posições aberrantes e com raízes em forma de gancho; 3) a extração dos dentes decíduos, a fim de estimular a erupção dos sucessores não obteve sucesso na maioria dos casos; 4) muito freqüentemente, os dentes com retardo irromperam sem intervenção. As posições aberrantes e raízes em forma de gancho pareceram não impedir a erupção; 5) secundariamente à falha primária de erupção, outros distúrbios podem aparecer, causados por migração dentária, falta de espaço, fibrose gengival, reabsorção radicular, reabsorção patológica. Estes distúrbios podem impedir a erupção especialmente entre os grupos de erupção dentária tardia; 6) os dentes reagiram às forças ortodônticas. Portanto, a anquilose não parece ser o mecanismo responsável pelo retardo eruptivo.

FRANKLIN; ROBERTS31, em 1998, relataram um caso clínico de uma criança do gênero masculino, de 6 anos de idade, portador de hipertricose lanuginosa, onde se observou um atraso na erupção dentária. Na hipertricose lanuginosa congênita, o corpo é coberto por um denso pêlo ao nascimento, que persiste e é constantemente renovado ao longo da vida. A hipertricose lanuginosa congênita é muito rara. As únicas partes do corpo que não são cobertas por pêlos são as palmas das mãos e as solas dos pés. Anomalias dentárias como dentes neonatais, hipodontia, a presença de dentes 
supranumerários, e defeitos no esmalte podem estar relacionados com a hipertricose lanuginosa. O presente caso ilustra um atraso na erupção dos dentes decíduos e permanentes, resultando em uma morfologia radicular incomum dos molares decíduos, e também hipoplasia de esmalte. Não havia história familiar de hipertricose lanuginosa congênita por parte dos pais e a criança do presente relato parecia ter um desenvolvimento físico e mental normais. Aos 2 anos de idade nenhum dente havia irrompido. Aos 3 anos e meio, os incisivos centrais inferiores decíduos irromperam. As radiografias confirmaram a presença de todos os dentes decíduos, dos incisivos, caninos e primeiros molares permanentes. Até o momento, não havia evidências de desenvolvimento dos pré-molares e segundos molares inferiores. Normalmente, a mineralização das coroas dos pré-molares se completa entre as idades de 5 e 7 anos. Não havia nenhuma evidência radiográfica do desenvolvimento de dentes supranumerários que pudesse estar impedindo a erupção de alguns dentes. O esmalte dos dentes irrompidos no presente caso apresentava-se hipoplásico. No momento, não havia nenhum plano de tratamento para o paciente, e adotou-se a estratégia de um acompanhamento até o momento em que o paciente se tornar preocupado com sua dentição.

No mesmo ano, KALK; BATENBURG; VISSINK53 abordaram a displasia dentinária do tipo I, que consiste em um defeito genético da formação da dentina, herdado como uma característica autossômica dominante. Apesar de ser descrita classicamente como um defeito isolado, a displasia dentinária pode estar associada a diversas desordens. Clinicamente, os dentes apresentam um caráter morfológico normal. O primeiro sinal da displasia dentinária do tipo I pode ser a esfoliação prematura de dentes, ou espontaneamente ou secundariamente por trauma, mas também tem se relatado um atraso nos padrões de erupção dentária. Tanto na dentadura decídua, como na permanente, a desordem é caracterizada radiograficamente por obliteração da câmara pulpar parcial ou total, formação radicular defeituosa e uma tendência a radiolucidez periapical sem uma causa aparente. Neste relato foram descritos 5 casos desta rara desordem que se desenvolveu dentro de uma família, ocorrendo um atraso da erupção dentária e considerou-se uma visão atual sobre a manifestação, classificação e tratamento. 
ROSENBLUM97, em 1998, relatou um caso clínico de um paciente com 14 anos e 9 meses de idade, que apresentava um atraso no desenvolvimento dentário e que era portador da síndrome de Gorlin-Goltz. Esta síndrome apresenta como sinal principal a existência de múltiplos cistos na região ca maxila e da mandíbula, e até então, nenhum estudo havia enfatizado a seqüência e cronologia de erupção dos dentes permanentes em pacientes portadores desta patologia. $O$ autor considerou a hipótese do caso clínico apresentado ser apenas uma mera coincidência entre uma doença sistêmica e uma manifestação de desenvolvimento dentário atrasado. $O$ autor sugeriu que novos estudos sejam desenvolvidos em pacientes portadores desta síndrome, no intuito de confirmar a influência da mesma no desenvolvimento dentário.

No ano seguinte, McNAMARA et al. ${ }^{76}$ relataram um caso clínico de erupção dentária precoce de um primeiro pré-molar superior, em um paciente portador de fissura palatina e afirmaram que esta precocidade no processo de erupção dentária, tanto na dentição decídua como na permanente, pode ocorrer devido a manifestações de natureza sistêmica, como por exemplo, a hipofosfatasia, o hipertireoidismo, a leucemia linfóide aguda, a neutropenia, a histiocitose $X$, a síndrome de Papillon-Lefèvre e o querubismo. Os autores ressaltaram a importância de um controle adequado do processo da erupção dentária em pacientes com as referidas condições sistêmicas sob pena de comprometer a permanência de elementos dentários na cavidade bucal.

Discorrendo a respeito da displasia cleidocraniana, McNAMARA et al. 77 (1999) conceituaram-na como uma desordem congênita rara dos ossos, caracterizada por anomalias das clavículas, crânio e ossos basais, bem como por eventual atrofia dos ossos longos. As manifestações bucais constituem na falha da erupção dos dentes permanentes e na presença de múltiplos dentes supranumerários. O propósito desse trabalho foi revisar as características radiográficas desta condição e relatar a efetividade da radiografia panorâmica na identificação de características patognomônicas da displasia cleidocraniana. Para isto, os autores analisaram radiografias panorâmicas de 9 pacientes caucasianos, do gênero masculino, portadores de displasia cleidocraniana. Além das complicações dentárias estabelecidas (falha na erupção dos dentes 
permanentes e a presença de múltiplos dentes supranumerários), estavam presentes também anomalias morfológicas da maxila e da mandíbula, particularmente no ramo ascendente e no processo coronóide da mandíbula. Assim, os autores concluíram que a radiografia panorâmica constitui um valioso coadjuvante na confirmação do diagnóstico da displasia cleidocraniana.

Em 2000, O’CONNELL et al. 89 avaliaram 34 indivíduos portadores da síndrome de hiperimunoglobulinemia $E$ para verificar a incidência de anormalidade na erupção dentária. Determinourse a relação entre a idade cronológica, a idade dentária e a idade na época da erupção dentária. Os resultados mostraram que $75 \%$ dos pacientes com idade maior que 7 anos apresentaram problemas na erupção dos dentes permanentes, como por exemplo, a retenção prolongada de dentes decíduos e a necessidade de extrações de tais dentes, para permitir a erupção dos sucessores permanentes. A erupção dos primeiros e segundos molares permanentes ocorreu em época adequada. Em todos os casos, a diferença entre a idade cronológica e a idade dentária apresentourse menor que 12 meses; no entanto, ocorreu uma diferença estatisticamente significante entre a idade cronológica e a idade média de erupção dos dentes em $80 \%$ dos casos, quando se considerou valores padrões. As alterações no processo de erupção dentária ocorreram principalmente pelo atraso na esfoliação dos dentes decíduos, em vez de um atraso no desenvolvimento e formação dos dentes permanentes.

No mesmo ano, BEKISZ; DARIMONT; ROMPEN5 descreveram um caso clínico de hipertrofia gengival unilateral difusa associada com a neurofibromatose de von Recklinghausen, em uma criança do gênero feminino, de 8 anos de idade. A criança apresentava a seguinte situação: uma hipertrofia importante não inflamatória, difusa, unilateral, da gengiva interproximal, marginal e inserida em volta de todos os dentes do lado direito, tanto da maxila como da mandíbula, enquanto que os processos alveolares do lado esquerdo, tanto do arco superior como inferior, apresentavam-se estritamente normais. $O$ exame clínico revelou um atraso na erupção de alguns dentes permanentes do lado direito, tanto do arco superior como do inferior. Essa manifestação unilateral sugeria uma patologia vascular ou neurológica. Diversas manchas 
"café-au-lait" foram encontradas disseminadas pelo corpo. Realizourse a remoção cirúrgica de algumas partes desse espesso tampão de gengiva, que dificultava a erupção de alguns dentes permanentes e esses tecidos removidos foram analisados histologicamente. Devido à presença das manchas "café-aulait", foi dado um diagnóstico clínico da doença de von Recklinghausen, que foi confirmado posteriormente pelas biópsias gengivais analisadas histologicamente. A remoção cirúrgica seletiva dos neurofibromas gengivais permitiu a erupção dos dentes permanentes.

Para avaliar a cronologia, a seqüência de erupção e a prevalência de agenesias dentárias em indivíduos portadores de fissura transforame incisivo unilateral, CARRARA 15, em 2000, examinou 477 pacientes regularmente matriculados no HRAC - USP, brasileiros, leucodermas, de ambos os gêneros, na faixa etária de 5 a 14 anos. Realizou exames clínico e radiográfico. Os indivíduos do gênero feminino mostraram para todos os dentes permanentes, uma idade média de erupção menor em relação aos indivíduos do gênero masculino. $O$ incisivo lateral e o canino, ambos superiores e adjacentes à fissura, apresentaram idade média de erupção significantemente maior em relação aos seus homólogos do lado não fissurado. A prevalência de agenesias dentárias foi de $63,86 \%$ para o gênero feminino e de $50,5 \%$ para o gênero masculino. Os indivíduos portadores de fissura apresentaram idade média de erupção maior em relação aos indivíduos não fissurados para a maioria dos dentes permanentes, em todos os hemi-arcos e em ambos os gêneros.

\subsection{Fatores de ordem local}

Estudando a seqüência de erupção dos dentes permanentes, LO; MOYERS63, em 1953, afirmaram que a presença de uma área patológica extensa ao nível das raízes dos dentes decíduos e com conseqüente perda óssea significante é, em alguns casos, suficiente para que o dente sucessor permanente irrompa mais rápido do que o seu correspondente no lado oposto do arco dentário. 
Com o propósito de avaliar os efeitos da perda prematura dos molares decíduos na erupção dos pré-molares correspondentes, POSEN94, em 1965, analisou os modelos de estudo e radiografias oblíquas de 62 pacientes submetidos à extração de molares decíduos e de 25 pacientes controle não submetidos a extrações, todos do Centro de Pesquisa Ortodôntica de Burlington. A erupção dos pré-molares apresentourse fortemente afetada pela perda prematura dos molares decíduos. O autor concluiu que há um atraso da erupção dos pré-molares em jovens que apresentaram perda prematura de molares decíduos nas idades de 4 e 5 anos; após a idade de 5 anos, houve uma gradual redução no atraso da erupção do pré-molar e um gradual aumento na velocidade de erupção até a idade de 8 anos ser alcançada; nas idades de 8,9 e 10 anos, houve uma grande aceleração da erupção do pré-molar em decorrência da perda prematura de molares decíduos.

GRABER ${ }^{38}$, em 1965, ressaltou que se não houver espaço adequado nos arcos dentários, pode ocorrer um atraso na erupção dos dentes permanentes ou os mesmos irrompem por lingual ou rotados. Às vezes, um traumatismo pode causar uma variação na seqüência de erupção dos dentes permanentes.

Em 1989, LOEVY64 avaliou radiograficamente o efeito da extração de molares decíduos em 33 pacientes de diferentes idades no desenvolvimento dos pré-molares sucessores, utilizando o dente do lado oposto (sem extração) como controle. A análise desses dados demonstrou que condições locais, como a extração e a terapia endodôntica, podem influenciar a erupção dentária e que a erupção do dente sucessor pode ocorrer precocemente, quando o dente decíduo tiver sido extraído ou submetido à pulpotomia, independentemente da maturação desse dente sucessor (sic). Apesar dos fatores ambientais influenciarem a erupção, eles parecem exercer pouca influência na maturação dentária.

No ano seguinte, BENGSTON; BENGSTON 6 estudaram a relação entre a mortificação pulpar de dentes decíduos e o desvio na erupção dos seus sucessores. Para tal, utilizaram radiografias periapicais obtidas pela técnica do 
"cone longo" de 103 molares decíduos inferiores, juntamente com os seus dentes sucessores. Os autores concluíram que, somente a condição de mortificação pulpar de molares decíduos não apresenta a capacidade de provocar alteração no trajeto de erupção dos seus sucessores e que existe uma relação direta entre o desvio do trajeto de erupção do germe do dente permanente e a ocorrência de abscesso (com rarefação óssea) no antecessor decíduo. Dos 65 germes que sofreram desvio na erupção, 61 eram sucessores de dentes decíduos portadores de abscessos, o que corresponde a $94,15 \%$ dos dentes que alteraram o seu trajeto eruptivo.

De acordo com BURDI; MOYERS12 (1991), os distúrbios mecânicos, bem como os processos patológicos localizados, podem alterar o plano genético de erupção. As lesões periapicais, as pulpites e a pulpotomia de um molar decíduo podem acelerar a erupção do pré-molar sucessor. Se o dente decíduo for extraído depois que o sucessor permanente tenha iniciado os movimentos ativos de erupção, o dente irromperá precocemente. Se o dente decíduo for extraído antes do início dos movimentos eruptivos do permanente (antes da formação da raiz), é bem provável que o dente permanente atrase sua erupção, pois, o processo alveolar pode voltar a se formar sobre o dente sucessor, tornando a erupção mais difícil e lenta. Assim, os possíveis efeitos da extração do dente decíduo sobre a erupção do seu sucessor relacionam-se com o estágio de desenvolvimento dos dentes permanentes. Também pode ser observado que 0 apinhamento dos dentes permanentes afeta, ligeiramente, sua velocidade de mineralização e erupção. Além desses fatores, o trauma nos dentes decíduos, especialmente nos dentes anteriores, pode prejudicar 0 irrompimento normal do sucessor permanente.

Nesse mesmo ano, LOEVY; CRAWFORD66 realizaram um estudo com o objetivo de avaliar a época de erupção dos pré-molares superiores e inferiores após a pulpotomia dos dentes antecessores, utilizando o lado oposto como controle. A amostra consistiu de radiografias seriadas de molares decíduos de 14 crianças do gênero masculino e 13 do feminino, com idades na época do tratamento pulpar variando entre 3,23 e 9,00 anos, sendo a idade média 6,42 anos. A erupção dos dentes sucessores ocorreu mais cedo em 15 casos, 
aproximadamente ao mesmo tempo em 9 casos e mais tarde em 3 casos, em relação aos dentes controle, dependendo das características individuais do paciente.

Com o objetivo de identificar a prevalência de anquilose de molares decíduos, COUTINHO; SOUZA22, em 1994, avaliaram radiograficamente 3775 pacientes de 4 a 12 anos de idade, de ambos os gêneros, atendidos na Clínica de Odontopediatria da FO-UFRJ entre os anos de 1981 e 1990. Os autores concluíram que: a prevalência de anquilose de molares decíduos encontrada foi de 4\%, sem diferença entre os gêneros; a maior prevalência foi a de anquilose única, em $43 \%$ dos casos. O dente mais afetado foi o primeiro molar decíduo inferior (53\%) e o arco inferior apresentou a maior prevalência (90\%), sem diferença quanto ao hemi-arco. A ocorrência de agenesia, alterações no grau de formação radicular e padrão de erupção do sucessor permanente não foi diretamente relacionada com a anquilose.

No ano de 1995, VALLADARES-NETO; SILVA; KAADI119 realizaram uma revisão da literatura a respeito dos agentes etiológicos atinentes ao retardo eruptivo. Admite-se que a seqüência e a época de erupção apresentam um período bem variável. No entanto, a precocidade ou retardo extremos, bem como a seqüência atípica, podem influenciar o futuro desenvolvimento da dentição; sendo assim, odontopediatras e ortodontistas devem dispensar especial atenção em relação a esses fenômenos. A erupção dentária, quando anormalmente tardia e ausente, pode ser atribuída a fatores gerais ou locais. Os fatores locais apresentam desvios cronológicos e assimetrias apenas do dente afetado. Esse desvio cronológico anormal, em relação ao seu homólogo, supera os seis meses. O retardo eruptivo localizado, associado à erupção ectópica, pode ter origem traumática, desenvolvimental, obstrutiva ou idiopática. Os dentes supranumerários constituem-se nos principais fatores etiológicos locais relacionados ao retardo eruptivo ou não irrupção na região ântero-superior. No entanto, outros agentes etiológicos menos prevalentes, mas de relevância inegável, também concorrem para tal manifestação clínica. Entre eles encontram-se: traumatismo dentoalveolar, retenção prolongada de dentes decíduos, cisto dentígero, fibrose gengival, discrepância ósseo-dentária 
negativa, perda precoce de dentes decíduos e posição ectópica do dente na cripta de origem desenvolvimental. Sabe-se que a ausência congênita ou a trajetória ectópica de um dente permanente imprimem um processo de reabsorção de modo muito mais lento que o normal, por não participarem como elemento ativo no fenômeno rizólise. À sua vez, o traumatismo em dentes decíduos pode trazer marcas indeléveis ao desenvolvimento dos dentes permanentes sucessores. Isto se explica pela íntima relação anatômica entre as raízes dos dentes decíduos e a coroa do dente permanente sucessor localizado superiormente e palatinamente, separados apenas por uma delgada lâmina óssea. $O$ impacto de um trauma transmitido ao dente permanente pode deslocar o germe de sua trajetória normal, ou simplesmente alterar a fisiologia eruptiva, ou ainda, induzir a formação de uma anquilose dentoalveolar. Convém ressaltar que 0 movimento fisiológico também pode ficar comprometido, quando associado à inibição de formação radicular e dilaceração radicular.

No ano seguinte, COLL; SADRIAN ${ }^{19}$ avaliaram o sucesso a longo prazo dos procedimentos de pulpectomia em dentes decíduos, determinaram os fatores capazes de influenciar o sucesso ou insucesso desse procedimento e investigaram a existência de uma associação entre a pulpectomia e defeitos no esmalte ou alteração na erupção dos dentes sucessores. Os autores concluíram que: $77,7 \%$ dos dentes decíduos submetidos a pulpectomia obtiveram sucesso após 90,8 meses de controle; observourse defeitos de esmalte em 18,7\% dos dentes sucessores e estes estavam significantemente relacionados à quantia de reabsorção radicular pré-operatória; os índices de defeitos de esmalte nos dentes sucessores aos pulpectomizados não foram significantemente diferentes dos dentes controle não tratados; os incisivos pulpectomizados estavam associados a uma incidência de $20 \%$ de mordida cruzada anterior ou erupção palatina dos incisivos permanentes sucessores. Os molares pulpectomizados necessitaram ser extraídos em 21,6\% dos casos devido à erupção ectópica do pré-molar ou dificuldade de esfoliação; os dentes pulpectomizados raramente esfoliaram mais tarde do que o normal. Cerca de $36 \%$ dos dentes pulpectomizados necessitaram ser extraídos. 
JOHAL 51 , em 1997, se propôs a estudar os molares decíduos em infraoclusão. Acredita-se que, o mecanismo biológico pelo qual os molares decíduos se tornam em infra-oclusão é a anquilose de parte da superfície radicular com o osso alveolar circundante, durante o processo de remodelação associado com a reabsorção radicular. Apesar de o mecanismo exato que inicia o fenômeno não ser conhecido, diversas teorias têm sido propostas: predisposição genética, ausência do permanente sucessor, deficiência local do crescimento do osso alveolar, trauma e distúrbio do metabolismo local causando mudanças estruturais no ligamento periodontal. A mandíbula é muito mais afetada que a maxila. Como possíveis efeitos da infra-oclusão dos molares decíduos no desenvolvimento da oclusão, pode-se citar: atraso na esfoliação do molar decíduo, atraso na erupção do permanente sucessor ou impacção do mesmo, padrão de erupção anormal dos permanentes sucessores, rotação do dente sucessor, formação de cistos na região dos permanentes sucessores, perda de comprimento do arco dentário, sobreerupção do dente antagonista, inclinação dos dentes adjacentes, mordida aberta localizada e função anormal da língua, inibição do desenvolvimento ósseo vertical e crescimento do processo alveolar, deterioração da função mastigatória e o local torna-se potencial ao desenvolvimento de má oclusão.

Realizando uma revisão na literatura, LEITE; RODRIGUES61, em 1997, abordaram o tema da anquilose em dentes decíduos e o ilustraram por meio de dois casos clínicos. A anquilose pode ser considerada como interrupção do ritmo da erupção e do crescimento alveolar local. Sua etiologia é bastante complexa e pode estar relacionada a diversos fatores, como erupção ectópica do primeiro molar permanente, comprimindo o segundo molar decíduo para o interior do osso; pressão exercida pelos dentes vizinhos devido a espaço inadequado do arco; ausência congênita do dente permanente sucessor correspondente; tendência familiar, seguindo padrões hereditários. Concluindo, o profissional deve ter atenção redobrada com relação ao processo fisiológico da troca dos dentes, observando, nos exames clínicos e complementares, desvios do padrão tido como normal. A anquilose dentária, em especial dos molares decíduos, é uma das alterações observáveis. 


$$
\text { Em 1998, YONEMOCHI; NODA; SAKU126 examinaram }
$$

histopatologicamente e imunohistoquimicamente o opérculo gengival dos dentes com atraso eruptivo para determinar as possíveis causas da falha na erupção dentária. O material consistiu de 61 espécimes cirúrgicos de tecido gengival, que cobriam as coroas de dentes com retardo eruptivo, coletados de 58 pacientes. Esses pacientes não apresentavam causas clínicas óbvias do retardo eruptivo, como falta de espaço para o dente em erupção, anquilose dentária, entre outras. Foram examinados como controle 17 amostras de tecido gengival, que recobriam dentes não irrompidos que foram removidos por outras razões que não fosse o retardo eruptivo, e 12 amostras de tecido do folículo dentário de dentes impactados. Os autores concluíram que a presença de hamartomas pericoronários, que apresentam dois tipos de variações histológicas - hiperplasia mixofibrosa pericoronária e fibromatose ameloblástica infantil - bem como a fibrose gengival induzida por essas lesões, podem ser os principais fatores locais no atraso da erupção dentária.

Com o propósito de investigar a idade média e a seqüência de erupção dos dentes permanentes, considerando-se o efeito da perda prematura dos dentes antecessores decíduos, KOCHHAR; RICHARDSON57, em 1998, desenvolveram um estudo longitudinal com 276 indivíduos caucasianos, com idades variando entre 5 e 15 anos. Compararam as idades médias de erupção em casos com e sem a perda prematura de dentes decíduos, entre o arco superior e o inferior, entre o lado esquerdo e o lado direito e entre indivíduos do gênero feminino e masculino. Os resultados mostraram que a perda prematura dos dentes decíduos retarda a erupção dos sucessores permanentes, com exceção dos pré-molares superiores em que a erupção foi mais acelerada. Os dentes permanentes inferiores irromperam mais cedo do que seus correspondentes superiores, com exceção dos pré-molares. Não houve diferença estatisticamente significante quando se considerou os lados direito e esquerdo. Indivíduos do gênero feminino apresentaram uma tendência de erupção em idades mais precoces do que indivíduos do gênero masculino, com exceção dos segundos molares, tanto do arco superior como do inferior. A seqüência de erupção: 6-1-2-4-3-5-7 no arco superior e 1-6-2-3-4-5-7 no arco inferior ocorreu em $16 \%$ dos casos no arco superior e $13 \%$ dos casos no arco 
inferior. Os autores ressaltam a precisão deste estudo por ser longitudinal, os indivíduos da amostra serem todos de etnia caucasiana e o fato do estudo ter levado em consideração o efeito da perda prematura dos dentes decíduos.

Pesquisando a prevalência da anquilose dentoalveolar em escolares do município de São Paulo, PEREIRA; RODRIGUES ${ }^{92}$, em 1999, examinaram 400 crianças, sem distinção de raça, na faixa etária dos 6 aos 11 anos. Os autores concluíram que a prevalência de crianças portadoras de molares decíduos com anquilose dentoalveolar foi de $8,3 \%$, sendo maior no gênero feminino; a prevalência de molares decíduos anquilosados foi maior no arco inferior, sendo o primeiro molar decíduo inferior o dente mais afetado. Torna-se importante um exame clínico cuidadoso para o diagnóstico e o tratamento correto da anquilose dentoalveolar, visto que esta pode causar vários problemas no desenvolvimento da dentição e da oclusão, como atraso na esfoliação do molar decíduo afetado, trajetória anormal de erupção do dente permanente sucessor, impacção ou rotação do permanente sucessor, bem como inclinação dos dentes adjacentes aos molares decíduos afetados e extrusão dos dentes antagonistas, entre outros.

\subsubsection{Relação entre erupção e mineralização dos dentes permanentes}

Ao relacionarem a erupção e a mineralização dos dentes permanentes, BURDI; MOYERS ${ }^{12}$, em 1991, afirmaram que a erupção consiste no processo de desenvolvimento que movimenta um dente desde a sua posição na cripta através do osso alveolar, até ocluir com seu antagonista na cavidade bucal. Durante a erupção dos dentes sucessores, muitas atividades ocorrem simultaneamente; o dente decíduo reabsorve-se, a raiz do dente permanente aumenta, o processo alveolar cresce em altura e o dente permanente se movimenta através do osso. Os dentes permanentes não iniciam os movimentos eruptivos até que suas coroas estejam completas. Passam pela crista do processo alveolar por estágios variados do desenvolvimento radicular. Assim, os movimentos eruptivos começam quando a formação da raiz se inicia. São necessários de 2 a 5 anos para que os dentes posteriores alcancem a crista alveolar depois de completarem suas coroas e 12 a 20 meses para que 
alcancem a oclusão, depois de atingirem a margem alveolar. Geralmente, as raízes se completam poucos meses depois de alcançada a oclusão. Os movimentos eruptivos não se correlacionam bem com a quantidade do alongamento radicular. Os dentes irrompem, permitindo o crescimento das raízes e, portanto, o alongamento radicular poderia ser melhor considerado como resultado da erupção, e não como uma de suas causas. 
3. Proposiçãao 


\section{PROPOSIÇÃO}

Propõe-se neste trabalho comparar em indivíduos brasileiros, leucodermas, de ambos os gêneros:

. o estágio de maturação dos dentes permanentes na idade de 8 anos entre os jovens com padrões de crescimento predominantemente vertical e predominantemente horizontal, classificados por meio dos valores das grandezas cefalométricas SN.GoGn, NS.Gn, FMA e AFAI, tendo como referência os valores do Atlas de Crescimento Craniofacial73;

- a idade média e a seqüência média de erupção dos dentes permanentes entre os jovens com padrões de crescimento predominantemente vertical e predominantemente horizontal, na faixa etária dos 5 aos 13 anos. 


\section{Materiale Métodos}




\section{MATERIAL E MÉTODOS}

\subsection{Material}

\subsection{1 - Seleção da amostra}

Para o presente estudo retrospectivo, utilizou-se parte da amostra longitudinal da Disciplina de Ortodontia da Faculdade de Odontologia de Bauru - Universidade de São Paulo, composta por um total de 256 jovens brasileiros, descendentes de mediterrâneos, examinados anualmente dos 3 aos 18 anos de idade, onde foram obtidas telerradiografias em norma lateral, radiografias panorâmicas, modelos de gesso e medição de peso e altura. Esses dados foram coletados no período de 1967 e 1987.

Inicialmente, selecionoutse telerradiografias em norma lateral de 111 jovens ( 56 do gênero feminino e 55 do gênero masculino) na idade de 8 anos (idade mínima: 8,00 anos; idade máxima: 8,92 anos; idade média: 8,49 anos), a fim de classificar o tipo de padrão de crescimento de cada indivíduo. Os valores das quatro grandezas cefalométricas consideradas (SN.GoGn, NS.Gn, FMA e AFAl) foram somados. Os 30 jovens ( 15 do gênero masculino e 15 do feminino) que apresentaram os maiores valores foram selecionados para constituir 0 Grupo Vertical, e os 30 jovens ( 15 do gênero masculino e 15 do feminino) que apresentaram os menores valores da soma das quatro grandezas cefalométricas, foram selecionados para constituir o Grupo Horizontal. Selecionou-se radiografias panorâmicas obtidas aos 8 anos de idade dos jovens pertencentes ao Grupo Vertical e ao Grupo Horizontal, com o intuito de se avaliar a maturação dos dentes permanentes.

Da amostra de 111 jovens previamente classificados de acordo com o padrão de crescimento facial, selecionou-se 533 pares de modelo de gesso de 97 jovens, na faixa etária dos 5 aos 13 anos de idade, para a avaliação da cronologia e seqüência de erupção dos dentes permanentes. Esses modelos de gesso foram selecionados de maneira a preencher 30 pares de modelos em cada idade estudada, em cada grupo (Tabela 1). Quando não foi possível obter 
30 pares de modelos em uma determinada idade, selecionourse um número máximo possível de pares de modelos de gesso, sem distanciar dos 30 pares almejados inicialmente. Os pares de modelos de gesso também foram distribuídos em dois grupos. O primeiro grupo, denominado de Grupo Vertical, ficou constituído por modelos de gesso dos jovens que apresentassem um predomínio do vetor de crescimento vertical e o segundo grupo, denominado Grupo Horizontal, ficou constituído por modelos de gesso dos jovens que apresentassem um predomínio do vetor de crescimento horizontal.

TABELA 1 - Número de pares de modelos avaliados em cada idade, na faixa etária dos 5 aos 13 anos de idade, distribuídos de acordo com 0 padrão de crescimento.

\begin{tabular}{|c|c|c|c|c|c|c|c|c|c}
\hline & $\mathbf{5}$ & $\mathbf{6}$ & $\mathbf{7}$ & $\mathbf{8}$ & $\mathbf{9}$ & $\mathbf{1 0}$ & $\mathbf{1 1}$ & $\mathbf{1 2}$ & $\mathbf{1 3}$ \\
\hline Vertical & 30 & 30 & 30 & 30 & 30 & 30 & 30 & 28 & 25 \\
\hline Horizontal & 30 & 30 & 30 & 30 & 30 & 30 & 30 & 30 & 30 \\
\hline
\end{tabular}

Os critérios básicos utilizados para a seleção da amostra foram a presença de todos os dentes permanentes (com exceção dos terceiros molares) nas radiografias panorâmicas de todos os jovens, independentemente dos estágios de desenvolvimento em que esses dentes se encontravam e ausência de anodontias ou dentes supranumerários. Não se considerou a presença de más oclusões.

\subsection{2 - Material para elaboração do traçado}

Os traçados cefalométricos foram realizados em folhas de papel "Ultraphan" de 0,07mm de espessura e 17,5cm de largura e comprimento, adaptadas nas telerradiografias. Os traçados foram efetuados manualmente sobre o negatoscópio pela pesquisadora, utilizando lapiseira com grafite $0,5 \mathrm{~mm}$, em uma sala obscurecida. 


\section{2 - Métodos}

\subsection{1 - Classificação do Padrão de Crescimento Facial}

Utilizou-se 111 telerradiografias em norma lateral obtidas de acordo com as normas técnicas preconizadas pela Disciplina de Radiologia da FOB - USP. O fator de magnificação nas telerradiografias foi de $6 \%$.

\subsubsection{1 - Traçado Anatômico}

Foram delimitadas as seguintes estruturas anatômicas (Figura 1):

- perfil mole;

- perfil do osso frontal e dos ossos nasais;

- sela túrcica;

- meato acústico externo;

- órbita;

- maxila;

- contorno da mandíbula e côndilo;

- incisivos centrais e primeiros molares permanentes superiores e inferiores.

Para todas as estruturas bilaterais efetuourse o traçado médio.

\subsubsection{2 - Pontos de Referência}

Os pontos de referência anatômicos foram demarcados seguindo as especificações do Atlas de Crescimento Craniofacial73 (Figura 1):

1. S (sela túrcica): ponto localizado no centro da concavidade óssea da sela túrcica;

2. $N$ (násio): interseção da sutura internasal com a sutura frontonasal;

3. Po (pório): ponto mais superior do meato acústico externo;

4. Or (orbitário): ponto mais inferior da margem infraorbitária; 
5. Go (gônio): ponto mais póstero-inferior do contorno do ângulo goníaco;

6. Gn (gnátio): ponto mais ântero-inferior do contorno do mento ósseo;

7. Me (mentoniano): ponto mais inferior do contorno da sínfise mentoniana;

8. ENA (espinha nasal anterior): ponto mais anterior do palato duro; interseção da parte ântero-superior da maxila com o assoalho da fossa nasal.

\subsubsection{3- Linhas e Planos (Figura 1)}

1. Linha SN: do ponto sela túrcica ao násio;

2. Plano horizontal de Francfort: do ponto pório ao orbitário;

3. GoGn (plano mandibular): do ponto gônio ao gnátio;

4. GoMe (plano mandibular): do ponto gônio ao mentoniano;

5. Linha SGn (eixo $Y$ de crescimento): vai do ponto sela túrcica em direção ao ponto gnátio, interrompendo-se o traçado antes da coroa do molar superior.

\subsubsection{4- Grandezas Cefalométricas Esqueléticas (Figura 1)}

1- SN.GoGn: ângulo formado pela linha SN e o plano mandibular GoGn. Define a inclinação da borda inferior da mandíbula com a base do crânio;

2- NS.Gn: ângulo formado entre os pontos násio, sla túrcica e gnátio. Define a resultante vetorial de crescimento da mandíbula relacionada com a base do crânio;

3- FMA: ângulo formado pelos planos horizontal de Francfort e mandibular GoMe. Define a orientação do padrão de crescimento facial;

4- AFAI (ENA-Me): distância entre os pontos espinha nasal anterior e mentoniano. Indica a altura do terço inferior da face. 
Utilizou-se como referência para os valores normativos das grandezas cefalométricas consideradas, aqueles propostos pelo Atlas de Crescimento Craniofacial $^{73}$ na idade de 8 anos, que são:

\begin{tabular}{lcccc} 
& \multicolumn{2}{c}{ Gênero masculino } & \multicolumn{2}{c}{ Gênero feminino } \\
& Média & D.P. & Média & D.P. \\
SN.GoGn & $36,3^{\circ}$ & $4,8^{\circ}$ & $36,2^{\circ}$ & $4,5^{\circ}$ \\
NS.Gn & - & - & - & - \\
FMA & $32,8^{\circ}$ & $4,9^{\circ}$ & $31,7^{\circ}$ & $4,6^{\circ}$ \\
AFAI & $64,7 \mathrm{~mm}$ & $4,1 \mathrm{~mm}$ & $61,3 \mathrm{~mm}$ & $3,6 \mathrm{~mm}$
\end{tabular}




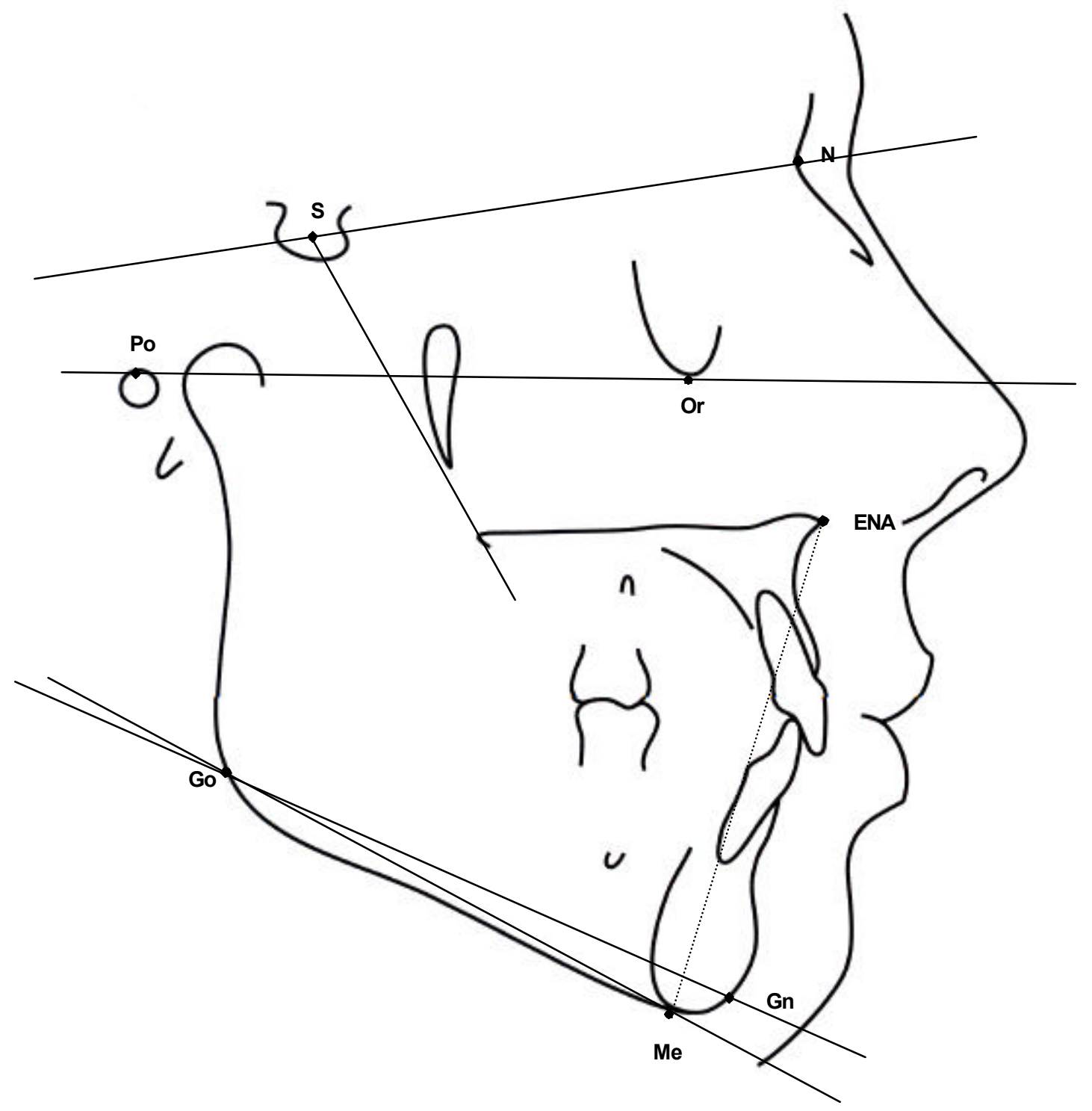

FIGURA 1 - Traçado anatômico com os pontos de referência, linhas e planos. 


\subsection{2 - Avaliação da Maturação Dentária}

Avaliourse 60 radiografias panorâmicas obtidas aos 8 anos de idade, dos jovens selecionados por meio das telerradiografias, a partir do tipo de padrão de crescimento. Foram selecionadas as radiografias panorâmicas dos 30 jovens que apresentaram o maior predomínio do vetor de crescimento vertical ( 15 do gênero masculino e 15 do gênero feminino) e dos 30 jovens que apresentaram o maior predomínio do vetor de crescimento horizontal (15 do gênero masculino e 15 do gênero feminino), constituindo assim, o Grupo Vertical e o Grupo Horizontal, respectivamente. Por meio destas radiografias, avaliourse em um estudo duplo cego os estágios de mineralização dos dentes permanentes do quadrante inferior esquerdo, do incisivo central ao segundo molar, de acordo com o método proposto por DEMIRJIAN; GOLDSTEIN; TANNER²6, em 1973.

Cada um dos 7 dentes avaliados foi classificado de acordo com os estágios de desenvolvimento dos dentes permanentes, distribuídos de $\mathrm{A}$ a $\mathrm{H}$. Em casos limítrofes, onde determinados dentes apresentaram características intermediárias, optourse pelos estágios mais precoces ${ }^{26}$. Esta classificação foi realizada pelo método visual e comparativo, a olho nu, conforme recomendado por DEMIRJIAN; GOLDSTEIN; TANNER ${ }^{26}$. Os estágios de desenvolvimento serão descritos a seguir e ilustrados na Figura 2:

A. observa-se o início de mineralização na margem superior da cripta, em forma de cone invertido, ou cones invertidos nos casos de dentes multirradiculares. Não há fusão desses pontos de mineralização;

B. fusão dos pontos de mineralização, formando uma ou algumas cúspides, que se unem proporcionando uma superfície oclusal regular;

C. a) a formação do esmalte apresenta-se completa na superfície oclusal. Observa-se sua extensão e convergência em direção àregião cervical;

b) observa-se o início da deposição dentinária; 
c) o contorno da câmara pulpar apresenta uma forma curva na borda oclusal;

D. a) a formação da coroa apresenta-se completa até a junção cemento-esmalte;

b) o teto da câmara pulpar dos dentes unirradiculares apresentam uma curvatura bem definida, mostrando-se côncava na direção da região cervical. Nos molares a câmara pulpar apresenta uma forma trapezoidal;

c) observa-se o início da formação radicular em forma de espícula;

E. - dentes unirradiculares:

a) as paredes da câmara pulpar apresentam agora formas bem definidas, cuja continuidade é interrompida pela presença dos cornos pulpares, que por sua vez apresentam-se mais largos do que no estágio anterior;

b) o comprimento radicular é menor do que a altura da coroa;

- molares:

a) observa-se 0 início da formação da bifurcação radicular ou pela presença de um ponto de mineralização ou pela presença de uma estrutura em forma semi-lunar;

b) o comprimento radicular continua menor do que a altura da coroa;

F. - dentes unirradiculares:

a) as paredes da câmara pulpar agora assemelham-se a um triângulo isósceles. O ápice termina em forma de funil;

b) o comprimento radicular torna-se igual ou maior do que a altura coronária; 
- molares:

a) a região calcificada da bifurcação evoluiu da forma semi- lunar para atribuir às raízes uma forma mais definida;

b) o comprimento radicular apresenta-se igual ou maior do que a altura da coroa;

G. as paredes do canal encontram-se agora paralelas e sua região apical ainda encontra-se parcialmente aberta (raiz distal dos molares);

H. a) a região apical do canal radicular encontra-se completamente fechada (raiz distal dos molares);

b) a membrana periodontal apresenta uma espessura uniforme ao redor da raiz e do ápice radicular.

Cada um dos 7 dentes permanentes inferiores do lado esquerdo foi classificado de acordo com o estágio de desenvolvimento no qual se encontra e para cada estágio de desenvolvimento há um escore correspondente, conforme expresso na Tabela 2. A soma desses 7 escores forneceu um escore de maturidade dentária.

O escore de maturidade dentária pode ser convertido diretamente em idade dentária, utilizando-se uma tabela apropriada para o gênero masculino e uma para o gênero feminino (Tabelas 3 e 4). A idade dentária é definida como a idade estimada de um indivíduo, baseada no nível de mineralização dentária durante o processo de desenvolvimento 40 e foi utilizada neste estudo, por ser um parâmetro universal e de simples emprego.

Posteriormente, comparourse a idade dentária média obtida em cada grupo com a idade cronológica média de cada grupo, a fim de avaliar se os jovens com predomínio de um determinado padrão de crescimento facial apresentam a idade dentária mais avançada ou mais atrasada em relação à idade cronológica. Uma idade dentária mais avançada do que a idade cronológica denotaria uma maturação dentária mais precoce, e uma idade 
dentária mais atrasada em relação à idade cronológica representaria uma maturação dentária mais atrasada.

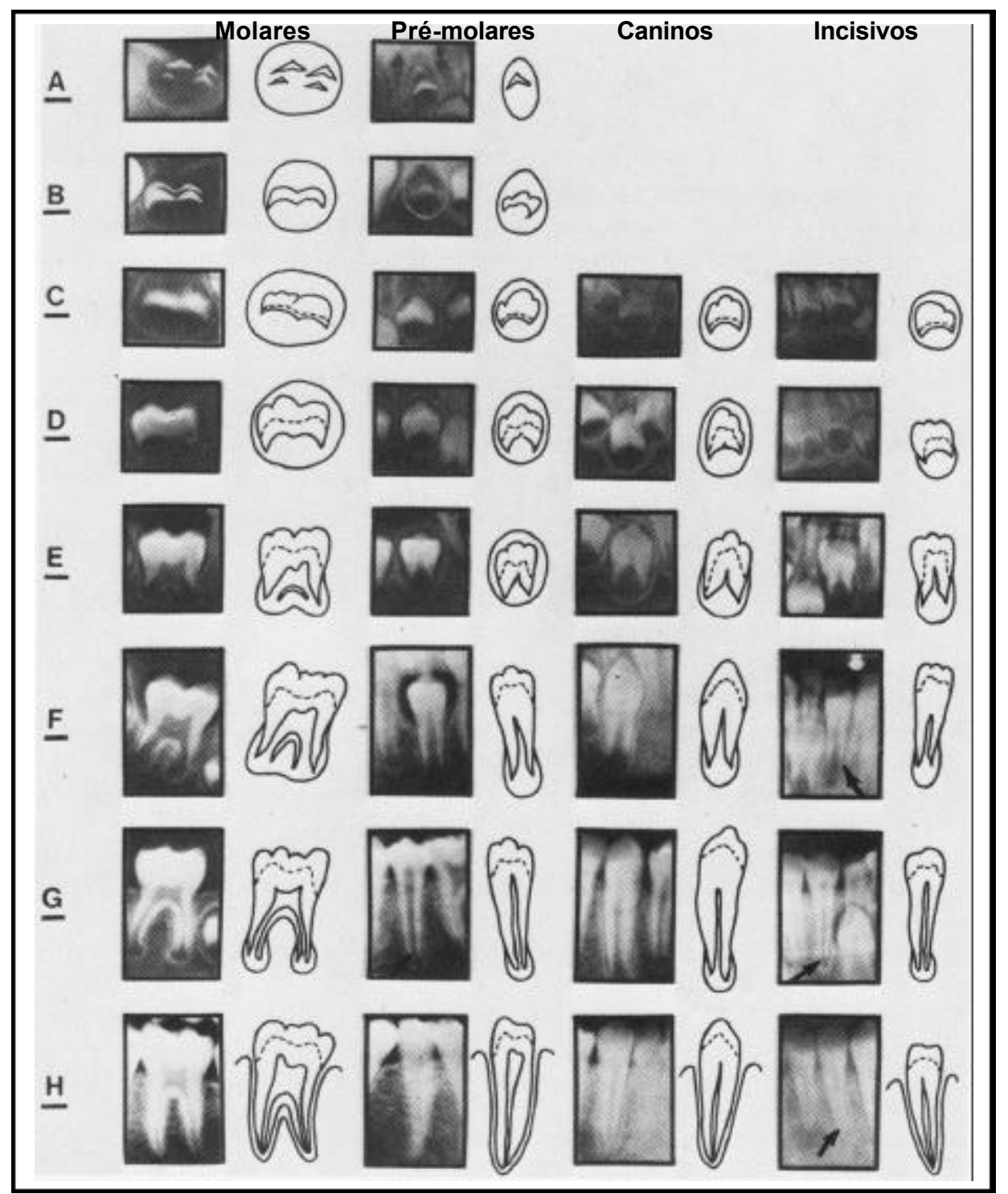

FIGURA 2 - Estágios de desenvolvimento dos dentes permanentes. Reproduzido de DEMIRJIAN; GOLDSTEIN; TANNER ${ }^{26}$. 
TABELA 2 - Escores de maturidade correspondentes aos estágios de desenvolvimento dos dentes permanentes, entre os gêneros 26 .

\begin{tabular}{|c|c|c|c|c|c|c|c|c|c|}
\hline $\bar{M}$ & ESTÁGIOS & $\mathbf{A}$ & $\bar{B}$ & $\mathbf{C}$ & $\bar{D}$ & $E$ & $F$ & $\mathbf{G}$ & $\mathrm{H}$ \\
\hline \multirow{7}{*}{$\begin{array}{l}\text { A } \\
\text { S } \\
\text { C } \\
U \\
\text { L } \\
\text { I } \\
\mathbf{N} \\
\mathbf{O}\end{array}$} & Dente 37 & 2,1 & 3,5 & 5,9 & 10,1 & 12,5 & 13,2 & 13,6 & 15,4 \\
\hline & Dente 36 & & & 0,0 & 8,0 & 9,6 & 12,3 & 17,0 & 19,3 \\
\hline & Dente 35 & 1,7 & 3,1 & 5,4 & 9,7 & 12,0 & 12,8 & 13,2 & 14,4 \\
\hline & Dente 34 & & 0,0 & 3,4 & 7,0 & 11,0 & 12,3 & 12,7 & 13,5 \\
\hline & Der & & & 0,0 & 3,5 & 7,9 & 10,0 & 11,0 & 11,9 \\
\hline & Dente 32 & & & 0,0 & 3,2 & 5,2 & 7,8 & 11,7 & 13,7 \\
\hline & Del & & & & 0,0 & 1,9 & 4,1 & 8,2 & 11,8 \\
\hline \multirow{8}{*}{$\begin{array}{c}\mathbf{F} \\
\text { E } \\
\text { M } \\
\text { I } \\
\mathbf{N} \\
\text { I } \\
\text { N } \\
\text { O }\end{array}$} & EST & $\mathbf{A}$ & B & C & D & $E$ & $\mathbf{F}$ & $\mathbf{G}$ & H \\
\hline & Den & 2,7 & 3,9 & 6,9 & 11,1 & 13,5 & 14,2 & 14,5 & 15,6 \\
\hline & Der & & & 0,0 & 4,5 & 6,2 & 9,0 & 14,0 & 16,2 \\
\hline & Den & 1,8 & 3,4 & 6,5 & 10,6 & 12,7 & 13,5 & 13,8 & 14,6 \\
\hline & Der & & 0,0 & 3,7 & 7,5 & 11,8 & 13,1 & 13,4 & 14,1 \\
\hline & Den & & & 0,0 & 3,8 & 7,3 & 10,3 & 11,6 & 12,4 \\
\hline & Den & & & 0,0 & 3,2 & 5,6 & 8,0 & 12,2 & 14,2 \\
\hline & Dente 31 & & & & 0,0 & 2,4 & 5,1 & 9,3 & 12,9 \\
\hline
\end{tabular}


TABELA 3 - Conversão do escore de maturidade dentária em idade dentária (baseada nos 7 dentes permanentes inferiores do lado esquerdo) para o gênero masculino ${ }^{26}$.

\begin{tabular}{|c|c|c|c|c|c|c|c|}
\hline IDADE & ESCORE & IDADE & ESCORE & IDADE & ESCORE & IDADE & ESCORE \\
\hline 3,0 & 12,4 & 6,0 & 33,6 & 9,0 & 83,6 & 12,0 & 94,0 \\
\hline, 1 & 12,9 & 1 & 34,7 &, 1 & 84,3 &, 1 & 94,2 \\
\hline , 2 & 13,5 & ,2 & 35,8 & , 2 & 85,0 & ,2 & 94,4 \\
\hline ,3 & 14,0 & 3 & 36,9 & ,3 & 85,6 & ,3 & 94,5 \\
\hline, 4 & 14,5 & 4 & 38,0 &, 4 & 86,2 &, 4 & 94,6 \\
\hline, 5 & 15,0 &, 5 & 39,2 &, 5 & 86,7 &, 5 & 94,8 \\
\hline 6 & 15,6 &, 6 & 40,6 & 6 & 87,2 & 6 & 95,0 \\
\hline, 7 & 16,2 & 7 & 42,0 &, 7 & 87,7 &, 7 & 95,1 \\
\hline, 8 & 17,0 & 8 & 43,6 &, 8 & 88,2 & 8 & 95,2 \\
\hline, 9 & 17,6 & 9 & 45,1 & ,9 & 88,6 &, 9 & 95,4 \\
\hline 4,0 & 18,2 & 7,0 & 46,7 & 10,0 & 89,0 & 13,0 & 95,6 \\
\hline , 1 & 18,9 & 1 & 48,3 & ,1 & 89,3 & , 1 & 95,7 \\
\hline ,2 & 19,7 & ,2 & 50,0 & ,2 & 89,7 & ,2 & 95,8 \\
\hline , 3 & 20,4 & ,3 & 52,0 & ,3 & 90,0 & ,3 & 95,9 \\
\hline, 4 & 21,0 & 4 & 54,3 &, 4 & 90,3 & 4 & 96,0 \\
\hline, 5 & 21,7 &, 5 & 56,8 &, 5 & 90,6 &, 5 & 96,1 \\
\hline 6 & 22,4 & 6 & 59,6 & 6 & 91,0 & 6 & 96,2 \\
\hline, 7 & 23,1 &, 7 & 62,5 &, 7 & 91,3 &, 7 & 96,3 \\
\hline ,8 & 23,8 & 8 & 66,0 & 8 & 91,6 & 8 & 96,4 \\
\hline 9 & 24,6 & 9 & 69,0 &, 9 & 91,8 & 9 & 96,5 \\
\hline 5,0 & 25,4 & 8,0 & 71,6 & 11,0 & 92,0 & 14,0 & 96,6 \\
\hline, 1 & 26,2 & , & 73,5 & , 1 & 92,2 &, 1 & 96,7 \\
\hline ,2 & 27,0 & ,2 & 75,1 & , 2 & 92,5 & ,2 & 96,8 \\
\hline, 3 & 27,8 & 3 & 76,4 & ,3 & 92,7 & ,3 & 96,9 \\
\hline, 4 & 28,6 & 4 & 77,7 &, 4 & 92,9 &, 4 & 97,0 \\
\hline, 5 & 29,5 &, 5 & 79,0 &, 5 & 93,1 &, 5 & 97,1 \\
\hline 6 & 30,3 & ,6 & 80,2 & ,6 & 93,3 & 6 & 97,2 \\
\hline ,7 & 31,1 & 7 & 81,2 &, 7 & 93,5 &, 7 & 97,3 \\
\hline 8 & 31,8 & 8 & 82,0 & 8 & 93,7 & 8 & 97,4 \\
\hline 9 & 32,6 &, 9 & 82,8 & 9 & 93,9 &, 9 & 97,5 \\
\hline
\end{tabular}


TABELA 4 - Conversão do escore de maturidade em idade dentária (baseada nos 7 dentes permanentes inferiores do lado esquerdo) para o gênero feminino 26 .

\begin{tabular}{r|c|r|r|r|r|r|r}
\hline IDADE & ESCORE & IDADE & ESCORE & IDADE & ESCORE & IDADE & ESCORE \\
\hline 3,0 & 13,7 & 6,0 & 38,0 & 9,0 & 87,2 & 12,0 & 96,3 \\
\hline, 1 & 14,4 &, 1 & 39,1 &, 1 & 87,8 &, 1 & 96,4 \\
\hline, 2 & 15,1 &, 2 & 40,2 &, 2 & 88,3 &, 2 & 96,5 \\
\hline, 3 & 15,8 &, 3 & 41,3 &, 3 & 88,8 &, 3 & 96,6 \\
\hline, 4 & 16,6 &, 4 & 42,5 &, 4 & 89,3 &, 4 & 96,7 \\
\hline, 5 & 17,3 &, 5 & 43,9 &, 5 & 89,8 &, 5 & 96,8 \\
\hline, 6 & 18,0 &, 6 & 45,2 &, 6 & 90,2 &, 6 & 96,9 \\
\hline, 7 & 18,8 &, 7 & 46,7 &, 7 & 90,7 &, 7 & 97,0 \\
\hline, 8 & 19,5 &, 8 & 48,0 &, 8 & 91,1 &, 8 & 97,1 \\
\hline, 9 & 20,3 &, 9 & 49,5 &, 9 & 91,4 &, 9 & 97,2 \\
\hline 4,0 & 21,0 & 7,0 & 51,0 & 10,0 & 91,8 & 13,0 & 97,3 \\
\hline, 1 & 21,8 &, 1 & 52,9 &, 1 & 92,1 &, 1 & 97,4 \\
\hline, 2 & 22,5 &, 2 & 55,5 &, 2 & 92,3 &, 2 & 97,5 \\
\hline, 3 & 23,2 &, 3 & 57,8 &, 3 & 92,6 &, 3 & 97,6 \\
\hline, 4 & 24,0 &, 4 & 61,0 &, 4 & 92,9 &, 4 & 97,7 \\
\hline, 5 & 24,8 &, 5 & 65,0 &, 5 & 93,2 &, 5 & 97,8 \\
\hline, 6 & 25,6 &, 6 & 68,0 &, 6 & 93,5 &, 6 & 98,0 \\
\hline, 7 & 26,4 &, 7 & 71,8 &, 7 & 93,7 &, 7 & 98,1 \\
\hline, 8 & 27,2 &, 8 & 75,0 &, 8 & 94,0 &, 8 & 98,2 \\
\hline, 9 & 28,0 &, 9 & 77,0 &, 9 & 94,2 &, 9 & 98,3 \\
\hline 5,0 & 28,9 & 8,0 & 78,8 & 11,0 & 94,5 & 14,0 & 98,3 \\
\hline, 1 & 29,7 &, 1 & 80,2 &, 1 & 94,7 &, 1 & 98,4 \\
\hline, 2 & 30,5 &, 2 & 81,2 &, 2 & 94,9 &, 2 & 98,5 \\
\hline, 3 & 31,3 &, 3 & 82,2 &, 3 & 95,1 &, 3 & 98,6 \\
\hline, 4 & 32,1 &, 4 & 83,1 &, 4 & 95,3 &, 4 & 98,7 \\
\hline, 5 & 33,0 &, 5 & 84,0 &, 5 & 95,4 &, 5 & 98,8 \\
\hline, 6 & 34,0 &, 6 & 84,8 &, 6 & 95,6 &, 6 & 98,9 \\
\hline, 7 & 35,0 &, 7 & 85,3 &, 7 & 95,8 &, 7 & 99,0 \\
\hline, 8 & 36,0 &, 8 & 86,1 &, 8 & 96,0 &, 8 & 99,1 \\
\hline 9 & 37,0 &, 9 & 86,7 &, 9 & 96,2 &, 9 & 99,1 \\
\hline & & & & & & & \\
\hline
\end{tabular}




\subsection{3 - Avaliação da Cronologia e Seqüência de Erupção Dentária}

Foram analisados 533 pares de modelos de gesso, de 97 dos 111 jovens selecionados previamente e classificados de acordo com o padrão de crescimento facial, com o intuito de avaliar a seqüência e a cronologia de erupção dos dentes permanentes, por meio de um estudo duplo cego, nos distintos grupos (Grupo Vertical e Grupo Horizontal). A seleção dos modelos foi realizada pelo método transversal, não havendo assim, a preocupação de analisar os modelos de um mesmo jovem em todas as idades pesquisadas. Por este método, as idades médias de erupção de cada dente são obtidas por meio da análise de vários modelos em uma mesma faixa etária, fornecendo desta maneira uma proporção de dentes irrompidos para cada idade. Desde que se utilize uma análise estatística adequada, este método pode ser utilizado com a mesma segurança do método longitudinal13,15.

A análise dos modelos de gesso foi realizada somente pela pesquisadora, evitando que houvesse variação no critério desta análise, segundo as interpretações pessoais.

Os dentes foram considerados irrompidos, quando qualquer porção da coroa estivesse visível nos modelos de gesso.

A idade média de erupção dos dentes permanentes foi obtida pelo método de Karber, modificado por HAYES; MANTEL 45 que recomendam a utilização deste método pela sua maior simplicidade e pelas boas estimativas conseguidas por meio dele. $O$ método de Karber deve ser empregado de maneira que as idades avaliadas cubram todo, ou praticamente todo o intervalo de erupção dos dentes permanentes ${ }^{15}$. Por isso, estabeleceu-se que a idade mínima dos jovens desta amostra deveria ser de 5 anos, pressupondo-se que nenhum dente permanente tivesse irrompido e a idade máxima de 13 anos, presumindo que todos os dentes permanentes, com exceção dos terceiros molares, estivessem irrompidos. 
O número de jovens selecionados para cada idade avaliada pode variar, desde que essa variação não seja acentuada13,15.

As fórmulas estatísticas utilizadas para o cálculo da idade média de erupção de cada dente $(X)$, desvio padrão da idade média (DP) e erro padrão da média (EP) foram elaboradas a partir da fórmula do método de Karber, com as devidas adaptações devido ao fato de se ter considerado intervalos anuais e não mensais. As fórmulas foram montadas no programa Excel.

$$
\begin{aligned}
& \mathrm{X}_{\mathrm{S}}=\text { número de anos + fator de correção } \\
& \mathrm{d}=1 \text { ano } \\
& S 1=\text { proporção acumulada de dentes irrompidos em cada ano } \\
& \text { S2= somatório da proporção de dentes irrompidos em todos os anos } \\
& \mathrm{n}=\text { número de dentes examinados em cada ano } \\
& \mathrm{p}=\text { número de dentes irrompidos em cada ano } \\
& n \\
& p+=p \text { do ano anterior }+p \text { do ano atual } \\
& X=\text { d. }\left(X_{S}-S 1+0,5\right) \\
& D P=\sqrt{\frac{2 . S 2-S 1 \cdot(S 1+1)-0,25}{1 d^{2}}} \\
& E P=p \cdot(1-p) \\
& \mathrm{n}-1
\end{aligned}
$$

\subsection{4 - Análise estatística}

\subsubsection{1 - Erro do método}

Para a avaliação do erro intra-examinador nas mensurações dos traçados cefalométricos, após 3 semanas da primeira medição foram traçadas e medidas novamente 20 telerradiografias, selecionadas aleatoriamente dentre 
as 111 existentes na amostra. Determinou-se o erro casual pela fórmula proposta por DAHLBERG 23 : $\mathrm{Se}^{2}=\Sigma \mathrm{d}^{2} / 2 \mathrm{n}$, onde $\mathrm{Se}^{2}$ representa o erro de Dahlberg; $\Sigma \mathrm{d}^{2}$ corresponde ao somatório dos quadrados das diferenças entre as primeiras e segundas medições e $2 n$ representa o dobro do número de casos em que as medidas foram repetidas. A obtenção dos erros sistemáticos procedeu-se pela aplicação do teste t pareado de acordo com HOUSTON47 (1983).

Posteriormente, verificou-se o erro intra-examinador na obtenção das idades dentárias, onde 20 radiografias panorâmicas escolhidas ao acaso dentre as 60 existentes na amostra foram avaliadas novamente, e classificouse os estágios de desenvolvimento para os dentes permanentes inferiores do lado esquerdo. Obteve-se a idade dentária para esses 20 jovens. Calculou-se o erro casual pela fórmula proposta por DAHLBERG ${ }^{23}$, e os erros sistemáticos foram obtidos pela aplicação do teste t pareado, de acordo com HOUSTON 47 .

No caso da avaliação dos modelos de gesso, não houve necessidade de avaliar o erro do método por ter se utilizado um critério simples e objetivo, que consistiu em verificar a presença ou não do dente permanente nos modelos de gesso.

\subsubsection{2 - Testes Estatísticos}

Para a utilização do teste $t$, torna-se necessário que a distribuição das variáveis seja normal, constatação esta obtida pelo teste de KolmogorovSmirnov, para cada uma das variáveis.

As características cefalométricas dos jovens do Grupo Vertical e do Grupo Horizontal foram demonstradas por meio de estatística básica.

As comparações entre os grupos foram realizadas por meio do teste $t$ independente. Os resultados foram considerados estatisticamente significantes para $\mathrm{p}<0,05$. 
5. Resultados 


\section{RESULTADOS}

Os resultados estão apresentados sob a forma de tabelas. Nas Tabelas 5 e 6 estão demonstrados os resultados dos erros casuais e sistemáticos da avaliação intra-examinador, para as grandezas cefalométricas utilizadas e para a obtenção da idade dentária, respectivamente.

Na Tabela 7 estão dispostos os resultados da comparação das variáveis cefalométricas estudadas entre os grupos Vertical e Horizontal. A Tabela 8 apresenta os resultados do teste $t$ independente, realizado para a comparação das idades dentárias (obtidas pela avaliação dos estágios de mineralização dos dentes permanentes inferiores do lado esquerdo), entre o Grupo Vertical e o Grupo Horizontal. A Tabela 9 representa a comparação entre a idade dentária e a idade cronológica nos grupos estudados por meio do teste t independente.

A Tabela 10 evidencia os resultados do teste $t$ independente entre as idades médias de erupção de todos os dentes permanentes, nos grupos Vertical e Horizontal. As Tabelas 11 e 12 apresentam os resultados da comparação das idades médias de erupção de cada dente permanente entre os gêneros, nos grupos Vertical e Horizontal, respectivamente. Nas Tabelas 13 e 14, foram realizadas comparações das idades médias de erupção entre jovens do gênero masculino, dos grupos Vertical e Horizontal e entre jovens do gênero feminino de ambos os grupos, respectivamente. Nas Tabelas 15 e 16 são apresentados os resultados da comparação das idades médias de erupção entre os hemi-arcos dentários, respectivamente no grupo Vertical e no grupo Horizontal. Finalmente, nas Tabelas 17 e 18 encontram-se os resultados da comparação das idades médias de erupção entre os arcos dentários, no Grupo Vertical e no Grupo Horizontal.

Os valores em negrito são estatisticamente significantes para $p<0,05$. 
TABELA 5 - Análise do erro intra-examinador. Apresentação dos erros casuais (Dahlberg), das médias, dos desvios padrão e nível de significância estatística dos erros sistemáticos (teste t pareado), entre os traçados cefalométricos repetidos.

\begin{tabular}{c|c|c|c|c|c|c|c}
\hline \multirow{2}{*}{ VARIÁVEIS } & \multicolumn{2}{|c|}{$\mathbf{1}^{\text {a }}$ MEDIÇÃO } & \multicolumn{2}{c|}{$\mathbf{2}^{\text {a }}$ MEDIÇÃO } & \multirow{2}{*}{ Dif. } & Dahlberg & p \\
\cline { 2 - 5 } & MÉDIA & D.P. & MÉDIA & D.P. & & & \\
\hline SN.GoGn & $\mathbf{3 6 , 4 0 0 0}$ & $\mathbf{3 , 7 8 9 2}$ & $\mathbf{3 5 , 8 7 5 0}$ & $\mathbf{3 , 4 7 8 8}$ & $\mathbf{0 , 5 2 5 0}$ & $\mathbf{0 , 8 1 7 7}$ & $\mathbf{0 , 0 3 8 7}$ \\
\hline NS.Gn & 69,5750 & 2,5969 & 69,3250 & 2,4240 & 0,2500 & 0,6422 & 0,2272 \\
\hline FMA & 29,9000 & 4,2134 & 29,7750 & 3,9419 & 0,1250 & 0,9968 & 0,7023 \\
\hline AFAI & 63,9250 & 3,8398 & 63,8250 & 4,0108 & 0,1000 & 0,7582 & 0,6876 \\
\hline
\end{tabular}

TABELA 6 - Análise do erro intra-examinador. Apresentação do erro casual (Dahlberg), das médias, dos desvios padrão e nível de significância estatística do erro sistemático entre as avaliações das idades dentárias.

\begin{tabular}{c|c|c|c|c|c|c|c}
\hline \multirow{2}{*}{ VARIÁVEL } & \multicolumn{2}{|c|}{$\mathbf{1}^{\text {a }}$ MEDIÇÃO } & \multicolumn{2}{c|}{$\mathbf{2}^{\text {a }}$ MEDIC̄ÃO } & Dif. & Dahlberg & p \\
\cline { 2 - 5 } & MÉDIA & D.P. & MÉDIA & D.P. & & & \\
\hline IDADE & 8,6750 & 0,7893 & 8,7450 & 0,7930 & $-0,0700$ & 0,1643 & 0,1845 \\
DENTÁRIA & 8,6750 & & & & & & \\
\hline
\end{tabular}


TABELA 7 - Resultados do teste $t$ independente entre as variáveis cefalométricas dos grupos Vertical e Horizontal.

\begin{tabular}{c|c|c|c|c|c|c}
\hline \multirow{2}{*}{ VARIÁVEIS } & \multicolumn{2}{|c|}{ VERTICAL } & \multicolumn{2}{c|}{ HORIZONTAL } & \multirow{2}{*}{ Dif. } & \multirow{2}{*}{} \\
\cline { 2 - 5 } & MÉDIA & D.P. & MÉDIA & D.P. & & \\
\hline SN.GoGn & 39,6333 & 2,8885 & 30,4000 & 3,3332 & 9,2333 & 0,0000 \\
\hline NS.Gn & 70,1500 & 2,7359 & 64,9167 & 2,6297 & 5,2333 & 0,0000 \\
\hline FMA & 33,8333 & 2,9634 & 24,2333 & 3,1231 & 9,6000 & 0,0000 \\
\hline AFAI & 65,9167 & 3,5673 & 58,5667 & 3,3752 & 7,3500 & 0,0000 \\
\hline
\end{tabular}

TABELA 8 - Resultados do teste $t$ independente entre a idade dentária dos grupos Vertical e Horizontal.

\begin{tabular}{c|c|c|c|c|c|c}
\hline \multirow{2}{*}{ VARIÁVEL } & \multicolumn{2}{|c|}{ VERTICAL } & \multicolumn{2}{c|}{ HORIZONTAL } & \multirow{2}{*}{ Dif. } & p \\
\cline { 2 - 5 } & MÉDIA & D.P. & MÉDIA & D.P. & & \\
\hline $\begin{array}{c}\text { IDADE } \\
\text { DENTÁRIA }\end{array}$ & $\mathbf{8 , 9 5 6 7}$ & $\mathbf{0 , 7 4 2 2}$ & $\mathbf{8 , 1 8 3 3}$ & $\mathbf{0 , 5 1 6 7}$ & $\mathbf{0 , 7 7 3 3}$ & $\mathbf{0 , 0 0 0 0}$
\end{tabular}

TABELA 9 - Resultados do teste t independente entre a idade cronológica e a idade dentária nos grupos Vertical e Horizontal.

\begin{tabular}{c|c|c|c|c|c|c}
\hline \multirow{2}{*}{ GRUPO } & \multicolumn{2}{|c|}{ IDADE } & \multicolumn{2}{c|}{ IDADE } & Dif. & p \\
& CRONOLÓGICA & \multicolumn{2}{c}{ DENTÁRIA } & & \\
\cline { 2 - 5 } & MÉDIA & D.P. & MÉDIA & D.P. & & \\
\hline VERTICAL & $\mathbf{8 , 5 0 6 7}$ & $\mathbf{0 , 3 0 7 3}$ & $\mathbf{8 , 9 5 6 7}$ & $\mathbf{0 , 7 4 2 2}$ & $\mathbf{- 0 , 4 5 0 0}$ & $\mathbf{0 , 0 0 3 2}$ \\
\hline HORIZONTAL & $\mathbf{8 , 4 8 0 0}$ & $\mathbf{0 , 2 9 5 2}$ & $\mathbf{8 , 1 8 3 3}$ & $\mathbf{0 , 5 1 6 7}$ & $\mathbf{0 , 2 9 6 7}$ & $\mathbf{0 , 0 0 8 3}$ \\
\hline
\end{tabular}


TABELA 10 - Idade média de erupção, desvio padrão e erro padrão de cada dente permanente nos grupos Vertical e Horizontal e o nível de significância estatística quando aplicado o teste $t$ independente entre os grupos.

\begin{tabular}{c|c|c|c|c|c|c|c}
\hline \multirow{2}{*}{ DENTE } & \multicolumn{3}{|c|}{ VERTICAL } & \multicolumn{3}{c|}{ HORIZONTAL } & \multirow{2}{*}{ p } \\
\cline { 2 - 7 } & MÉDIA & D.P. & E. P. & MÉDIA & D.P. & E. P & 0,2049 \\
\hline $\mathbf{1 7}$ & 11,9014 & 1,4781 & 0,1475 & 11,6333 & 1,5595 & 0,1514 & 0,2045 \\
\hline $\mathbf{1 6}$ & 6,2333 & 1,1742 & 0,1037 & 6,3000 & 1,2151 & 0,1115 & 0,6585 \\
\hline $\mathbf{1 5}$ & 10,6357 & 1,5624 & 0,1487 & 10,7666 & 1,6468 & 0,1559 & 0,5417 \\
\hline $\mathbf{1 4}$ & 10,1357 & 1,4810 & 0,1403 & 10,4333 & 1,5205 & 0,1326 & 0,1228 \\
\hline $\mathbf{1 3}$ & 11,0804 & 1,4994 & 0,1441 & 11,1333 & 1,5860 & 0,1533 & 0,8011 \\
\hline $\mathbf{1 2}$ & 8,0333 & 1,4019 & 0,1329 & 7,9333 & 1,2631 & 0,1184 & 0,5728 \\
\hline $\mathbf{1 1}$ & 6,8666 & 1,3349 & 0,1253 & 7,0000 & 1,2382 & 0,1131 & 0,4270 \\
\hline $\mathbf{2 1}$ & 6,9666 & 1,3034 & 0,1220 & 6,9333 & 1,2092 & 0,1107 & 0,8410 \\
\hline $\mathbf{2 2}$ & 8,0000 & 1,4375 & 0,1356 & 7,9000 & 1,2476 & 0,1156 & 0,5734 \\
\hline $\mathbf{2 3}$ & 11,0071 & 1,5345 & 0,1474 & 11,0000 & 1,6329 & 0,1548 & 0,9738 \\
\hline $\mathbf{2 4}$ & $\mathbf{9 , 6 3 5 7}$ & $\mathbf{1 , 7 0 6 6}$ & $\mathbf{0 , 1 6 1 5}$ & $\mathbf{1 0 , 1 3 3 3}$ & $\mathbf{1 , 5 6 4 8}$ & $\mathbf{0 , 1 4 6 4}$ & $\mathbf{0 , 0 2 2 9}$ \\
\hline $\mathbf{2 5}$ & $\mathbf{1 0 , 5 0 2 3}$ & $\mathbf{1 , 6 1 0 2}$ & $\mathbf{0 , 1 5 6 0}$ & $\mathbf{1 0 , 9 6 6 6}$ & $\mathbf{1 , 5 1 6 2}$ & $\mathbf{0 , 1 4 6 8}$ & $\mathbf{0 , 0 3 1 0}$ \\
\hline $\mathbf{2 6}$ & 6,2333 & 1,2565 & 0,1129 & 6,3000 & 1,1874 & 0,1066 & 0,6643 \\
\hline $\mathbf{2 7}$ & 11,9057 & 1,5286 & 0,1527 & 11,5666 & 1,4761 & 0,1437 & 0,1058 \\
\hline $\mathbf{3 7}$ & 11,5476 & 1,4409 & 0,1412 & 11,2000 & 1,4696 & 0,1430 & 0,0855 \\
\hline $\mathbf{3 6}$ & 6,2000 & 1,1944 & 0,1046 & 6,2000 & 1,2220 & 0,1131 & 1,0000 \\
\hline $\mathbf{3 5}$ & 11,0357 & 1,4280 & 0,1391 & 10,7666 & 1,5638 & 0,1489 & 0,1866 \\
\hline $\mathbf{3 4}$ & 9,9690 & 1,5201 & 0,1458 & 10,2000 & 1,4236 & 0,1347 & 0,2433 \\
\hline $\mathbf{3 3}$ & 9,9357 & 1,7149 & 0,1642 & 9,9000 & 1,4685 & 0,1431 & 0,8724 \\
\hline $\mathbf{3 2}$ & 7,1000 & 1,3988 & 0,1308 & 7,1333 & 1,2036 & 0,1096 & 0,8459 \\
\hline $\mathbf{3 1}$ & 6,2000 & 1,1372 & 0,0942 & 6,3000 & 1,1874 & 0,1044 & 0,4762 \\
\hline $\mathbf{4 1}$ & 6,0333 & 1,1967 & 0,1081 & 6,2333 & 1,1742 & 0,1000 & 0,1754 \\
\hline $\mathbf{4 2}$ & 7,0666 & 1,3646 & 0,1307 & 7,1333 & 1,2310 & 0,1124 & 0,6966 \\
\hline $\mathbf{4 3}$ & 9,7666 & 1,4533 & 0,1415 & 10,0333 & 1,4715 & 0,1434 & 0,1851 \\
\hline $\mathbf{4 4}$ & 9,8357 & 1,6787 & 0,1591 & 10,1000 & 1,4224 & 0,1363 & 0,2067 \\
\hline $\mathbf{4 5}$ & 10,8333 & 1,4624 & 0,1423 & 10,8000 & 1,7009 & 0,1623 & 0,8784 \\
\hline $\mathbf{4 6}$ & 6,2666 & 1,1527 & 0,0990 & 6,2333 & 1,2023 & 0,1095 & 0,8228 \\
\hline $\mathbf{4 7}$ & 11,5190 & 1,6189 & 0,1573 & 11,1333 & 1,5434 & 0,1503 & 0,0769
\end{tabular}


TABELA 11 - Idade média de erupção, desvio padrão e erro padrão de cada dente permanente, nos gêneros masculino e feminino, no grupo Vertical e o nível de significância estatística quando aplicado o teste $t$ independente entre os gêneros.

\begin{tabular}{c|c|c|c|c|c|c|c}
\hline \multirow{2}{*}{ DENTE } & \multicolumn{3}{|c|}{ MASCULINO } & \multicolumn{3}{c|}{ FEMININO } & \multirow{2}{*}{$\mathbf{p}$} \\
\cline { 2 - 6 } & MÉDIA & D.P. & E. P. & MÉDIA & D. P. & E. P & 0,8378 \\
\hline $\mathbf{1 7}$ & 11,9265 & 1,4269 & 0,1987 & 11,8647 & 1,5367 & 0,2282 & 0,8374 \\
\hline $\mathbf{1 6}$ & 6,0625 & 1,1973 & 0,1505 & 6,4285 & 1,1157 & 0,1372 & 0,0740 \\
\hline $\mathbf{1 5}$ & 10,6879 & 1,3964 & 0,1830 & 10,5757 & 1,7256 & 0,2466 & 0,7156 \\
\hline $\mathbf{1 4}$ & 10,1409 & 1,3265 & 0,1678 & 10,1085 & 1,6216 & 0,2316 & 0,9108 \\
\hline $\mathbf{1 3}$ & $\mathbf{1 1 , 3 6 7 4}$ & $\mathbf{1 , 6 1 4 8}$ & $\mathbf{0 , 2 1 3 5}$ & $\mathbf{1 0 , 7 2 6 1}$ & $\mathbf{1 , 2 7 5 6}$ & $\mathbf{0 , 1 7 9 7}$ & $\mathbf{0 , 0 2 3 2}$ \\
\hline $\mathbf{1 2}$ & 8,0504 & 1,3242 & 0,1792 & 8,0256 & 1,5104 & 0,2123 & 0,9284 \\
\hline $\mathbf{1 1}$ & 6,9889 & 1,1678 & 0,1387 & 6,7074 & 1,4688 & 0,2060 & 0,2594 \\
\hline $\mathbf{2 1}$ & 6,9889 & 1,1678 & 0,1387 & 6,9271 & 1,4244 & 0,2022 & 0,8035 \\
\hline $\mathbf{2 2}$ & 7,9663 & 1,3374 & 0,1699 & 8,0112 & 1,5560 & 0,2188 & 0,8707 \\
\hline $\mathbf{2 3}$ & 10,8582 & 1,6343 & 0,2130 & 11,1785 & 1,3901 & 0,2053 & 0,2816 \\
\hline $\mathbf{2 4}$ & $\mathbf{9 , 3 0 2 0}$ & $\mathbf{1 , 8 3 3 3}$ & $\mathbf{0 , 2 3 5 8}$ & $\mathbf{1 0 , 1 1 2 4}$ & $\mathbf{1 , 5 9 6 1}$ & $\mathbf{0 , 2 3 6 4}$ & $\mathbf{0 , 0 1 6 7}$ \\
\hline $\mathbf{2 5}$ & $\mathbf{1 0 , 1 3 9 4}$ & $\mathbf{1 , 6 2 9 3}$ & $\mathbf{0 , 2 1 5 7}$ & $\mathbf{1 0 , 9 5 3 2}$ & $\mathbf{1 , 4 8 6 3}$ & $\mathbf{0 , 2 2 0 6}$ & $\mathbf{0 , 0 0 9 4}$ \\
\hline $\mathbf{2 6}$ & 6,1339 & 1,3329 & 0,1666 & 6,3571 & 1,1715 & 0,1547 & 0,3245 \\
\hline $\mathbf{2 7}$ & 11,9335 & 1,4633 & 0,2023 & 11,8841 & 1,6024 & 0,2382 & 0,8756 \\
\hline $\mathbf{3 7}$ & 11,5476 & 1,4176 & 0,1943 & 11,5540 & 1,4662 & 0,2122 & 0,9806 \\
\hline $\mathbf{3 6}$ & $\mathbf{6 , 0 0 0 0}$ & $\mathbf{1 , 1 7 2 6}$ & $\mathbf{0 , 1 4 2 5}$ & $\mathbf{6 , 4 3 4 0}$ & $\mathbf{1 , 1 8 3 0}$ & $\mathbf{0 , 1 5 3 5}$ & $\mathbf{0 , 0 3 9 7}$ \\
\hline $\mathbf{3 5}$ & 11,1829 & 1,5587 & 0,2026 & 10,8809 & 1,2383 & 0,1820 & 0,2693 \\
\hline $\mathbf{3 4}$ & 10,0409 & 1,7254 & 0,2252 & 9,8653 & 1,2714 & 0,1917 & 0,5545 \\
\hline $\mathbf{3 3}$ & 10,1986 & 1,8729 & 0,2436 & 9,5746 & 1,4537 & 0,2138 & 0,0562 \\
\hline $\mathbf{3 2}$ & 7,1743 & 1,4220 & 0,1844 & 6,9931 & 1,3470 & 0,1839 & 0,4870 \\
\hline $\mathbf{3 1}$ & 6,1250 & 1,1110 & 0,1185 & 6,2857 & 1,1605 & 0,1508 & 0,4032 \\
\hline $\mathbf{4 1}$ & 5,8750 & 1,1659 & 0,1406 & 6,2142 & 1,2058 & 0,1645 & 0,1185 \\
\hline $\mathbf{4 2}$ & 7,0530 & 1,3483 & 0,1800 & 7,0700 & 1,3735 & 0,1943 & 0,9489 \\
\hline $\mathbf{4 3}$ & 9,9681 & 1,4837 & 0,1952 & 9,5657 & 1,3053 & 0,1929 & 0,0802 \\
\hline $\mathbf{4 4}$ & 9,7183 & 1,8118 & 0,2349 & 9,9313 & 1,5093 & 0,2189 & 0,5069 \\
\hline $\mathbf{4 5}$ & 10,9897 & 1,4151 & 0,1839 & 10,6382 & 1,5046 & 0,2293 & 0,2340 \\
\hline $\mathbf{4 6}$ & $\mathbf{6 , 0 6 2 5}$ & $\mathbf{1 , 1 4 3 9}$ & $\mathbf{0 , 1 3 2 0}$ & $\mathbf{6 , 5 0 0 0}$ & $\mathbf{1 , 1 1 8 0}$ & $\mathbf{0 , 1 3 8 6}$ & $\mathbf{0 , 0 2 3 3}$ \\
\hline $\mathbf{4 7}$ & 11,4369 & 1,6092 & 0,2145 & 11,6135 & 1,6100 & 0,2354 & 0,5788 \\
& & & & & & & \\
\hline
\end{tabular}


TABELA 12 - Idade média de erupção, desvio padrão e erro padrão de cada dente permanente, nos gêneros masculino e feminino, no grupo Horizontal e o nível de significância estatística quando aplicado o teste $t$ independente entre os gêneros.

\begin{tabular}{|c|c|c|c|c|c|c|c|}
\hline \multirow[t]{2}{*}{ DENTE } & \multicolumn{3}{|c|}{ MASCULINO } & \multicolumn{3}{|c|}{ FEMININO } & \\
\hline & MÉDIA & D.P. & E. P. & MÉDIA & D. P. & E.P & \\
\hline 17 & 11,9858 & 1,5429 & 0,2226 & 11,3673 & 1,5235 & 0,2009 & 0,0411 \\
\hline 16 & 6,3666 & 1,2242 & 0,1578 & 6,2238 & 1,2001 & 0,1609 & 0,5248 \\
\hline 15 & 10,6824 & 1,3940 & 0,1904 & 10,7862 & 1,8277 & 0,2368 & 0,7321 \\
\hline 14 & 10,1333 & 1,1756 & 0,1490 & 9,8046 & 1,6023 & 0,2144 & 0,2096 \\
\hline 13 & 11,4282 & 1,4064 & 0,2115 & 10,8529 & 1,6958 & 0,2218 & 0,0623 \\
\hline 12 & 09 & 1,1580 & 0,1456 & 7,7785 & 1,3473 & 0,1863 &, 2030 \\
\hline 11 & & 1,1895 & 0,1521 & 6,7809 & 1,2534 & 0,1685 & 0,0614 \\
\hline 21 & 7,1416 & 1,1711 & 0,1458 & 6,7047 & 1,2143 & 0,1645 & 0,0482 \\
\hline 22 & 8.0095 & 1,1296 & 0,1329 & 7,7785 & 1,3473 & 0,1863 & 0,3131 \\
\hline 23 & 11,4448 & 1,5642 & 0,2329 & 10,6052 & 1,6276 & 0,2080 & \\
\hline 24 & 10,3602 & 1,4552 & 0,2035 & 9,9773 & 1,6179 & 0,2081 & 0,1903 \\
\hline 25 & 11,0474 & 1,3705 & 0,1939 & 10,8640 & 1,6333 & 0,2205 & 0,5332 \\
\hline 26 & 6,4 & 1,2294 & 0,1570 & & 1,1221 & 0,1318 & \\
\hline 27 & 11,9653 & 1,4142 & 0,2150 & 11,2529 & 1,4719 & 0,1927 & 0,0151 \\
\hline 37 & 11,7320 & 1,4478 & 0,2136 & 10,7607 & 1,3796 & 0,1876 & 0,0009 \\
\hline 36 & 6,4958 & 1,1761 & 0,1443 & 5,8761 & 1,1807 & 0,1529 & 0,0037 \\
\hline 35 & 10,8102 & 1,1434 & 0,1410 & 10,6496 & 1,8300 & 0,2352 & 0,5280 \\
\hline 34 & 10,4205 & 1,3483 & 0,1903 & 9,9926 & 1,4587 & 0,1914 & 0,1151 \\
\hline 33 & 10,2871 & 1,4302 & 0,2048 & 9,5458 & 1,4222 & 0,1984 & 0,0105 \\
\hline 32 & & 1,1 & 0,1472 & & 1,1814 & 0,1447 & 0,0100 \\
\hline 31 & 33 & 1,1604 & 0,1416 & 6,2857 & 1,2127 & 0,1568 & 0,9131 \\
\hline 41 & 6,2458 & 1,1483 & 0,1369 & 6,2142 & 1,1979 & 0,1477 & 0,8772 \\
\hline 42 & 7,4089 & 1,2286 & 0,1617 & 6,8476 & 1,1814 & 0,1547 & 0,0132 \\
\hline 43 & & 1,34 & 0,1920 & & 1,4253 & 0,1959 & \\
\hline 44 & 10,4205 & 1,3483 & 0,1903 & 9,7884 & 1,4244 & 0,1891 & 0,0202 \\
\hline 45 & 11,0512 & 1,3696 & 0,1952 & 10,5283 & 1,9069 & 0,2450 & 0,0978 \\
\hline 46 & & 1,1180 & 0,1290 & 5,9476 & 1,2158 & 0,1640 & 0,0091 \\
\hline 47 & 11,5782 & 1,4642 & 0,2159 & 10,7418 & 1,5447 & 0,2083 & 0,0062 \\
\hline
\end{tabular}


TABELA 13 - Idade média de erupção, desvio padrão e erro padrão de cada dente permanente dos jovens do gênero masculino nos grupos Vertical e Horizontal e o nível de significância estatística quando aplicado o teste $t$ independente entre os grupos.

\begin{tabular}{c|c|c|c|c|c|c|c}
\hline \multirow{2}{*}{ DENTE } & \multicolumn{3}{|c|}{ VERTICAL } & \multicolumn{3}{c|}{ HORIZONTAL } & \multirow{2}{*}{$\mathbf{p}$} \\
\cline { 2 - 7 } & MÉDIA & D.P. & E. P. & MÉDIA & D. P. & E. P & \\
\hline $\mathbf{1 7}$ & 11,9265 & 1,4269 & 0,1987 & 11,9858 & 1,5429 & 0,2226 & 0,8429 \\
\hline $\mathbf{1 6}$ & 6,0625 & 1,1973 & 0,1505 & 6,3666 & 1,2242 & 0,1578 & 0,1657 \\
\hline $\mathbf{1 5}$ & 10,6879 & 1,3964 & 0,1830 & 10,6824 & 1,3940 & 0,1904 & 0,9834 \\
\hline $\mathbf{1 4}$ & 10,1409 & 1,3265 & 0,1678 & 10,1333 & 1,1756 & 0,1490 & 0,9730 \\
\hline $\mathbf{1 3}$ & 11,3674 & 1,6148 & 0,2135 & 11,4282 & 1,4064 & 0,2115 & 0,8401 \\
\hline $\mathbf{1 2}$ & 8,0504 & 1,3242 & 0,1792 & 8,0809 & 1,1580 & 0,1456 & 0,8951 \\
\hline $\mathbf{1 1}$ & 6,9889 & 1,1678 & 0,1387 & 7,2083 & 1,1895 & 0,1521 & 0,2885 \\
\hline $\mathbf{2 1}$ & 6,9889 & 1,1678 & 0,1387 & 7,1416 & 1,1711 & 0,1458 & 0,4493 \\
\hline $\mathbf{2 2}$ & 7,9663 & 1,3374 & 0,1699 & 8,0095 & 1,1296 & 0,1329 & 0,8416 \\
\hline $\mathbf{2 3}$ & 10,8582 & 1,6343 & 0,2130 & 11,4448 & 1,5642 & 0,2329 & 0,0660 \\
\hline $\mathbf{2 4}$ & $\mathbf{9 , 3 0 2 0}$ & $\mathbf{1 , 8 3 3 3}$ & $\mathbf{0 , 2 3 5 8}$ & $\mathbf{1 0 , 3 6 0 2}$ & $\mathbf{1 , 4 5 5 2}$ & $\mathbf{0 , 2 0 3 5}$ & $\mathbf{0 , 0 0 1 0}$ \\
\hline $\mathbf{2 5}$ & $\mathbf{1 0 , 1 3 9 4}$ & $\mathbf{1 , 6 2 9 3}$ & $\mathbf{0 , 2 1 5 7}$ & $\mathbf{1 1 , 0 4 7 4}$ & $\mathbf{1 , 3 7 0 5}$ & $\mathbf{0 , 1 9 3 9}$ & $\mathbf{0 , 0 0 2 3}$ \\
\hline $\mathbf{2 6}$ & 6,1339 & 1,3329 & 0,1666 & 6,4291 & 1,2294 & 0,1570 & 0,1996 \\
\hline $\mathbf{2 7}$ & 11,9335 & 1,4633 & 0,2023 & 11,9653 & 1,4142 & 0,2150 & 0,9145 \\
\hline $\mathbf{3 7}$ & 11,5476 & 1,4176 & 0,1943 & 11,7320 & 1,4478 & 0,2136 & 0,5246 \\
\hline $\mathbf{3 6}$ & $\mathbf{6 , 0 0 0 0}$ & $\mathbf{1 , 1 7 2 6}$ & $\mathbf{0 , 1 4 2 5}$ & $\mathbf{6 , 4 9 5 8}$ & $\mathbf{1 , 1 7 6 1}$ & $\mathbf{0 , 1 4 4 3}$ & $\mathbf{0 , 0 1 5 8}$ \\
\hline $\mathbf{3 5}$ & 11,1829 & 1,5587 & 0,2026 & 10,8102 & 1,1434 & 0,1410 & 0,1337 \\
\hline $\mathbf{3 4}$ & 10,0409 & 1,7254 & 0,2252 & 10,4205 & 1,3483 & 0,1903 & 0,2007 \\
\hline $\mathbf{3 3}$ & 10,1986 & 1,8729 & 0,2436 & 10,2871 & 1,4302 & 0,2048 & 0,7815 \\
\hline $\mathbf{3 2}$ & 7,1743 & 1,4220 & 0,1844 & 7,4041 & 1,1686 & 0,1472 & 0,3320 \\
\hline $\mathbf{3 1}$ & 6,1250 & 1,1110 & 0,1185 & 6,3083 & 1,1604 & 0,1416 & 0,3224 \\
\hline $\mathbf{4 1}$ & 5,8750 & 1,1659 & 0,1406 & 6,2458 & 1,1483 & 0,1369 & 0,0609 \\
\hline $\mathbf{4 2}$ & 7,0530 & 1,3483 & 0,1800 & 7,4089 & 1,2286 & 0,1617 & 0,1442 \\
\hline $\mathbf{4 3}$ & $\mathbf{9 , 9 6 8 1}$ & $\mathbf{1 , 4 8 3 7}$ & $\mathbf{0 , 1 9 5 2}$ & $\mathbf{1 0 , 5 5 3 8}$ & $\mathbf{1 , 3 4 9 6}$ & $\mathbf{0 , 1 9 2 0}$ & $\mathbf{0 , 0 3 4 7}$ \\
\hline $\mathbf{4 4}$ & $\mathbf{9 , 7 1 8 3}$ & $\mathbf{1 , 8 1 1 8}$ & $\mathbf{0 , 2 3 4 9}$ & $\mathbf{1 0 , 4 2 0 5}$ & $\mathbf{1 , 3 4 8 3}$ & $\mathbf{0 , 1 9 0 3}$ & $\mathbf{0 , 0 2 2 1}$ \\
\hline $\mathbf{4 5}$ & 10,9897 & 1,4151 & 0,1839 & 11,0512 & 1,3696 & 0,1952 & 0,8191 \\
\hline $\mathbf{4 6}$ & $\mathbf{6 , 0 6 2 5}$ & $\mathbf{1 , 1 4 3 9}$ & $\mathbf{0 , 1 3 2 0}$ & $\mathbf{6 , 5 0 0 0}$ & $\mathbf{1 , 1 1 8 0}$ & $\mathbf{0 , 1 2 9 0}$ & $\mathbf{0 , 0 1 9 1}$ \\
\hline $\mathbf{4 7}$ & 11,4369 & 1,6092 & 0,2145 & 11,5782 & 1,4642 & 0,2159 & 0,6435 \\
\hline & & & & & & & \\
\hline
\end{tabular}


TABELA 14 - Idade média de erupção, desvio padrão e erro padrão de cada dente permanente das jovens do gênero feminino nos grupos Vertical e Horizontal e o nível de significância estatística quando aplicado o teste $t$ independente entre os grupos.

\begin{tabular}{|c|c|c|c|c|c|c|c|}
\hline \multirow[t]{2}{*}{ DENTE } & \multicolumn{3}{|c|}{ VERTICAL } & \multicolumn{3}{|c|}{ HORIZONTAL } & \\
\hline & MÉDIA & D.P. & E.P. & MÉDIA & D. P. & E. P & \\
\hline 17 & 11,8647 & 1,5367 & 0,2282 & 11,3673 & 1,5235 & 0,2009 & 0,1050 \\
\hline 16 & 6,4285 & 1,1157 & 0,1372 & 6,2238 & 1,2001 & 0,1609 & 0,3350 \\
\hline 15 & 10,5757 & 1,7256 & 0,2466 & 10,7862 & 1,8277 & 0,2368 & 0,5394 \\
\hline 14 & 10,1085 & 1,6216 & 0,2316 & 9,8046 & 1,6023 & 0,2144 & 0,3379 \\
\hline 13 & 10,7261 & 1,2756 & 0,1797 & 10,8529 & 1,6958 & 0,2218 & 0,6578 \\
\hline 12 & 8,0256 & 1,5104 & 0,2123 & 7,7785 & 1,3473 & 0,1863 & 0,3838 \\
\hline 11 & & 1,4688 & 0,2060 & 6,7809 & 2534 & 0,1685 & 0,7830 \\
\hline 21 & 6,9271 & 1,4244 & 0,2022 & 6,7047 & 1,2143 & 0,1645 & 0,3955 \\
\hline 22 & 8,0112 & 1,5560 & 0,2188 & 7,7785 & 1,3473 & 0,1863 & 0,4200 \\
\hline 23 & 11,1785 & 1,3901 & 0,2053 & 10,6052 & 276 & 0,2080 & 0,0525 \\
\hline 24 & 10,1124 & 1,5961 & 0,2364 & 9,9773 & 179 & 0,2081 & 0,6688 \\
\hline 25 & 10,9532 & 1,4863 & 0,2206 & 10,8640 & 1,6333 & 0,2205 & 0,7755 \\
\hline 26 & & 1,1715 & 0,1547 & 6,1476 & 1,1221 & 0,1318 & 0,3046 \\
\hline 27 & 11,8841 & 1,6024 & 0,2382 & 11,2529 & 1,4719 & 0,1927 & 0,0420 \\
\hline 37 & 11,5540 & 1,4662 & 0,2122 & 10,7607 & 1,3796 & 0,1876 & 0,0061 \\
\hline 36 & 6,4340 & 1,1830 & 0,1535 & 5,8761 & 1,1807 & 0,1529 & 0,0113 \\
\hline 35 & 10 , & 1,23 & 0,1820 & 10,6496 & & 0,2352 & 0,4385 \\
\hline 34 & 9,8653 & 1,2714 & 0,1917 & 9,9926 & 1,4587 & 0,1914 & 0,6394 \\
\hline 33 & 9,5746 & 1,4537 & 0,2138 & 9,5458 & 1,4222 & 0,1984 & 0,9216 \\
\hline 32 & 6,9931 & 1,3470 & 0,1839 & 6,8476 & 1,1814 & 0,1447 & 0,5353 \\
\hline 31 & & 1,1605 & 0,1508 & 6,2857 & 27 & 0,1568 & 1,0000 \\
\hline 41 & & 1,20 & 0,1645 & 6,2142 & 79 & 0,1477 & 1,0000 \\
\hline 42 & 7,0700 & 1,3735 & 0,1943 & 6,8476 & 1,1814 & 0,1547 & 0,3726 \\
\hline 43 & 9,5657 & 1,3053 & 0,1929 & 9,5416 & 1,4253 & 0,1959 & 0,9303 \\
\hline 44 & & 1,5093 & 0,2189 & 9,7884 & 1,4244 & 0,1891 & 0,6224 \\
\hline 45 & & 1,5046 & 0,2293 & 10,5283 & 1,9069 & 0,2450 & 0,7440 \\
\hline 46 & 6,5000 & 1,1180 & 0,1386 & 5,9476 & 1,2158 & 0,1640 & 0,0113 \\
\hline 47 & 11,6135 & 1,6100 & 0,2354 & 10,7418 & 1,5447 & 0,2083 & 0,0066 \\
\hline
\end{tabular}


TABELA 15 - Nível de significância estatística (p) quando aplicado o teste $\mathrm{t}$ independente entre as idades médias de erupção dos dentes permanentes dos lados direito e esquerdo no grupo Vertical.

\begin{tabular}{c|c|c|c|c|c|c}
\hline DENTE & MÉDIA & D. P. & DENTE & MÉDIA & D. P. & p \\
\hline $\mathbf{1 7}$ & 11,9014 & 1,4781 & $\mathbf{2 7}$ & 11,9057 & 1,5286 & 0,9849 \\
\hline $\mathbf{1 6}$ & 6,2333 & 1,1742 & $\mathbf{2 6}$ & 6,2333 & 1,2565 & 1,0000 \\
\hline $\mathbf{1 5}$ & 10,6357 & 1,5624 & $\mathbf{2 5}$ & 10,5023 & 1,6102 & 0,5369 \\
\hline $\mathbf{1 4}$ & $\mathbf{1 0 , 1 3 5 7}$ & $\mathbf{1 , 4 8 1 0}$ & $\mathbf{2 4}$ & $\mathbf{9 , 6 3 5 7}$ & $\mathbf{1 , 7 0 6 6}$ & $\mathbf{0 , 0 2 0 0}$ \\
\hline $\mathbf{1 3}$ & 11,0804 & 1,4994 & $\mathbf{2 3}$ & 11,0071 & 1,5345 & 0,7231 \\
\hline $\mathbf{1 2}$ & 8,0333 & 1,4019 & $\mathbf{2 2}$ & 8,0000 & 1,4375 & 0,8614 \\
\hline $\mathbf{1 1}$ & 6,8666 & 1,3349 & $\mathbf{2 1}$ & 6,9666 & 1,3034 & 0,5675 \\
\hline $\mathbf{4 1}$ & 6,0333 & 1,1967 & $\mathbf{3 1}$ & 6,2000 & 1,1372 & 0,2445 \\
\hline $\mathbf{4 2}$ & 7,0666 & 1,3646 & $\mathbf{3 2}$ & 7,1000 & 1,3988 & 0,8534 \\
\hline $\mathbf{4 3}$ & 9,7666 & 1,4533 & $\mathbf{3 3}$ & 9,9357 & 1,7149 & 0,4354 \\
\hline $\mathbf{4 4}$ & 9,8357 & 1,6787 & $\mathbf{3 4}$ & 9,9690 & 1,5201 & 0,5341 \\
\hline $\mathbf{4 5}$ & 10,8333 & 1,4624 & $\mathbf{3 5}$ & 11,0357 & 1,4280 & 0,3105 \\
\hline $\mathbf{4 6}$ & 6,2666 & 1,1527 & $\mathbf{3 6}$ & 6,2000 & 1,1944 & 0,6461 \\
\hline $\mathbf{4 7}$ & 11,5190 & 1,6189 & $\mathbf{3 7}$ & 11,5476 & 1,4409 & 0,8946 \\
\hline
\end{tabular}

TABELA 16 - Nível de significância estatística (p) quando aplicado o teste $\mathrm{t}$ independente entre as idades médias de erupção dos dentes permanentes dos lados direito e esquerdo no grupo Horizontal.

\begin{tabular}{c|c|c|c|c|c|c}
\hline DENTE & MÉDIA & D. P. & DENTE & MÉDIA & D. P. & p \\
\hline $\mathbf{1 7}$ & 11,6333 & 1,5595 & $\mathbf{2 7}$ & 11,5666 & 1,4761 & 0,7476 \\
\hline $\mathbf{1 6}$ & 6,3000 & 1,2151 & $\mathbf{2 6}$ & 6,3000 & 1,1874 & 1,0000 \\
\hline $\mathbf{1 5}$ & 10,7666 & 1,6468 & $\mathbf{2 5}$ & 10,9666 & 1,5162 & 0,3486 \\
\hline $\mathbf{1 4}$ & 10,4333 & 1,5205 & $\mathbf{2 4}$ & 10,1333 & 1,5648 & 0,1287 \\
\hline $\mathbf{1 3}$ & 11,1333 & 1,5860 & $\mathbf{2 3}$ & 11,0000 & 1,6329 & 0,5407 \\
\hline $\mathbf{1 2}$ & 7,9333 & 1,2631 & $\mathbf{2 2}$ & 7,9000 & 1,2476 & 0,8414 \\
\hline $\mathbf{1 1}$ & 7,0000 & 1,2382 & $\mathbf{2 1}$ & 6,9333 & 1,2092 & 0,6713 \\
\hline $\mathbf{4 1}$ & 6,2333 & 1,1742 & $\mathbf{3 1}$ & 6,3000 & 1,1874 & 0,6428 \\
\hline $\mathbf{4 2}$ & 7,1333 & 1,2310 & $\mathbf{3 2}$ & 7,1333 & 1,2036 & 1,0000 \\
\hline $\mathbf{4 3}$ & 10,0333 & 1,4715 & $\mathbf{3 3}$ & 9,9000 & 1,4685 & 0,5115 \\
\hline $\mathbf{4 4}$ & 10,1000 & 1,4224 & $\mathbf{3 4}$ & 10,2000 & 1,4236 & 0,6010 \\
\hline $\mathbf{4 5}$ & 10,8000 & 1,7009 & $\mathbf{3 5}$ & 10,7666 & 1,5638 & 0,8770 \\
\hline $\mathbf{4 6}$ & 6,2333 & 1,2023 & $\mathbf{3 6}$ & 6,2000 & 1,2220 & 0,8337 \\
\hline $\mathbf{4 7}$ & 11,1333 & 1,5434 & $\mathbf{3 7}$ & 11,2000 & 1,4696 & 0,7468 \\
\hline
\end{tabular}


TABELA 17 - Nível de significância estatística (p) quando aplicado o teste t independente entre as idades médias de erupção dos dentes permanentes dos arcos superior e inferior no grupo Vertical.

\begin{tabular}{c|c|c|c|c|c|c}
\hline DENTE & MÉDIA & D. P. & DENTE & MÉDIA & D. P. & p \\
\hline $\mathbf{1 7}$ & 11,9014 & 1,4781 & $\mathbf{4 7}$ & 11,5190 & 1,6189 & 0,0772 \\
\hline $\mathbf{1 6}$ & 6,2333 & 1,1742 & $\mathbf{4 6}$ & 6,2666 & 1,1527 & 0,8175 \\
\hline $\mathbf{1 5}$ & 10,6357 & 1,5624 & $\mathbf{4 5}$ & 10,8333 & 1,4624 & 0,3354 \\
\hline $\mathbf{1 4}$ & 10,1357 & 1,4810 & $\mathbf{4 4}$ & 9,8357 & 1,6787 & 0,1582 \\
\hline $\mathbf{1 3}$ & $\mathbf{1 1 , 0 8 0 4}$ & $\mathbf{1 , 4 9 9 4}$ & $\mathbf{4 3}$ & $\mathbf{9 , 7 6 6 6}$ & $\mathbf{1 , 4 5 3 3}$ & $\mathbf{0 , 0 0 0 0}$ \\
\hline $\mathbf{1 2}$ & $\mathbf{8 , 0 3 3 3}$ & $\mathbf{1 , 4 0 1 9}$ & $\mathbf{4 2}$ & $\mathbf{7 , 0 6 6 6}$ & $\mathbf{1 , 3 6 4 6}$ & $\mathbf{0 , 0 0 0 0}$ \\
\hline $\mathbf{1 1}$ & $\mathbf{6 , 8 6 6 6}$ & $\mathbf{1 , 3 3 4 9}$ & $\mathbf{4 1}$ & $\mathbf{6 , 0 3 3 3}$ & $\mathbf{1 , 1 9 6 7}$ & $\mathbf{0 , 0 0 0 0}$ \\
\hline $\mathbf{2 1}$ & $\mathbf{6 , 9 6 6 6}$ & $\mathbf{1 , 3 0 3 4}$ & $\mathbf{3 1}$ & $\mathbf{6 , 2 0 0 0}$ & $\mathbf{1 , 1 3 7 2}$ & $\mathbf{0 , 0 0 0 0}$ \\
\hline $\mathbf{2 2}$ & $\mathbf{8 , 0 0 0 0}$ & $\mathbf{1 , 4 3 7 5}$ & $\mathbf{3 2}$ & $\mathbf{7 , 1 0 0 0}$ & $\mathbf{1 , 3 9 8 8}$ & $\mathbf{0 , 0 0 0 0}$ \\
\hline $\mathbf{2 3}$ & $\mathbf{1 1 , 0 0 7 1}$ & $\mathbf{1 , 5 3 4 5}$ & $\mathbf{3 3}$ & $\mathbf{9 , 9 3 5 7}$ & $\mathbf{1 , 7 1 4 9}$ & $\mathbf{0 , 0 0 0 0}$ \\
\hline $\mathbf{2 4}$ & 9,6357 & 1,7066 & $\mathbf{3 4}$ & 9,9690 & 1,5201 & 0,1246 \\
\hline $\mathbf{2 5}$ & $\mathbf{1 0 , 5 0 2 3}$ & $\mathbf{1 , 6 1 0 2}$ & $\mathbf{3 5}$ & $\mathbf{1 1 , 0 3 5 7}$ & $\mathbf{1 , 4 2 8 0}$ & $\mathbf{0 , 0 1 1 5}$ \\
\hline $\mathbf{2 6}$ & $\mathbf{6 , 2 3 3 3}$ & 1,2565 & $\mathbf{3 6}$ & 6,2000 & 1,1944 & 0,8292 \\
\hline $\mathbf{2 7}$ & 11,9057 & 1,5286 & $\mathbf{3 7}$ & 11,5476 & 1,4409 & 0,0857
\end{tabular}

TABELA 18 - Nível de significância estatística (p) quando aplicado o teste t independente entre as idades médias de erupção dos dentes permanentes dos arcos superior e inferior no grupo Horizontal.

\begin{tabular}{c|c|c|c|c|c|c}
\hline DENTE & MÉDIA & $\mathbf{D . P .}$ & DENTE & MÉDIA & $\mathbf{D . ~ P . ~}$ & $\mathbf{p}$ \\
\hline $\mathbf{1 7}$ & $\mathbf{1 1 , 6 3 3 3}$ & $\mathbf{1 , 5 5 9 5}$ & $\mathbf{4 7}$ & $\mathbf{1 1 , 1 3 3 3}$ & $\mathbf{1 , 5 4 3 4}$ & $\mathbf{0 , 0 1 9 7}$ \\
\hline $\mathbf{1 6}$ & 6,3000 & 1,2151 & $\mathbf{4 6}$ & 6,2333 & 1,2023 & 0,6671 \\
\hline $\mathbf{1 5}$ & 10,7666 & 1,6468 & $\mathbf{4 5}$ & 10,8000 & 1,7009 & 0,8796 \\
\hline $\mathbf{1 4}$ & 10,4333 & 1,5205 & $\mathbf{4 4}$ & 10,1000 & 1,4424 & 0,0802 \\
\hline $\mathbf{1 3}$ & $\mathbf{1 1 , 1 3 3 3}$ & $\mathbf{1 , 5 8 6 0}$ & $\mathbf{4 3}$ & $\mathbf{1 0 , 0 3 3 3}$ & $\mathbf{1 , 4 7 1 5}$ & $\mathbf{0 , 0 0 0 0}$ \\
\hline $\mathbf{1 2}$ & $\mathbf{7 , 9 3 3 3}$ & $\mathbf{1 , 2 6 3 1}$ & $\mathbf{4 2}$ & $\mathbf{7 , 1 3 3 3}$ & $\mathbf{1 , 2 3 1 0}$ & $\mathbf{0 , 0 0 0 0}$ \\
\hline $\mathbf{1 1}$ & $\mathbf{7 , 0 0 0 0}$ & $\mathbf{1 , 2 3 8 2}$ & $\mathbf{4 1}$ & $\mathbf{6 , 2 3 3 3}$ & $\mathbf{1 , 1 7 4 2}$ & $\mathbf{0 , 0 0 0 0}$ \\
\hline $\mathbf{2 1}$ & $\mathbf{6 , 9 3 3 3}$ & $\mathbf{1 , 2 0 9 2}$ & $\mathbf{3 1}$ & $\mathbf{6 , 3 0 0 0}$ & $\mathbf{1 , 1 8 7 4}$ & $\mathbf{0 , 0 0 0 0}$ \\
\hline $\mathbf{2 2}$ & $\mathbf{7 , 9 0 0 0}$ & $\mathbf{1 , 2 4 7 6}$ & $\mathbf{3 2}$ & $\mathbf{7 , 1 3 3 3}$ & $\mathbf{1 , 2 0 3 6}$ & $\mathbf{0 , 0 0 0 0}$ \\
\hline $\mathbf{2 3}$ & $\mathbf{1 1 , 0 0 0 0}$ & $\mathbf{1 , 6 3 2 9}$ & $\mathbf{3 3}$ & $\mathbf{9 , 9 0 0 0}$ & $\mathbf{1 , 4 6 8 5}$ & $\mathbf{0 , 0 0 0 0}$ \\
\hline $\mathbf{2 4}$ & 10,1333 & 1,5648 & $\mathbf{3 4}$ & 10,2000 & 1,4236 & 0,7356 \\
\hline $\mathbf{2 5}$ & 10,9666 & 1,5162 & $\mathbf{3 5}$ & 10,7666 & 1,5638 & 0,3371 \\
\hline $\mathbf{2 6}$ & 6,3000 & 1,1874 & $\mathbf{3 6}$ & 6,2000 & 1,2220 & 0,5193 \\
\hline $\mathbf{2 7}$ & 11,5666 & 1,4761 & $\mathbf{3 7}$ & 11,2000 & 1,4696 & 0,0718 \\
\hline
\end{tabular}


6. Discussão 


\section{DISCUSSÃO}

Com o propósito de facilitar o entendimento e a interpretação dos dados obtidos neste trabalho, serão discutidos a seguir a amostra utilizada, a metodologia empregada e os resultados obtidos, além de serem realizadas algumas considerações clínicas relacionadas ao tema discorrido no presente estudo.

\subsection{A amostra utilizada}

\subsubsection{Telerradiografias em norma lateral}

Para a composição da amostra selecionourse inicialmente as telerradiografias em norma lateral de 111 dos 256 jovens da amostra longitudinal da Disciplina de Ortodontia da FOB - USP, todas obtidas aos oito anos de idade, de acordo com as normas técnicas preconizadas pela Disciplina de Radiologia da FOB - USP. Estas telerradiografias foram traçadas e a partir das mensurações das grandezas cefalométricas avaliadas (SN.GoGn, NS.Gn, FMA e AFAI) os jovens foram classificados de acordo com o tipo de padrão de crescimento facial.

Foram selecionados apenas jovens leucodermas, por meio da observação das fichas preenchidas pelos pais ou responsáveis desses jovens e pelas fotografias frontais dos mesmos, uma vez que a raça pode influenciar no desenvolvimento dos dentes permanentes ${ }^{12,59,65,69,112}$. Outro critério utilizado foi a presença de todos os dentes permanentes (observados nas radiografias panorâmicas), independentemente dos estágios de desenvolvimento em que eles se encontrassem, com exceção dos terceiros molares, pois, um dos propósitos deste estudo foi a comparação da idade média de erupção de todos os dentes permanentes (exceto os terceiros molares) entre os dois grupos considerados, bem como a seqüência de erupção dos mesmos. Foram excluídos da amostra os indivíduos que apresentaram dentes supranumerários, pois, estes dentes podem alterar tanto a cronologia como a seqüência de erupção dos dentes permanentes próximos 
a eles, principalmente na região ântero-superior ${ }^{119}$. Outros fatores que podem alterar o desenvolvimento dentário, como por exemplo, distúrbios endócrinos, níveis sócio-econômicos, história de traumatismos dentários, não foram considerados durante a seleção da amostra, pois a mesma foi coletada entre os anos de 1967 e 1987 e faz parte do arquivo de documentações da Disciplina de Ortodontia da FOB - USP, não havendo registros de tais informações.

\subsubsection{Radiografias panorâmicas}

Dos 111 jovens selecionados inicialmente e classificados de acordo com o tipo de padrão de crescimento facial, foram selecionados 60 jovens para a avaliação da maturação dos dentes permanentes, por meio de radiografias panorâmicas. Selecionourse os 30 jovens que apresentaram o maior predomínio de crescimento vertical, passando a constituir o Grupo Vertical, e os 30 que apresentaram o maior predomínio de crescimento horizontal, constituindo o Grupo Horizontal. Assim, foram selecionados os tipos faciais extremos, deixando a amostra mais característica e reduzindo a possibilidade de incluir nos grupos os jovens com características faciais híbridas, o que poderia reduzir as diferenças existentes entre os grupos estudados. Os dois grupos foram considerados estatisticamente diferentes em relação ao tipo de padrão de crescimento facial (Tabela 7). Os dois grupos apresentaram a mesma distribuição quanto ao gênero (15 jovens de gênero masculino e 15 do feminino em cada grupo), de forma que esta variável não apresentou nenhuma influência nos resultados obtidos. Em relação à idade cronológica média dos jovens, os dois grupos apresentaram-se bastante homogêneos (Grupo Vertical: 8,50 anos e o Grupo Horizontal: 8,48 anos).

A idade de 8 anos foi adotada para a avaliação da maturação dentária, pelo fato dos jovens apresentarem nesta idade os dentes permanentes em diversos estágios de desenvolvimento diferentes. Se fosse adotada uma idade mais avançada, por exemplo, 12 anos, os jovens provavelmente apresentariam todos os incisivos e os primeiros molares com o ápice radicular fechado 30 (estágio $\mathrm{H}$ do método de DEMIRJIAN; GOLDSTEIN; TANNER ${ }^{26}$ ), restando para a comparação entre os grupos apenas os estágios de desenvolvimento 
dos caninos, pré-molares e segundos molares. Se fosse adotada uma idade mais precoce, por exemplo, 5 anos, os jovens provavelmente apresentariam seus dentes permanentes em estágios de desenvolvimento mais precoces, principalmente os pré-molares, caninos e segundos molares; os incisivos e primeiros molares provavelmente se encontrariam em estágios de desenvolvimento intermediários. Logo, a idade de 8 anos mostrourse uma idade intermediária, onde se pôde observar os dentes permanentes em variadas fases de desenvolvimento dentário, abrangendo 7 dos 8 estágios de desenvolvimento do método de DEMIRJIAN; GOLDSTEIN; TANNER ${ }^{26}$, favorecendo assim, a comparação da maturação dentária entre os grupos estudados.

\subsubsection{Modelos de gesso}

Posteriormente, da amostra inicial de 111 jovens classificados de acordo com o padrão de crescimento facial, foram selecionados 533 pares de modelos de gesso de 97 jovens, na faixa etária dos 5 aos 13 anos, que também foram divididos em dois grupos (Grupo Vertical e Grupo Horizontal), de acordo com a classificação citada anteriormente (Tabela 1). Estes modelos de gesso foram analisados para se obter a idade média e a seqüência média de erupção dos dentes permanentes.

Foi estudada a faixa etária dos 5 aos 13 anos por consistir no período de erupção dos dentes permanentes, dos incisivos centrais aos segundos molares. Como foram analisados apenas os modelos de gesso desses jovens, não foram considerados os casos de anquilose dentoalveolar dos dentes antecessores, de tratamento endodôntico (pulpotomia / pulpectomia) dos dentes antecessores, de processos patológicos na região periapical dos dentes decíduos e de perda prematura dos dentes decíduos. Sabe-se que estes fatores podem exercer influência na cronologia e seqüência de erupção dos dentes permanentes $6,12,57,63,64,66,92,94,119$, mas pela impossibilidade de avaliálos apenas por meio dos modelos de gesso, não foram considerados. A perda prematura poderia até ser considerada, mas apenas em casos onde o dente decíduo tivesse sido extraído muito precocemente. O diagnóstico de perda 
prematura de dente decíduo seria baseado apenas na observação dos modelos de gesso, o que geraria dúvidas em alguns casos, não podendo assim afirmar categoricamente este diagnóstico, sem poder contar com uma anamnese e exame radiográfico que certamente auxiliariam no diagnóstico. Desta maneira, optourse por não considerá-la. Além disso, a probabilidade desses fatores serem encontrados nos diferentes grupos era semelhante.

Os dois grupos apresentaram distribuição semelhante quanto ao gênero e idade cronológica média dos jovens, nas idades estudadas, como pode ser observado nas tabelas dos apêndices (Tabelas A-4 a A-21).

\subsection{A metodologia empregada}

\subsubsection{Classificação do tipo de padrão de crescimento facial}

Para a classificação do tipo de padrão de crescimento facial dos 111 jovens selecionados por meio das telerradiografias em norma lateral, foram utilizadas as grandezas cefalométricas SN.GoGn, NS.Gn, FMA e AFAI. Para selecionar os 60 jovens que apresentassem os tipos faciais extremos, os valores dessas quatro grandezas cefalométricas consideradas foram somados. Os 30 jovens que apresentaram os maiores valores foram selecionados para constituir o Grupo Vertical e de maneira similar, os 30 jovens que apresentaram os menores valores da soma das quatro grandezas cefalométricas foram selecionados para constituir o Grupo Horizontal.

Existem outros métodos que podem ser utilizados para a classificação dos tipos faciais, como a proporção da altura facial ântero-inferior (AFAI) pela altura facial anterior total (AFAT), e a quantidade de trespasse vertical (positivo ou negativo), ambos utilizados por JANSON et al. ${ }^{50}$, entre outros. Optou-se por utilizar neste estudo as grandezas cefalométricas citadas anteriormente, por elas apresentarem-se amplamente utilizadas pelos ortodontistas e serem de simples localização e medição. Realizou-se a soma dessas variáveis cefalométricas, pois sabe-se que quanto maior o valor de cada uma delas, maior a tendência do predomínio do vetor de crescimento vertical, e quanto 
menor o valor das mesmas, maior a tendência do predomínio do vetor de crescimento horizontal. Assim, com apenas um valor numérico, ficaria mais simples realizar a classificação do tipo de padrão de crescimento facial. Além disto, se considerássemos uma determinada grandeza cefalométrica individualmente, poderia haver interferência de outros fatores (como por exemplo, a deflexão da base do crânio), mascarando o real predomínio de um determinado vetor de crescimento facial. Efetuando-se a soma das quatro variáveis cefalométricas estudadas, estamos considerando o predomínio geral do tipo de padrão de crescimento facial, diminuindo o efeito da eventual presença de algum fator interferente.

\subsubsection{Avaliação da maturação dentária}

O método utilizado neste estudo para a avaliação da maturação dos dentes permanentes nos grupos estudados foi o método proposto por DEMIRJIAN; GOLDSTEIN; TANNER ${ }^{26}$, em 1973, por sua simplicidade, ampla utilização e aceitação em nível mundial16,27,50,62,65,81,104,122 e por ser um método relativamente recente, quando comparado a outros métodos de abrangência similar. Neste método são avaliados os sete dentes permanentes do hemi-arco inferior esquerdo. Cada dente é classificado de acordo com o estágio de desenvolvimento no qual se encontra (variam de $\mathrm{A}$ a $\mathrm{H}$ ). A cada dente é atribuído um escore de acordo com o seu estágio de desenvolvimento. A soma desses sete escores fornece um escore de maturidade dentária, que pode ser convertido diretamente em idade dentária.

A idade dentária apresenta um interesse particular aos ortodontistas, no que tange o planejamento do tratamento das diferentes más oclusões em relação ao crescimento facia|26. Além disto, a determinação da idade dentária pode ajudar a identificar a idade de cadáveres, esqueletos, fósseis ${ }^{26}$ e facilita a comunicação e o entendimento dos dados obtidos por parte dos profissionais. Nas endocrinopatias pediátricas, o diagnóstico e os resultados do tratamento podem ser melhor interpretados se a idade dentária do paciente for considerada paralelamente à outros indicadores de maturidade 26 . 
De acordo com DEMIRJIAN; GOLDSTEIN; TANNER ${ }^{26}$, a conversão do escore de maturidade dentária em idade dentária deve ser realizada com cautela, pois esta conversão foi elaborada com base em uma população de jovens franco-canadenses, podendo haver variações dependendo da população considerada. Entretanto, o propósito deste estudo foi realizar uma comparação da maturação dentária (expressa em idade dentária) entre jovens com padrões de crescimento vertical e horizontal e não estimar a idade cronológica dos jovens a partir da idade dentária. Assim, a utilização deste método no presente estudo foi considerada bastante adequada.

\subsubsection{Idade média de erupção dos dentes permanentes}

O critério adotado para a erupção dentária foi o da emergência gengival, no qual um dente é considerado irrompido quando qualquer porção de sua coroa estiver visível na cavidade bucal. Este critério é prático e objetivo, possibilitando uma simples resposta sim/não e é amplamente utilizado nas pesquisas científicas relacionadas à erupção dentária $1,2,15,32,42,78,99,102,105,108,111,116,121$. Entretanto, como nesta pesquisa retrospectiva não foram realizados exames clínicos intrabucais dos jovens selecionados, o referido critério foi utilizado observando-se os modelos de gesso desses jovens. Outros estudos já relataram a utilização do critério da emergência gengival em modelos de gesso, obtendo resultados satisfatórios 56,114 .

O método de escolha para a seleção dos modelos de gesso foi o transversal, não havendo a preocupação de selecionar os modelos de um mesmo jovem em todas as idades estudadas. Alguns jovens apresentaram seus modelos de gesso selecionados em todas as idades pesquisadas, outros em apenas uma das idades consideradas, enquanto outros, em duas ou mais idades estudadas. A distribuição dos modelos de gesso nas idades dos 5 aos 13 anos, para cada grupo, pode ser observada na Tabela 1. Assim, obteve-se proporções de cada dente irrompido, para cada idade. De acordo com CAMPOS et al. ${ }^{13}$ e com CARRARA ${ }^{15}$, pode-se estudar a erupção dos dentes pelo método transversal, conseguindo-se boas estimativas, desde que se utilize 
uma técnica estatística adequada. CAMPOS et al. ${ }^{13}$ e CARR ${ }^{14}$ estudaram a erupção dentária por meio dos métodos longitudinal e transversal e não encontraram diferenças significantes entre esses dois métodos. Deste modo, o método transversal foi adotado nesta pesquisa sem prejudicar a obtenção dos resultados.

A idade média de erupção dos dentes permanentes foi determinada por meio do método de Karber, modificado por HAYES; MANTEL ${ }^{45}$, que em 1958 realizaram um estudo comparativo dos diversos métodos utilizados para 0 estudo da idade média de erupção dentária em amostras obtidas pelo método transversal. Os autores recomendaram a utilização do método de Karber, pela sua maior simplicidade e pelas boas estimativas conseguidas por meio dele. $\mathrm{O}$ método de Karber utiliza intervalos mensais entre as idades estudadas45; já CARRARA 15 utilizou intervalos trimestrais entre as idades estudadas, realizando adaptações na fórmula do método de Karber. Este método foi utilizado também por SOUZA FREITAS; ALVARES; LOPES108, em 1970, onde os autores utilizaram intervalos semestrais. No presente estudo, foram utilizados intervalos anuais entre as idades consideradas, a fim de que nenhuma idade ficasse descoberta. Isto poderia ocorrer se tivessem sido utilizados intervalos trimestrais ou mensais, pois, a amostra selecionada não apresentava número suficiente de pares de modelos para cobrir todos os intervalos das idades nestes casos. As conseqüências da utilização de intervalos anuais seriam um aumento dos desvios padrão das idades médias de erupção dos dentes permanentes e uma discreta diminuição da precisão dessas idades médias de erupção. No entanto, estas conseqüências não comprometem os resultados deste estudo, pois o objetivo do mesmo foi realizar uma comparação das idades médias de erupção dos dentes permanentes entre os jovens com padrões de crescimento vertical e horizontal e não estabelecer valores normativos para estas idades médias de erupção dos dentes permanentes. 


\subsubsection{Precisão da metodologia}

Foram realizadas quatro mensurações em cada telerradiografia dos 111 jovens selecionados, perfazendo um total de 444 medidas.

Para avaliar a precisão da metodologia, HOUSTON 47 sugere que se realize todas as mensurações duas vezes. Entretanto, se não for possível mensurar novamente todas as radiografias selecionadas, aconselha que se selecione radiografias da amostra total ao acaso. Neste estudo, foram traçadas e medidas novamente 20 telerradiografias escolhidas ao acaso, dentre as 111 da amostra total.

De uma maneira geral, os erros casuais na elaboração dos traçados cefalométricos e suas mensurações apresentaram-se reduzidos, estando todos abaixo de $1^{\circ}$ ou $1 \mathrm{~mm}$, o que foi considerado bastante satisfatório (Tabela 5). No entanto, houve diferença estatisticamente significante na avaliação do erro sistemático $(p<0,05)$ em uma das quatro medidas avaliadas, a saber, SN.GoGn (Tabela 5). Ao se adotar o nível de significância de $p<0,01$, esta variável não apresentou diferença estatisticamente significante entre as duas medições avaliadas. Além disso, a diferença entre as médias da primeira e da segunda medições foi de apenas $0,5250^{\circ}$, valor este considerado reduzido, não invalidando portanto, a metodologia utilizada.

Em relação ̀̀ radiografias panorâmicas, foram realizadas 7 classificações em cada uma das 60 radiografias utilizadas, que posteriormente foram convertidas em idade dentária, tornando-se um parâmetro possível de ser avaliado e comparado por meio de testes estatísticos paramétricos. Foram selecionadas ao acaso e avaliadas novamente 20 radiografias panorâmicas das 60 que constituíram a amostra total. Determinou-se as idades dentárias para cada um dos 20 jovens que tiveram suas radiografias panorâmicas reavaliadas. Posteriormente, esses dois valores foram comparados por meio do teste t pareado e pela aplicação da fórmula de DAHLBERG ${ }^{23}$, a fim de avaliar a precisão do método utilizado (Tabela 6). Os resultados obtidos foram bastante 
satisfatórios, estando o erro casual na ordem de 0,1643 e não havendo diferença estatisticamente significante na avaliação do erro sistemático.

\subsection{Os resultados obtidos}

\subsubsection{Resultados da análise cefalométrica}

A análise cefalométrica demonstrou que houve diferença estatisticamente significante (para $p<0,05$ e $p<0,01$ ) entre os grupos Vertical e Horizontal nas quatro variáveis analisadas, todas relacionadas ao padrão de crescimento facial (Tabela 7). Isto ressalta as diferenças marcantes existentes entre os dois grupos selecionados com os padrões de crescimento facial extremos.

\subsubsection{Resultados do estudo da maturação dentária}

Os resultados do presente estudo mostraram uma diferença estatisticamente significante (para $p<0,05$ e $p<0,01$ ) no desenvolvimento dentário entre os jovens com maior predomínio do vetor de crescimento vertical e aqueles com maior predomínio do vetor de crescimento horizontal (Tabela 8). O Grupo Vertical apresentou uma idade dentária média de 8,9567 anos, enquanto que no Grupo Horizontal, a idade dentária média encontrada foi de 8,1833 anos. Assim, observourse uma idade dentária mais avançada no Grupo Vertical, o que representa uma precocidade na maturação dentária pelos jovens com padrão de crescimento predominantemente vertical de 0,7733 anos em relação aos jovens com padrão de crescimento predominantemente horizontal. Esta precocidade equivale a aproximadamente 9 meses. Vale ressaltar que, uma idade dentária mais avançada reflete uma precocidade na maturação dentária.

NANDA ${ }^{83}$, em 1988, observou que jovens com mordida aberta esquelética e AFAI aumentada apresentavam uma precocidade na época do surto de crescimento pubescente em relação aos jovens com sobremordida profunda e AFAl diminuída. NANDA; ROWE84, em 1989, observaram que 
jovens com mordida aberta esquelética e AFAl aumentada apresentavam um maturação mais precoce do crescimento craniofacial em relação aos jovens com sobremordida profunda e AFAl diminuída. O trabalho de NANDA ${ }^{83}$, em 1988, e o trabalho de NANDA; ROWE ${ }^{84}$, publicado em 1989, motivaram JANSON et al.50 a investigarem se essa precocidade que os jovens com mordida aberta esquelética apresentaram na maturação do crescimento craniofacial, também ocorria na maturação dentária.

Os resultados da presente pesquisa vieram confirmar a tendência a uma precocidade na maturação dentária pelos jovens que apresentaram uma AFAI aumentada associada àmordida aberta esquelética em relação aos jovens que apresentaram uma AFAl diminuída associada à sobremordida profunda esquelética, observada por JANSON et al.50 em 1998. Este trabalho foi o único encontrado na literatura que realizou uma comparação da maturação dentária entre jovens com os tipos faciais verticais extremos.

JANSON et al.50 encontraram uma precocidade de 6 meses na maturação dentária dos jovens com mordida aberta esquelética em relação àqueles que apresentavam sobremordida profunda. Os autores consideraram esta diferença clinicamente significante, principalmente quando se faz referências ao tempo de tratamento. Logo, a diferença de 9 meses encontrada neste trabalho também apresenta-se clinicamente significante.

Quando se comparou a média das idades dentárias obtidas neste estudo com a média das idades cronológicas dos jovens, em cada um dos grupos considerados (Tabela 9), o Grupo Vertical apresentou uma idade dentária média mais avançada do que a idade cronológica média e esta diferença foi estatisticamente significante para $p<0,05$ e $p<0,01$. Já o Grupo Horizontal apresentou uma idade dentária média mais atrasada em relação à idade cronológica média e esta diferença também foi estatisticamente significante para $p<0,05$ e $p<0,01$. Assim, a utilização da idade cronológica nas tabelas de desenvolvimento dentário pode induzir o profissional a enganos, se não for considerado o tipo de padrão de crescimento individual50. A utilização da idade cronológica superestima a maturação dentária nos jovens que 
apresentam um predomínio do vetor de crescimento horizontal e, conseqüentemente, subestima o seu potencial de crescimento ${ }^{50}$. O inverso acontece para os jovens com predomínio do vetor de crescimento vertical. Os métodos utilizados para a predição do crescimento normalmente não consideram o fato de que os indivíduos com maturação menos avançada apresentam um maior potencial de crescimento e encontram-se em diferentes fases em suas curvas de crescimento 50,52 .

Segundo JANSON et al.50, a explicação para a precocidade da maturação dentária pelos jovens com padrão de crescimento vertical em relação àqueles com crescimento horizontal baseia-se principalmente nas características intrínsecas de cada um desses tipos faciais e na origem genética.

\subsubsection{Resultados da avaliação da erupção dentária}

O resultado da comparação das idades médias de erupção dos dentes permanentes entre os grupos Vertical e Horizontal não demonstrou grandes diferenças (Tabela 10). O Grupo Vertical apresentou uma idade média de erupção menor que o Grupo Horizontal em 16 dos 28 dentes considerados. A idade média de erupção dos dentes permanentes apresentou uma diferença estatisticamente significante entre os dois grupos estudados apenas para dois dentes, que foram os pré-molares superiores do lado esquerdo (dentes 24 e 25). Nestes dois casos, a idade média de erupção foi menor para o Grupo Vertical, representando uma precocidade na época da erupção dos prémolares superiores do lado esquerdo nos jovens com crescimento predominantemente vertical.

Uma vez que a maturação dos dentes permanentes no Grupo Vertical apresentou-se mais precoce (idade dentária mais avançada), esperava-se que esses dentes irrompessem mais precocemente neste referido grupo (idade média de erupção menor). Entretanto, o que se observou foram pequenas diferenças na idade média de erupção entre os grupos, com poucas exceções, ora o Grupo Vertical apresentando idades médias de erupção mais precoces, 
ora o Grupo Horizontal. Uma possível explicação para este fato é que a amostra para o estudo da erupção dentária não se apresentava tão característica como aquela utilizada para o estudo da maturação dentária.

No caso da amostra utilizada para se comparar a maturação dos dentes permanentes entre os grupos, foram selecionados os 60 jovens que apresentaram os valores extremos das grandezas cefalométricas relacionadas ao padrão de crescimento facial, selecionando desta maneira, os jovens com características marcantes do seu tipo de padrão de crescimento facial. Como a amostra para a avaliação da idade média de erupção dentária era maior (composta por 533 pares de modelos de gesso de 97 jovens), não foi possível selecionar apenas jovens com um predomínio acentuado de um determinado vetor de crescimento. Logo, a seleção também de jovens que apresentaram um predomínio suave de um vetor de crescimento facial pode ter sofrido influências de ambos os padrões de crescimento, tornando a amostra menos característica, pois, as características marcantes de cada tipo de padrão de crescimento podem ter sido mascaradas.

Além disto, pode ter havido influências de fatores locais (por exemplo, anquilose dentoalveolar do dente antecessor, perda prematura do dente decíduo, tratamento endodôntico do dente antecessor, entre outros) ou fatores gerais (distúrbios endócrinos, presença de alguma síndrome ou patologia sistêmica que possa alterar a fisiologia da erupção dentária, entre outros) sobre alguns dos jovens selecionados, apesar desta probabilidade ser a mesma para ambos os grupos.

Assim, torna-se necessário o desenvolvimento de novos estudos comparativos a respeito da idade média de erupção dos dentes permanentes em jovens com padrões de crescimento vertical e horizontal, utilizando idealmente uma amostra maior, com intervalos menores entre as idades estudadas e selecionando jovens com predomínio acentuado de cada um dos vetores de crescimento facial. 
Em cada grupo estudado avaliou-se a existência de dimorfismo de gênero para a idade média de erupção dos dentes permanentes. Esperava-se uma precocidade do gênero feminino para ambos os grupos, pois, na literatura pesquisada, parece haver um consenso entre os autores ao relatar este fato $12,14,17,18,29,32,34,42,46,48,55-57,72,74,78,102,103,108,112,113,116,117$, apesar de que em nenhum dos trabalhos consultados pesquisourse a existência de dimorfismo de gênero, considerando separadamente os jovens dos diferentes padrões de crescimento facial.

No Grupo Vertical, para 14 dos 28 dentes avaliados houve uma precocidade do gênero masculino na idade média de erupção e para os outros 14 dentes, houve uma precocidade do gênero feminino (Tabela 11). As diferenças das idades médias de erupção entre os gêneros foram bastante pequenas, sendo estatisticamente significantes apenas para os dentes 13, 24, 25, 36 e 46. Desses cinco dentes, apenas o dente 13 apresentou uma precocidade do gênero feminino na época de sua erupção, pois, a idade média de erupção desse dente no gênero feminino foi de 10,7261 anos e no gênero masculino foi de 11,3674 anos. Quando se adotou o nível de significância para $\mathrm{p}<0,01$, apenas $\mathrm{o}$ dente 25 apresentou uma diferença estatisticamente significante na idade média de erupção entre os gêneros, sendo que o gênero masculino irrompeu esse dente em uma idade média menor que o gênero feminino.

Já no Grupo Horizontal, os resultados relacionados ao dimorfismo de gênero apresentaram-se de acordo com o previsto, onde o gênero feminino antecedeu de uma maneira geral o gênero masculino na idade média de erupção dos dentes permanentes (Tabela 12). Todos os dentes permanentes apresentaram uma idade média de erupção mais precoce para o gênero feminino, com exceção do dente 15, que apresentou uma precocidade para o gênero masculino. No entanto, a diferença das idades médias de erupção do dente 15 entre os gêneros foi muito pequena $(0,1$ ano, o que equivale a aproximadamente 1 mês) e não foi estatisticamente significante. Houve dimorfismo de gênero estatisticamente significante para a idade média de erupção dos dentes $17,21,23,27,37,36,33,32,42,43,44,46$ e 47, todos 
apresentando uma precocidade do gênero feminino. Desses 13 dentes, 6 apresentaram diferenças estatisticamente significantes na idade média de erupção para $p<0,01$ : dentes 23, 37, 36, 43, 46 e 47.

Quando se comparou os jovens do gênero masculino do Grupo Vertical com os jovens também do gênero masculino do Grupo Horizontal, observou-se uma tendência dos jovens do Grupo Vertical apresentarem uma idade média de erupção dos dentes permanentes mais precoce que os jovens do Grupo Horizontal (Tabela 13). Dos 28 dentes estudados, em apenas três dentes o Grupo Horizontal apresentou idades médias mais precoces e as diferenças entre essas idades médias foram muito pequenas e não apresentaram significância estatística. Seis dentes (dentes 24, 25, 36, 43, 44 e 46) apresentaram diferença estatisticamente da idade média de erupção entre os grupos, sendo que em todos eles o Grupo Vertical apresentou idades médias de erupção mais precoces; desses seis dentes, apenas dois (dentes 24 e 25) apresentaram diferença estatisticamente significante para $p<0,01$.

Para as jovens do gênero feminino, observou-se uma tendência do Grupo Horizontal apresentar idades médias de erupção mais precoces que o Grupo Vertical, ao contrário dos resultados encontrados para o gênero masculino (Tabela 14). Dos 28 dentes avaliados, apenas quatro apresentaram uma precocidade da idade média de erupção no Grupo Vertical e as diferenças dessas idades médias de erupção entre os grupos, não se apresentaram estatisticamente significantes. Cinco dentes (dentes 27, 37, 36, 46 e 47) apresentaram diferenças estatisticamente significantes nas idades médias de erupção entre os grupos e para todos esses dentes houve uma precocidade do Grupo Horizontal. Desses cinco dentes, dois (dentes 37 e 47) apresentaram diferenças estatisticamente significantes entre os grupos estudados para $p<0,01$. Este resultado não era esperado, pois, de acordo com os resultados deste trabalho (Tabela 8 ) e com o trabalho realizado por JANSON et al. ${ }^{50}$, os jovens que apresentam um padrão de crescimento vertical maturam precocemente em relação aos jovens que apresentam um padrão de crescimento horizontal, independentemente do gênero. Como os jovens que apresentam um padrão de crescimento facial vertical maturam precocemente, 
esperava-se que seus dentes também irrompessem precocemente em relação aos jovens que apresentam um padrão de crescimento facial horizontal, independentemente do gênero, pois, a erupção dentária constitui apenas uma etapa do processo do desenvolvimento dentário.

Logo, torna-se conveniente o desenvolvimento de estudos futuros, no intuito de elucidar o comportamento de cada gênero nas idades médias de erupção em jovens com padrões de crescimento extremos. Obviamente, os resultados obtidos neste estudo em relação à idade média de erupção dos dentes permanentes não são conclusivos, mas estes resultados sugerem que há uma tendência do gênero masculino apresentar uma idade média de erupção dos dentes permanentes mais precoce em jovens com padrão de crescimento vertical do que naqueles com padrão de crescimento horizontal e o oposto parece ocorrer para o gênero feminino (Tabelas 13 e 14).

Em cada um dos grupos considerados realizou-se uma comparação das idades médias de erupção entre os dentes permanentes do lado direito e do lado esquerdo dos arcos dentários (Tabelas 15 e 16). Encontrourse uma correlação marcante da época de erupção entre os dentes permanentes dos lados direito e esquerdo, não sendo encontradas diferenças estatisticamente significantes entre as idades médias de erupção desses dentes, em ambos os grupos, com exceção do primeiro pré-molar superior no Grupo Vertical, que irrompeu em média 0,5 ano (equivalente a 6 meses) mais cedo no lado esquerdo. CATTELL17 em 1928, encontrou resultado semelhante, apesar de não ter separado os jovens em grupos de acordo com o tipo de padrão de crescimento facial, diferindo apenas no fato de que o primeiro pré-molar superior irrompeu em média 2 meses mais cedo no lado direito. Há um consenso da maioria dos autores em afirmar que há uma forte equivalência entre as idades médias de erupção dos dentes permanentes dos lados direito e esquerdo1,17,34,56,57,63,72,102,112,114, apesar de alguns autores como STONES et al. ${ }^{113}$ observarem uma leve tendência dos dentes do lado esquerdo irromperem antes que os do lado direito. 
Ao se comparar a idade média de erupção entre os dentes superiores e os inferiores, em ambos os grupos estudados, observou-se de uma maneira geral uma precocidade dos dentes inferiores (Tabelas 17 e 18). Esta precocidade foi mais marcante para os dentes anteriores, nos dois grupos, apresentando-se estatisticamente significante para $\mathrm{p}<0,05$ e $\mathrm{p}<0,01$ para os caninos e incisivos (Tabelas 17 e 18). Além dos dentes anteriores de ambos os grupos, apenas o segundo pré-molar esquerdo no Grupo Vertical e o segundo molar direito no Grupo Horizontal apresentaram diferenças estatisticamente significantes para $\mathrm{p}<0,05$ entre as idades médias de erupção dos dentes superiores e inferiores, porém, estas diferenças não foram estatisticamente significantes para $p<0,01$. Os segundos pré-molares do lado esquerdo no Grupo Vertical irromperam mais precocemente na maxila e os segundos molares direitos no Grupo Horizontal irromperam mais precocemente na mandíbula. No caso dos segundos pré-molares, esta precocidade na maxila torna-se compreensível, pois a seqüência mais comum de erupção dos dentes posteriores na maxila é: o primeiro pré-molar, o segundo pré-molar e depois o canino. Já na mandíbula, a seqüência mais comum é: o canino, o primeiro prémolar e depois o segundo pré-molar. Assim, o segundo pré-molar aparece mais tardiamente nesta seqüência na mandíbula, havendo uma ligeira precocidade de sua erupção na maxila em relação ao arco inferior.

$\mathrm{Na}$ literatura consultada, os autores são unânimes ao considerar a precocidade na idade média de erupção dos dentes inferiores em relação aos superiores $18,29,30,34,56,57,72,82,103,108,112,114$. No entanto, alguns autores consideram esta precocidade apenas para os dentes anteriores $29,34,56,114$. NANDA82 em 1960 observou que todos os dentes permanentes inferiores irromperam antes do que seus correspondentes superiores, com exceção dos

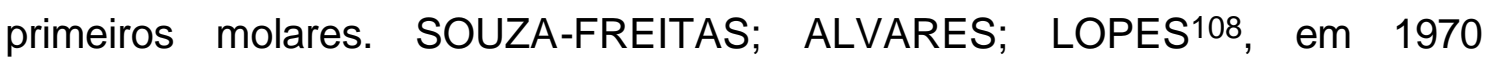
relataram que exceto para os primeiros e segundos pré-molares no gênero masculino e primeiro pré-molar no feminino, os dentes inferiores irromperam mais cedo que seus homólogos do arco superior. MARQUES; GUEDESPINTO; ABRAMOWICZ72 ${ }^{2}$ em 1978, e KOCHHAR; RICHARDSON57, em 1998, observaram que os dentes inferiores irromperam antes que seus correspondentes superiores, com exceção dos pré-molares. 
Uma vez obtidas as idades médias de erupção dos dentes permanentes (com exceção dos terceiros molares), torna-se possível a determinação da seqüência média de erupção desses dentes. Desta maneira, determinou-se a seqüência média de erupção para os dentes permanentes, em cada um dos grupos estudados, conforme expresso na Tabela 19.

TABELA 19 - Seqüência média de erupção dos dentes permanentes para os arcos superior e inferior nos grupos Vertical e Horizontal.

\begin{tabular}{c|c}
\hline \multicolumn{2}{c}{ GRUPO VERTICAL } \\
\hline MAXILA & $6-1-2-4-5-3-7$ \\
\hline MANDÍBULA & $1-6-2-3-4-5-7$ \\
\hline \multicolumn{2}{|c}{ GRUPO HORIZONTAL } \\
\hline MAXILA & $6-1-2-4-5-3-7$ \\
\hline MANDÍBULA & $6-1-2-3-4-5-7$ \\
\hline
\end{tabular}

As seqüências médias de erupção apresentaram-se bastante semelhantes entre os grupos, variando apenas a ordem de erupção entre os primeiros molares e incisivos centrais no arco inferior. Entretanto, de acordo com BURDI; MOYERS ${ }^{12}$, parece não haver significado clínico se a seqüência de erupção na mandíbula for 6-1 ou 1-6. SMITH; GARN105 atribuem esta variação ao curto intervalo de tempo existente entre a época de erupção desses dentes. BURDI; MOYERS 12 consideram que a velocidade na qual os incisivos irrompem é consideravelmente maior que aquela dos primeiros molares. Ao se observar um jovem com intervalos de 6 meses, por exemplo, pode parecer que 0 incisivo tenha irrompido primeiro, quando, na verdade, 0 primeiro molar o precedeu, mas ele se move tão lentamente que o incisivo 0 ultrapassa.

Para a maxila, vários autores $12,56,63,91,114,116$ encontraram a seqüência de erupção dentária 6-1-2-4-5-3-7 como a mais freqüente. Já para a mandíbula, alguns autores ${ }^{12,56,57,114}$ consideraram 1-6-2-3-4-5-7 como a seqüência de erupção mais freqüente, enquanto outros autores $12,63,91,116$ 
encontraram 6-1-2-3-4-5-7 mais freqüentemente. As seqüências de erupção 61-2-4-5-3-7 na maxila e 6-1-2-3-4-5-7 na mandíbula foram consideradas as mais favoráveis por alguns autores como LO; MOYERS 63 e PARREIRA et al. ${ }^{91}$. Existem várias outras possibilidades de seqüências de erupção dos dentes permanentes; por exemplo, LO; MOYERS63, em 1953, verificaram 18 seqüências de erupção diferentes para a maxila e 17 para a mandíbula. No entanto, estas variações não foram discutidas por apresentaram-se menos freqüentes e por diferirem das seqüências médias de erupção obtidas neste trabalho.

Torna-se notável a grande variabilidade que há entre os indivíduos em relação a época e seqüência de erupção dos dentes permanentes, fato este salientado na literatura por diversos pesquisadores 12,17,34,38,39,44,55,103,105,108,110,114. Esta variabilidade depende da interação de fatores ambientais e genéticos tais como a raça, o gênero, nutrição, fator econômico, condição sistêmica, condições locais e clima $39,103,108,110$. Isto denota a complexidade do estudo da erupção dos dentes permanentes.

\subsection{Considerações clínicas}

Uma implicação clínica dos resultados obtidos no presente estudo relaciona-se à época ideal para o início do tratamento ortodôntico e/ou ortopédico. Os pacientes que apresentam um padrão de crescimento facial predominantemente vertical podem iniciar o tratamento ortodôntico mais cedo que aqueles que apresentam um padrão de crescimento facial predominantemente horizontal, pois, as manifestações do surto de crescimento pubescente na face acontecem mais precocemente nos jovens com crescimento facial vertical83,84 e seus dentes permanentes maturam mais cedo do que nos jovens com padrão de crescimento horizontal, de acordo com os resultados deste trabalho e com aqueles obtidos por JANSON et al.50, em 1998. 
A precocidade da maturação dos dentes permanentes nos jovens com padrão de crescimento vertical deve ser especialmente considerada nos casos em que se deseja realizar um tratamento onde o paciente encontra-se em crescimento, onde se possa contar com o surto de crescimento pubescente em favor de melhores resultados no tratamento, o que ocorre, por exemplo, nos casos de tratamento ortopédico, tanto funcional como mecânico. Em alguns casos, por exemplo, quando se pretende distalizar os primeiros molares, deseja-se iniciar o tratamento ortodôntico antes da erupção dos segundos molares permanentes. Como os dentes permanentes maturam mais cedo nos jovens com crescimento vertical, espera-se que esses dentes permanentes irrompam mais cedo nestes jovens, apesar dos resultados deste estudo não terem comprovado este fato. Logo, torna-se importante observar o tipo de padrão de crescimento do paciente, para que se inicie o tratamento em uma época favorável a fim de se obter resultados satisfatórios.

Assim, para se determinar a época ideal para o início do tratamento ortodôntico e/ou ortopédico de um jovem, o profissional não deve se basear apenas na idade cronológica deste jovem, mas também em outros fatores como o gênero e o tipo de padrão de crescimento facial.

\subsection{Sugestões para trabalhos futuros}

- Comparar a idade média de erupção dos dentes permanentes entre jovens com padrões de crescimento predominantemente vertical e predominantemente horizontal, utilizando critérios para seleção da amostra e metodologia diferentes dos utilizados neste estudo.

- Comparar a maturação e a idade média de erupção dos dentes permanentes entre jovens com padrões de crescimento predominantemente vertical e predominantemente horizontal, para cada gênero separadamente, a fim de avaliar o comportamento dos gêneros no processo do desenvolvimento dentário nos diferentes tipos faciais. 


\section{Conclusões}




\section{CONCLUSÕES}

Os resultados obtidos neste estudo permitiram as seguintes conclusões:

- os jovens com padrão de crescimento predominantemente vertical apresentaram uma precocidade significante (de aproximadamente 9 meses) na maturação dos dentes permanentes em relação aos jovens com padrão de crescimento predominantemente horizontal;

- em relação à idade média de erupção dos dentes permanentes, os jovens com padrão de crescimento predominantemente vertical apresentaram uma precocidade estatisticamente significante apenas para os pré-molares superiores do lado esquerdo (dentes 24 e 25);

- a seqüência média de erupção dos dentes permanentes apresentou-se bastante semelhante entre os jovens com padrões de crescimento predominantemente vertical e predominantemente horizontal, diferindo apenas na ordem de erupção entre os primeiros molares e incisivos centrais no arco inferior. Nos jovens com padrão de crescimento vertical, os incisivos centrais irromperam antes dos primeiros molares. $\mathrm{O}$ inverso ocorreu para os jovens com crescimento horizontal. 


\section{Referências \\ Bibliográficas}




\section{REFERÊNCIAS BIBLIOGRÁFICAS*}

1. ABRAMOWICZ, M. Contribuição para o estudo da cronologia da erupção dos dentes permanentes, em Judeus do grupo étnico Ashkenazim, de níveis sócio-econômicos elevados. Sua aplicação na estimativa da idade. Rev. Fac. Odont. USP, v.2, n.1, p.91-146, jan.-jun. 1964.

2. ARBENZ, G.O.; ABRAMOWICZ, M. Contribuição para o estudo da seqüência e cronologia de erupção dos dentes permanentes. Estudo comparativo entre brasileiros brancos e Judeus Ashkenazim da cidade de São Paulo. Rev. Fac. Odont. USP, v.2, n.2, p.221-34, jul.-dez. 1964.

3. ARRUDA, C.C. et al. Desequilíbrio na rizogênese de pré-molares. Rev. Ass. paul. cirurg. Dent., v.54, n.1, p.55-60, jan./fev. 2000.

4. BECKER, A.; CHAUSHU, S. Dental age in maxillary canine ectopia. Amer. J. Orthodont. Dentofac. Orthop., v.117, n.6, p.657-62, June 2000.

5. BEKISZ, O.; DARIMONT, F.; ROMPEN, E.H. Diffuse but unilateral gingival enlargement associated with von Recklinghausen neurofibromatosis. A case report. J. clin. Periodont., v.27, n.5, p.361-5, May 2000.

6. BENGTSON, A.L.; BENGTSON, N.G. Dentes decíduos e o desvio na erupção. Rev. Ass. paul. cirurg. Dent., v.44, n.5, p.287-90, set./out. 1990.

7. BOSCO, V.L.; SILVA, R.H.H. Relação entre crescimento e erupção dentária. Rev. gaúcha. Odont., v.39, n.5, p.368-70, set./out. 1991.

\footnotetext{
* Normas recomendadas para uso no âmbito da Universidade de São Paulo, com base no documento "Referências Bibliográficas: exemplos", emanado do Conselho Supervisor do Sistema Integrado de Bibliotecas da USP, em reunião de 20 de setembro de 1990.
} 
8. BOSCO, V.L.; SILVA, R.H.H. Relação entre crescimento e erupção dentária. Rev. gaúcha. Odont., v.39, n.3, p.189-90, maio/jun. 1991.

9. BOSCO, V.L.; SILVA, R.H.H. Relação entre crescimento e erupção dentária. Rev. gaúcha. Odont., v.40, n.3, p.214-8, maio/jun. 1992.

10. BRADLEY, R.E. The relationship between eruption, calcification, and crowding of certain mandibular teeth. Angle Orthodont., v.31, n.4, p.230-36, Oct. 1961.

11. BROOK, A.H.; BARKER, D.K. Eruption of teeth among the racial groups of eastern New Guinea: a correlation of tooth eruption with calendar age. Arch. oral Biol., v.17, n.4, p.751-9, Apr. 1972.

12. BURDI, A.R.; MOYERS, R.E. Desenvolvimento da dentição e da oclusão. In: MOYERS, R.E. Ortodontia. 4.ed. Rio de Janeiro, Guanabara Koogan, c1991. Cap.6, p.86-126.

13. CAMPOS, S.M. et al. Comparação entre os métodos longitudinal e transversal, no estudo da cronologia e seqüência de erupção dos dentes primários. Rev. Fac. Farm. Odont. Ribeirão Preto, v.8, n.2, p.71-88, jul./dez. 1971.

14. CARR, L.M. Eruption ages of permanent teeth. Aust. dent. J., v.7, n.5, p.367-73, Oct. 1962.

15. CARRARA, C.F.D.C. Estudo da cronologia e seqüência de erupção e das agenesias dos dentes permanentes em indivíduos brasileiros, leucodermas, portadores de fissura transforame incisivo unilateral. Bauru, 2000. 107p. Dissertação (Mestrado) - Faculdade de Odontologia de Bauru, Universidade de São Paulo.

16. CARVALHO, A.A.F.; CARVALHO, A.; SANTOS-PINTO, M.C. Estudo radiográfico do desenvolvimento da dentição permanente de crianças 
brasileiras com idade cronológica variando entre 84 e 131 meses. Rev. Odont. UNESP, v.19, n.1, p.31-9, 1990.

17. CATTELL, P. The eruption and growth of the permanent teeth. J. dent. Res., v.8, n.2, p.279-87, Mar./Apr. 1928.

18. COHEN, J.T. The dates of eruption of the permanent teeth in a group of Minneapolis children: a preliminary report. J. Amer. dent. Ass., v.15, n.2, p.2337-41, July-Dec. 1928.

19. COLL, J.A.; SADRIAN, R. Predicting pulpectomy success and its relationship to exfoliation and succedaneous dentition. Pediat. Dent., v.18, n.1, p.57-63, Jan./Feb. 1996.

20. CORDEIRO, R.C.L. et al. Calcificação dos dentes permanentes em relação æ̀ idades óssea e cronológica em crianças. Rev. Ass. paul. cirurg. Dent., v.51, n.5, p.481-7, set./out. 1997.

21. CORDEIRO, R.C.L. et al. Estágios de calcificação e erupção de dentes permanentes de crianças da zona rural de Araraquara/SP. J. bras. Ortod. Ortop. maxilar, v.5, n.26, p.47-53, mar./abr. 2000.

22. COUTINHO, T.C.L.; SOUZA, I.P.R. Contribuição ao estudo da anquilose de molares decíduos em crianças e sua relação com os dentes permanentes sucessores. Rev. bras. Odont., v.51, n.5, p.18-23, set./out. 1994.

23. DAHLBERG, G. Statistical methods for medical and biological students. New York, Interscience, 1940.

24. DEMIRJIAN, A. et al. Interrelationships among measures of somatic, skeletal, dental, and sexual maturity. Amer. J. Orthodont., v.88, n.5, p.433-8, Nov. 1985. 
25. DEMIRJIAN, A.; GOLDSTEIN, H. New systems for dental maturity based on seven and four teeth. Ann. Hum. Biol., v.3, n.5, p.411-21, Sept. 1976.

26. DEMIRJIAN, A.; GOLDSTEIN, H.; TANNER, J.M. A new system of dental age assessment. Hum. Biol., v.45, n.2, p.211-27, May 1973.

27. DEMIRJIAN, A.; LEVESQUE, G.Y. Sexual differences in dental development and prediction of emergence. J. dent. Res., v.59, n.7, p.1110-22, May-Aug. 1980.

28. ELBADRAWY, H.E. Dental development in optimal and suboptimal fluoride communities. J. Canad. dent. Ass., v.50, n.2, p.761-4, Aug.-Dec. 1984.

29. ESKELI, R. et al. Standards for permanent tooth emergence in Finnish children. Angle Orthodont., v.69, n.6, p.529-33, Dec. 1999.

30. FERREIRA, F.V. Desenvolvimento da dentição. In: Ortodontia: diagnóstico e planejamento clínico. 3.ed. São Paulo, Artes Médicas, 1998. Cap.3, p.59-71.

31. FRANKLIN, D.L.; ROBERTS, G.J. Delayed tooth eruption in congenital hypertrichosis lanuginosa. Pediat. Dent., v.20, n.3, p.192-4, May/June 1998.

32. GALVÃO, C.A.A.N. Seqüência e cronologia da erupção de caninos e prémolares. Estudo em escolares na faixa etária de 10 a 15 anos. Rev. Odont. UNESP, v.20, n.1, p.227-36, 1991.

33. GARDUCCI, M.G.; LINO, A.P. Influência da fluoretação da água sobre os processos de rizólise e rizogênese. Rev. Ass. paul. cirurg. Dent., v.46, n.4, p.835-9, jul./ago. 1992. 
34. GARN, S.M.; BURDI, A.R. Prenatal ordering and postnatal sequence in dental development. J. dent. Res., v.50, n.6, p.1407-14, Nov./Dec. 1971.

35. GARN, S.M. et al. Variability of tooth formation. J. dent. Res., v.38, n.1, p.135-148, Jan./Feb. 1959.

36. GARN, S.M. et al. The sex difference in tooth calcification. J. dent. Res., v.37, n.3, p.561-7, June 1958.

37. GARN, S.M.; ROHMANN, C.G.; SILVERMAN, F.N. Radiografic standards for postnatal ossification and tooth calcification. Med. Radiogr. and Photogr., v.43, n.2, p.45-66, 1967.

38. GRABER, T.M. Crecimiento y desarrollo. In: Ortodontia: principios y práctica. 1.ed. Buenos Aires, Editorial Mundi, 1965. Cap. 2, p. 29-79.

39. GUEDES-PINTO, A.C. Erupção dentária. In: Odontopediatria. 6.ed. São Paulo, Ed. Santos, 1997. Cap.2, p.17-34.

40. GUSTAFSON, G.; KOCH, G. Age estimation up to 16 years of age based on dental development. Odont. Revy, v.25, n.3, p.297-306, 1974.

41. HÄGG, U.; TARANGER, J. Dental development assessed by tooth counts and its correlations to somatic development during puberty. Europ. J. Orthodont., v.6, n.1, p.55-64, Feb. 1984.

42. HÄGG, U.; TARANGER, J. Tooth counts and dental age. Angle Orthodont., v.55, n.2, p.93-107, Apr. 1985.

43. HARUKI, T.; KANOMI, R.; SHIMONO, T. The differences in the chronology and calcification of second molars between Angle class III 
and class II occlusions in Japanese children. J. Dent. Child., v.64, n.6, p.400-4, Nov./Dec. 1997.

44. HARVATI, K. Dental eruption sequence among Colombine Primates. Am. J. phys. Anthrop., v.112, n.1, p.69-85, May 2000.

45. HAYES, R.L.; MANTEL, N. Procedures for computing the mean age of eruption of human teeth. J. dent. Res., v.37, n.5, p.938-47, Sept./Oct. 1958.

46. HÖFFDING, J. et al. Emergence of permanent teeth and onset of dental stages in Japanese children. Community Dent. oral Epidem., v.12, n.1, p.55-8, Feb. 1984.

47. HOUSTON, W.J.B. The analysis of errors in orthodontic measurements. Am. J. Orthod., v.83, n.5, p.382-90, May 1983.

48. HURME, V.O. Ranges of normalcy in the eruption of permanent teeth. J. Dent. Child., v.16, n.2, p.11-5, Second Quarter 1949.

49. JACOBS, S.G. The impacted maxillary canine. Further observations on aetiology, radiographic localization, prevention/interception of impaction, and when to suspect impaction. Aust. dent. J., v.41, n.5, p.310-6, Oct. 1996.

50. JANSON, G.R.P. et al. Dental maturation in subjects with extreme vertical facial types. Europ. J. Orthodont., v.20, n.1, p.73-8, Feb. 1998.

51. JOHAL, A.S. Case report: infra-occluded deciduous molars: a review and alternative treatment approach. Europ. J. Prosthodont. Restorat. Dent., v.5, n.1, p.5-9, Mar. 1997.

52. JOHNSTON, L.E.J. A simplified approach to prediction. Amer. J. Orthodont., v.67, n.3, p.253-7, Mar. 1975. 
53. KALK, W.W.I.; BATENBURG, R.H.K.; VISSINK, A. Dentin dysplasia type I. Oral Surg., v.86, n.2, p.175-8, Aug. 1998.

54. KIESER, J.A.; GROENEVELD, H.T.; SILVA, P. Delayed tooth formation in children exposed to tobacco smoke. J. clin. pediat. Dent., v.20, n.2, p.97-100, Winter 1996.

55. KLEIN, H.; CODY, J.F. Graphic charts which depict the variations in numbers of erupted permanent teeth in grade school children. J. Amer. dent. Ass., v.26, n.4, p.609-11, Apr. 1939.

56. KNOTT, V.B.; MEREDITH, H.V. Statistics on eruption of the permanent dentition from serial data for North American white children. Angle Orthodont., v.36, n.1, p.68-79, Jan. 1966.

57. KOCHHAR, R.; RICHARDSON, A. The chronology and sequence of eruption of human permanent teeth in Northern Ireland. Int. J. Paed. Dent., v.8, n.4, p.243-52, Dec. 1998.

58. KRONFELD, S.M. The effects of premature loss of primary teeth and sequence of eruption of permanent teeth on malocclusion. J. Dent. Child., v.20, n.1, p.2-13, 1953.

59. KRUMHOLT, L.; ROED-PETERSEN, B.; PINDBORG, J.J. Eruption times of the permanent teeth in 622 Ugandan children. Arch. oral Biol., v.16, n.2, p.1281-8, July-Dec. 1971.

60. LEHTINEN, A. et al. Advanced dental maturity in children with juvenile rheumatoid arthritis. Eur. J. oral Sci., v.108, n.3, p.184-8, June 2000.

61. LEITE, I.C.G.; RODRIGUES, C.C. Anquilose em dentes decíduos: revisão literária e apresentação de casos clínicos. Rev. CROMG, v.3, n.2, p.53-5, jul.-dez. 1997. 
62. LIVERSIDGE, H.M. Dental maturation of 18th and 19th century British children using Demirjian's method. Int. J. Paed. Dent., v.9, n.2, p.111-5, June 1999.

63. LO, R.T.; MOYERS, R.E. Studies in the etiology and prevention of malocclusion. Amer. J. Orthodont., v.39, n.6, p.460-7, June 1953.

64. LOEVY, H.T. Maturation of permanent teeth in Black and Latino children. Acta odont. pediat., v.4, n.2, p.59-62, dic. 1983.

65. LOEVY, H.T. The effect of primary tooth extraction on the eruption of succedaneous premolars. J. Amer. dent. Ass., v.118, n.6, p.715-8, June 1989.

66. LOEVY, H.T.; CRAWFORD, J.G. Effect of pulpotomies on eruption of succedaneous premolars. Quintessence Int., v.22, n.10, p.795-800, Oct. 1991.

67. LOEVY, H.T.; GOLDBERG, A.F. Shifts in tooth maturation patterns in nonFrench Canadian boys. Int. J. Paed. Dent., v.9, n.2, p.105-10, June 1999.

68. LOGAN, W.J.G.; KRONFELD, R. Development of the human jaws and surrounding structures from birth to age of fifteen years. J. Amer. dent. Ass., v.20, n.3, p.379-427, Mar. 1933.

69. MAKI, K. et al. The impact of race on tooth formation. J. Dent. Child., v.66, n.5, p.353-6, Sept./Oct. 1999.

70. MAPPES, M.S.; HARRIS, E.F.; BEHRENTS, R.G. An example of regional variation in the tempos of tooth mineralization and hand-wrist ossification. Amer. J. Orthodont. Dentofac. Orthop., v.101, n.2, p.145-51, Feb. 1992. 
71. MARKS, S.C.; SCHROEDER, H.E. Tooth eruption: theories and facts. Anat. Rec., v.245, n.2, p.374-93, June 1996.

72. MARQUES, G.D.; GUEDES-PINTO, A.C.; ABRAMOWICZ, M. Estudo da cronologia de erupção dos dentes permanentes em crianças da cidade de São Paulo. Rev. Fac. Odont. USP, v.16, n.1, p.177-85, jan.-jun. 1978.

73. MARTINS, D.R. et al. Atlas de crescimento craniofacial. 1.ed. São Paulo, Ed. Santos, 1998.

74. MASSLER, M.; SCHOUR, I. Studies in tooth development: theories of eruption. Amer. J. Orthodont. oral Surg., v.27, p.552-76, Jan.-Dec. 1941.

75. MCCALL, J.O.; SCHOUR, I. Chronology of the human dentition. In: ORBAN, B. Oral histology and embriology. St. Louis, Mosby, 1944.

76. McNAMARA, C.M. et al. Premature dental eruption: report of case. J. Dent. Child., v.66, n.1, p.70-2, Jan./Feb. 1999.

77. McNAMARA, C.M. et al. Cleidocranial dysplasia: radiological appearances on dental panoramic radiography. Dentomaxillofac. Radiol., v.28, n.2, p.89-97, Mar. 1999.

78. MILLER, J.; HOBSON, P.; GASKELL, T.J. A serial study of the chronology of exfoliation of deciduous teeth and eruption of permanent teeth. Arch. oral Biol., v.10, n.5, p.805-18, Sept./Oct. 1965.

79. MOLINA, I.; VIÑAS, L.; GARCÍA-GODOY, F.M. Erupción clínica de los dientes permanentes en niños con impedimentos mentales de Santo Domingo. Acta odont. pediat., v.3, n.2, p.69-73, dic. 1982. 
80. MOORREES, C.F.A. et al. Age variation or formation stages for ten permanent teeth. J. dent. Res., v.42, n.6, p.1490-1502, Nov./Dec. 1963.

81. NADLER, G.L. Earlier dental maturation: fact or fiction? Angle Orthodont., v.68, n.6, p.535-8, Dec. 1998.

82. NANDA, R.S. Eruption of human teeth. Amer. J. Orthodont., v.46, n.5, p.363-78, May 1960.

83. NANDA, S.K. Patterns of vertical growth in the face. Amer. J. Orthodont. Dentofac. Orthop., v.93, n.2, p.103-16, Feb. 1988.

84. NANDA, S.K.; ROWE, T.K. Circumpubertal growth spurt related to vertical dysplasia. Angle Orthodont., v.59, n.2, p.113-22, Summer 1989.

85. NGAN, P.; ALKIRE, R.G.; FIELDS JR., H. Management of space problems in the primary and mixed dentitions. J. Amer. dent. Ass., v.130, n.9, p.1330-9, Sept. 1999.

86. NISWANDER, J.D. Effects of heredity and environment on development of dentition. J. dent. Res., v.42, p.1288-96, 1963. Supplement to no 6 .

87. NOLLA, C.M. The development of the permanent teeth. J. Dent. Child., v.27, n.4, p.254-66, Fourth quarter 1960.

88. O'CONNELL, A.C.; MARINI, J.C. Evaluation of oral problems in an osteogenesis imperfecta population. Oral Surg., v.87, n.2, p.189-96, Feb. 1999.

89. O'CONNELL, A.C. et al. Delayed eruption of permanent teeth in hyperimmunoglobulinemia E recurrent infection syndrome. Oral Surg., v.89, n.2, p.177-85, Feb. 2000. 
90. PACKOTA, G.V.; PHAROAH, M.J.; PETRIKOWSKI, C.G. Radiographic features of segmental odontomaxillary dysplasia. A study of 12 cases. Oral Surg., v.82, n.5, p.577-84, Nov. 1996.

91. PARREIRA, M.L.J. et al. Estudo da seqüência de erupção dos dentes permanentes em crianças - sexo masculino. Arch. Cent. Est. Curso Odont. Univ. Fed. M. Gerais, v.19, n.1, p.101-12, jan.-jun. 1982.

92. PEREIRA, R.M.; RODRIGUES, C.R.M.D. Prevalência de anquilose em molares decíduos nas crianças do município de São Paulo. Rev. paul. Odont., v.21, n.5, p.36-40, set./out. 1999.

93. PINHEIRO, G.A.; CASADO, L.E.M.; ASSUNÇÃO, V.A. Erupção dentária. Fenômeno fisiológico ou patológico? Odont. mod., v.20, n.3, p.28-33, mai./jun. 1993.

94. POSEN, A.L. The effect of premature loss of deciduous molars on premolar eruption. Angle Orthodont., v.35, n.3, p.249-52, July 1965.

95. RASMUSSEN, P.; KOTSAKI, A. Inherited retarded eruption in the permanent dentition. J. clin. pediat. Dent., v.21, n.3, p.205-11, Spring 1997.

96. RICHARDSON, M.E. Mesial migration of lower molars in relation to facial growth and eruption. Austr. Orthodont. J., v.14, n.2, p.87-91, Mar. 1996.

97. ROSENBLUM, S.H. Delayed dental development in a patient with Gorlin syndrome: case report. Pediat. Dent., v.20, n.5, p.355-8, Sept./Oct. 1998.

98. ROSSI, R.R.; AMORIM, S.G.; PACHECO, M.C.T. Correlação entre estágios de mineralização dos dentes e estimativa da maturação esquelética. Ortodontia, v.32, n.3, p.48-58, set.-dez. 1999. 
99. SALEEMI, M.A. et al. Dental development, dental age and tooth counts. A prospective longitudinal study of Pakistani children. Swed. dent. J., v.20, n.1-2, p.61-7, 1996.

100. SALIBA, C.A. et al. Estimativa da idade pela mineralização dos dentes, através de radiografias panorâmicas. ROBRAC, v.6, n.22, p.14-6, dez. 1997.

101. SATAKE, K.U.; SILVA, R.H.H. Relação entre crescimento e erupção dentária. Rev. gaúcha. Odont., v.38, n.3, p.183-7, maio/jun. 1990.

102. SAVARA, B.S.; STEEN, J.C. Timing and sequence of eruption of permanent teeth in a longitudinal sample of children from Oregon. J. Amer. dent. Ass., v.97, n.2, p.209-14, Aug. 1978.

103. SCHOUR, I.; MASSLER, M. The development of the human dentition. J. Amer. dent. Ass., v.28, n.7, p.1153-60, July 1941.

104. SILVA, G.C.H.; BOLOGNESE, A.M. Avaliação do surto de crescimento puberal através do exame clínico e radiográfico dos estágios de calcificação do segundo pré-molar inferior. Rev. Soc. bras. Ortodont., v.3, n.8, p.313-22, 1999.

105. SMITH, B.H.; GARN, S.M. Polymorphisms in eruption sequence of permanent teeth in American children. Amer. J. phys. Anthrop., v.74, n.3, p.289-303, Nov. 1987.

106. SO, L.L.Y. Correlation of sexual maturation with stature and body weight \& dental maturation in southern chinese girls. Austr. Orthodont. J., v.14, n.1, p.18-20, Oct. 1995.

107. SOUZA-FREITAS, J.A. Estudo das principais tabelas de avaliação da idade cronológica, através do desenvolvimento dental, visando sua aplicação em brasileiros leucodermas da região de Bauru. 
Bauru, 1969. 98p. Dissertação (Mestrado) - Faculdade de Odontologia de Bauru, Universidade de São Paulo.

108. SOUZA-FREITAS, J.A.; ALVARES, L.C.; LOPES, E.S. Aspectos da cronologia de erupção dos dentes permanentes em crianças brasileiras brancas de terceira geração. Estomat. Cult., v.4, n.2, p.201-8, jul.-dez. 1970.

109. SOUZA-FREITAS, J.A. et al. Variabilidade das fases de formação e erupção dos dentes permanentes. Ortodontia, v.23, n.2, p.29-39, maio-ago. 1990.

110. SOUZA-FREITAS, J.A. et al. Influência da fluoretação na cronologia de erupção dos dentes permanentes. Estomat. Cult., v.5, n.2, p.156-65, jul.-dez. 1971.

111. SOUZA-FREITAS, J.A.; LOPES, E.S.; DAMANTE, J.H. Cronologia de mineralização e de erupção dos dentes permanentes. Rev. bras. Odont., v.48, n.2, p.2-7, mar./abr. 1991.

112. STEGGERDA, M.; HILL, T.J. Eruption time of teeth among whites, negroes, and indians. Amer. J. Orthodont., v.28, n.6, p.361-70, June 1942.

113. STONES, H.H. et al. Time of eruption of permanent teeth and time of shedding of deciduous teeth. Brit. dent. J., v.90, n.1, p.1-7, Jan. 1951.

114. STURDIVANT, J.E.; KNOTT, V.B.; MEREDITH, H.V. Interrelations from serial data for eruption of the permanent dentition. Angle Orthodont., v.32, n.1, p.1-13, Jan. 1962.

115. SYMONS, A.L.; TAVERNE, A.A.R. A family case report: disturbances in tooth form and eruption of the second premolar. Austr. Orthodont. J., v.14, n.3, p.168-71, Oct. 1996. 
116. TITLEY, K.C. A comparative investigation of permanent tooth emergence timing of Northern Ontario Indians. J. Canad. dent. Ass., v.50, n.10, p.775-8, Oct. 1984.

117. TOLEDO, O.A. Aspectos da cronologia da erupção dos dentes permanentes em escolares primários, brasileiros, brancos, da cidade de Araçatuba. Considerações sobre o efeito da urbanização nas alterações da cronologia eruptiva. Araçatuba, 1963. 90p. Tese (Livre-Docência) - Faculdade de Farmácia e Odontologia de Araçatuba, Universidade Estadual Paulista.

118. TROTTER, M.; HIXON, B.B.; MACDONALD, B.J. Development and size of the teeth of Macaca mulatta. Amer. J. Anat., v.150, n.1, p.109-26, Sept. 1977.

119. VALLADARES-NETO, J.; SILVA, F.A.; KAADI, O.B. Retardo eruptivo de incisivo permanente associado à retenção prolongada do predecessor decíduo: obstrutivo, traumático, desenvolvimental ou idiopático? Discussão através de um caso clínico. ROBRAC, v.5, n.15, p.4-10, ago. 1995.

120. VIANNA, L.S. et al. Estudo da seqüência de erupção dos dentes permanentes em crianças do sexo feminino. Arch. Cent. Est. Curso Odont. Univ. Fed. M. Gerais, v.16, n.1/2, p.69-82, 1979.

121. VIRTANEN, J.I.; BLOIGU, R.S.; LARMAS, M.A. Timing of eruption of permanent teeth: standard finnish patient documents. Community Dent. oral Epidem., v.22, n.5 pt 1, p.286-8, Oct. 1994.

122. WEIDE, Y.S.; PRAHL-ANDERSEN, B.; BOSMAN, F. Tooth formation in patients with oligodontia. Angle Orthodont., v.63, n.1, p.31-7, Spring 1993. 
123. WEYMAN, J. The effect of irradiation on developing teeth. Oral Surg., v.25, n.4, p.623-9, Apr. 1968.

124. WISE, G.E. The biology of tooth eruption. J. dent. Res., v.77, n.8, p.1576-9, Aug. 1998.

125. YARED, F.N.F.G. Estudo das relações entre desenvolvimento somático e erupção dentária, em escolares caucasóides, da cidade de Araraquara, estado de São Paulo, segundo a faixa etária, o sexo e o nível sócio-econômico. Araraquara, 1994. 168p. Tese (Doutorado) - Faculdade de Odontologia de Araraquara, Universidade Estadual Paulista.

126. YONEMOCHI, H.; NODA, T.; SAKU, T. Pericoronal hamartomatous lesions in the opercula of teeth delayed in eruption: an immunohistochemical study of the extracellular matrix. J. oral Path. Med., v.27, n.9, p.441-52, Oct. 1998. 
Abstract 


\section{ABSTRACT}

\section{Comparative study of the maturation and eruption of permanent teeth in subjects with vertical and horizontal growth patterns}

The objective of this study was to compare the maturation stage and mean age of eruption of permanent teeth in Caucasian individuals with vertical and horizontal growth patterns. For that purpose, lateral cephalograms of 111 young subjects were selected in order to classify the individuals according to the facial growth pattern. The 30 subjects presenting the strongest predominance of vertical growth (15 males and 15 females), as well as the 30 presenting the strongest predominance of horizontal growth (15 males and 15 females) were selected, which comprised the vertical and horizontal groups, respectively. Panoramic radiographs of all individuals, obtained at 8 years of age (mean age 8.5067 years for the vertical group and 8.4800 for the horizontal group), were employed to evaluate the maturation of the permanent teeth, expressed by the dental age, according to the method of DEMIRJIAN; GOLDSTEIN; TANNER (1973). From the total sample of 111 young subjects, previously scored as to the facial growth pattern, 533 pairs of dental casts of 97 individuals ranging from 5 to 13 years of age were selected for evaluation of the mean age of eruption of the permanent teeth. These casts were assigned to two groups (vertical and horizontal). The mean age of eruption of the permanent teeth was calculated through Karber's method. Comparisons between groups were accomplished by means of independent $t$ tests. Results demonstrated a statistically significant difference between the dental age of the vertical and horizontal groups, with the vertical group presenting a more advanced dental age than the hrizontal. Regarding the mean age of eruption, among the 28 permanent teeth observed (excluding the third molars) only the left maxillary premolars demonstrated a statistically significant difference between the vertical and horizontal groups. Therefore, young subjects with vertical growth pattern should be expected to present earlier dental maturation than horizontal growers. 


\section{Apêndices}




\section{APÊNDICES}

As Tabelas A-1 e A-2 referem-se aos valores individuais das variáveis cefalométricas avaliadas, bem como a soma das mesmas e àclassificação de cada jovem de acordo com o tipo de padrão de crescimento facial.

A Tabela A-3 refere-se à atribuição dos estágios de desenvolvimento de cada dente avaliado, para cada jovem selecionado, dos grupos Vertical e Horizontal, bem como aos valores individuais dos escores de maturidade e das idades dentárias.

As Tabelas A-4 a A-21 referem-se à classificação dos dentes permanentes (do dente 17 ao 47) em presentes (P) ou ausentes (-), em todas as idades estudadas, para cada jovem de ambos os grupos considerados. Esta classificação em presente/ausente permite a obtenção da idade média e da seqüência média de erupção dos dentes permanentes, por meio da fórmula matemática do método de Karber. As tabelas que apresentam números pares referem-se aos dentes do arco superior, e as tabelas que apresentam números ímpares equivalem-se aos dentes do arco inferior. 
Tabela A-1

\begin{tabular}{|c|c|c|c|c|c|c|c|}
\hline Nome & Gênero & SN.GoGn & NS.Gn & FMA & AFAl & Soma & Classificação \\
\hline A. P. T. & $F$ & $44^{\circ}$ & $74,5^{\circ}$ & $42^{\circ}$ & $67 \mathrm{~mm}$ & 227,5 & Vertical \\
\hline J. M. R. M. & $\bar{M}$ & $41,5^{\circ}$ & $73^{\circ}$ & $33^{\circ}$ & $68,5 \mathrm{~mm}$ & 216 & Vertical \\
\hline G. R. C. & $\bar{M}$ & $35^{\circ}$ & $69,5^{\circ}$ & $33^{\circ}$ & $66,5 \mathrm{~mm}$ & 204 & Vertical \\
\hline F. B. A. & $\mathrm{F}$ & $35^{\circ}$ & $67^{\circ}$ & $28,5^{\circ}$ & $68 \mathrm{~mm}$ & 198,5 & Vertical \\
\hline M. F. G. & $F$ & $35^{\circ}$ & $72,5^{\circ}$ & $25,5^{\circ}$ & $65,5 \mathrm{~mm}$ & 198,5 & Vertical \\
\hline C. M. T. & $\bar{M}$ & $30^{\circ}$ & $67,5^{\circ}$ & $27,5^{\circ}$ & $62 \mathrm{~mm}$ & 187 & Horizontal \\
\hline V. M. A. C. & $\mathrm{F}$ & $35,5^{\circ}$ & $67^{\circ}$ & $26,5^{\circ}$ & $57 \mathrm{~mm}$ & 186 & Horizontal \\
\hline I. M. L. & $\mathrm{F}$ & $32^{\circ}$ & $64,5^{\circ}$ & $32^{\circ}$ & $61 \mathrm{~mm}$ & 189,5 & Horizontal \\
\hline A. C. M. & $\mathrm{F}$ & $40^{\circ}$ & $72,5^{\circ}$ & $33^{\circ}$ & $64 \mathrm{~mm}$ & 209,5 & Vertical \\
\hline C. S. D. & $\mathrm{F}$ & $31^{\circ}$ & $64^{\circ}$ & $24,5^{\circ}$ & $57 \mathrm{~mm}$ & 176,5 & Horizontal \\
\hline G. F. P. & $\mathrm{F}$ & $35,5^{\circ}$ & $70^{\circ}$ & $30^{\circ}$ & $63 \mathrm{~mm}$ & 198,5 & Vertical \\
\hline R. T. D. G. & $\bar{M}$ & $38^{\circ}$ & $70^{\circ}$ & $33^{\circ}$ & $63 \mathrm{~mm}$ & 204 & Vertical \\
\hline E. P. B. & $\mathrm{F}$ & $41,5^{\circ}$ & $71^{\circ}$ & $33,5^{\circ}$ & $64 \mathrm{~mm}$ & 210 & Vertical \\
\hline C. C. L. L. & $\bar{M}$ & $29,5^{\circ}$ & $63,5^{\circ}$ & $25^{\circ}$ & $62,5 \mathrm{~mm}$ & 180,5 & Horizontal \\
\hline A. F. G. & $\bar{M}$ & $41,5^{\circ}$ & $71^{\circ}$ & $36^{\circ}$ & $72 \mathrm{~mm}$ & 220,5 & Vertical \\
\hline A. B. S. M. & $\mathrm{F}$ & $30^{\circ}$ & $64^{\circ}$ & $26,5^{\circ}$ & $47,5 \mathrm{~mm}$ & 168 & Horizontal \\
\hline D. A. M. & $\bar{M}$ & $33^{\circ}$ & $66,5^{\circ}$ & $32^{\circ}$ & $63 \mathrm{~mm}$ & 194,5 & Horizontal \\
\hline G. C. T. N. & $\mathrm{M}$ & $37^{\circ}$ & $68^{\circ}$ & $33,5^{\circ}$ & $65,5 \mathrm{~mm}$ & 204 & Vertical \\
\hline R. A. A. & $\bar{M}$ & $40,5^{\circ}$ & $70,5^{\circ}$ & $33,5^{\circ}$ & $60 \mathrm{~mm}$ & 204,5 & Vertical \\
\hline A. G. M. & $\bar{M}$ & $38^{\circ}$ & $71^{\circ}$ & $35^{\circ}$ & $69,5 \mathrm{~mm}$ & 213,5 & Vertical \\
\hline F. C. B. & $\mathrm{F}$ & $41^{\circ}$ & $70,5^{\circ}$ & $29,5^{\circ}$ & $61 \mathrm{~mm}$ & 202 & Vertical \\
\hline A. I. M. B. & $\mathrm{F}$ & $39^{\circ}$ & $70^{\circ}$ & $33^{\circ}$ & $65 \mathrm{~mm}$ & 207 & Vertical \\
\hline S. T. G. & $\mathrm{M}$ & $32^{\circ}$ & $64^{\circ}$ & $29^{\circ}$ & $58 \mathrm{~mm}$ & 183 & Horizontal \\
\hline T. S. N. J. & $\mathrm{M}$ & $33^{\circ}$ & $69,5^{\circ}$ & $24^{\circ}$ & $68 \mathrm{~mm}$ & 194,5 & Horizontal \\
\hline D. E. H. & $F$ & $31,5^{\circ}$ & $65^{\circ}$ & $27^{\circ}$ & $54,5 \mathrm{~mm}$ & 178 & Horizontal \\
\hline D. F. C. & $F$ & $30,5^{\circ}$ & $64^{\circ}$ & $27^{\circ}$ & $57,5 \mathrm{~mm}$ & 179 & Horizontal \\
\hline P. S. E. & $\mathrm{F}$ & $32,5^{\circ}$ & $68^{\circ}$ & $23,5^{\circ}$ & $61 \mathrm{~mm}$ & 185 & Horizontal \\
\hline M. L. P. & $\mathrm{F}$ & $36^{\circ}$ & $67,5^{\circ}$ & $28^{\circ}$ & $57 \mathrm{~mm}$ & 188,5 & Horizontal \\
\hline F. L. B. & $\mathrm{F}$ & $37^{\circ}$ & $69,5^{\circ}$ & $31^{\circ}$ & $60,5 \mathrm{~mm}$ & 198 & Vertical \\
\hline D. F. D. & $\bar{M}$ & $39^{\circ}$ & $68^{\circ}$ & $34^{\circ}$ & $63 \mathrm{~mm}$ & 204 & Vertical \\
\hline D. A. M. & $\mathrm{M}$ & $36,5^{\circ}$ & $72^{\circ}$ & $30,5^{\circ}$ & $65 \mathrm{~mm}$ & 204 & Vertical \\
\hline R. P. F. & $\mathrm{M}$ & $30^{\circ}$ & $67^{\circ}$ & $22^{\circ}$ & $61,5 \mathrm{~mm}$ & 180,5 & Horizontal \\
\hline C. J. C. F. & $\mathrm{M}$ & $33^{\circ}$ & $66^{\circ}$ & $24,5^{\circ}$ & $63 \mathrm{~mm}$ & 186,5 & Horizontal \\
\hline P. B.J. & $\mathrm{M}$ & $40,5^{\circ}$ & $71^{\circ}$ & $31^{\circ}$ & $61 \mathrm{~mm}$ & 203,5 & Vertical \\
\hline M. P.P. & $F$ & $26^{\circ}$ & $63^{\circ}$ & $25^{\circ}$ & $57 \mathrm{~mm}$ & 171 & Horizontal \\
\hline A. P. M. B. & $\mathrm{F}$ & $29^{\circ}$ & $62^{\circ}$ & $23^{\circ}$ & $55 \mathrm{~mm}$ & 169 & Horizontal \\
\hline A. C. D. & $F$ & $31,5^{\circ}$ & $65^{\circ}$ & $31^{\circ}$ & $61 \mathrm{~mm}$ & 188,5 & Horizontal \\
\hline L. F. S. G. & $\mathrm{M}$ & $30^{\circ}$ & $62,5^{\circ}$ & $32^{\circ}$ & $64 \mathrm{~mm}$ & 188,5 & Horizontal \\
\hline J. C. M. J. & $\mathrm{M}$ & $35^{\circ}$ & $69^{\circ}$ & $32,5^{\circ}$ & $67 \mathrm{~mm}$ & 203,5 & Vertical \\
\hline A. L. T. P. & $\mathrm{F}$ & $40,5^{\circ}$ & $74^{\circ}$ & $34^{\circ}$ & $65,5 \mathrm{~mm}$ & 214 & Vertical \\
\hline E. D. B. & $F$ & $35,5^{\circ}$ & $68,5^{\circ}$ & $24,5^{\circ}$ & $56 \mathrm{~mm}$ & 184,5 & Horizontal \\
\hline T. V. S. & $\bar{M}$ & $44^{\circ}$ & $71^{\circ}$ & $41^{\circ}$ & $67 \mathrm{~mm}$ & 223 & Vertical \\
\hline C. B. J. & $\mathrm{F}$ & $32^{\circ}$ & $67,5^{\circ}$ & $29^{\circ}$ & $61 \mathrm{~mm}$ & 189,5 & Horizontal \\
\hline T. S. C. & $\mathrm{M}$ & $40^{\circ}$ & $68,5^{\circ}$ & $31,5^{\circ}$ & $64 \mathrm{~mm}$ & 204 & Vertical \\
\hline R. A. S. S. & $F$ & $36,5^{\circ}$ & $68,5^{\circ}$ & $31,5^{\circ}$ & $62 \mathrm{~mm}$ & 198,5 & Vertical \\
\hline P.S.P.C. & $\bar{M}$ & $39^{\circ}$ & $69^{\circ}$ & $34^{\circ}$ & $61,5 \mathrm{~mm}$ & 203,5 & Vertical \\
\hline M. A. P. T. & $\bar{M}$ & $36^{\circ}$ & $69^{\circ}$ & $32,5^{\circ}$ & $67,5 \mathrm{~mm}$ & 205 & Vertical \\
\hline R. A. C. M. & $\mathrm{M}$ & $33,5^{\circ}$ & $66^{\circ}$ & $26,5^{\circ}$ & $61,5 \mathrm{~mm}$ & 187,5 & Horizontal \\
\hline R. C. L. A. & $\mathrm{F}$ & $40^{\circ}$ & $70^{\circ}$ & $29^{\circ}$ & $59,5 \mathrm{~mm}$ & 198,5 & Vertical \\
\hline O. C. C. & $\mathrm{M}$ & $31^{\circ}$ & $69,5^{\circ}$ & $21,5^{\circ}$ & $60,5 \mathrm{~mm}$ & 182,5 & Horizontal \\
\hline R. Q. & $\bar{M}$ & $34^{\circ}$ & $65^{\circ}$ & $34,5^{\circ}$ & $70 \mathrm{~mm}$ & 203,5 & Vertical \\
\hline C. Q. & $\mathrm{F}$ & $36^{\circ}$ & $68^{\circ}$ & $31,5^{\circ}$ & $64 \mathrm{~mm}$ & 199,5 & Vertical \\
\hline R. A. A. P. R. & $\mathrm{F}$ & $36^{\circ}$ & $67,5^{\circ}$ & $31^{\circ}$ & $69,5 \mathrm{~mm}$ & 204 & Vertical \\
\hline J.R. N. & $\mathrm{M}$ & $34^{\circ}$ & $65,5^{\circ}$ & $30,5^{\circ}$ & $60 \mathrm{~mm}$ & 190 & Horizontal \\
\hline E. A. & $\mathrm{M}$ & $32,5^{\circ}$ & $67^{\circ}$ & $26^{\circ}$ & $60 \mathrm{~mm}$ & 185,5 & Horizontal \\
\hline T.F.D. & $\bar{M}$ & $25^{\circ}$ & $60,5^{\circ}$ & $21,5^{\circ}$ & $53,5 \mathrm{~mm}$ & 160,5 & Horizontal \\
\hline
\end{tabular}


Tabela A-2

\begin{tabular}{|c|c|c|c|c|c|c|c|}
\hline Nome & Gênero & SN.GoGn & NS.Gn & FMA & AFAl & Soma & Classificação \\
\hline G. S. M. & $\mathrm{M}$ & $39^{\circ}$ & $71^{\circ}$ & $35^{\circ}$ & $67 \mathrm{~mm}$ & 212 & Vertical \\
\hline M. Q. B. & $\mathrm{M}$ & $36^{\circ}$ & $66^{\circ}$ & $34,5^{\circ}$ & $67 \mathrm{~mm}$ & 203,5 & Vertical \\
\hline B. M. L. & $\bar{M}$ & $22^{\circ}$ & $59^{\circ}$ & $18^{\circ}$ & $56 \mathrm{~mm}$ & 155 & Horizontal \\
\hline J. A. R. C. M. & $\mathrm{M}$ & $31,5^{\circ}$ & $64,5^{\circ}$ & $27^{\circ}$ & $61 \mathrm{~mm}$ & 184 & Horizontal \\
\hline R. O. B. A. & $\mathrm{M}$ & $32,5^{\circ}$ & $67^{\circ}$ & $25^{\circ}$ & $63 \mathrm{~mm}$ & 187,5 & Horizontal \\
\hline H. J.S.S. & $\mathrm{M}$ & $38,5^{\circ}$ & $69^{\circ}$ & $31,5^{\circ}$ & $65 \mathrm{~mm}$ & 204 & Vertical \\
\hline R. G. M. & $\bar{M}$ & $39^{\circ}$ & $69^{\circ}$ & $32^{\circ}$ & $64 \mathrm{~mm}$ & 204 & Vertical \\
\hline E. L. C. S. & $\mathrm{M}$ & $38^{\circ}$ & $65,5^{\circ}$ & $30,5^{\circ}$ & $71 \mathrm{~mm}$ & 205 & Vertical \\
\hline J.A.A. C. & $\mathrm{M}$ & $32^{\circ}$ & $65,5^{\circ}$ & $27,5^{\circ}$ & $58,5 \mathrm{~mm}$ & 183,5 & Horizontal \\
\hline R. V. D. & $\bar{M}$ & $34,5^{\circ}$ & $66,5^{\circ}$ & $31^{\circ}$ & $57,5 \mathrm{~mm}$ & 189,5 & Horizontal \\
\hline R. F. B. & $\bar{M}$ & $33^{\circ}$ & $68^{\circ}$ & $23,5^{\circ}$ & $60 \mathrm{~mm}$ & 184,5 & Horizontal \\
\hline C. F. Z. S. & $\mathrm{F}$ & $27^{\circ}$ & $63,5^{\circ}$ & $23^{\circ}$ & $61,5 \mathrm{~mm}$ & 175 & Horizontal \\
\hline T. C. C. C. & $\mathrm{F}$ & $33^{\circ}$ & $67^{\circ}$ & $34^{\circ}$ & $64 \mathrm{~mm}$ & 198 & Vertical \\
\hline F. B. & $F$ & $35,5^{\circ}$ & $70^{\circ}$ & $24^{\circ}$ & $58 \mathrm{~mm}$ & 187,5 & Horizontal \\
\hline G. R. P. & $F$ & $26,5^{\circ}$ & $62^{\circ}$ & $23,5^{\circ}$ & $53 \mathrm{~mm}$ & 165 & Horizontal \\
\hline P. B. B. M. & $\mathrm{F}$ & $28,5^{\circ}$ & $63,5^{\circ}$ & $25,5^{\circ}$ & $63,5 \mathrm{~mm}$ & 181 & Horizontal \\
\hline A. P. B. & $\mathrm{F}$ & $48^{\circ}$ & $74,5^{\circ}$ & $37^{\circ}$ & $68 \mathrm{~mm}$ & 227,5 & Vertical \\
\hline R. B. R. & $F$ & $37^{\circ}$ & $72,5^{\circ}$ & $29^{\circ}$ & $60 \mathrm{~mm}$ & 198,5 & Vertical \\
\hline C. L. C. & $\mathrm{F}$ & $27,5^{\circ}$ & $66^{\circ}$ & $23^{\circ}$ & $58,5 \mathrm{~mm}$ & 175 & Horizontal \\
\hline R. T. V. P. B. & $\mathrm{F}$ & $32,5^{\circ}$ & $66^{\circ}$ & $22,5^{\circ}$ & $58,5 \mathrm{~mm}$ & 179,5 & Horizontal \\
\hline D. D. & $\mathrm{F}$ & $31^{\circ}$ & $62,5^{\circ}$ & $24^{\circ}$ & $57 \mathrm{~mm}$ & 174,5 & Horizontal \\
\hline A. Z. C. & $F$ & $34,5^{\circ}$ & $68^{\circ}$ & $25,5^{\circ}$ & $59 \mathrm{~mm}$ & 187 & Horizontal \\
\hline E. C. M. & $F$ & $40^{\circ}$ & $69^{\circ}$ & $36^{\circ}$ & $64,5 \mathrm{~mm}$ & 209,5 & Vertical \\
\hline L. B. & $\mathrm{F}$ & $34^{\circ}$ & $67,5^{\circ}$ & $28^{\circ}$ & $58,5 \mathrm{~mm}$ & 188 & Horizontal \\
\hline A. L. F. & $\bar{M}$ & $41^{\circ}$ & $74,5^{\circ}$ & $28^{\circ}$ & $60 \mathrm{~mm}$ & 203,5 & Vertical \\
\hline A. L. M. & $F$ & $38,5^{\circ}$ & $67^{\circ}$ & $32,5^{\circ}$ & $64 \mathrm{~mm}$ & 202 & Vertical \\
\hline M. C. C. & $\mathrm{F}$ & $32^{\circ}$ & $67,5^{\circ}$ & $21^{\circ}$ & $58 \mathrm{~mm}$ & 178,5 & Horizontal \\
\hline L. C. V. & $\mathrm{F}$ & $35^{\circ}$ & $69^{\circ}$ & $29,5^{\circ}$ & $64,5 \mathrm{~mm}$ & 198 & Vertical \\
\hline F. R. O. & $\bar{M}$ & $22^{\circ}$ & $62^{\circ}$ & $16^{\circ}$ & $55 \mathrm{~mm}$ & 155 & Horizontal \\
\hline A. R. F. & $\bar{M}$ & $38^{\circ}$ & $71,5^{\circ}$ & $29,5^{\circ}$ & $67 \mathrm{~mm}$ & 206 & Vertical \\
\hline F.S. & $\bar{M}$ & $33^{\circ}$ & $66,5^{\circ}$ & $30,5^{\circ}$ & $61,5 \mathrm{~mm}$ & 191,5 & Horizontal \\
\hline E. S.P. & $\bar{M}$ & $40,5^{\circ}$ & $66,5^{\circ}$ & $32^{\circ}$ & $67 \mathrm{~mm}$ & 206 & Vertical \\
\hline M. S. & $\bar{M}$ & $39^{\circ}$ & $71^{\circ}$ & $37,5^{\circ}$ & $62 \mathrm{~mm}$ & 209,5 & Vertical \\
\hline W. A. P. J. & $\mathrm{M}$ & $40^{\circ}$ & $69,5^{\circ}$ & $34^{\circ}$ & $68,5 \mathrm{~mm}$ & 212 & Vertical \\
\hline F. B. C. & $\mathrm{M}$ & $29,5^{\circ}$ & $66^{\circ}$ & $28^{\circ}$ & $63 \mathrm{~mm}$ & 186,5 & Horizontal \\
\hline M. G. T. & $\overline{\mathrm{M}}$ & $34^{\circ}$ & $69^{\circ}$ & $31,5^{\circ}$ & $69,5 \mathrm{~mm}$ & 204 & Vertical \\
\hline M. T. & $\bar{M}$ & $28^{\circ}$ & $61^{\circ}$ & $27,5^{\circ}$ & $58 \mathrm{~mm}$ & 174,5 & Horizontal \\
\hline M. H. T. & $\mathrm{F}$ & $29,5^{\circ}$ & $64^{\circ}$ & $29,5^{\circ}$ & $59 \mathrm{~mm}$ & 182 & Horizontal \\
\hline R. D. S. & $F$ & $31,5^{\circ}$ & $68,5^{\circ}$ & $24,5^{\circ}$ & $63 \mathrm{~mm}$ & 187,5 & Horizontal \\
\hline D. C. G. O. & $\mathrm{F}$ & $44^{\circ}$ & $76^{\circ}$ & $35^{\circ}$ & $69 \mathrm{~mm}$ & 224 & Vertical \\
\hline C. B. & $\mathrm{F}$ & $27,5^{\circ}$ & $65,5^{\circ}$ & $18^{\circ}$ & $61 \mathrm{~mm}$ & 172 & Horizontal \\
\hline E. F. Z. & $F$ & $38^{\circ}$ & $72^{\circ}$ & $27,5^{\circ}$ & $61 \mathrm{~mm}$ & 198,5 & Vertical \\
\hline C. C. P. & $F$ & $38,5^{\circ}$ & $67^{\circ}$ & $30,5^{\circ}$ & $62 \mathrm{~mm}$ & 198 & Vertical \\
\hline C. V. E. & $\mathrm{F}$ & $34,5^{\circ}$ & $68^{\circ}$ & $26,5^{\circ}$ & $69,5 \mathrm{~mm}$ & 198,5 & Vertical \\
\hline S. D. & $\mathrm{F}$ & $38^{\circ}$ & $66,5^{\circ}$ & $36^{\circ}$ & $60 \mathrm{~mm}$ & 200,5 & Vertical \\
\hline F. B.R. & $F$ & $38,5^{\circ}$ & $72^{\circ}$ & $32^{\circ}$ & $57 \mathrm{~mm}$ & 199,5 & Vertical \\
\hline F. Z. & $\bar{M}$ & $36^{\circ}$ & $65^{\circ}$ & $34^{\circ}$ & $70 \mathrm{~mm}$ & 205 & Vertical \\
\hline W. R. N. & $\bar{M}$ & $38^{\circ}$ & $68^{\circ}$ & $26^{\circ}$ & $58 \mathrm{~mm}$ & 190 & Horizontal \\
\hline F. A. D. & $M$ & $31^{\circ}$ & $68^{\circ}$ & $28^{\circ}$ & $62,5 \mathrm{~mm}$ & 189,5 & Horizontal \\
\hline A. P. E. & $F$ & $39^{\circ}$ & $69^{\circ}$ & $30^{\circ}$ & $65,5 \mathrm{~mm}$ & 203,5 & Vertical \\
\hline E. C. L. & $\mathrm{F}$ & $30,5^{\circ}$ & $63^{\circ}$ & $25^{\circ}$ & $62 \mathrm{~mm}$ & 180,5 & Horizontal \\
\hline E. B. B. & $F$ & $24^{\circ}$ & $63^{\circ}$ & $18,5^{\circ}$ & $55 \mathrm{~mm}$ & 160,5 & Horizontal \\
\hline V. C. P. & $F$ & $33,5^{\circ}$ & $68,5^{\circ}$ & $25,5^{\circ}$ & $61 \mathrm{~mm}$ & 188,5 & Horizontal \\
\hline R. R. D. & $\bar{M}$ & $32^{\circ}$ & $64^{\circ}$ & $28^{\circ}$ & $57 \mathrm{~mm}$ & 181 & Horizontal \\
\hline R. F. E. & $\mathrm{M}$ & $33^{\circ}$ & $64,5^{\circ}$ & $26^{\circ}$ & $66,5 \mathrm{~mm}$ & 190 & Horizontal \\
\hline
\end{tabular}


Tabela A-3

\begin{tabular}{|c|c|c|c|c|c|c|c|c|c|c|c|c|}
\hline NOME & GRUPO & GËNERO & IDADE & 31 & 32 & 33 & 34 & 35 & 36 & 37 & ESCORE & ID. DENT. \\
\hline A. P. T. & $\mathrm{V}$ & $\mathrm{F}$ & 8,5 & $\mathrm{H}$ & $G$ & $\mathrm{~F}$ & $\mathrm{~F}$ & $E$ & $\mathrm{G}$ & $\mathrm{D}$ & 86,3 & 8,8 \\
\hline A. C. M. & $\mathrm{V}$ & $\mathrm{F}$ & 8,6 & $\mathrm{H}$ & $G$ & $\mathrm{~F}$ & $\mathrm{~F}$ & $F$ & $G$ & $E$ & 89,5 & 9,4 \\
\hline E. P. B. & $\mathrm{V}$ & $\mathrm{F}$ & 8,8 & $\mathrm{H}$ & $\mathrm{G}$ & $\mathrm{F}$ & $\mathrm{F}$ & $\mathrm{E}$ & $\mathrm{H}$ & $E$ & 90,9 & 9,7 \\
\hline F. C. B. & $\mathrm{V}$ & $\mathrm{F}$ & 8,4 & $\mathrm{H}$ & $\mathrm{G}$ & $\mathrm{F}$ & $E$ & $E$ & $\mathrm{G}$ & $E$ & 87,4 & 9,0 \\
\hline A. I. M. B. & $\mathrm{V}$ & $\mathrm{F}$ & 8,4 & $\mathrm{H}$ & $G$ & $\mathrm{~F}$ & $\mathrm{~F}$ & $E$ & $G$ & $E$ & 88,7 & 9,3 \\
\hline A. L. T. P. & $\mathrm{V}$ & $\mathrm{F}$ & 8,3 & $\mathrm{H}$ & $\mathrm{G}$ & $\mathrm{F}$ & $E$ & $\mathrm{D}$ & $\mathrm{G}$ & $\mathrm{D}$ & 82,9 & 8,4 \\
\hline C. Q. & $\mathrm{V}$ & $\mathrm{F}$ & 8,3 & $G$ & $G$ & $\mathrm{~F}$ & $\mathrm{E}$ & $E$ & $G$ & $\mathrm{D}$ & 81,4 & 8,2 \\
\hline R. A. A. P. R. & V & $F$ & 8,9 & $\mathrm{H}$ & $\mathrm{G}$ & $\mathrm{F}$ & $E$ & $E$ & $\mathrm{G}$ & $E$ & 87,4 & 9,0 \\
\hline A. P. B. & V & $\mathrm{F}$ & 8,6 & $\mathrm{H}$ & $\mathrm{H}$ & $\mathrm{F}$ & $\mathrm{F}$ & $\mathrm{F}$ & $\mathrm{H}$ & $\mathrm{F}$ & 94,4 & 11,0 \\
\hline E. C. M. & $\mathrm{V}$ & $\mathrm{F}$ & 8,9 & $\mathrm{H}$ & $\mathrm{G}$ & $\mathrm{F}$ & $\mathrm{F}$ & $E$ & $\mathrm{G}$ & $\mathrm{E}$ & 88,7 & 9,3 \\
\hline A. L. M. & $\mathrm{V}$ & $\mathrm{F}$ & 8,2 & $G$ & $G$ & $\mathrm{E}$ & $\mathrm{E}$ & $E$ & $G$ & $\mathrm{E}$ & 80,8 & 8,2 \\
\hline D. C. G. O. & $\mathrm{V}$ & $\mathrm{F}$ & 8,2 & $\mathrm{G}$ & $\mathrm{F}$ & $E$ & $E$ & $E$ & $\mathrm{G}$ & $\mathrm{D}$ & 74,2 & 7,8 \\
\hline S.D. & $\mathrm{V}$ & $\mathrm{F}$ & 8,9 & $\mathrm{H}$ & $\mathrm{G}$ & $\mathrm{E}$ & $\mathrm{E}$ & $E$ & $\mathrm{G}$ & $\mathrm{D}$ & 82,0 & 8,3 \\
\hline F. B. R. & $\mathrm{V}$ & $\mathrm{F}$ & 8,9 & $\mathrm{H}$ & $\mathrm{G}$ & $\mathrm{E}$ & $\mathrm{E}$ & $E$ & $\mathrm{G}$ & $\mathrm{D}$ & 82,0 & 8,3 \\
\hline A. P. E. & $\mathrm{V}$ & $\mathrm{F}$ & 8,2 & $\mathrm{H}$ & $G$ & $\mathrm{~F}$ & $\mathrm{~F}$ & $E$ & $G$ & $\mathrm{E}$ & 88,7 & 9,3 \\
\hline J. M. R. M. & $\mathrm{V}$ & $\mathrm{M}$ & 8,7 & $\mathrm{H}$ & $\mathrm{G}$ & $\mathrm{G}$ & $\mathrm{F}$ & $\mathrm{F}$ & $\mathrm{G}$ & $E$ & 89,1 & 10,0 \\
\hline A. F. G. & $\mathrm{V}$ & $M$ & 8,5 & $\mathrm{H}$ & $\mathrm{G}$ & $\mathrm{F}$ & $\mathrm{F}$ & $E$ & $\mathrm{G}$ & $E$ & 87,3 & 9,6 \\
\hline R. A. A. & $\mathrm{V}$ & $\mathrm{M}$ & 8,8 & $G$ & $\mathrm{G}$ & $\mathrm{E}$ & $\mathrm{E}$ & $E$ & $\mathrm{G}$ & $\mathrm{D}$ & 77,9 & 8,4 \\
\hline A. G. M. & $\mathrm{V}$ & $\mathrm{M}$ & 8,4 & $\mathrm{G}$ & $\mathrm{G}$ & $\mathrm{F}$ & $E$ & $E$ & $\mathrm{G}$ & $E$ & 82,4 & 8,9 \\
\hline D. F. D. & V & $\mathrm{M}$ & 8,0 & $\mathrm{G}$ & $\mathrm{F}$ & $E$ & $E$ & $E$ & $\mathrm{G}$ & $\mathrm{D}$ & 74,0 & 8,1 \\
\hline T. V.S. & $\mathrm{V}$ & $\mathrm{M}$ & 8,0 & $\mathrm{G}$ & $\mathrm{G}$ & $E$ & $E$ & $\bar{E}$ & $\mathrm{G}$ & $E$ & 80,3 & 8,6 \\
\hline M. A.P. T. & $\mathrm{V}$ & $\mathrm{M}$ & 8,0 & $\mathrm{H}$ & $G$ & $\mathrm{~F}$ & $\mathrm{E}$ & $E$ & $G$ & $\mathrm{D}$ & 83,6 & 9,0 \\
\hline G. S. M. & $\mathrm{V}$ & $\mathrm{M}$ & 8,5 & $\mathrm{G}$ & $\mathrm{F}$ & $E$ & $E$ & $E$ & $\mathrm{G}$ & $\mathrm{D}$ & 74,0 & 8,1 \\
\hline E. L. C.S. & $\mathrm{V}$ & $\bar{M}$ & 8,9 & $\mathrm{H}$ & $\mathrm{G}$ & $\mathrm{F}$ & $\mathrm{F}$ & $E$ & $\mathrm{G}$ & $\mathrm{E}$ & 87,3 & 9,6 \\
\hline A. R. F. & $\mathrm{V}$ & $M$ & 8,9 & $\mathrm{H}$ & $\mathrm{G}$ & $\mathrm{F}$ & $E$ & $E$ & $\mathrm{G}$ & $\mathrm{E}$ & 86,0 & 9,4 \\
\hline E. S.P. & $\mathrm{V}$ & $\mathrm{M}$ & 8,0 & $G$ & $\mathrm{~F}$ & $E$ & $E$ & $E$ & $G$ & $\mathrm{D}$ & 74,0 & 8,1 \\
\hline M. S. & $\mathrm{V}$ & $\bar{M}$ & 8,1 & $\mathrm{G}$ & $\mathrm{F}$ & $E$ & $E$ & $E$ & $\mathrm{G}$ & $E$ & 76,4 & 8,3 \\
\hline W. A.P. J. & $\mathrm{V}$ & $\mathrm{M}$ & 8,1 & $\mathrm{H}$ & $G$ & $E$ & $E$ & $\mathrm{D}$ & $G$ & $E$ & 81,6 & 8,8 \\
\hline M. G.T. & $\mathrm{V}$ & $\mathrm{M}$ & 8,6 & $\mathrm{H}$ & $\mathrm{G}$ & $\mathrm{F}$ & $\mathrm{F}$ & $\mathrm{F}$ & $\mathrm{G}$ & $\mathrm{F}$ & 88,8 & 10,0 \\
\hline F. Z. & $\mathrm{V}$ & $M$ & 8,7 & $\mathrm{H}$ & $\mathrm{G}$ & $\mathrm{F}$ & $\mathrm{F}$ & $\mathrm{F}$ & $\mathrm{G}$ & $E$ & 88,1 & 9,8 \\
\hline V. M. A. C. & $\mathrm{H}$ & $\mathrm{F}$ & 8,6 & $\mathrm{~F}$ & $\mathrm{E}$ & $\mathrm{E}$ & $\mathrm{D}$ & $\mathrm{B}$ & $\mathrm{F}$ & $\mathrm{C}$ & 44,8 & 6,6 \\
\hline C. S. D. & $\mathrm{H}$ & $\mathrm{F}$ & 8,0 & $G$ & $\mathrm{~F}$ & $\mathrm{~F}$ & $E$ & $\mathrm{D}$ & $G$ & $\mathrm{E}$ & 77,5 & 7,9 \\
\hline A. B. S. M. & $\mathrm{H}$ & $\mathrm{F}$ & 8,9 & $\mathrm{~F}$ & $E$ & $\mathrm{E}$ & $\mathrm{E}$ & $\mathrm{D}$ & $G$ & $\mathrm{D}$ & 65,5 & 7,5 \\
\hline D. F. C. & $\mathrm{H}$ & $\mathrm{F}$ & 8,1 & $\mathrm{G}$ & $\mathrm{F}$ & $\mathrm{F}$ & $E$ & $\mathrm{D}$ & $\mathrm{G}$ & $\mathrm{C}$ & 70,9 & 7,7 \\
\hline P.S.E. & $\mathrm{H}$ & $\mathrm{F}$ & 8,4 & $G$ & $\mathrm{~F}$ & $\mathrm{~F}$ & $\mathrm{~F}$ & $\mathrm{E}$ & $G$ & $E$ & 80,9 & 8,2 \\
\hline M. P.P. & $\mathrm{H}$ & $\mathrm{F}$ & 8,5 & $\mathrm{G}$ & $\mathrm{F}$ & $\mathrm{F}$ & $E$ & $\mathrm{C}$ & $\mathrm{G}$ & $\mathrm{D}$ & 71,0 & 7,7 \\
\hline A. P. M. B. & $\mathrm{H}$ & $\mathrm{F}$ & 8,0 & $G$ & $\mathrm{~F}$ & $\mathrm{~F}$ & $\mathrm{~F}$ & $\mathrm{E}$ & $G$ & $E$ & 80,9 & 8,2 \\
\hline E. D. B. & $\mathrm{H}$ & $\mathrm{F}$ & 8,8 & $\mathrm{G}$ & $\mathrm{F}$ & $\mathrm{F}$ & $E$ & $\mathrm{C}$ & $\mathrm{G}$ & $\mathrm{D}$ & 71,0 & 7,7 \\
\hline P. B. B. M. & $\mathrm{H}$ & $\mathrm{F}$ & 8,8 & $\mathrm{G}$ & $\mathrm{F}$ & $\mathrm{F}$ & $\mathrm{E}$ & $\mathrm{D}$ & $\mathrm{G}$ & $\mathrm{E}$ & 77,5 & 7,9 \\
\hline R. T. V.P. B. & $\mathrm{H}$ & $\mathrm{F}$ & 8,1 & $\mathrm{H}$ & $\mathrm{G}$ & $\mathrm{F}$ & $E$ & $E$ & $\mathrm{G}$ & $\mathrm{D}$ & 85,0 & 8,7 \\
\hline D. D. & $\mathrm{H}$ & $\mathrm{F}$ & 8,5 & $\mathrm{H}$ & $G$ & $\mathrm{~F}$ & $\mathrm{~F}$ & $\mathrm{D}$ & $\mathrm{G}$ & $\mathrm{D}$ & 84,2 & 8,5 \\
\hline L. B. & $\mathrm{H}$ & $\mathrm{F}$ & 8,6 & $\mathrm{G}$ & $\mathrm{F}$ & $\mathrm{F}$ & $E$ & $E$ & $\bar{G}$ & $E$ & 79,6 & 8,1 \\
\hline M. C. C. & $\mathrm{H}$ & $\mathrm{F}$ & 8,1 & $\mathrm{H}$ & $G$ & $\mathrm{~F}$ & $E$ & $E$ & $G$ & $E$ & 87,4 & 9,0 \\
\hline C. B. & $\mathrm{H}$ & $\mathrm{F}$ & 8,4 & $\mathrm{G}$ & $\mathrm{G}$ & $\mathrm{F}$ & $E$ & $E$ & $\mathrm{G}$ & $\mathrm{D}$ & 81,4 & 8,2 \\
\hline E. C. L. & $\mathrm{H}$ & $\mathrm{F}$ & 8,6 & $G$ & $G$ & $\mathrm{~F}$ & $E$ & $E$ & $G$ & $E$ & 83,8 & 8,5 \\
\hline C. C. L. L. & $\mathrm{H}$ & $\bar{M}$ & 8,2 & $\mathrm{G}$ & $\mathrm{G}$ & $\mathrm{E}$ & $E$ & $\mathrm{D}$ & $\mathrm{G}$ & $\mathrm{E}$ & 78,0 & 8,4 \\
\hline R.P.F. & $\mathrm{H}$ & $M$ & 8,8 & $\mathrm{H}$ & $\mathrm{G}$ & $\mathrm{E}$ & $\mathrm{E}$ & $\mathrm{D}$ & $\mathrm{G}$ & $\mathrm{D}$ & 79,2 & 8,5 \\
\hline C.J. C.F. & $\mathrm{H}$ & $\mathrm{M}$ & 8,3 & $G$ & $\mathrm{G}$ & $\mathrm{F}$ & $\mathrm{F}$ & $E$ & $\mathrm{G}$ & $E$ & 83,7 & 9,0 \\
\hline R. A. C. M. & $\mathrm{H}$ & $\bar{M}$ & 8,5 & $\mathrm{G}$ & $\mathrm{F}$ & $E$ & $E$ & $E$ & $\mathrm{G}$ & $E$ & 76,4 & 8,3 \\
\hline O.C.C. & $\mathrm{H}$ & $\bar{M}$ & 8,0 & $\mathrm{G}$ & $\mathrm{F}$ & $\mathrm{E}$ & $\mathrm{E}$ & $E$ & $\mathrm{~F}$ & $\mathrm{D}$ & 73,2 & 8,1 \\
\hline E. A. & $\mathrm{H}$ & $M$ & 8,7 & $\mathrm{~F}$ & $\mathrm{~F}$ & $\mathrm{E}$ & $\mathrm{E}$ & $\mathrm{D}$ & $\mathrm{G}$ & $\mathrm{D}$ & 67,6 & 7,9 \\
\hline T.F.D. & $\mathrm{H}$ & $\mathrm{M}$ & 8,0 & $G$ & $\mathrm{~F}$ & $\mathrm{E}$ & $\mathrm{D}$ & $\mathrm{D}$ & $\mathrm{G}$ & $\mathrm{D}$ & 67,7 & 7,9 \\
\hline B. M. L. & $\bar{H}$ & $\bar{M}$ & 8,1 & $\mathrm{G}$ & $\mathrm{F}$ & $\mathrm{E}$ & $E$ & $\mathrm{D}$ & $\mathrm{G}$ & $\mathrm{D}$ & 71,7 & 8,0 \\
\hline J. A. R. C. M. & $\mathrm{H}$ & $\mathrm{M}$ & 8,0 & $G$ & $G$ & $\mathrm{E}$ & $\mathrm{D}$ & $\mathrm{D}$ & $G$ & $E$ & 74,0 & 8,1 \\
\hline J. A. A. C. & $\mathrm{H}$ & $\mathrm{M}$ & 8,9 & $\mathrm{G}$ & $\mathrm{F}$ & $\mathrm{F}$ & $E$ & $E$ & $\mathrm{G}$ & $\mathrm{D}$ & 76,1 & 8,3 \\
\hline R. F. B. & $\bar{H}$ & $\bar{M}$ & 8,6 & $\mathrm{G}$ & $\mathrm{G}$ & $E$ & $E$ & $\mathrm{D}$ & $\mathrm{G}$ & $E$ & 78,0 & 8,4 \\
\hline F. R. O. & $\mathrm{H}$ & $\mathrm{M}$ & 8,7 & $\mathrm{G}$ & $\mathrm{F}$ & $E$ & $E$ & $\mathrm{D}$ & $\mathrm{G}$ & $E$ & 74,1 & 8,1 \\
\hline M. T. & $\mathrm{H}$ & $\mathrm{M}$ & 8,6 & $G$ & $\mathrm{~F}$ & $\mathrm{E}$ & $\mathrm{E}$ & $\mathrm{D}$ & $G$ & $E$ & 74,1 & 8,1 \\
\hline F. A. D. & $\mathrm{H}$ & $\mathrm{M}$ & 8,7 & $\mathrm{H}$ & $G$ & $\bar{F}$ & $E$ & $E$ & $G$ & $E$ & 86,0 & 9,4 \\
\hline R. R. D. & $\mathrm{H}$ & $\mathrm{M}$ & 8,6 & $G$ & $G$ & $\mathrm{~F}$ & $\mathrm{E}$ & $E$ & $G$ & $\mathrm{D}$ & 80,0 & 8,6 \\
\hline
\end{tabular}


Tabela A-4

\begin{tabular}{|c|c|c|c|c|c|c|c|c|c|c|c|c|c|c|c|c|c|}
\hline Nome & Grupo & Idade & Gênero & 17 & 16 & 15 & 14 & 13 & 12 & 11 & 21 & 22 & 23 & 24 & 25 & 26 & 27 \\
\hline A.P.T. & $\mathrm{V}$ & 5,5 & $\mathrm{~F}$ & - & - & - & - & - & - & - & - & - & - & - & - & - & - \\
\hline J.M.R.M. & $\bar{V}$ & 5,4 & $\mathrm{M}$ & - & - & - & - & - & - & - & - & - & - & - & - & - & - \\
\hline T.S.C. & $\mathrm{V}$ & 5,0 & $M$ & - & - & - & - & - & - & - & - & - & - & - & - & - & - \\
\hline T.V.S. & $\mathrm{V}$ & 5,5 & $\mathrm{M}$ & - & - & - & - & - & - & - & - & - & - & - & - & - & - \\
\hline D.F.D. & $\mathrm{V}$ & 5,6 & $\mathrm{M}$ & - & - & - & - & - & - & - & - & - & - & - & - & - & - \\
\hline R.A.A.P.R. & $\mathrm{V}$ & 5,7 & $\mathrm{~F}$ & - & - & - & - & - & - & - & - & - & - & - & - & - & - \\
\hline A.I.M.B. & $\mathrm{V}$ & 5,0 & $\mathrm{~F}$ & - & - & - & - & - & - & - & - & - & - & - & - & - & - \\
\hline D.A.M. & V & 5,2 & M & - & - & - & - & - & - & - & - & - & - & - & - & - & - \\
\hline G.R.C. & V & 5,0 & $M$ & - & - & - & - & - & - & - & - & - & - & - & - & - & - \\
\hline A.C.M. & V & 5,5 & $\mathrm{~F}$ & - & - & - & - & - & - & - & - & - & - & - & - & - & - \\
\hline E.P.B. & V & 5,7 & $\mathrm{~F}$ & - & - & - & - & - & - & $\mathrm{P}$ & - & - & - & - & - & - & - \\
\hline P.S.P.C. & V & 5,0 & $M$ & - & - & - & - & - & - & - & - & - & - & - & - & - & - \\
\hline E.C.M. & $\mathrm{V}$ & 5,9 & $\mathrm{~F}$ & - & - & - & - & - & - & - & - & - & - & - & - & - & - \\
\hline A.L.M. & $\mathrm{V}$ & 5,1 & $\mathrm{~F}$ & - & - & - & - & - & - & - & - & - & - & - & - & - & - \\
\hline J.C.M.J. & $\mathrm{V}$ & 5,7 & $\bar{M}$ & - & - & - & - & - & - & - & - & - & - & - & - & - & - \\
\hline A.F.G. & $\mathrm{V}$ & 5,6 & $\bar{M}$ & - & $\mathrm{P}$ & - & - & - & - & - & - & - & - & - & - & $\mathrm{P}$ & - \\
\hline P.B.J. & $\mathrm{V}$ & 5,3 & $\mathrm{M}$ & - & - & - & - & - & - & - & - & - & - & - & - & - & - \\
\hline R.G.M. & $\mathrm{V}$ & 5,2 & $\mathrm{M}$ & - & - & - & - & - & - & - & - & - & - & - & - & - & - \\
\hline T.C.C.C. & V & 5,5 & $\mathrm{~F}$ & - & - & - & - & - & - & - & - & - & - & - & - & - & - \\
\hline R.A.S.S. & $\mathrm{V}$ & 5,1 & $F$ & - & - & - & - & - & - & - & - & - & - & - & - & - & - \\
\hline F.B.A. & V & 5,0 & $\mathrm{~F}$ & - & - & - & - & - & - & - & - & - & - & - & - & - & - \\
\hline M.F.G. & V & 5,6 & $F$ & - & - & - & - & - & - & - & - & - & - & - & - & $\mathrm{P}$ & - \\
\hline S.D. & V & 5,9 & $\mathrm{~F}$ & - & - & - & - & - & - & - & - & - & - & - & - & - & - \\
\hline F.B.R. & V & 5,0 & $\mathrm{~F}$ & - & - & - & - & - & - & - & - & - & - & - & - & - & - \\
\hline E.F.Z. & $\mathrm{V}$ & 5,3 & $\mathrm{~F}$ & - & - & - & - & - & - & - & - & - & - & - & - & - & - \\
\hline A.R.F. & $\overline{\mathrm{V}}$ & 5,9 & $\bar{M}$ & - & $P$ & - & - & - & - & - & - & - & - & - & - & $P$ & - \\
\hline M.G.T. & $\mathrm{V}$ & 5,6 & $\bar{M}$ & - & $\mathrm{P}$ & - & - & - & - & - & - & - & - & - & - & $\mathrm{P}$ & - \\
\hline E.L.C.S. & $\mathrm{V}$ & 5,9 & $M$ & - & - & - & - & - & - & - & - & - & - & - & - & - & - \\
\hline H.J.S.S. & V & 5,5 & $\mathrm{M}$ & - & - & - & - & - & - & - & - & - & - & - & - & - & - \\
\hline M.S. & V & 5,1 & $\mathrm{M}$ & - & - & - & - & - & - & - & - & - & - & - & - & - & - \\
\hline E.D.B. & $\mathrm{H}$ & 5,6 & $\mathrm{~F}$ & - & - & - & - & - & - & - & - & - & - & - & - & - & - \\
\hline C.M.T. & $\mathrm{H}$ & 5,9 & $\mathrm{M}$ & - & $\mathrm{P}$ & - & - & - & - & - & - & - & - & - & - & $\mathrm{P}$ & - \\
\hline V.M.A.C. & $\mathrm{H}$ & 5,3 & $\mathrm{~F}$ & - & - & - & - & - & - & $\mathrm{P}$ & - & - & - & - & - & - & - \\
\hline C.C.L.L. & $\mathrm{H}$ & 5,5 & $M$ & - & - & - & - & - & - & - & - & - & - & - & - & - & - \\
\hline R.P.F. & $\overline{\mathrm{H}}$ & 5,8 & $M$ & - & - & - & - & - & - & - & - & - & - & - & - & - & - \\
\hline A.C.D. & $\mathrm{H}$ & 5,1 & $\mathrm{~F}$ & - & - & - & - & - & - & - & - & - & - & - & - & - & - \\
\hline F.B.C. & $\mathrm{H}$ & 5,2 & $\bar{M}$ & - & - & - & - & - & - & - & - & - & - & - & - & - & - \\
\hline C.J.C.F. & $\overline{\mathrm{H}}$ & 5,2 & $M$ & - & - & - & - & - & - & - & - & - & - & - & - & - & - \\
\hline D.F.C. & $\mathrm{H}$ & 5,6 & $\mathrm{~F}$ & - & - & - & - & - & - & - & - & - & - & - & - & - & - \\
\hline E.C.L. & $\mathrm{H}$ & 5,6 & $\mathrm{~F}$ & - & - & - & - & - & - & - & - & - & - & - & - & - & - \\
\hline R.F.E. & $\mathrm{H}$ & 5,2 & $M$ & - & - & - & - & - & - & - & - & - & - & - & - & - & - \\
\hline S.T.G. & $\overline{\mathrm{H}}$ & 5,0 & $\mathrm{M}$ & - & - & - & - & - & - & - & - & - & - & - & - & - & - \\
\hline R.F.B. & $\mathrm{H}$ & 5,8 & $M$ & - & - & - & - & - & - & - & - & - & - & - & - & - & - \\
\hline R.R.D. & $\mathrm{H}$ & 5,6 & $M$ & - & - & - & - & - & - & - & - & - & - & - & - & - & - \\
\hline J.A.R.C.M. & $\mathrm{H}$ & 5,9 & $M$ & - & - & - & - & - & - & - & - & - & - & - & - & - & - \\
\hline R.O.B.A. & $\overline{\mathrm{H}}$ & 5,5 & $\bar{M}$ & - & - & - & - & - & - & - & - & - & - & - & - & - & - \\
\hline C.F.Z.S. & $\mathrm{H}$ & 5,1 & $\mathrm{~F}$ & - & - & - & - & - & - & - & - & - & - & - & - & - & - \\
\hline M.P.P. & $\mathrm{H}$ & 5,3 & $\mathrm{~F}$ & - & - & - & - & - & - & - & - & - & - & - & - & - & - \\
\hline T.F.D. & $\overline{\mathrm{H}}$ & 5,0 & $\bar{M}$ & - & - & - & - & - & - & - & - & - & - & - & - & - & - \\
\hline C.L.C. & $\mathrm{H}$ & 5,2 & $\mathrm{~F}$ & - & - & - & - & - & - & - & - & - & - & - & - & - & - \\
\hline T.S.N.J. & $\mathrm{H}$ & 5,2 & $M$ & - & - & - & - & - & - & - & - & - & - & - & - & - & - \\
\hline O.C.C. & $\overline{\mathrm{H}}$ & 5,6 & $\bar{M}$ & - & - & - & - & - & - & - & - & - & - & - & - & - & - \\
\hline J.A.A.C. & $\mathrm{H}$ & 5,8 & $\bar{M}$ & - & $\mathrm{P}$ & - & - & - & - & - & - & - & - & - & - & $\mathrm{P}$ & \\
\hline F.B. & $\mathrm{H}$ & 5,5 & $\mathrm{~F}$ & - & - & - & - & - & - & - & - & - & - & - & - & - & - \\
\hline C.B.J. & $\mathrm{H}$ & 5,3 & $\mathrm{~F}$ & - & - & - & - & - & - & - & - & - & - & - & - & - & - \\
\hline D.E.H. & $\overline{\mathrm{H}}$ & 5,2 & $F$ & - & - & - & - & - & - & - & - & - & - & - & - & - & - \\
\hline M.L.P. & $\mathrm{H}$ & 5,5 & $\mathrm{~F}$ & - & - & - & - & - & - & - & - & - & - & - & - & - & - \\
\hline L.B. & $\mathrm{H}$ & 5,5 & $\mathrm{~F}$ & - & $\mathrm{P}$ & - & - & - & - & - & - & - & - & - & - & $\mathrm{P}$ & - \\
\hline A.P.M.B. & $\mathrm{H}$ & 5,8 & $\mathrm{~F}$ & - & $\mathrm{P}$ & - & - & - & - & - & - & - & - & - & - & - & - \\
\hline P.S.E. & $\mathrm{H}$ & 5,5 & $\mathrm{~F}$ & - & - & - & - & - & - & - & - & - & - & - & - & - & - \\
\hline
\end{tabular}


Tabela A-5

\begin{tabular}{|c|c|c|c|c|c|c|c|c|c|c|c|c|c|c|c|c|c|}
\hline Nome & Grupo & Idade & Gênero & 37 & 36 & 35 & 34 & 33 & 32 & 31 & 41 & 42 & 43 & 44 & 45 & 46 & 47 \\
\hline A.P.T. & V & 5,5 & $\mathrm{~F}$ & - & - & - & - & - & - & - & - & - & - & - & - & - & - \\
\hline J.M.R.M. & $\mathrm{V}$ & 5,4 & $\mathrm{M}$ & - & - & - & - & - & - & - & - & - & - & - & - & - & - \\
\hline T.S.C. & $\mathrm{V}$ & 5,0 & $\mathrm{M}$ & - & - & - & - & - & - & - & - & - & - & - & - & - & - \\
\hline T.V.S. & $\mathrm{V}$ & 5,5 & $\mathrm{M}$ & - & - & - & - & - & - & - & - & - & - & - & - & - & - \\
\hline D.F.D. & $\mathrm{V}$ & 5,6 & $\mathrm{M}$ & - & - & - & - & - & - & - & - & - & - & - & - & - & - \\
\hline R.A.A.P.R. & $\mathrm{V}$ & 5,7 & $\mathrm{~F}$ & - & - & - & - & - & - & - & - & - & - & - & - & - & - \\
\hline A.I.M.B. & V & 5,0 & $\mathrm{~F}$ & - & - & - & - & - & - & - & - & - & - & - & - & - & - \\
\hline D.A.M. & V & 5,2 & $\mathrm{M}$ & - & - & - & - & - & - & - & - & - & - & - & - & - & - \\
\hline G.R.C. & V & 5,0 & $\mathrm{M}$ & - & - & - & - & - & - & - & - & - & - & - & - & - & - \\
\hline A.C.M. & $\mathrm{V}$ & 5,5 & $\mathrm{~F}$ & - & - & - & - & - & - & - & - & - & - & - & - & - & - \\
\hline E.P.B. & V & 5,7 & $\mathrm{~F}$ & - & - & - & - & - & - & - & $\mathrm{P}$ & - & - & - & - & - & - \\
\hline P.S.P.C. & V & 5,0 & $\mathrm{M}$ & - & - & - & - & - & - & - & - & - & - & - & - & - & - \\
\hline E.C.M. & $\mathrm{V}$ & 5,9 & $\mathrm{~F}$ & - & - & - & - & - & - & - & - & - & - & - & - & - & - \\
\hline A.L.M. & V & 5,1 & $\mathrm{~F}$ & - & - & - & - & - & - & - & - & - & - & - & - & - & - \\
\hline J.C.M.J. & V & 5,7 & $\mathrm{M}$ & - & - & - & - & - & - & - & - & - & - & - & - & - & - \\
\hline A.F.G. & $\mathrm{V}$ & 5,6 & $\mathrm{M}$ & - & $\mathrm{P}$ & - & - & - & - & - & $P$ & - & - & - & - & $P$ & - \\
\hline P.B.J. & V & 5,3 & $\mathrm{M}$ & - & - & - & - & - & - & - & - & - & - & - & - & - & - \\
\hline R.G.M. & V & 5,2 & $\mathrm{M}$ & - & - & - & - & - & - & - & $\mathrm{P}$ & - & - & - & - & - & - \\
\hline T.C.C.C. & V & 5,5 & $\mathrm{~F}$ & - & - & - & - & - & - & - & - & - & - & - & - & - & - \\
\hline R.A.S.S. & $\mathrm{V}$ & 5,1 & $\mathrm{~F}$ & - & - & - & - & - & - & - & - & - & - & - & - & - & - \\
\hline F.B.A. & $\mathrm{V}$ & 5,0 & $\mathrm{~F}$ & - & - & - & - & - & - & - & - & - & - & - & - & - & - \\
\hline M.F.G. & V & 5,6 & $\mathrm{~F}$ & - & - & - & - & - & - & - & - & - & - & - & - & - & - \\
\hline S.D. & $\mathrm{V}$ & 5,9 & $\mathrm{~F}$ & - & - & - & - & - & - & $\mathrm{P}$ & $\mathrm{P}$ & - & - & - & - & - & - \\
\hline F.B.R. & $\mathrm{V}$ & 5,0 & $\mathrm{~F}$ & - & - & - & - & - & - & - & - & - & - & - & - & - & - \\
\hline E.F.Z. & V & 5,3 & $\mathrm{~F}$ & - & - & - & - & - & - & - & - & - & - & - & - & - & - \\
\hline A.R.F. & $\mathrm{V}$ & 5,9 & $\mathrm{M}$ & - & - & - & - & - & - & - & $\mathrm{P}$ & - & - & - & - & - & - \\
\hline M.G.T. & $\mathrm{V}$ & 5,6 & $\bar{M}$ & - & $\mathrm{P}$ & - & - & - & - & $\mathrm{P}$ & $\mathrm{P}$ & - & - & - & - & $\mathrm{P}$ & - \\
\hline E.L.C.S. & V & 5,9 & $\mathrm{M}$ & - & $P$ & - & - & - & - & - & - & - & - & - & - & - & - \\
\hline H.J.S.S. & V & 5,5 & $\mathrm{M}$ & - & - & - & - & - & - & - & - & - & - & - & - & - & - \\
\hline M.S. & V & 5,1 & $\bar{M}$ & - & - & - & - & - & - & - & - & - & - & - & - & - & - \\
\hline E.D.B. & $\mathrm{H}$ & 5,6 & $\mathrm{~F}$ & - & - & - & - & - & - & - & - & - & - & - & - & - & - \\
\hline C.M.T. & $\mathrm{H}$ & 5,9 & $\mathrm{M}$ & - & $\mathrm{P}$ & - & - & - & - & $\mathrm{P}$ & - & - & - & - & - & - & - \\
\hline V.M.A.C. & $\mathrm{H}$ & 5,3 & $\mathrm{~F}$ & - & $\mathrm{P}$ & - & - & - & - & - & - & - & - & - & - & $\mathrm{P}$ & - \\
\hline C.C.L.L. & $\mathrm{H}$ & 5,5 & M & - & - & - & - & - & - & - & - & - & - & - & - & - & - \\
\hline R.P.F. & $\mathrm{H}$ & 5,8 & $\mathrm{M}$ & - & - & - & - & - & - & - & - & - & - & - & - & - & - \\
\hline A.C.D. & $\mathrm{H}$ & 5,1 & $\mathrm{~F}$ & - & - & - & - & - & - & - & - & - & - & - & - & - & - \\
\hline F.B.C. & $\mathrm{H}$ & 5,2 & $\mathrm{M}$ & - & - & - & - & - & - & - & - & - & - & - & - & - & - \\
\hline C.J.C.F. & $\mathrm{H}$ & 5,2 & $\mathrm{M}$ & - & - & - & - & - & - & - & - & - & - & - & - & - & - \\
\hline D.F.C. & $\mathrm{H}$ & 5,6 & $\mathrm{~F}$ & - & - & - & - & - & - & - & - & - & - & - & - & - & - \\
\hline E.C.L. & $\mathrm{H}$ & 5,6 & $\mathrm{~F}$ & - & - & - & - & - & - & - & - & - & - & - & - & - & - \\
\hline R.F.E. & $\mathrm{H}$ & 5,2 & $\mathrm{M}$ & - & - & - & - & - & - & - & - & - & - & - & - & - & - \\
\hline S.T.G. & $\mathrm{H}$ & 5,0 & $\mathrm{M}$ & - & - & - & - & - & - & - & - & - & - & - & - & - & - \\
\hline R.F.B. & $\mathrm{H}$ & 5,8 & $\mathrm{M}$ & - & - & - & - & - & - & - & - & - & - & - & - & - & - \\
\hline R.R.D. & $\mathrm{H}$ & 5,6 & $M$ & - & - & - & - & - & - & - & - & - & - & - & - & - & - \\
\hline J.A.R.C.M. & $\bar{H}$ & 5,9 & $\bar{M}$ & - & - & - & - & - & - & - & - & - & - & - & - & - & - \\
\hline R.O.B.A. & $\mathrm{H}$ & 5,5 & $\mathrm{M}$ & - & - & - & - & - & - & - & - & - & - & - & - & - & - \\
\hline C.F.Z.S. & $\mathrm{H}$ & 5,1 & $\mathrm{~F}$ & - & - & - & - & - & - & - & - & - & - & - & - & - & - \\
\hline M.P.P. & $\mathrm{H}$ & 5,3 & $\mathrm{~F}$ & - & - & - & - & - & - & - & - & - & - & - & - & - & - \\
\hline T.F.D. & $\mathrm{H}$ & 5,0 & $\mathrm{M}$ & - & - & - & - & - & - & - & - & - & - & - & - & - & - \\
\hline C.L.C. & $\mathrm{H}$ & 5,2 & $\mathrm{~F}$ & - & - & - & - & - & - & - & - & - & - & - & - & - & - \\
\hline T.S.N.J. & $\mathrm{H}$ & 5,2 & $M$ & - & - & - & - & - & - & - & - & - & - & - & - & - & - \\
\hline O.C.C. & $\mathrm{H}$ & 5,6 & $\mathrm{M}$ & - & - & - & - & - & - & - & - & - & - & - & - & - & - \\
\hline J.A.A.C. & $\mathrm{H}$ & 5,8 & $\mathrm{M}$ & - & - & - & - & - & - & - & $\mathrm{P}$ & - & - & - & - & - & - \\
\hline F.B. & $\mathrm{H}$ & 5,5 & $\mathrm{~F}$ & - & - & - & - & - & - & - & - & - & - & - & - & - & - \\
\hline C.B.J. & $\mathrm{H}$ & 5,3 & $\mathrm{~F}$ & - & - & - & - & - & - & - & - & - & - & - & - & - & - \\
\hline D.E.H. & $\mathrm{H}$ & 5,2 & $\mathrm{~F}$ & - & - & - & - & - & - & - & - & - & - & - & - & - & - \\
\hline M.L.P. & $\mathrm{H}$ & 5,5 & $\mathrm{~F}$ & - & $P$ & - & - & - & - & - & - & - & - & - & - & $\mathrm{P}$ & - \\
\hline L.B. & $\mathrm{H}$ & 5,5 & $\mathrm{~F}$ & - & $P$ & - & - & - & - & - & - & - & - & - & - & $\mathrm{P}$ & - \\
\hline A.P.M.B. & $\mathrm{H}$ & 5,8 & $\mathrm{~F}$ & - & $P$ & - & - & - & - & $\mathrm{P}$ & $\mathrm{P}$ & - & - & - & - & $P$ & - \\
\hline P.S.E. & $\mathrm{H}$ & 5,5 & $\mathrm{~F}$ & - & - & - & - & - & - & - & - & - & - & - & - & - & - \\
\hline
\end{tabular}


Tabela A-6

\begin{tabular}{|c|c|c|c|c|c|c|c|c|c|c|c|c|c|c|c|c|c|}
\hline Nome & Grupo & Idade & Gênero & 17 & 16 & 15 & 14 & 13 & 12 & 11 & 21 & 22 & 23 & 24 & 25 & 26 & 27 \\
\hline A.P.T. & V & 6,6 & $\mathrm{~F}$ & - & - & - & - & - & - & - & - & - & - & - & - & - & - \\
\hline R.A.A. & $\bar{V}$ & 6,3 & $\mathrm{M}$ & - & $\mathrm{P}$ & - & - & - & - & - & - & - & - & - & - & $P$ & - \\
\hline G.F.P. & $\mathrm{V}$ & 6,0 & $\mathrm{~F}$ & - & $\mathrm{P}$ & - & - & - & - & $\mathrm{P}$ & $\mathrm{P}$ & - & - & - & - & $P$ & - \\
\hline A.I.M.B. & $\mathrm{V}$ & 6,5 & $\mathrm{~F}$ & - & - & - & - & - & - & $\mathrm{P}$ & $\mathrm{P}$ & - & - & - & - & - & - \\
\hline D.A.M. & $\mathrm{V}$ & 6,5 & $\mathrm{M}$ & - & $\mathrm{P}$ & - & - & - & - & $\mathrm{P}$ & - & - & - & - & - & $\mathrm{P}$ & - \\
\hline G.R.C. & $\mathrm{V}$ & 6,1 & $\mathrm{M}$ & - & $\mathrm{P}$ & - & - & - & - & - & - & - & - & - & - & $\mathrm{P}$ & - \\
\hline E.P.B. & V & 6,7 & $\mathrm{~F}$ & - & $\mathrm{P}$ & - & - & - & - & $P$ & $\mathrm{P}$ & - & - & - & - & $P$ & - \\
\hline P.S.P.C. & V & 6,5 & $M$ & - & - & - & - & - & - & - & - & - & - & - & - & - & - \\
\hline E.C.M. & $\mathrm{V}$ & 6,9 & $\mathrm{~F}$ & - & - & - & - & - & - & - & - & - & - & - & - & - & - \\
\hline J.C.M.J. & $\mathrm{V}$ & 6,9 & $M$ & - & - & - & - & - & - & - & - & - & - & - & - & - & - \\
\hline A.F.G. & V & 6,8 & $M$ & - & $\mathrm{P}$ & - & - & - & - & - & - & - & - & - & - & $P$ & - \\
\hline M.A.P.T. & V & 6,0 & $\mathrm{M}$ & - & - & - & - & - & - & - & - & - & - & - & - & - & - \\
\hline P.B.J. & $\mathrm{V}$ & 6,7 & $M$ & - & $\mathrm{P}$ & - & - & - & - & - & - & - & - & - & - & $P$ & - \\
\hline T.C.C.C. & V & 6,6 & $\mathrm{~F}$ & - & $P$ & - & - & - & - & $\mathrm{P}$ & $P$ & - & - & - & - & $P$ & - \\
\hline M.Q.B. & $\mathrm{V}$ & 6,6 & $\mathrm{M}$ & - & $\mathrm{P}$ & - & - & - & - & $P$ & $P$ & - & - & - & - & $P$ & - \\
\hline R.A.S.S. & $\mathrm{V}$ & 6,5 & $F$ & - & - & - & - & - & - & - & - & - & - & - & - & - & - \\
\hline R.B.R. & $\mathrm{V}$ & 6,2 & $F$ & - & $\mathrm{P}$ & - & - & - & - & - & - & - & - & - & - & $P$ & - \\
\hline F.B.A. & $\mathrm{V}$ & 6,4 & $\mathrm{~F}$ & - & $\mathrm{P}$ & - & - & - & - & - & - & - & - & - & - & $P$ & - \\
\hline M.F.G. & $\mathrm{V}$ & 6,5 & $\mathrm{~F}$ & - & $\mathrm{P}$ & - & - & - & - & $\mathrm{P}$ & - & - & - & - & - & $P$ & - \\
\hline S.D. & $\mathrm{V}$ & 6,9 & $\mathrm{~F}$ & - & $\mathrm{P}$ & - & - & - & - & $\mathrm{P}$ & $\mathrm{P}$ & - & - & - & - & $P$ & - \\
\hline F.B.R. & V & 6,0 & $\mathrm{~F}$ & - & - & - & - & - & - & - & - & - & - & - & - & - & - \\
\hline E.F.Z. & $\mathrm{V}$ & 6,5 & $F$ & - & - & - & - & - & - & - & - & - & - & - & - & - & - \\
\hline A.R.F. & $\mathrm{V}$ & 6,9 & $\mathrm{M}$ & - & $\mathrm{P}$ & - & - & - & - & - & $\mathrm{P}$ & - & - & - & - & $P$ & - \\
\hline M.G.T. & V & 6,5 & $M$ & - & $\mathrm{P}$ & - & - & - & - & $\mathrm{P}$ & $\mathrm{P}$ & - & - & - & - & $P$ & - \\
\hline C.V.E. & $\mathrm{V}$ & 6,4 & $\mathrm{~F}$ & - & $P$ & - & - & - & - & $P$ & $\mathrm{P}$ & - & - & - & - & $P$ & - \\
\hline R.T.D.G. & V & 6,9 & $M$ & - & $\mathrm{P}$ & - & - & - & - & - & - & - & - & - & - & $P$ & - \\
\hline G.C.T.N. & $\mathrm{V}$ & 6,0 & $\bar{M}$ & - & - & - & - & - & - & - & - & - & - & - & - & - & - \\
\hline R.Q. & V & 6,8 & $M$ & - & $\mathrm{P}$ & - & - & - & - & - & - & - & - & - & - & $P$ & - \\
\hline E.L.C.S. & $\mathrm{V}$ & 6,9 & $\mathrm{M}$ & - & $\mathrm{P}$ & - & - & - & - & - & - & - & - & - & - & $P$ & - \\
\hline H.J.S.S. & $\mathrm{V}$ & 6,7 & $\mathrm{M}$ & - & $\mathrm{P}$ & - & - & - & - & - & - & - & - & - & - & $P$ & - \\
\hline E.D.B. & $\mathrm{H}$ & 6,9 & $\mathrm{~F}$ & - & $\mathrm{P}$ & - & - & - & - & $\mathrm{P}$ & $\mathrm{P}$ & - & - & - & - & $P$ & - \\
\hline V.M.A.C. & $\mathrm{H}$ & 6,7 & $\mathrm{~F}$ & - & $\mathrm{P}$ & - & - & - & $P$ & $\mathrm{P}$ & $\mathrm{P}$ & $\mathrm{P}$ & - & - & - & $P$ & - \\
\hline R.P.F. & $\mathrm{H}$ & 6,7 & $M$ & - & $P$ & - & - & - & - & - & - & - & - & - & - & $P$ & - \\
\hline A.C.D. & $\mathrm{H}$ & 6,5 & $\mathrm{~F}$ & - & $P$ & - & - & - & - & $\mathrm{P}$ & $\mathrm{P}$ & - & - & - & - & $P$ & - \\
\hline C.J.C.F. & $\mathrm{H}$ & 6,2 & $\bar{M}$ & - & $\mathrm{P}$ & - & - & - & - & $\mathrm{P}$ & - & - & - & - & - & $\mathrm{P}$ & - \\
\hline F.S. & $\mathrm{H}$ & 6,3 & $\mathrm{M}$ & - & - & - & - & - & - & - & $\mathrm{P}$ & - & - & - & - & - & - \\
\hline E.C.L. & $\mathrm{H}$ & 6,7 & $\mathrm{~F}$ & - & - & - & - & - & - & - & - & - & - & - & - & - & - \\
\hline R.F.E. & $\overline{\mathrm{H}}$ & 6,2 & $\bar{M}$ & - & $\mathrm{P}$ & - & - & - & - & - & - & - & - & - & - & - & - \\
\hline S.T.G. & $\overline{\mathrm{H}}$ & 6,4 & $\mathrm{M}$ & - & - & - & - & - & - & $\mathrm{P}$ & $\mathrm{P}$ & - & - & - & - & - & - \\
\hline R.R.D. & $\mathrm{H}$ & 6,5 & $\mathrm{M}$ & - & $\mathrm{P}$ & - & - & - & - & - & - & - & - & - & - & $P$ & - \\
\hline J.A.R.C.M. & $\mathrm{H}$ & 6,9 & $M$ & - & - & - & - & - & - & - & - & - & - & - & - & - & - \\
\hline B.M.L. & $\overline{\mathrm{H}}$ & 6,1 & $\mathrm{M}$ & - & - & - & - & - & - & - & - & - & - & - & - & $P$ & - \\
\hline R.O.B.A. & $\mathrm{H}$ & 6,4 & $M$ & - & - & - & - & - & - & - & - & - & - & - & - & - & - \\
\hline C.F.Z.S. & $\mathrm{H}$ & 6,1 & $\mathrm{~F}$ & - & - & - & - & - & - & - & - & - & - & - & - & - & - \\
\hline M.P.P. & $\overline{\mathrm{H}}$ & 6,5 & $\mathrm{~F}$ & - & - & - & - & - & - & $\mathrm{P}$ & $P$ & - & - & - & - & $P$ & - \\
\hline T.F.D. & $\mathrm{H}$ & 6,2 & $\bar{M}$ & - & $\mathrm{P}$ & - & - & - & - & - & - & - & - & - & - & - & - \\
\hline C.L.C. & $\mathrm{H}$ & 6,4 & $F$ & - & $P$ & - & - & - & - & - & $P$ & - & - & - & - & $P$ & - \\
\hline J.A.A.C. & $\mathrm{H}$ & 6,9 & $M$ & - & $\mathrm{P}$ & - & - & - & - & - & - & - & - & - & - & $P$ & - \\
\hline P.B.B.M. & $\mathrm{H}$ & 6,7 & $\mathrm{~F}$ & - & $\mathrm{P}$ & - & - & - & - & - & - & - & - & - & - & $P$ & - \\
\hline M.H.T. & $\mathrm{H}$ & 6,2 & $\mathrm{~F}$ & - & - & - & - & - & - & - & - & - & - & - & - & - & - \\
\hline F.B. & $\mathrm{H}$ & 6,6 & $\mathrm{~F}$ & - & $\mathrm{P}$ & - & - & - & - & - & $\mathrm{P}$ & - & - & - & - & $P$ & - \\
\hline A.B.S.M. & $\overline{\mathrm{H}}$ & 6,8 & $F$ & - & $\mathrm{P}$ & - & - & - & - & - & - & - & - & - & - & $\mathrm{P}$ & - \\
\hline C.B.J. & $\mathrm{H}$ & 6,5 & $\mathrm{~F}$ & - & $\mathrm{P}$ & - & - & - & - & - & - & - & - & - & - & $\mathrm{P}$ & - \\
\hline D.E.H. & $\mathrm{H}$ & 6,6 & $F$ & - & - & - & - & - & - & - & - & - & - & - & - & $P$ & - \\
\hline D.A.M. & $\mathrm{H}$ & 6,4 & $\mathrm{M}$ & - & - & - & - & - & - & - & - & - & - & - & - & - & - \\
\hline P.S.E. & $\overline{\mathrm{H}}$ & 6,4 & $F$ & - & $\mathrm{P}$ & - & - & - & - & - & - & - & - & - & - & $P$ & - \\
\hline J.R.N. & $\mathrm{H}$ & 6,8 & $\mathrm{M}$ & - & $\mathrm{P}$ & - & - & - & - & - & - & - & - & - & - & $P$ & - \\
\hline E.A. & $\mathrm{H}$ & 6,6 & $M$ & - & $P$ & - & - & - & - & - & - & - & - & - & - & $\mathrm{P}$ & - \\
\hline R.A.C.M. & $\mathrm{H}$ & 6,5 & $\mathrm{M}$ & - & - & - & - & - & - & - & - & - & - & - & - & - & - \\
\hline L.F.S.G. & $\mathrm{H}$ & 6,3 & $M$ & - & - & - & - & - & - & - & - & - & - & - & - & - & - \\
\hline
\end{tabular}


Tabela A-7

\begin{tabular}{|c|c|c|c|c|c|c|c|c|c|c|c|c|c|c|c|c|c|}
\hline Nome & Grupo & Idade & Gênero & 37 & 36 & 35 & 34 & 33 & 32 & 31 & 41 & 42 & 43 & 44 & 45 & 46 & 47 \\
\hline A.P.T. & V & 6,6 & $\mathrm{~F}$ & - & - & - & - & - & - & - & - & - & - & - & - & - & - \\
\hline R.A.A. & $\bar{V}$ & 6,3 & $\mathrm{M}$ & - & $P$ & - & - & - & - & - & $\mathrm{P}$ & $\mathrm{P}$ & - & - & - & $P$ & - \\
\hline G.F.P. & $\mathrm{V}$ & 6,0 & $\mathrm{~F}$ & - & $\mathrm{P}$ & - & - & - & - & $\mathrm{P}$ & $\mathrm{P}$ & - & - & - & - & $P$ & - \\
\hline A.I.M.B. & $\mathrm{V}$ & 6,5 & $\mathrm{~F}$ & - & - & - & - & - & - & $\mathrm{P}$ & $\mathrm{P}$ & - & - & - & - & - & - \\
\hline D.A.M. & $\mathrm{V}$ & 6,5 & $\mathrm{M}$ & - & $\mathrm{P}$ & - & - & - & $\mathrm{P}$ & $\mathrm{P}$ & $\mathrm{P}$ & - & - & - & - & $\mathrm{P}$ & - \\
\hline G.R.C. & $\mathrm{V}$ & 6,1 & $\mathrm{M}$ & - & $\mathrm{P}$ & - & - & - & - & $\mathrm{P}$ & $\mathrm{P}$ & - & - & - & - & $P$ & - \\
\hline E.P.B. & $\mathrm{V}$ & 6,7 & $F$ & - & $\mathrm{P}$ & - & - & - & $P$ & $P$ & $\mathrm{P}$ & $\mathrm{P}$ & - & - & - & $P$ & - \\
\hline P.S.P.C. & V & 6,5 & $M$ & - & - & - & - & - & - & $\mathrm{P}$ & $P$ & - & - & - & - & - & - \\
\hline E.C.M. & $\mathrm{V}$ & 6,9 & $\mathrm{~F}$ & - & $\mathrm{P}$ & - & - & - & - & $\mathrm{P}$ & $P$ & - & - & - & - & $P$ & - \\
\hline J.C.M.J. & $\mathrm{V}$ & 6,9 & $M$ & - & - & - & - & - & - & - & $\mathrm{P}$ & - & - & - & - & - & - \\
\hline A.F.G. & V & 6,8 & $M$ & - & $\mathrm{P}$ & - & - & - & - & $\mathrm{P}$ & $\mathrm{P}$ & - & - & - & - & $P$ & - \\
\hline M.A.P.T. & V & 6,0 & $\mathrm{M}$ & - & $\mathrm{P}$ & - & - & - & - & $P$ & $\mathrm{P}$ & - & - & - & - & $P$ & - \\
\hline P.B.J. & $\mathrm{V}$ & 6,7 & $M$ & - & $\mathrm{P}$ & - & - & - & - & - & - & - & - & - & - & $P$ & - \\
\hline T.C.C.C. & V & 6,6 & $\mathrm{~F}$ & - & $P$ & - & - & - & - & $\mathrm{P}$ & $P$ & - & - & - & - & $P$ & - \\
\hline M.Q.B. & $\mathrm{V}$ & 6,6 & $M$ & - & $\mathrm{P}$ & - & - & - & $\mathrm{P}$ & $\mathrm{P}$ & $\mathrm{P}$ & $\mathrm{P}$ & - & - & - & $P$ & - \\
\hline R.A.S.S. & $\mathrm{V}$ & 6,5 & $\mathrm{~F}$ & - & - & - & - & - & - & - & - & - & - & - & - & - & - \\
\hline R.B.R. & $\mathrm{V}$ & 6,2 & $F$ & - & $\mathrm{P}$ & - & - & - & - & - & - & - & - & - & - & - & - \\
\hline F.B.A. & $\mathrm{V}$ & 6,4 & $\mathrm{~F}$ & - & $\mathrm{P}$ & - & - & - & $\mathrm{P}$ & $\mathrm{P}$ & $\mathrm{P}$ & $\mathrm{P}$ & - & - & - & - & - \\
\hline M.F.G. & V & 6,5 & $\mathrm{~F}$ & - & $P$ & - & - & - & - & $\mathrm{P}$ & $P$ & - & - & - & - & $P$ & - \\
\hline S.D. & $\mathrm{V}$ & 6,9 & $\mathrm{~F}$ & - & $\mathrm{P}$ & - & - & - & $\mathrm{P}$ & $P$ & $\mathrm{P}$ & $P$ & - & - & - & $P$ & - \\
\hline F.B.R. & V & 6,0 & $\mathrm{~F}$ & - & - & - & - & - & - & - & - & - & - & - & - & - & - \\
\hline E.F.Z. & $\mathrm{V}$ & 6,5 & $\mathrm{~F}$ & - & - & - & - & - & - & - & - & - & - & - & - & - & - \\
\hline A.R.F. & $\mathrm{V}$ & 6,9 & $\bar{M}$ & - & $P$ & - & - & - & - & $\mathrm{P}$ & $\mathrm{P}$ & $P$ & - & - & - & $P$ & - \\
\hline M.G.T. & V & 6,5 & $\mathrm{M}$ & - & $\mathrm{P}$ & - & - & - & $\mathrm{P}$ & $\mathrm{P}$ & $\mathrm{P}$ & $\mathrm{P}$ & - & - & - & $P$ & - \\
\hline C.V.E. & $\mathrm{V}$ & 6,4 & $\mathrm{~F}$ & - & $\mathrm{P}$ & - & - & - & $\mathrm{P}$ & $\mathrm{P}$ & $\mathrm{P}$ & $\mathrm{P}$ & - & - & - & $P$ & - \\
\hline R.T.D.G. & $\mathrm{V}$ & 6,9 & $\bar{M}$ & - & $\mathrm{P}$ & - & - & - & - & $\mathrm{P}$ & $\mathrm{P}$ & - & - & - & - & $\mathrm{P}$ & - \\
\hline G.C.T.N. & $\mathrm{V}$ & 6,0 & $\bar{M}$ & - & - & - & - & - & - & $\mathrm{P}$ & $P$ & - & - & - & - & - & - \\
\hline R.Q. & V & 6,8 & $\mathrm{M}$ & - & $\mathrm{P}$ & - & - & - & - & $\mathrm{P}$ & - & - & - & - & - & $P$ & - \\
\hline E.L.C.S. & $\mathrm{V}$ & 6,9 & $\mathrm{M}$ & - & $\mathrm{P}$ & - & - & - & $\mathrm{P}$ & $\mathrm{P}$ & $\mathrm{P}$ & $\mathrm{P}$ & - & - & - & $P$ & - \\
\hline H.J.S.S. & $\mathrm{V}$ & 6,7 & $\mathrm{M}$ & - & $\mathrm{P}$ & - & - & - & - & $\mathrm{P}$ & $\mathrm{P}$ & - & - & - & - & $\mathrm{P}$ & - \\
\hline E.D.B. & $\mathrm{H}$ & 6,9 & $\mathrm{~F}$ & - & $\mathrm{P}$ & - & - & - & - & $\mathrm{P}$ & $\mathrm{P}$ & - & - & - & - & $P$ & - \\
\hline V.M.A.C. & $\mathrm{H}$ & 6,7 & $F$ & - & $\mathrm{P}$ & - & - & - & $P$ & $\mathrm{P}$ & $\mathrm{P}$ & $\mathrm{P}$ & - & - & - & $\mathrm{P}$ & - \\
\hline R.P.F. & $\mathrm{H}$ & 6,7 & $\bar{M}$ & - & $P$ & - & - & - & - & $\mathrm{P}$ & $P$ & - & - & - & - & $P$ & - \\
\hline A.C.D. & $\mathrm{H}$ & 6,5 & $F$ & - & $P$ & - & - & - & $P$ & $P$ & $P$ & $P$ & - & - & - & $P$ & - \\
\hline C.J.C.F. & $\mathrm{H}$ & 6,2 & $\bar{M}$ & - & $\mathrm{P}$ & - & - & - & - & $\mathrm{P}$ & $\mathrm{P}$ & - & - & - & - & $\mathrm{P}$ & - \\
\hline F.S. & $\mathrm{H}$ & 6,3 & $\mathrm{M}$ & - & - & - & - & - & - & - & - & - & - & - & - & - & - \\
\hline E.C.L. & $\overline{\mathrm{H}}$ & 6,7 & $\mathrm{~F}$ & - & $\mathrm{P}$ & - & - & - & - & - & - & - & - & - & - & $P$ & - \\
\hline R.F.E. & $\overline{\mathrm{H}}$ & 6,2 & $\bar{M}$ & - & $\mathrm{P}$ & - & - & - & - & - & - & - & - & - & - & $P$ & - \\
\hline S.T.G. & $\overline{\mathrm{H}}$ & 6,4 & $\mathrm{M}$ & - & - & - & - & - & - & $\mathrm{P}$ & $\mathrm{P}$ & - & - & - & - & - & - \\
\hline R.R.D. & $\mathrm{H}$ & 6,5 & $\bar{M}$ & - & - & - & - & - & - & $\mathrm{P}$ & $\mathrm{P}$ & - & - & - & - & $P$ & - \\
\hline J.A.R.C.M. & $\mathrm{H}$ & 6,9 & $M$ & - & $\mathrm{P}$ & - & - & - & - & $\mathrm{P}$ & $\mathrm{P}$ & - & - & - & - & $P$ & - \\
\hline B.M.L. & $\overline{\mathrm{H}}$ & 6,1 & $\mathrm{M}$ & - & $P$ & - & - & - & - & - & - & - & - & - & - & $P$ & - \\
\hline R.O.B.A. & $\mathrm{H}$ & 6,4 & $\mathrm{M}$ & - & - & - & - & - & - & - & $\mathrm{P}$ & - & - & - & - & - & - \\
\hline C.F.Z.S. & $\mathrm{H}$ & 6,1 & $\mathrm{~F}$ & - & - & - & - & - & - & $\mathrm{P}$ & $\mathrm{P}$ & - & - & - & - & - & - \\
\hline M.P.P. & $\mathrm{H}$ & 6,5 & $F$ & - & $P$ & - & - & - & - & $\mathrm{P}$ & $P$ & - & - & - & - & $\mathrm{P}$ & - \\
\hline T.F.D. & $\mathrm{H}$ & 6,2 & $\bar{M}$ & - & $\mathrm{P}$ & - & - & - & - & $\mathrm{P}$ & $\mathrm{P}$ & - & - & - & - & $\mathrm{P}$ & - \\
\hline C.L.C. & $\mathrm{H}$ & 6,4 & $F$ & - & $P$ & - & - & - & - & $\mathrm{P}$ & $P$ & $P$ & - & - & - & $P$ & - \\
\hline J.A.A.C. & $\mathrm{H}$ & 6,9 & $M$ & - & $\mathrm{P}$ & - & - & - & $\mathrm{P}$ & $\mathrm{P}$ & $\mathrm{P}$ & - & - & - & - & $\mathrm{P}$ & - \\
\hline P.B.B.M. & $\mathrm{H}$ & 6,7 & $\mathrm{~F}$ & - & $\mathrm{P}$ & - & - & - & $P$ & $\mathrm{P}$ & $\mathrm{P}$ & $\mathrm{P}$ & - & - & - & $P$ & - \\
\hline M.H.T. & $\mathrm{H}$ & 6,2 & $\mathrm{~F}$ & - & - & - & - & - & - & - & - & - & - & - & - & - & - \\
\hline F.B. & $\mathrm{H}$ & 6,6 & $F$ & - & $\mathrm{P}$ & - & - & - & - & $\mathrm{P}$ & $\mathrm{P}$ & - & - & - & - & $P$ & - \\
\hline A.B.S.M. & $\mathrm{H}$ & 6,8 & $F$ & - & $\mathrm{P}$ & - & - & - & - & - & $\mathrm{P}$ & - & - & - & - & $\mathrm{P}$ & - \\
\hline C.B.J. & $\mathrm{H}$ & 6,5 & $F$ & - & $\mathrm{P}$ & - & - & - & $\mathrm{P}$ & $\mathrm{P}$ & $\mathrm{P}$ & - & - & - & - & $\mathrm{P}$ & - \\
\hline D.E.H. & $\bar{H}$ & 6,6 & $\mathrm{~F}$ & - & $P$ & - & - & - & - & $\mathrm{P}$ & $P$ & - & - & - & - & $P$ & - \\
\hline D.A.M. & $\mathrm{H}$ & 6,4 & $\mathrm{M}$ & - & - & - & - & - & - & - & - & - & - & - & - & - & - \\
\hline P.S.E. & $\mathrm{H}$ & 6,4 & $F$ & - & $P$ & - & - & - & - & - & - & - & - & - & - & - & - \\
\hline J.R.N. & $\mathrm{H}$ & 6,8 & $\mathrm{M}$ & - & - & - & - & - & - & $\mathrm{P}$ & $\mathrm{P}$ & - & - & - & - & - & - \\
\hline E.A. & $\mathrm{H}$ & 6,6 & $M$ & - & - & - & - & - & - & - & - & - & - & - & - & - & - \\
\hline R.A.C.M. & $\mathrm{H}$ & 6,5 & $\mathrm{M}$ & - & - & - & - & - & - & $\mathrm{P}$ & $\mathrm{P}$ & - & - & - & - & - & - \\
\hline L.F.S.G. & $\mathrm{H}$ & 6,3 & $M$ & - & - & - & - & - & - & $\mathrm{P}$ & $P$ & $P$ & - & - & - & - & - \\
\hline
\end{tabular}


Tabela A-8

\begin{tabular}{|c|c|c|c|c|c|c|c|c|c|c|c|c|c|c|c|c|c|}
\hline Nome & Grupo & Idade & Gênero & 17 & 16 & 15 & 14 & 13 & 12 & 11 & 21 & 22 & 23 & 24 & 25 & 26 & 27 \\
\hline A.P.T. & $\mathrm{V}$ & 7,7 & $\mathrm{~F}$ & - & $\mathrm{P}$ & - & - & - & $\mathrm{P}$ & $\mathrm{P}$ & $\mathrm{P}$ & $\mathrm{P}$ & - & - & - & $\mathrm{P}$ & - \\
\hline J.M.R.M. & $\mathrm{V}$ & 7,9 & $\mathrm{M}$ & - & $P$ & - & - & - & - & $\mathrm{P}$ & $\mathrm{P}$ & - & - & - & - & $\mathrm{P}$ & - \\
\hline T.S.C. & $\mathrm{V}$ & 7,3 & $\mathrm{M}$ & - & $\mathrm{P}$ & - & - & - & - & - & - & - & - & - & - & $\mathrm{P}$ & - \\
\hline T.V.S. & $\mathrm{V}$ & 7,0 & $M$ & - & $P$ & - & - & - & - & - & - & - & - & - & - & $P$ & - \\
\hline R.A.A. & $\mathrm{V}$ & 7,7 & $\mathrm{M}$ & - & $P$ & - & - & - & - & $\mathrm{P}$ & $\mathrm{P}$ & - & - & - & - & $\mathrm{P}$ & - \\
\hline D.F.D. & $\mathrm{V}$ & 7,0 & $\mathrm{M}$ & - & $P$ & - & - & - & - & $\mathrm{P}$ & $\mathrm{P}$ & - & - & - & - & $\mathrm{P}$ & - \\
\hline G.F.P. & $\mathrm{V}$ & 7,1 & $\mathrm{~F}$ & - & $\mathrm{P}$ & - & - & - & - & $\mathrm{P}$ & $\mathrm{P}$ & - & - & - & - & $\mathrm{P}$ & - \\
\hline D.A.M. & $\mathrm{V}$ & 7,5 & $\mathrm{M}$ & - & $P$ & - & - & - & $P$ & $\mathrm{P}$ & $\mathrm{P}$ & $P$ & - & $P$ & - & $\mathrm{P}$ & - \\
\hline G.R.C. & $\mathrm{V}$ & 7,2 & $\mathrm{M}$ & - & $\mathrm{P}$ & - & - & - & - & $\mathrm{P}$ & $\mathrm{P}$ & - & - & - & - & $\mathrm{P}$ & - \\
\hline A.C.M. & $\mathrm{V}$ & 7,5 & $\mathrm{~F}$ & - & $\mathrm{P}$ & - & - & - & - & $\mathrm{P}$ & $\mathrm{P}$ & - & - & - & - & $\mathrm{P}$ & - \\
\hline E.P.B. & $\mathrm{V}$ & 7,8 & $\mathrm{~F}$ & - & $P$ & $P$ & - & - & $P$ & $P$ & $P$ & $P$ & - & - & - & $\mathrm{P}$ & - \\
\hline P.S.P.C. & $\mathrm{V}$ & 7,5 & $\mathrm{M}$ & - & $\mathrm{P}$ & - & - & - & - & $\mathrm{P}$ & $\mathrm{P}$ & - & - & - & - & $\mathrm{P}$ & - \\
\hline E.C.M. & $\mathrm{V}$ & 7,8 & $\mathrm{~F}$ & - & $\mathrm{P}$ & - & - & - & - & $\mathrm{P}$ & - & - & - & - & - & $\mathrm{P}$ & - \\
\hline A.L.M. & $\mathrm{V}$ & 7,2 & $\mathrm{~F}$ & - & $P$ & - & - & - & - & $P$ & $\mathrm{P}$ & - & - & - & - & $P$ & - \\
\hline A.F.G. & $\mathrm{V}$ & 7,6 & $\mathrm{M}$ & - & $P$ & - & - & - & $P$ & $P$ & $P$ & $P$ & - & - & - & $P$ & - \\
\hline P.B.J. & $\mathrm{V}$ & 7,8 & $\mathrm{M}$ & - & $P$ & - & - & - & - & $\mathrm{P}$ & $\mathrm{P}$ & - & - & - & - & $\mathrm{P}$ & - \\
\hline R.G.M. & $\mathrm{V}$ & 7,1 & $\mathrm{M}$ & - & $\mathrm{P}$ & - & - & - & - & $\mathrm{P}$ & $\mathrm{P}$ & $\mathrm{P}$ & - & - & - & $\mathrm{P}$ & - \\
\hline T.C.C.C. & $\mathrm{V}$ & 7,5 & $\mathrm{~F}$ & - & $P$ & - & - & - & $P$ & $\mathrm{P}$ & $P$ & $P$ & - & - & - & $\mathrm{P}$ & - \\
\hline M.Q.B. & $\mathrm{V}$ & 7,5 & $\mathrm{M}$ & - & $\mathrm{P}$ & - & - & - & $P$ & $\mathrm{P}$ & $\mathrm{P}$ & $P$ & - & $P$ & - & $\mathrm{P}$ & - \\
\hline R.B.R. & $\mathrm{V}$ & 7,3 & $\mathrm{~F}$ & - & $\mathrm{P}$ & - & - & - & - & - & - & - & - & - & - & $\mathrm{P}$ & - \\
\hline F.B.A. & $\mathrm{V}$ & $\frac{1,0}{7,3}$ & $\mathrm{~F}$ & - & $P$ & - & - & - & - & $\mathrm{P}$ & $\mathrm{P}$ & - & - & - & - & $P$ & - \\
\hline S.D. & $\mathrm{V}$ & 7,8 & $\mathrm{~F}$ & - & $P$ & - & - & - & $P$ & $\mathrm{P}$ & $\mathrm{P}$ & $P$ & - & - & - & $\mathrm{P}$ & - \\
\hline F.B.R. & $\mathrm{V}$ & 7,0 & $\mathrm{~F}$ & - & $\mathrm{P}$ & - & - & - & - & - & - & - & - & - & - & $\mathrm{P}$ & - \\
\hline E.F.Z. & $\mathrm{V}$ & 7,7 & $\mathrm{~F}$ & - & $P$ & - & - & - & $P$ & $P$ & $P$ & $P$ & - & - & - & $\mathrm{P}$ & - \\
\hline A.R.F. & $\mathrm{V}$ & 7,8 & $\mathrm{M}$ & - & $\mathrm{P}$ & - & - & - & $P$ & $\mathrm{P}$ & $\mathrm{P}$ & - & - & - & - & $\mathrm{P}$ & - \\
\hline M.G.T. & V & 7,6 & $\mathrm{M}$ & - & $\mathrm{P}$ & - & - & - & $P$ & $\mathrm{P}$ & $\mathrm{P}$ & $P$ & - & $P$ & - & $\mathrm{P}$ & - \\
\hline C.V.E. & $\mathrm{V}$ & 7,4 & $\mathrm{~F}$ & - & $\mathrm{P}$ & - & - & - & - & $\mathrm{P}$ & $\mathrm{P}$ & $\mathrm{P}$ & - & - & - & $\mathrm{P}$ & - \\
\hline R.T.D.G. & $\mathrm{V}$ & 7,7 & $\mathrm{M}$ & - & $P$ & - & - & - & - & $P$ & $P$ & - & - & - & - & $P$ & - \\
\hline G.C.T.N. & $\mathrm{V}$ & 7,0 & $\mathrm{M}$ & - & $P$ & - & - & - & - & $\mathrm{P}$ & $\mathrm{P}$ & - & - & - & - & $\mathrm{P}$ & - \\
\hline R.Q. & $\mathrm{V}$ & 7,8 & $\mathrm{M}$ & - & $\mathrm{P}$ & - & - & - & - & - & - & - & - & - & - & $\mathrm{P}$ & - \\
\hline E.D.B. & $\mathrm{H}$ & 7,9 & $\mathrm{~F}$ & - & $P$ & - & - & - & $P$ & $\mathrm{P}$ & $\mathrm{P}$ & $P$ & - & - & - & $\mathrm{P}$ & - \\
\hline V.M.A.C. & $\mathrm{H}$ & 7,8 & $\mathrm{~F}$ & - & $\mathrm{P}$ & - & $\mathrm{P}$ & - & $P$ & $\mathrm{P}$ & $\mathrm{P}$ & $\mathrm{P}$ & - & $P$ & - & $\mathrm{P}$ & - \\
\hline C.C.L.L. & $\mathrm{H}$ & 7.3 & $M$ & - & $\mathrm{P}$ & - & - & - & - & - & - & - & - & - & - & $\mathrm{P}$ & - \\
\hline R.P.F. & $\mathrm{H}$ & 7,7 & $M$ & - & $\mathrm{P}$ & - & - & - & - & $\mathrm{P}$ & $\mathrm{P}$ & - & - & - & - & $\mathrm{P}$ & - \\
\hline A.C.D. & $\mathrm{H}$ & 7,5 & $\mathrm{~F}$ & - & $\mathrm{P}$ & - & - & - & $P$ & $\mathrm{P}$ & $P$ & $\mathrm{P}$ & - & - & - & $\mathrm{P}$ & - \\
\hline F.B.C. & $\mathrm{H}$ & 7,3 & $\mathrm{M}$ & - & $P$ & - & - & - & $P$ & $\mathrm{P}$ & $\mathrm{P}$ & $P$ & - & - & - & $P$ & - \\
\hline C.J.C.F. & $\mathrm{H}$ & 7,2 & $M$ & - & $\mathrm{P}$ & - & - & - & $P$ & $\mathrm{P}$ & $\mathrm{P}$ & $P$ & - & - & - & $\mathrm{P}$ & - \\
\hline D.F.C. & $\mathrm{H}$ & 7,0 & $\mathrm{~F}$ & - & $\mathrm{P}$ & - & - & - & - & - & - & - & - & - & - & $\mathrm{P}$ & - \\
\hline E.C.L. & $\mathrm{H}$ & 7,6 & $\mathrm{~F}$ & - & $\mathrm{P}$ & - & - & - & - & $\mathrm{P}$ & $\mathrm{P}$ & - & - & - & - & $\mathrm{P}$ & - \\
\hline R.F.E. & $\mathrm{H}$ & 7,1 & $\bar{M}$ & - & $\mathrm{P}$ & - & - & - & - & - & - & - & - & - & - & $\mathrm{P}$ & - \\
\hline S.T.G. & $\mathrm{H}$ & 7,4 & $M$ & - & $P$ & - & - & - & - & $\mathrm{P}$ & $\mathrm{P}$ & - & - & - & - & $P$ & - \\
\hline R.F.B. & $\mathrm{H}$ & 7,7 & $\mathrm{M}$ & - & $P$ & - & - & - & - & $\mathrm{P}$ & $\mathrm{P}$ & - & - & - & - & $\mathrm{P}$ & - \\
\hline R.R.D. & $\mathrm{H}$ & 7,6 & $M$ & - & $\mathrm{P}$ & - & - & - & - & $P$ & $P$ & - & - & - & - & $P$ & - \\
\hline J.A.R.C.M. & $\mathrm{H}$ & 7,9 & $M$ & - & $P$ & - & - & - & - & - & $\mathrm{P}$ & - & - & - & - & $\mathrm{P}$ & - \\
\hline B.M.L. & $\mathrm{H}$ & 7,3 & $\bar{M}$ & - & $\mathrm{P}$ & - & - & - & - & $P$ & $P$ & - & - & - & - & $P$ & - \\
\hline R.O.B.A. & $\mathrm{H}$ & 7,5 & $\mathrm{M}$ & - & $P$ & - & - & - & - & - & - & - & - & - & - & $\mathrm{P}$ & - \\
\hline M.P.P. & $\mathrm{H}$ & 7,6 & $\mathrm{~F}$ & - & $\mathrm{P}$ & - & - & - & $P$ & $\mathrm{P}$ & $\mathrm{P}$ & - & - & - & - & $P$ & - \\
\hline T.F.D. & $\mathrm{H}$ & 7,0 & $M$ & - & $P$ & - & - & - & - & $P$ & $P$ & - & - & - & - & $P$ & - \\
\hline C.L.C. & $\mathrm{H}$ & 7,1 & $\mathrm{~F}$ & - & $\mathrm{P}$ & $P$ & - & - & - & $P$ & $P$ & $P$ & - & - & - & $P$ & - \\
\hline T.S.N.J. & $\mathrm{H}$ & 7,8 & $\mathrm{M}$ & - & $\mathrm{P}$ & - & - & - & - & $\mathrm{P}$ & $\mathrm{P}$ & - & - & - & - & $\mathrm{P}$ & - \\
\hline O.C.C. & $\mathrm{H}$ & 7,2 & $\mathrm{M}$ & - & $P$ & - & - & - & - & $P$ & $P$ & - & - & - & - & $P$ & - \\
\hline P.B.B.M. & $\mathrm{H}$ & 7,8 & $\mathrm{~F}$ & - & $P$ & - & - & - & $P$ & $\mathrm{P}$ & $\mathrm{P}$ & - & - & - & - & $\mathrm{P}$ & - \\
\hline M.H.T. & $\mathrm{H}$ & 7,0 & $\mathrm{~F}$ & - & $\mathrm{P}$ & - & - & - & - & - & - & - & - & - & - & $\mathrm{P}$ & - \\
\hline F.B. & $\mathrm{H}$ & 7,5 & $\mathrm{~F}$ & - & $P$ & - & - & - & - & $\mathrm{P}$ & $P$ & $\mathrm{P}$ & - & - & - & $P$ & - \\
\hline A.B.S.M. & $\mathrm{H}$ & 7,9 & $\mathrm{~F}$ & - & $P$ & - & - & - & - & $\mathrm{P}$ & $\mathrm{P}$ & - & - & - & - & $\mathrm{P}$ & - \\
\hline C.B.J. & $\mathrm{H}$ & 7,5 & $\mathrm{~F}$ & - & $P$ & - & - & - & - & $\mathrm{P}$ & $\mathrm{P}$ & - & - & - & - & $\mathrm{P}$ & - \\
\hline D.A.M. & $\mathrm{H}$ & 7,5 & $M$ & - & $\mathrm{P}$ & - & - & - & - & - & - & - & - & - & - & $\mathrm{P}$ & - \\
\hline M.L.P. & $\mathrm{H}$ & 7,0 & $\mathrm{~F}$ & - & $P$ & - & - & - & - & $\mathrm{P}$ & $\mathrm{P}$ & - & - & - & - & $\mathrm{P}$ & - \\
\hline L.B. & $\mathrm{H}$ & 7,6 & $\mathrm{~F}$ & - & $\mathrm{P}$ & - & - & - & $\mathrm{P}$ & $\mathrm{P}$ & $\mathrm{P}$ & $P$ & - & - & - & $\mathrm{P}$ & - \\
\hline A.P.M.B. & $\mathrm{H}$ & 7,0 & $\mathrm{~F}$ & - & $\mathrm{P}$ & - & - & - & - & $\mathrm{P}$ & $\mathrm{P}$ & - & - & - & - & $\mathrm{P}$ & - \\
\hline
\end{tabular}


Tabela A-9

\begin{tabular}{|c|c|c|c|c|c|c|c|c|c|c|c|c|c|c|c|c|c|}
\hline Nome & Grupo & Idade & Gênero & 37 & 36 & 35 & 34 & 33 & 32 & 31 & 41 & 42 & 43 & 44 & 45 & 46 & 47 \\
\hline A.P.T. & V & 7,7 & $\mathrm{~F}$ & - & - & - & - & - & $\mathrm{P}$ & $\mathrm{P}$ & $\mathrm{P}$ & $P$ & - & - & - & $\mathrm{P}$ & - \\
\hline J.M.R.M. & $\mathrm{V}$ & 7,9 & $\mathrm{M}$ & - & $\mathrm{P}$ & - & - & - & $\mathrm{P}$ & $P$ & $P$ & $P$ & - & - & - & $P$ & - \\
\hline T.S.C. & $\mathrm{V}$ & 7,3 & $M$ & - & $\mathrm{P}$ & - & - & - & - & $\mathrm{P}$ & $\mathrm{P}$ & - & - & - & - & $\mathrm{P}$ & - \\
\hline T.V.S. & $\mathrm{V}$ & 7,0 & $\mathrm{M}$ & - & $\mathrm{P}$ & - & - & - & - & $\mathrm{P}$ & $\mathrm{P}$ & - & - & - & - & $\mathrm{P}$ & - \\
\hline R.A.A. & $\mathrm{V}$ & 7,7 & $\mathrm{M}$ & - & $\mathrm{P}$ & - & - & - & $\mathrm{P}$ & $\mathrm{P}$ & $\mathrm{P}$ & - & - & - & - & $\mathrm{P}$ & - \\
\hline D.F.D. & $\mathrm{V}$ & 7,0 & $\bar{M}$ & - & $\mathrm{P}$ & - & - & - & - & $\mathrm{P}$ & $\mathrm{P}$ & - & - & - & - & $\mathrm{P}$ & - \\
\hline G.F.P. & $\mathrm{V}$ & 7,1 & $\mathrm{~F}$ & - & $P$ & - & - & - & $\mathrm{P}$ & $\mathrm{P}$ & $\mathrm{P}$ & $P$ & - & - & - & $\mathrm{P}$ & - \\
\hline D.A.M. & V & 7,5 & M & - & $\mathrm{P}$ & - & - & - & $\mathrm{P}$ & $\mathrm{P}$ & $\mathrm{P}$ & $P$ & - & - & - & $\mathrm{P}$ & - \\
\hline G.R.C. & $\mathrm{V}$ & 7,2 & $\bar{M}$ & - & $\mathrm{P}$ & - & - & - & $P$ & $P$ & $P$ & $P$ & - & - & - & $P$ & - \\
\hline A.C.M. & $\mathrm{V}$ & 7,5 & $\mathrm{~F}$ & - & $\mathrm{P}$ & - & - & - & $\mathrm{P}$ & $\mathrm{P}$ & $\mathrm{P}$ & $P$ & - & - & - & $\mathrm{P}$ & - \\
\hline E.P.B. & V & 7,8 & $\mathrm{~F}$ & - & $\mathrm{P}$ & - & - & - & $P$ & $\mathrm{P}$ & $P$ & $P$ & - & - & - & $\mathrm{P}$ & - \\
\hline P.S.P.C. & V & 7,5 & $\mathrm{M}$ & - & $\mathrm{P}$ & - & - & - & $\mathrm{P}$ & $\mathrm{P}$ & $P$ & $P$ & - & - & - & $\mathrm{P}$ & - \\
\hline E.C.M. & $\mathrm{V}$ & 7,8 & $\mathrm{~F}$ & - & $\mathrm{P}$ & - & - & - & $\mathrm{P}$ & $\mathrm{P}$ & $\mathrm{P}$ & - & - & - & - & $\mathrm{P}$ & - \\
\hline A.L.M. & V & 7,2 & $\mathrm{~F}$ & - & $P$ & - & - & - & $P$ & $P$ & $P$ & $P$ & - & - & - & $P$ & - \\
\hline A.F.G. & $\mathrm{V}$ & 7,6 & $\mathrm{M}$ & - & $P$ & - & - & - & $P$ & $P$ & $P$ & $P$ & - & - & - & $P$ & - \\
\hline P.B.J. & $\mathrm{V}$ & 7,8 & $\mathrm{M}$ & - & $P$ & - & - & - & $\mathrm{P}$ & $\mathrm{P}$ & $\mathrm{P}$ & $P$ & - & - & - & $\mathrm{P}$ & - \\
\hline R.G.M. & $\mathrm{V}$ & 7,1 & $\mathrm{M}$ & - & $P$ & - & - & - & $\mathrm{P}$ & $\mathrm{P}$ & $\mathrm{P}$ & $P$ & - & - & - & $\mathrm{P}$ & - \\
\hline T.C.C.C. & $\mathrm{V}$ & 7,5 & $\mathrm{~F}$ & - & $P$ & - & - & - & $P$ & $P$ & $P$ & $P$ & - & - & - & $P$ & - \\
\hline M.Q.B. & V & 7,5 & $\mathrm{M}$ & - & $\mathrm{P}$ & - & - & - & $\mathrm{P}$ & $\mathrm{P}$ & $\mathrm{P}$ & $P$ & - & - & - & $\mathrm{P}$ & - \\
\hline R.B.R. & $\mathrm{V}$ & 7,3 & $\mathrm{~F}$ & - & $P$ & - & - & - & - & $\mathrm{P}$ & $\mathrm{P}$ & - & - & - & - & $\mathrm{P}$ & - \\
\hline F.B.A. & $\mathrm{V}$ & 7,3 & $\mathrm{~F}$ & - & $\mathrm{P}$ & - & - & - & $\mathrm{P}$ & $\mathrm{P}$ & $\mathrm{P}$ & $P$ & - & - & - & $\mathrm{P}$ & - \\
\hline S.D. & $\mathrm{V}$ & 7,8 & $F$ & - & $\mathrm{P}$ & - & - & - & $\mathrm{P}$ & $\mathrm{P}$ & $\mathrm{P}$ & $P$ & - & - & - & $\mathrm{P}$ & - \\
\hline F.B.R. & V & 7,0 & $\mathrm{~F}$ & - & $\mathrm{P}$ & - & - & - & - & $\mathrm{P}$ & $\mathrm{P}$ & - & - & - & - & $\mathrm{P}$ & - \\
\hline E.F.Z. & $\mathrm{V}$ & 7,7 & $\mathrm{~F}$ & - & $\mathrm{P}$ & - & - & - & $\mathrm{P}$ & $\mathrm{P}$ & $P$ & $P$ & - & - & - & $P$ & - \\
\hline A.R.F. & $\mathrm{V}$ & 7,8 & $\mathrm{M}$ & - & $P$ & - & - & - & $P$ & $\mathrm{P}$ & $\mathrm{P}$ & $P$ & - & - & - & $P$ & - \\
\hline M.G.T. & $\mathrm{V}$ & 7,6 & $M$ & - & $\mathrm{P}$ & - & - & - & $\mathrm{P}$ & $\mathrm{P}$ & $\mathrm{P}$ & $P$ & - & $\mathrm{P}$ & - & $\mathrm{P}$ & - \\
\hline C.V.E. & $\mathrm{V}$ & 7,4 & $\mathrm{~F}$ & - & $\mathrm{P}$ & - & - & - & $\mathrm{P}$ & $\mathrm{P}$ & $\mathrm{P}$ & $P$ & - & - & - & $\mathrm{P}$ & - \\
\hline R.T.D.G. & $\mathrm{V}$ & 7,7 & $M$ & - & $\mathrm{P}$ & - & - & - & $\mathrm{P}$ & $\mathrm{P}$ & $\mathrm{P}$ & $P$ & - & - & - & $\mathrm{P}$ & - \\
\hline G.C.T.N. & $\mathrm{V}$ & 7,0 & $\bar{M}$ & - & $\mathrm{P}$ & - & - & - & - & $\mathrm{P}$ & $\mathrm{P}$ & $P$ & - & - & - & $\mathrm{P}$ & - \\
\hline R.Q. & V & 7,8 & $\mathrm{M}$ & - & $\mathrm{P}$ & - & - & - & - & $\mathrm{P}$ & $\mathrm{P}$ & - & - & - & - & $\mathrm{P}$ & - \\
\hline E.D.B. & $\mathrm{H}$ & 7,9 & $\mathrm{~F}$ & - & $\mathrm{P}$ & - & - & - & $\mathrm{P}$ & $\mathrm{P}$ & $\mathrm{P}$ & $P$ & - & - & - & $\mathrm{P}$ & - \\
\hline V.M.A.C. & $\mathrm{H}$ & 7,8 & $F$ & - & $\mathrm{P}$ & - & - & - & $\mathrm{P}$ & $\mathrm{P}$ & $\mathrm{P}$ & $P$ & - & - & - & $\mathrm{P}$ & - \\
\hline C.C.L.L. & $\bar{H}$ & 7,3 & $\bar{M}$ & - & $\mathrm{P}$ & - & - & - & - & $P$ & $\mathrm{P}$ & - & - & - & - & $P$ & - \\
\hline R.P.F. & $\bar{H}$ & 7,7 & $M$ & - & $P$ & - & - & - & - & $P$ & $P$ & - & - & - & - & $P$ & - \\
\hline A.C.D. & $\bar{H}$ & 7,5 & $F$ & - & $\mathrm{P}$ & - & - & - & $\mathrm{P}$ & $P$ & $P$ & $P$ & - & - & - & $P$ & - \\
\hline F.B.C. & $\mathrm{H}$ & 7,3 & $\bar{M}$ & - & $\mathrm{P}$ & - & - & - & $\mathrm{P}$ & $\mathrm{P}$ & $\mathrm{P}$ & $P$ & - & - & - & $\mathrm{P}$ & - \\
\hline C.J.C.F. & $\bar{H}$ & 7,2 & $\bar{M}$ & - & $\mathrm{P}$ & - & - & - & $\mathrm{P}$ & $\mathrm{P}$ & $\mathrm{P}$ & $P$ & - & - & - & $\mathrm{P}$ & - \\
\hline D.F.C. & $\overline{\mathrm{H}}$ & 7,0 & $\mathrm{~F}$ & - & $\mathrm{P}$ & - & - & - & - & $\mathrm{P}$ & $\mathrm{P}$ & - & - & - & - & $\mathrm{P}$ & - \\
\hline E.C.L. & $\mathrm{H}$ & 7,6 & $\mathrm{~F}$ & - & $\mathrm{P}$ & - & - & - & $\mathrm{P}$ & $\mathrm{P}$ & $\mathrm{P}$ & $\mathrm{P}$ & - & - & - & $\mathrm{P}$ & - \\
\hline R.F.E. & $\mathrm{H}$ & 7,1 & $\bar{M}$ & - & $\mathrm{P}$ & - & - & - & - & $\mathrm{P}$ & $\mathrm{P}$ & - & - & - & - & $\mathrm{P}$ & - \\
\hline S.T.G. & $\mathrm{H}$ & 7,4 & $\mathrm{M}$ & - & $\mathrm{P}$ & - & - & - & $\mathrm{P}$ & $\mathrm{P}$ & $\mathrm{P}$ & $P$ & - & - & - & $\mathrm{P}$ & - \\
\hline R.F.B. & $\overline{\mathrm{H}}$ & 7,7 & $\mathrm{M}$ & - & $\mathrm{P}$ & - & - & - & $\mathrm{P}$ & $P$ & $P$ & $P$ & - & - & - & $P$ & - \\
\hline R.R.D. & $\mathrm{H}$ & 7,6 & $\mathrm{M}$ & - & $\mathrm{P}$ & - & - & - & $\mathrm{P}$ & $\mathrm{P}$ & $\mathrm{P}$ & $P$ & - & - & - & $\mathrm{P}$ & - \\
\hline J.A.R.C.M. & $\mathrm{H}$ & 7,9 & $\mathrm{M}$ & - & $\mathrm{P}$ & - & - & - & - & $\mathrm{P}$ & $\mathrm{P}$ & - & - & - & - & $\mathrm{P}$ & - \\
\hline B.M.L. & $\overline{\mathrm{H}}$ & 7,3 & $\bar{M}$ & - & $\mathrm{P}$ & - & - & - & $P$ & $P$ & $P$ & - & - & - & - & $P$ & - \\
\hline R.O.B.A. & $\mathrm{H}$ & 7,5 & $\bar{M}$ & - & $\mathrm{P}$ & - & - & - & - & $\mathrm{P}$ & $\mathrm{P}$ & $P$ & - & - & - & $\mathrm{P}$ & - \\
\hline M.P.P. & $\mathrm{H}$ & 7,6 & $F$ & - & $\mathrm{P}$ & - & - & - & $\mathrm{P}$ & $P$ & $P$ & $\mathrm{P}$ & - & - & - & $P$ & - \\
\hline T.F.D. & $\mathrm{H}$ & 7,0 & $\mathrm{M}$ & - & $\mathrm{P}$ & - & - & - & - & $\mathrm{P}$ & $\mathrm{P}$ & $P$ & - & - & - & $P$ & - \\
\hline C.L.C. & $\overline{\mathrm{H}}$ & 7,1 & $\mathrm{~F}$ & - & $\mathrm{P}$ & - & - & - & $\mathrm{P}$ & $P$ & $\mathrm{P}$ & $P$ & - & - & - & $P$ & - \\
\hline T.S.N.J. & $\mathrm{H}$ & 7,8 & $M$ & - & $\mathrm{P}$ & - & - & - & $\mathrm{P}$ & $\mathrm{P}$ & $\mathrm{P}$ & $\mathrm{P}$ & - & - & - & $\mathrm{P}$ & - \\
\hline O.C.C. & $\mathrm{H}$ & 7,2 & $M$ & - & $P$ & - & - & - & $\mathrm{P}$ & $\mathrm{P}$ & $P$ & $P$ & - & - & - & $\mathrm{P}$ & - \\
\hline P.B.B.M. & $\mathrm{H}$ & 7,8 & $\mathrm{~F}$ & - & $\mathrm{P}$ & - & - & - & $\mathrm{P}$ & $\mathrm{P}$ & $\mathrm{P}$ & $\mathrm{P}$ & - & - & - & $\mathrm{P}$ & - \\
\hline M.H.T. & $\mathrm{H}$ & 7,0 & $F$ & - & $P$ & - & - & - & - & - & - & - & - & - & - & $P$ & - \\
\hline F.B. & $\overline{\mathrm{H}}$ & 7,5 & $\mathrm{~F}$ & - & $P$ & - & - & - & $P$ & $P$ & $P$ & $P$ & - & - & - & $P$ & - \\
\hline A.B.S.M. & $\mathrm{H}$ & 7,9 & $\mathrm{~F}$ & - & $\mathrm{P}$ & - & - & - & $\mathrm{P}$ & $\mathrm{P}$ & $\mathrm{P}$ & $\mathrm{P}$ & - & - & - & $\mathrm{P}$ & - \\
\hline C.B.J. & $\mathrm{H}$ & 7,5 & $F$ & - & $\mathrm{P}$ & - & - & - & $\mathrm{P}$ & $\mathrm{P}$ & $P$ & $P$ & - & - & - & $P$ & - \\
\hline D.A.M. & $\mathrm{H}$ & 7,5 & $\mathrm{M}$ & - & $P$ & - & - & - & - & $\mathrm{P}$ & $\mathrm{P}$ & - & - & - & - & $\mathrm{P}$ & - \\
\hline M.L.P. & $\mathrm{H}$ & 7,0 & $\mathrm{~F}$ & - & $\mathrm{P}$ & - & - & - & $\mathrm{P}$ & $\mathrm{P}$ & $\mathrm{P}$ & $P$ & - & - & - & $\mathrm{P}$ & - \\
\hline L.B. & $\mathrm{H}$ & 7,6 & $\mathrm{~F}$ & - & $\mathrm{P}$ & - & - & - & $P$ & $\mathrm{P}$ & $P$ & $\mathrm{P}$ & - & - & - & $P$ & - \\
\hline A.P.M.B. & $\mathrm{H}$ & 7,0 & $\mathrm{~F}$ & - & $\mathrm{P}$ & - & - & - & $\mathrm{P}$ & $\mathrm{P}$ & $\mathrm{P}$ & $P$ & - & - & - & $\mathrm{P}$ & - \\
\hline
\end{tabular}


Tabela A-10

\begin{tabular}{|c|c|c|c|c|c|c|c|c|c|c|c|c|c|c|c|c|c|}
\hline Nome & Grupo & Idade & Gênero & 17 & 16 & 15 & 14 & 13 & 12 & 11 & 21 & 22 & 23 & 24 & 25 & 26 & 27 \\
\hline A.P.T. & V & 8,6 & $F$ & - & $\mathrm{P}$ & - & - & - & $\mathrm{P}$ & $\mathrm{P}$ & $\mathrm{P}$ & $\mathrm{P}$ & - & - & - & $\mathrm{P}$ & - \\
\hline J.M.R.M. & $\mathrm{V}$ & 8,8 & $\mathrm{M}$ & - & $P$ & - & - & - & - & $P$ & $P$ & $P$ & - & - & - & $P$ & - \\
\hline T.V.S. & $\mathrm{V}$ & 8,0 & $M$ & - & $\mathrm{P}$ & - & - & - & $\mathrm{P}$ & $\mathrm{P}$ & $\mathrm{P}$ & $P$ & - & $\mathrm{P}$ & - & $\mathrm{P}$ & - \\
\hline D.F.D. & V & 8,0 & $M$ & - & $P$ & - & - & - & - & $\mathrm{P}$ & $\mathrm{P}$ & - & - & - & - & $P$ & - \\
\hline R.A.A.P.R. & V & 8,9 & $\mathrm{~F}$ & - & $P$ & - & - & - & $\mathrm{P}$ & $\mathrm{P}$ & $P$ & $P$ & - & - & - & $P$ & - \\
\hline A.I.M.B. & $\mathrm{V}$ & 8,4 & $F$ & - & $\mathrm{P}$ & - & - & - & $\mathrm{P}$ & $\mathrm{P}$ & $\mathrm{P}$ & $\mathrm{P}$ & - & - & - & $\mathrm{P}$ & - \\
\hline A.C.M. & V & 8,6 & $\mathrm{~F}$ & - & $\mathrm{P}$ & - & - & - & $\mathrm{P}$ & $\mathrm{P}$ & $\mathrm{P}$ & $\mathrm{P}$ & - & - & - & $\mathrm{P}$ & - \\
\hline E.P.B. & $\mathrm{V}$ & 8,9 & $\mathrm{~F}$ & - & $P$ & $P$ & $P$ & - & $P$ & $\mathrm{P}$ & $P$ & $P$ & - & - & - & $\mathrm{P}$ & - \\
\hline E.C.M. & $\mathrm{V}$ & 8,9 & $\mathrm{~F}$ & - & $\mathrm{P}$ & - & - & - & - & $\mathrm{P}$ & $\mathrm{P}$ & - & - & - & - & $\mathrm{P}$ & - \\
\hline A.L.M. & $\mathrm{V}$ & 8,3 & $\mathrm{~F}$ & - & $P$ & - & - & - & $\mathrm{P}$ & $\mathrm{P}$ & $\mathrm{P}$ & - & - & - & - & $\mathrm{P}$ & - \\
\hline J.C.M.J. & $\mathrm{V}$ & 8,0 & $M$ & - & $P$ & - & - & - & - & $P$ & $\mathrm{P}$ & - & - & - & - & $P$ & - \\
\hline A.F.G. & $\mathrm{V}$ & 8,5 & $\mathrm{M}$ & - & $\mathrm{P}$ & - & - & - & $\mathrm{P}$ & $\mathrm{P}$ & $\mathrm{P}$ & $\mathrm{P}$ & - & - & - & $\mathrm{P}$ & - \\
\hline M.A.P.T. & $\mathrm{V}$ & 8,0 & $M$ & - & $P$ & - & - & - & $\mathrm{P}$ & $\mathrm{P}$ & $\mathrm{P}$ & $P$ & - & - & - & $\mathrm{P}$ & - \\
\hline P.B.J. & $\mathrm{V}$ & 8,6 & $\mathrm{M}$ & - & $P$ & - & - & - & $P$ & $P$ & $P$ & $P$ & - & $P$ & $P$ & $P$ & - \\
\hline T.C.C.C. & V & 8,5 & $\mathrm{~F}$ & - & $\mathrm{P}$ & - & - & - & $\mathrm{P}$ & $\mathrm{P}$ & $P$ & $P$ & - & $P$ & - & $\mathrm{P}$ & - \\
\hline M.Q.B. & V & 8,6 & $\mathrm{M}$ & - & $P$ & - & - & - & $\mathrm{P}$ & $\mathrm{P}$ & $P$ & $P$ & $P$ & $\mathrm{P}$ & - & $\mathrm{P}$ & - \\
\hline R.A.S.S. & $\mathrm{V}$ & 8,3 & $\mathrm{~F}$ & - & $\mathrm{P}$ & - & - & - & - & - & - & - & - & - & - & $\mathrm{P}$ & - \\
\hline R.B.R. & $\mathrm{V}$ & 8,1 & $\mathrm{~F}$ & - & $\mathrm{P}$ & - & - & - & - & - & - & - & - & - & - & $\mathrm{P}$ & - \\
\hline F.B.A. & $\mathrm{V}$ & 8,3 & $F$ & - & $\mathrm{P}$ & - & - & - & $\mathrm{P}$ & $\mathrm{P}$ & $\mathrm{P}$ & $\mathrm{P}$ & - & - & - & $\mathrm{P}$ & - \\
\hline M.F.G. & $\mathrm{V}$ & 8,0 & $\mathrm{~F}$ & - & $\mathrm{P}$ & - & - & - & $\mathrm{P}$ & $\mathrm{P}$ & $\mathrm{P}$ & $\mathrm{P}$ & - & - & - & $\mathrm{P}$ & - \\
\hline S.D. & V & 8,9 & $\mathrm{~F}$ & - & $P$ & - & $P$ & - & $\mathrm{P}$ & $P$ & $P$ & $P$ & - & - & - & $\mathrm{P}$ & - \\
\hline F.B.R. & V & 8,0 & $F$ & - & $\mathrm{P}$ & - & - & - & - & $\mathrm{P}$ & $\mathrm{P}$ & - & - & - & - & $\mathrm{P}$ & - \\
\hline E.F.Z. & $\mathrm{V}$ & 8,3 & $\mathrm{~F}$ & - & $\mathrm{P}$ & - & - & - & $\mathrm{P}$ & $\mathrm{P}$ & $\mathrm{P}$ & $\mathrm{P}$ & - & - & - & $\mathrm{P}$ & - \\
\hline A.R.F. & $\mathrm{V}$ & 8,9 & $M$ & - & $\mathrm{P}$ & - & - & - & $\mathrm{P}$ & $\mathrm{P}$ & $\mathrm{P}$ & $\mathrm{P}$ & - & - & - & $\mathrm{P}$ & - \\
\hline M.G.T. & $\mathrm{V}$ & 8,6 & $M$ & - & $P$ & - & $\mathrm{P}$ & - & $\mathrm{P}$ & $\mathrm{P}$ & $\mathrm{P}$ & $P$ & - & $P$ & $\mathrm{P}$ & $\mathrm{P}$ & - \\
\hline C.V.E. & $\mathrm{V}$ & 8,3 & $F$ & - & $P$ & - & - & - & $\mathrm{P}$ & $P$ & $P$ & $P$ & - & - & - & $P$ & - \\
\hline R.T.D.G. & $\mathrm{V}$ & 8,9 & $\bar{M}$ & - & $\mathrm{P}$ & - & - & - & $\mathrm{P}$ & $\mathrm{P}$ & $\mathrm{P}$ & $\mathrm{P}$ & - & - & - & $\mathrm{P}$ & - \\
\hline G.C.T.N. & $\mathrm{V}$ & 8,0 & $M$ & - & $\mathrm{P}$ & - & - & - & $\mathrm{P}$ & $P$ & $P$ & $\mathrm{P}$ & - & - & - & $P$ & - \\
\hline R.Q. & $\mathrm{V}$ & 8,8 & $M$ & - & $\mathrm{P}$ & - & - & - & - & $P$ & $P$ & $P$ & - & - & - & $P$ & - \\
\hline E.L.C.S. & $\mathrm{V}$ & 8,9 & $\bar{M}$ & - & $\mathrm{P}$ & - & - & - & $\mathrm{P}$ & $\mathrm{P}$ & $\mathrm{P}$ & $\mathrm{P}$ & - & - & - & - & - \\
\hline E.D.B. & $\overline{\mathrm{H}}$ & 8,8 & $\bar{F}$ & - & $\mathrm{P}$ & - & $\mathrm{P}$ & - & $\mathrm{P}$ & $\mathrm{P}$ & $P$ & $\mathrm{P}$ & - & - & - & $\mathrm{P}$ & - \\
\hline C.M.T. & $\overline{\mathrm{H}}$ & 8,9 & $M$ & - & $\mathrm{P}$ & - & - & - & $P$ & $\mathrm{P}$ & $P$ & $\mathrm{P}$ & - & - & - & $P$ & - \\
\hline V.M.A.C. & $\mathrm{H}$ & 8,6 & $\mathrm{~F}$ & - & $\mathrm{P}$ & - & $\mathrm{P}$ & - & $\mathrm{P}$ & $\mathrm{P}$ & $P$ & $\mathrm{P}$ & - & $\mathrm{P}$ & - & $\mathrm{P}$ & - \\
\hline R.P.F. & $\mathrm{H}$ & 8,8 & $M$ & - & $\mathrm{P}$ & - & - & - & $\mathrm{P}$ & $\mathrm{P}$ & $P$ & $\mathrm{P}$ & - & - & - & $\mathrm{P}$ & - \\
\hline A.C.D. & $\mathrm{H}$ & 8,5 & $\mathrm{~F}$ & - & $\mathrm{P}$ & - & - & - & $\mathrm{P}$ & $P$ & $P$ & $\mathrm{P}$ & - & - & - & $P$ & - \\
\hline C.J.C.F. & $\mathrm{H}$ & 8,3 & $\mathrm{M}$ & - & $\mathrm{P}$ & - & - & - & $\mathrm{P}$ & $\mathrm{P}$ & $P$ & $\mathrm{P}$ & - & - & - & $\mathrm{P}$ & - \\
\hline D.F.C. & $\mathrm{H}$ & 8,1 & $F$ & - & $\mathrm{P}$ & - & - & - & - & $\mathrm{P}$ & $\mathrm{P}$ & - & - & - & - & $\mathrm{P}$ & - \\
\hline F.S. & $\mathrm{H}$ & 8,5 & M & - & $\mathrm{P}$ & - & - & - & $P$ & $\mathrm{P}$ & $\mathrm{P}$ & $\mathrm{P}$ & - & - & - & $\mathrm{P}$ & - \\
\hline E.C.L. & $\mathrm{H}$ & 8,6 & $\mathrm{~F}$ & - & $\mathrm{P}$ & - & - & - & $\mathrm{P}$ & $\mathrm{P}$ & $P$ & $\mathrm{P}$ & - & - & - & $\mathrm{P}$ & - \\
\hline R.F.E. & $\mathrm{H}$ & 8,2 & $\bar{M}$ & - & $\mathrm{P}$ & - & - & - & $\mathrm{P}$ & $P$ & $P$ & $\mathrm{P}$ & - & - & - & $P$ & - \\
\hline R.F.B. & $\mathrm{H}$ & 8,6 & $M$ & - & $\mathrm{P}$ & - & - & - & - & $\mathrm{P}$ & $P$ & $P$ & - & - & - & $\mathrm{P}$ & - \\
\hline R.R.D. & $\mathrm{H}$ & 8,6 & $M$ & - & $\mathrm{P}$ & $P$ & - & - & - & $P$ & $P$ & $P$ & - & - & - & $P$ & - \\
\hline J.A.R.C.M. & $\mathrm{H}$ & 8,9 & $M$ & - & $\mathrm{P}$ & - & - & - & - & $\mathrm{P}$ & $\mathrm{P}$ & - & - & - & - & $\mathrm{P}$ & - \\
\hline B.M.L. & $\mathrm{H}$ & 8,1 & $M$ & - & $\mathrm{P}$ & - & - & - & $\mathrm{P}$ & $\mathrm{P}$ & $P$ & $P$ & - & - & - & $\mathrm{P}$ & - \\
\hline R.O.B.A. & $\mathrm{H}$ & 8,5 & $\mathrm{M}$ & - & $\mathrm{P}$ & - & - & - & $\mathrm{P}$ & $\mathrm{P}$ & $\mathrm{P}$ & $\mathrm{P}$ & - & - & - & $\mathrm{P}$ & - \\
\hline C.F.Z.S. & $\mathrm{H}$ & 8,1 & $\mathrm{~F}$ & - & $\mathrm{P}$ & - & - & - & $\mathrm{P}$ & $\mathrm{P}$ & $\mathrm{P}$ & $\mathrm{P}$ & - & - & - & $\mathrm{P}$ & - \\
\hline M.P.P. & $\mathrm{H}$ & 8,5 & $\mathrm{~F}$ & - & $\mathrm{P}$ & - & - & - & $\mathrm{P}$ & $\mathrm{P}$ & $\mathrm{P}$ & $\mathrm{P}$ & - & - & - & $\mathrm{P}$ & - \\
\hline T.F.D. & $\mathrm{H}$ & 8,0 & $\mathrm{M}$ & - & $\mathrm{P}$ & - & - & - & $\mathrm{P}$ & $\mathrm{P}$ & $\mathrm{P}$ & $\mathrm{P}$ & - & - & - & $\mathrm{P}$ & - \\
\hline T.S.N.J. & $\mathrm{H}$ & 8,5 & $\mathrm{M}$ & - & $\mathrm{P}$ & - & - & - & $\mathrm{P}$ & $\mathrm{P}$ & $\mathrm{P}$ & - & - & - & - & $P$ & - \\
\hline O.C.C. & $\mathrm{H}$ & 8,0 & $M$ & - & $P$ & - & - & - & $\mathrm{P}$ & $\mathrm{P}$ & $P$ & $P$ & - & - & - & $\mathrm{P}$ & - \\
\hline J.A.A.C. & $\mathrm{H}$ & 8,8 & $\mathrm{M}$ & - & $\mathrm{P}$ & - & - & - & $\mathrm{P}$ & $\mathrm{P}$ & $P$ & $\mathrm{P}$ & - & - & - & $\mathrm{P}$ & - \\
\hline P.B.B.M. & $\mathrm{H}$ & 8,8 & $\mathrm{~F}$ & - & $\mathrm{P}$ & - & - & - & $P$ & $P$ & $\mathrm{P}$ & $P$ & - & - & - & $P$ & - \\
\hline M.H.T. & $\mathrm{H}$ & 8,2 & $F$ & - & $\mathrm{P}$ & - & - & - & - & $\mathrm{P}$ & $P$ & - & - & - & - & $\mathrm{P}$ & - \\
\hline F.B. & $\mathrm{H}$ & 8,5 & $\mathrm{~F}$ & - & $\mathrm{P}$ & - & $P$ & - & $\mathrm{P}$ & $\mathrm{P}$ & $\mathrm{P}$ & $\mathrm{P}$ & - & - & - & $P$ & - \\
\hline A.B.S.M. & $\mathrm{H}$ & 8,9 & $\mathrm{~F}$ & - & $P$ & - & - & - & - & $P$ & $P$ & - & - & - & - & $P$ & - \\
\hline C.B.J. & $\mathrm{H}$ & 8,4 & $\bar{F}$ & - & $\mathrm{P}$ & - & - & - & $\mathrm{P}$ & $P$ & $\mathrm{P}$ & $\mathrm{P}$ & - & - & - & $P$ & - \\
\hline M.L.P. & $\mathrm{H}$ & 8,0 & $\mathrm{~F}$ & - & $\mathrm{P}$ & - & - & - & $\mathrm{P}$ & $\mathrm{P}$ & $P$ & $\mathrm{P}$ & - & - & - & $\mathrm{P}$ & - \\
\hline L.B. & $\mathrm{H}$ & 8,6 & $\mathrm{~F}$ & - & $\mathrm{P}$ & - & - & - & $\mathrm{P}$ & $\mathrm{P}$ & $\mathrm{P}$ & $\mathrm{P}$ & - & - & - & $\mathrm{P}$ & - \\
\hline A.P.M.B. & $\overline{\mathrm{H}}$ & 8,0 & $\mathrm{~F}$ & - & $\mathrm{P}$ & - & - & - & $\mathrm{P}$ & $\mathrm{P}$ & $\mathrm{P}$ & $\mathrm{P}$ & - & - & - & $\mathrm{P}$ & - \\
\hline P.S.E. & $\mathrm{H}$ & 8,4 & $\mathrm{~F}$ & - & $P$ & - & - & - & - & $\mathrm{P}$ & $P$ & - & - & - & - & $P$ & - \\
\hline
\end{tabular}


Tabela A-11

\begin{tabular}{|c|c|c|c|c|c|c|c|c|c|c|c|c|c|c|c|c|c|}
\hline Nome & Grupo & Idade & Gênero & 37 & 36 & 35 & 34 & 33 & 32 & 31 & 41 & 42 & 43 & 44 & 45 & 46 & 47 \\
\hline A.P.T. & V & 8,6 & $\mathrm{~F}$ & - & $\mathrm{P}$ & - & - & - & $\mathrm{P}$ & $\mathrm{P}$ & $\mathrm{P}$ & $\mathrm{P}$ & - & - & - & $\mathrm{P}$ & - \\
\hline J.M.R.M. & $\bar{V}$ & 8,8 & $\mathrm{M}$ & - & $\mathrm{P}$ & - & - & - & $\mathrm{P}$ & $\mathrm{P}$ & $P$ & $P$ & - & - & - & $P$ & - \\
\hline T.V.S. & $\mathrm{V}$ & 8,0 & $\mathrm{M}$ & - & $\mathrm{P}$ & - & - & - & $\mathrm{P}$ & $\mathrm{P}$ & $\mathrm{P}$ & $\mathrm{P}$ & - & $\begin{array}{lll}- & \\
\end{array}$ & - & $\mathrm{P}$ & - \\
\hline D.F.D. & $\mathrm{V}$ & 8,0 & $M$ & - & $\mathrm{P}$ & - & - & - & $\mathrm{P}$ & $\mathrm{P}$ & $\mathrm{P}$ & $\mathrm{P}$ & - & - & - & $\mathrm{P}$ & - \\
\hline R.A.A.P.R. & $\mathrm{V}$ & 8,9 & $\mathrm{~F}$ & - & $\mathrm{P}$ & - & - & - & $\mathrm{P}$ & $\mathrm{P}$ & $\mathrm{P}$ & $P$ & - & - & - & $\mathrm{P}$ & - \\
\hline A.I.M.B. & $\mathrm{V}$ & 8,4 & $F$ & - & $\mathrm{P}$ & - & - & - & $\mathrm{P}$ & $\mathrm{P}$ & $\mathrm{P}$ & $P$ & - & - & - & $\mathrm{P}$ & - \\
\hline A.C.M. & $\mathrm{V}$ & 8,6 & $\mathrm{~F}$ & - & $P$ & - & - & - & $P$ & $P$ & $P$ & $P$ & - & - & - & $P$ & - \\
\hline E.P.B. & V & 8,9 & $\mathrm{~F}$ & - & $\mathrm{P}$ & - & - & - & $\mathrm{P}$ & $\mathrm{P}$ & $\mathrm{P}$ & $P$ & - & - & - & $\mathrm{P}$ & - \\
\hline E.C.M. & $\mathrm{V}$ & 8,9 & $\mathrm{~F}$ & - & $\mathrm{P}$ & - & - & - & $P$ & $P$ & $P$ & $P$ & - & - & - & $P$ & - \\
\hline A.L.M. & $\mathrm{V}$ & 8,3 & $\mathrm{~F}$ & - & $\mathrm{P}$ & - & - & - & $\mathrm{P}$ & $\mathrm{P}$ & $\mathrm{P}$ & $P$ & - & - & - & $\mathrm{P}$ & - \\
\hline J.C.M.J. & V & 8,0 & $\mathrm{M}$ & - & $\mathrm{P}$ & - & - & - & - & $P$ & $P$ & - & - & - & - & $\mathrm{P}$ & - \\
\hline A.F.G. & $\mathrm{V}$ & 8,5 & $\mathrm{M}$ & - & $\mathrm{P}$ & - & - & - & $\mathrm{P}$ & $P$ & $P$ & $P$ & - & - & - & $\mathrm{P}$ & - \\
\hline M.A.P.T. & $\mathrm{V}$ & 8,0 & $\mathrm{M}$ & - & $\mathrm{P}$ & - & - & - & $\mathrm{P}$ & $\mathrm{P}$ & $\mathrm{P}$ & $P$ & - & - & - & $\mathrm{P}$ & - \\
\hline P.B.J. & V & 8,6 & $M$ & - & $P$ & - & - & - & $P$ & $P$ & $P$ & $P$ & - & - & - & $P$ & - \\
\hline T.C.C.C. & V & 8,5 & $\mathrm{~F}$ & - & $\mathrm{P}$ & - & - & $\mathrm{P}$ & $\mathrm{P}$ & $\mathrm{P}$ & $\mathrm{P}$ & $P$ & - & - & - & $\mathrm{P}$ & - \\
\hline M.Q.B. & $\mathrm{V}$ & 8,6 & $\bar{M}$ & - & $\mathrm{P}$ & - & $P$ & $\mathrm{P}$ & $\mathrm{P}$ & $\mathrm{P}$ & $P$ & $P$ & $P$ & $\mathrm{P}$ & - & $P$ & - \\
\hline R.A.S.S. & $\mathrm{V}$ & 8,3 & $\mathrm{~F}$ & - & $\mathrm{P}$ & - & - & - & - & $\mathrm{P}$ & $\mathrm{P}$ & - & - & - & - & $\mathrm{P}$ & - \\
\hline R.B.R. & $\mathrm{V}$ & 8,1 & $\mathrm{~F}$ & - & $\mathrm{P}$ & - & - & - & - & $\mathrm{P}$ & $\mathrm{P}$ & - & - & - & - & $\mathrm{P}$ & - \\
\hline F.B.A. & $\mathrm{V}$ & 8,3 & $\mathrm{~F}$ & - & $\mathrm{P}$ & - & - & - & $\mathrm{P}$ & $\mathrm{P}$ & $\mathrm{P}$ & $P$ & - & - & - & $\mathrm{P}$ & - \\
\hline M.F.G. & $\mathrm{V}$ & 8,0 & $\mathrm{~F}$ & - & $P$ & - & - & - & $\mathrm{P}$ & $\mathrm{P}$ & $\mathrm{P}$ & $P$ & - & - & - & $\mathrm{P}$ & - \\
\hline S.D. & $\mathrm{V}$ & 8,9 & $\mathrm{~F}$ & - & $\mathrm{P}$ & - & - & $\mathrm{P}$ & $\mathrm{P}$ & $\mathrm{P}$ & $\mathrm{P}$ & $P$ & $P$ & - & - & $P$ & - \\
\hline F.B.R. & $\mathrm{V}$ & 8,0 & $F$ & - & $\mathrm{P}$ & - & - & - & $\mathrm{P}$ & $P$ & $\mathrm{P}$ & $P$ & - & - & - & $\mathrm{P}$ & - \\
\hline E.F.Z. & $\mathrm{V}$ & 8,3 & $\mathrm{~F}$ & - & $\mathrm{P}$ & - & - & - & $\mathrm{P}$ & $\mathrm{P}$ & $\mathrm{P}$ & $P$ & - & - & - & $\mathrm{P}$ & - \\
\hline A.R.F. & V & 8,9 & $\bar{M}$ & - & $\mathrm{P}$ & - & - & $\mathrm{P}$ & $\mathrm{P}$ & $\mathrm{P}$ & $\mathrm{P}$ & $P$ & - & - & - & $\mathrm{P}$ & - \\
\hline M.G.T. & $\mathrm{V}$ & 8,6 & $\mathrm{M}$ & - & $P$ & - & $P$ & $\mathrm{P}$ & $P$ & $P$ & $\mathrm{P}$ & $P$ & $P$ & $P$ & - & $P$ & - \\
\hline C.V.E. & $\mathrm{V}$ & 8,3 & $\mathrm{~F}$ & - & $\mathrm{P}$ & - & - & - & $\mathrm{P}$ & $\mathrm{P}$ & $\mathrm{P}$ & $P$ & - & - & - & $\mathrm{P}$ & - \\
\hline R.T.D.G. & $\mathrm{V}$ & 8,9 & $M$ & - & $\mathrm{P}$ & - & - & - & $\mathrm{P}$ & $\mathrm{P}$ & $\mathrm{P}$ & $P$ & - & - & - & $\mathrm{P}$ & - \\
\hline G.C.T.N. & V & 8,0 & $M$ & - & $\mathrm{P}$ & - & - & - & $\mathrm{P}$ & $\mathrm{P}$ & $\mathrm{P}$ & $P$ & - & - & - & $\mathrm{P}$ & - \\
\hline R.Q. & V & 8,8 & $\mathrm{M}$ & - & $\mathrm{P}$ & - & - & - & $\mathrm{P}$ & $\mathrm{P}$ & $\mathrm{P}$ & $P$ & - & - & - & $\mathrm{P}$ & - \\
\hline E.L.C.S. & $\mathrm{V}$ & 8,9 & $\bar{M}$ & - & $\mathrm{P}$ & - & - & - & $\mathrm{P}$ & $\mathrm{P}$ & $\mathrm{P}$ & $P$ & - & $\mathrm{P}$ & - & $\mathrm{P}$ & - \\
\hline E.D.B. & $\mathrm{H}$ & 8,8 & $F$ & - & $\mathrm{P}$ & - & $\mathrm{P}$ & $P$ & $\mathrm{P}$ & $\mathrm{P}$ & $P$ & $P$ & - & - & - & $P$ & - \\
\hline C.M.T. & $\mathrm{H}$ & 8,9 & $\bar{M}$ & - & $P$ & - & - & - & $P$ & $\mathrm{P}$ & $P$ & $P$ & - & - & - & $P$ & - \\
\hline V.M.A.C. & $\mathrm{H}$ & 8,6 & $F$ & - & $\mathrm{P}$ & - & - & $P$ & $\mathrm{P}$ & $\mathrm{P}$ & $\mathrm{P}$ & $P$ & - & $\mathrm{P}$ & - & $P$ & - \\
\hline R.P.F. & $\mathrm{H}$ & 8,8 & $M$ & - & $P$ & - & - & - & $P$ & $P$ & $P$ & $P$ & - & - & - & $P$ & - \\
\hline A.C.D. & $\mathrm{H}$ & 8,5 & $\mathrm{~F}$ & - & $\mathrm{P}$ & - & $\mathrm{P}$ & $\mathrm{P}$ & $\mathrm{P}$ & $\mathrm{P}$ & $\mathrm{P}$ & $\mathrm{P}$ & $\mathrm{P}$ & - & - & $\mathrm{P}$ & - \\
\hline C.J.C.F. & $\mathrm{H}$ & 8,3 & $\bar{M}$ & - & $\mathrm{P}$ & - & - & - & $\mathrm{P}$ & $\mathrm{P}$ & $\mathrm{P}$ & $P$ & - & - & - & $\mathrm{P}$ & - \\
\hline D.F.C. & $\mathrm{H}$ & 8,1 & $\mathrm{~F}$ & - & $\mathrm{P}$ & - & - & - & $\mathrm{P}$ & $\mathrm{P}$ & $\mathrm{P}$ & $P$ & - & - & - & $\mathrm{P}$ & - \\
\hline F.S. & $\mathrm{H}$ & 8,5 & $\bar{M}$ & - & $\mathrm{P}$ & - & - & - & $\mathrm{P}$ & $\mathrm{P}$ & $\mathrm{P}$ & - & - & - & - & $\mathrm{P}$ & - \\
\hline E.C.L. & $\mathrm{H}$ & 8,6 & $\mathrm{~F}$ & - & $\mathrm{P}$ & - & - & - & $\mathrm{P}$ & $\mathrm{P}$ & $\mathrm{P}$ & $\mathrm{P}$ & $\mathrm{P}$ & - & - & $\mathrm{P}$ & - \\
\hline R.F.E. & $\mathrm{H}$ & 8,2 & $\bar{M}$ & - & $\mathrm{P}$ & - & - & - & $\mathrm{P}$ & $\mathrm{P}$ & $\mathrm{P}$ & $P$ & - & - & - & $\mathrm{P}$ & - \\
\hline R.F.B. & $\mathrm{H}$ & 8,6 & $M$ & - & $\mathrm{P}$ & - & - & - & $\mathrm{P}$ & $\mathrm{P}$ & $\mathrm{P}$ & $P$ & - & - & - & $\mathrm{P}$ & - \\
\hline R.R.D. & $\overline{\mathrm{H}}$ & 8,6 & $\bar{M}$ & - & $P$ & - & - & - & $P$ & $\mathrm{P}$ & $P$ & $P$ & - & - & - & $P$ & - \\
\hline J.A.R.C.M. & $\mathrm{H}$ & 8,9 & $M$ & - & $\mathrm{P}$ & - & - & - & $\mathrm{P}$ & $\mathrm{P}$ & $\mathrm{P}$ & $P$ & - & - & - & $\mathrm{P}$ & - \\
\hline B.M.L. & $\mathrm{H}$ & 8,1 & $\bar{M}$ & - & $\mathrm{P}$ & - & - & - & $\mathrm{P}$ & $\mathrm{P}$ & $\mathrm{P}$ & $P$ & - & - & - & $\mathrm{P}$ & - \\
\hline R.O.B.A. & $\mathrm{H}$ & 8,5 & $M$ & - & $\mathrm{P}$ & - & - & - & $\mathrm{P}$ & $\mathrm{P}$ & $\mathrm{P}$ & $\mathrm{P}$ & - & - & - & $\mathrm{P}$ & - \\
\hline C.F.Z.S. & $\mathrm{H}$ & 8,1 & $\mathrm{~F}$ & - & $\mathrm{P}$ & - & - & - & $\mathrm{P}$ & $\mathrm{P}$ & $\mathrm{P}$ & $P$ & - & - & - & $\mathrm{P}$ & - \\
\hline M.P.P. & $\mathrm{H}$ & 8,5 & $F$ & - & $P$ & - & - & - & $P$ & $P$ & $P$ & $P$ & - & - & - & $P$ & - \\
\hline T.F.D. & $\mathrm{H}$ & 8,0 & $\mathrm{M}$ & - & $P$ & - & - & - & $P$ & $\mathrm{P}$ & $\mathrm{P}$ & $P$ & - & - & - & $P$ & - \\
\hline T.S.N.J. & $\overline{\mathrm{H}}$ & 8,5 & $\mathrm{M}$ & - & $\mathrm{P}$ & - & - & - & $\mathrm{P}$ & $\mathrm{P}$ & $\mathrm{P}$ & $P$ & - & - & - & $P$ & - \\
\hline O.C.C. & $\mathrm{H}$ & 8,0 & $M$ & - & $\mathrm{P}$ & - & - & - & $\mathrm{P}$ & $\mathrm{P}$ & $\mathrm{P}$ & $\mathrm{P}$ & - & - & - & $\mathrm{P}$ & - \\
\hline J.A.A.C. & $\mathrm{H}$ & 8,8 & $M$ & - & $\mathrm{P}$ & - & - & - & $\mathrm{P}$ & $\mathrm{P}$ & $\mathrm{P}$ & $\mathrm{P}$ & - & - & - & $\mathrm{P}$ & - \\
\hline P.B.B.M. & $\mathrm{H}$ & 8,8 & $\mathrm{~F}$ & - & $\mathrm{P}$ & - & - & - & $\mathrm{P}$ & $\mathrm{P}$ & $\mathrm{P}$ & $\mathrm{P}$ & - & - & - & $\mathrm{P}$ & - \\
\hline M.H.T. & $\mathrm{H}$ & 8,2 & $\mathrm{~F}$ & - & $\mathrm{P}$ & - & - & - & $\mathrm{P}$ & $\mathrm{P}$ & $\mathrm{P}$ & $\mathrm{P}$ & - & - & - & $\mathrm{P}$ & - \\
\hline F.B. & $\mathrm{H}$ & 8,5 & $\mathrm{~F}$ & - & $\mathrm{P}$ & - & - & - & $\mathrm{P}$ & $\mathrm{P}$ & $\mathrm{P}$ & $\mathrm{P}$ & - & - & - & $\mathrm{P}$ & - \\
\hline A.B.S.M. & $\mathrm{H}$ & 8,9 & $\mathrm{~F}$ & - & $\mathrm{P}$ & - & - & - & $\mathrm{P}$ & $\mathrm{P}$ & $\mathrm{P}$ & $\mathrm{P}$ & - & - & - & $\mathrm{P}$ & - \\
\hline C.B.J. & $\mathrm{H}$ & 8,4 & $F$ & - & $\mathrm{P}$ & - & - & - & $\mathrm{P}$ & $\mathrm{P}$ & $P$ & $P$ & - & - & - & $P$ & - \\
\hline M.L.P. & $\mathrm{H}$ & 8,0 & $\mathrm{~F}$ & - & $P$ & - & - & - & $P$ & $P$ & $P$ & $P$ & - & - & - & $P$ & - \\
\hline L.B. & $\mathrm{H}$ & 8,6 & $\mathrm{~F}$ & - & $\mathrm{P}$ & - & - & - & $\mathrm{P}$ & $\mathrm{P}$ & $\mathrm{P}$ & $P$ & - & - & $\mathrm{P}$ & $\mathrm{P}$ & - \\
\hline A.P.M.B. & $\mathrm{H}$ & 8,0 & $\mathrm{~F}$ & - & $\mathrm{P}$ & - & - & - & $P$ & $P$ & $P$ & $\mathrm{P}$ & - & - & - & $P$ & - \\
\hline P.S.E. & $\mathrm{H}$ & 8,4 & $F$ & - & $\mathrm{P}$ & - & - & - & $\mathrm{P}$ & $\mathrm{P}$ & $\mathrm{P}$ & $\mathrm{P}$ & - & - & - & $\mathrm{P}$ & - \\
\hline
\end{tabular}


Tabela A-12

\begin{tabular}{|c|c|c|c|c|c|c|c|c|c|c|c|c|c|c|c|c|c|}
\hline Nome & Grupo & Idade & Gênero & 17 & 16 & 15 & 14 & 13 & 12 & 11 & 21 & 22 & 23 & 24 & 25 & 26 & 27 \\
\hline A.P.T. & V & 9,7 & $\mathrm{~F}$ & - & $\mathrm{P}$ & - & - & - & $\mathrm{P}$ & $\mathrm{P}$ & $\mathrm{P}$ & $\mathrm{P}$ & - & - & - & $\mathrm{P}$ & - \\
\hline J.M.R.M. & $\bar{V}$ & 9,9 & $\bar{M}$ & - & $\mathrm{P}$ & - & - & - & $\mathrm{P}$ & $\mathrm{P}$ & $\mathrm{P}$ & $P$ & - & $\mathrm{P}$ & $\mathrm{P}$ & $\mathrm{P}$ & - \\
\hline T.S.C. & $\mathrm{V}$ & 9,3 & $\mathrm{M}$ & - & $\mathrm{P}$ & - & - & - & $\mathrm{P}$ & $\mathrm{P}$ & $\mathrm{P}$ & $P$ & - & - & - & $\mathrm{P}$ & - \\
\hline T.V.S. & $\mathrm{V}$ & 9,0 & $M$ & - & $\mathrm{P}$ & - & - & - & $\mathrm{P}$ & $\mathrm{P}$ & $\mathrm{P}$ & $\mathrm{P}$ & - & $\mathrm{P}$ & - & $\mathrm{P}$ & - \\
\hline R.A.A. & $\mathrm{V}$ & 9,6 & $\bar{M}$ & - & $\mathrm{P}$ & - & - & - & $\mathrm{P}$ & $\mathrm{P}$ & $\mathrm{P}$ & - & - & - & - & $\mathrm{P}$ & - \\
\hline D.F.D. & $\mathrm{V}$ & 9,0 & $\bar{M}$ & - & $\mathrm{P}$ & - & - & - & $\mathrm{P}$ & $\mathrm{P}$ & $P$ & $P$ & - & - & - & $\mathrm{P}$ & - \\
\hline A.C.M. & $\mathrm{V}$ & 9,6 & $\mathrm{~F}$ & - & $\mathrm{P}$ & - & - & - & $\mathrm{P}$ & $\mathrm{P}$ & $\mathrm{P}$ & $P$ & - & $\mathrm{P}$ & $P$ & $\mathrm{P}$ & - \\
\hline E.P.B. & V & 9,8 & $\mathrm{~F}$ & - & $\mathrm{P}$ & $P$ & $\mathrm{P}$ & - & $\mathrm{P}$ & $\mathrm{P}$ & $\mathrm{P}$ & $\mathrm{P}$ & - & $P$ & - & $P$ & - \\
\hline E.C.M. & V & 9,9 & $\mathrm{~F}$ & - & $\mathrm{P}$ & - & - & - & $\mathrm{P}$ & $\mathrm{P}$ & $P$ & $\mathrm{P}$ & - & - & - & $\mathrm{P}$ & - \\
\hline A.L.M. & $\mathrm{V}$ & 9,1 & $\mathrm{~F}$ & - & $\mathrm{P}$ & $\mathrm{P}$ & $\mathrm{P}$ & - & $\mathrm{P}$ & $\mathrm{P}$ & $\mathrm{P}$ & $P$ & - & $\mathrm{P}$ & $P$ & $\mathrm{P}$ & - \\
\hline J.C.M.J. & V & 9,0 & $\mathrm{M}$ & - & $\mathrm{P}$ & - & - & - & - & $\mathrm{P}$ & $P$ & - & - & - & - & $\mathrm{P}$ & - \\
\hline A.F.G. & V & 9,5 & $\mathrm{M}$ & - & $\mathrm{P}$ & - & $\mathrm{P}$ & $\mathrm{P}$ & $P$ & $\mathrm{P}$ & $P$ & $P$ & $\mathrm{P}$ & $P$ & - & $P$ & - \\
\hline M.A.P.T. & $\mathrm{V}$ & 9,1 & $\bar{M}$ & - & $P$ & - & - & - & $P$ & $P$ & $P$ & $P$ & - & - & - & $P$ & - \\
\hline P.B.J. & V & 9,9 & $M$ & - & $\mathrm{P}$ & - & - & - & $\mathrm{P}$ & $\mathrm{P}$ & $\mathrm{P}$ & $P$ & - & $\mathrm{P}$ & $\mathrm{P}$ & $P$ & - \\
\hline R.G.M. & $\mathrm{V}$ & 9,2 & $\mathrm{M}$ & - & $\mathrm{P}$ & - & - & - & $\mathrm{P}$ & $\mathrm{P}$ & $\mathrm{P}$ & $P$ & - & $\mathrm{P}$ & $\mathrm{P}$ & $\mathrm{P}$ & - \\
\hline T.C.C.C. & $\mathrm{V}$ & 9,5 & $\mathrm{~F}$ & - & $\mathrm{P}$ & - & - & - & $\mathrm{P}$ & $\mathrm{P}$ & $\mathrm{P}$ & $P$ & - & $\mathrm{P}$ & - & $P$ & - \\
\hline M.Q.B. & V & 9,5 & $M$ & - & $\mathrm{P}$ & - & $\mathrm{P}$ & $\mathrm{P}$ & $\mathrm{P}$ & $\mathrm{P}$ & $\mathrm{P}$ & $P$ & $\mathrm{P}$ & $\mathrm{P}$ & - & $P$ & - \\
\hline R.B.R. & V & 9,2 & $\mathrm{~F}$ & - & $\mathrm{P}$ & - & - & - & - & $\mathrm{P}$ & $\mathrm{P}$ & - & - & - & - & $\mathrm{P}$ & - \\
\hline F.B.A. & V & 9,4 & $\mathrm{~F}$ & - & $\mathrm{P}$ & - & - & - & $\mathrm{P}$ & $\mathrm{P}$ & $\mathrm{P}$ & $P$ & - & - & - & $\mathrm{P}$ & - \\
\hline M.F.G. & $\mathrm{V}$ & 9,0 & $\mathrm{~F}$ & - & $\mathrm{P}$ & - & - & - & $\mathrm{P}$ & $\mathrm{P}$ & $\mathrm{P}$ & $\mathrm{P}$ & - & - & - & $\mathrm{P}$ & - \\
\hline S.D. & V & 9,9 & $\mathrm{~F}$ & - & $\mathrm{P}$ & - & $\mathrm{P}$ & - & $\mathrm{P}$ & $\mathrm{P}$ & $\mathrm{P}$ & $\mathrm{P}$ & - & $\mathrm{P}$ & - & $P$ & - \\
\hline F.B.R. & $\mathrm{V}$ & 9,0 & $\mathrm{~F}$ & - & $\mathrm{P}$ & - & - & - & $\mathrm{P}$ & $\mathrm{P}$ & $\mathrm{P}$ & $P$ & - & - & - & $P$ & - \\
\hline E.F.Z. & $\overline{\mathrm{V}}$ & 9,4 & $\bar{F}$ & - & $\mathrm{P}$ & - & - & - & $\mathrm{P}$ & $\mathrm{P}$ & $P$ & $\bar{P}$ & - & - & - & $\bar{P}$ & - \\
\hline A.R.F. & V & 9,9 & $\bar{M}$ & - & $P$ & - & - & - & $\mathrm{P}$ & $P$ & $P$ & $P$ & - & - & - & $P$ & - \\
\hline M.G.T. & $\mathrm{V}$ & 9,5 & $\bar{M}$ & - & $\mathrm{P}$ & $\mathrm{P}$ & $\mathrm{P}$ & - & $\mathrm{P}$ & $\mathrm{P}$ & $\mathrm{P}$ & $P$ & $\mathrm{P}$ & $\mathrm{P}$ & $\mathrm{P}$ & $P$ & - \\
\hline C.V.E. & $\mathrm{V}$ & 9,4 & $F$ & - & $\mathrm{P}$ & - & - & - & $\mathrm{P}$ & $\mathrm{P}$ & $\mathrm{P}$ & $P$ & - & - & - & $P$ & - \\
\hline R.T.D.G. & $\mathrm{V}$ & 9,7 & $\bar{M}$ & - & $\mathrm{P}$ & $P$ & - & - & $\mathrm{P}$ & $\mathrm{P}$ & $\mathrm{P}$ & $P$ & - & - & - & $P$ & - \\
\hline R.Q. & V & 9,8 & $M$ & - & $\mathrm{P}$ & - & - & - & $\mathrm{P}$ & $\mathrm{P}$ & $\mathrm{P}$ & $P$ & - & $\mathrm{P}$ & - & $\mathrm{P}$ & - \\
\hline E.L.C.S. & V & 9,9 & $\bar{M}$ & - & $\mathrm{P}$ & - & - & - & $\mathrm{P}$ & $\mathrm{P}$ & $\mathrm{P}$ & $P$ & - & $\mathrm{P}$ & $\mathrm{P}$ & $P$ & - \\
\hline H.J.S.S. & V & 9,6 & $\bar{M}$ & - & $\mathrm{P}$ & - & - & - & $\mathrm{P}$ & $\mathrm{P}$ & $\mathrm{P}$ & $P$ & - & - & - & $\mathrm{P}$ & - \\
\hline C.M.T. & $\mathrm{H}$ & 9,9 & $\bar{M}$ & - & $\mathrm{P}$ & - & - & - & $\mathrm{P}$ & $\mathrm{P}$ & $\mathrm{P}$ & $P$ & - & - & - & $\mathrm{P}$ & - \\
\hline V.M.A.C. & $\mathrm{H}$ & 9,8 & $\mathrm{~F}$ & - & $\mathrm{P}$ & $\mathrm{P}$ & $\mathrm{P}$ & $\mathrm{P}$ & $\mathrm{P}$ & $\mathrm{P}$ & $\mathrm{P}$ & $P$ & $\mathrm{P}$ & $\mathrm{P}$ & $\mathrm{P}$ & $P$ & - \\
\hline R.P.F. & $\mathrm{H}$ & 9,7 & $\bar{M}$ & - & $P$ & - & - & - & $\mathrm{P}$ & $P$ & $P$ & $P$ & - & - & - & $\mathrm{P}$ & - \\
\hline A.C.D. & $\mathrm{H}$ & 9,5 & $\mathrm{~F}$ & - & $P$ & $P$ & - & - & $P$ & $\mathrm{P}$ & $P$ & $P$ & - & $P$ & - & $P$ & - \\
\hline F.S. & $\mathrm{H}$ & 9,4 & $\bar{M}$ & - & $\mathrm{P}$ & - & - & - & $\mathrm{P}$ & $\mathrm{P}$ & $\mathrm{P}$ & $P$ & - & $\mathrm{P}$ & - & $P$ & - \\
\hline E.C.L. & $\mathrm{H}$ & 9,8 & $\mathrm{~F}$ & - & $\mathrm{P}$ & - & - & - & $\mathrm{P}$ & $\mathrm{P}$ & $\mathrm{P}$ & $P$ & - & - & - & $\mathrm{P}$ & - \\
\hline R.F.E. & $\mathrm{H}$ & 9,2 & $\bar{M}$ & $\mathrm{P}$ & $\mathrm{P}$ & - & $\mathrm{P}$ & - & $\mathrm{P}$ & $\mathrm{P}$ & $\mathrm{P}$ & $P$ & - & $\mathrm{P}$ & - & $P$ & - \\
\hline S.T.G. & $\overline{\mathrm{H}}$ & 9,5 & $\bar{M}$ & - & $\mathrm{P}$ & - & - & - & $\mathrm{P}$ & $\mathrm{P}$ & $\mathrm{P}$ & $P$ & - & - & - & $P$ & - \\
\hline R.F.B. & $\mathrm{H}$ & 9,5 & $\mathrm{M}$ & - & $\mathrm{P}$ & - & - & - & $\mathrm{P}$ & $\mathrm{P}$ & $\mathrm{P}$ & $P$ & - & $\mathrm{P}$ & $\mathrm{P}$ & $P$ & - \\
\hline R.R.D. & $\overline{\mathrm{H}}$ & 9,7 & $\bar{M}$ & - & $P$ & $\mathrm{P}$ & $\mathrm{P}$ & - & $\mathrm{P}$ & $P$ & $P$ & $P$ & - & $\mathrm{P}$ & - & $P$ & - \\
\hline J.A.R.C.M. & $\mathrm{H}$ & 9,8 & $\mathrm{M}$ & - & $\mathrm{P}$ & - & - & - & $\mathrm{P}$ & $\mathrm{P}$ & $\mathrm{P}$ & $P$ & - & - & - & $\mathrm{P}$ & - \\
\hline R.O.B.A. & $\mathrm{H}$ & 9,4 & $\bar{M}$ & - & $\mathrm{P}$ & - & - & - & $\mathrm{P}$ & $\mathrm{P}$ & $\mathrm{P}$ & $P$ & - & - & - & $P$ & - \\
\hline C.F.Z.S. & $\mathrm{H}$ & 9,0 & $\mathrm{~F}$ & - & $\mathrm{P}$ & - & - & - & $\mathrm{P}$ & $\mathrm{P}$ & $P$ & $P$ & - & - & - & $P$ & - \\
\hline M.P.P. & $\mathrm{H}$ & 9,5 & $\mathrm{~F}$ & - & $\mathrm{P}$ & - & - & - & $\mathrm{P}$ & $\mathrm{P}$ & $P$ & $P$ & - & - & - & $P$ & - \\
\hline T.F.D. & $\mathrm{H}$ & 9,0 & $\bar{M}$ & - & $\mathrm{P}$ & - & - & - & $\mathrm{P}$ & $\mathrm{P}$ & $\mathrm{P}$ & $P$ & - & - & - & $\mathrm{P}$ & - \\
\hline C.L.C. & $\mathrm{H}$ & 9,3 & $\mathrm{~F}$ & - & $\mathrm{P}$ & $P$ & $\mathrm{P}$ & - & $\mathrm{P}$ & $\mathrm{P}$ & $\mathrm{P}$ & $P$ & - & - & $\mathrm{P}$ & $\mathrm{P}$ & - \\
\hline T.S.N.J. & $\mathrm{H}$ & 9,5 & $\bar{M}$ & - & $\mathrm{P}$ & - & - & - & $\mathrm{P}$ & $\mathrm{P}$ & $\mathrm{P}$ & $\mathrm{P}$ & - & - & - & $\mathrm{P}$ & - \\
\hline O.C.C. & $\mathrm{H}$ & 9,2 & $M$ & - & $\mathrm{P}$ & - & - & - & $\mathrm{P}$ & $\mathrm{P}$ & $\mathrm{P}$ & $\mathrm{P}$ & - & - & - & $\mathrm{P}$ & - \\
\hline J.A.A.C. & $\overline{\mathrm{H}}$ & 9,8 & $\mathrm{M}$ & - & $P$ & - & - & - & $P$ & $\mathrm{P}$ & $\mathrm{P}$ & $P$ & - & - & - & $\mathrm{P}$ & - \\
\hline P.B.B.M. & $\mathrm{H}$ & 9,7 & $\mathrm{~F}$ & - & $\mathrm{P}$ & - & - & - & $\mathrm{P}$ & $\mathrm{P}$ & $\mathrm{P}$ & $\mathrm{P}$ & - & - & - & $\mathrm{P}$ & - \\
\hline M.H.T. & $\mathrm{H}$ & 9,2 & $\mathrm{~F}$ & - & $\mathrm{P}$ & - & - & - & $\mathrm{P}$ & $\mathrm{P}$ & $\mathrm{P}$ & $\mathrm{P}$ & - & - & - & $\mathrm{P}$ & - \\
\hline F.B. & $\overline{\mathrm{H}}$ & 9,5 & $\mathrm{~F}$ & - & $\mathrm{P}$ & - & $\mathrm{P}$ & - & $\mathrm{P}$ & $\mathrm{P}$ & $\mathrm{P}$ & $\mathrm{P}$ & - & $\mathrm{P}$ & $\mathrm{P}$ & $\mathrm{P}$ & - \\
\hline A.B.S.M. & $\mathrm{H}$ & 9,8 & $\mathrm{~F}$ & - & $\mathrm{P}$ & - & - & - & $\mathrm{P}$ & $\mathrm{P}$ & $\mathrm{P}$ & $\mathrm{P}$ & - & - & - & $\mathrm{P}$ & - \\
\hline C.B.J. & $\mathrm{H}$ & 9,5 & $\mathrm{~F}$ & - & $\mathrm{P}$ & - & - & - & $\mathrm{P}$ & $\mathrm{P}$ & $\mathrm{P}$ & $\mathrm{P}$ & - & - & - & $\mathrm{P}$ & - \\
\hline D.E.H. & $\mathrm{H}$ & 9,7 & $\mathrm{~F}$ & - & $\mathrm{P}$ & - & $\mathrm{P}$ & $\mathrm{P}$ & $\mathrm{P}$ & $\mathrm{P}$ & $\mathrm{P}$ & $\mathrm{P}$ & $\mathrm{P}$ & $\mathrm{P}$ & - & $\mathrm{P}$ & - \\
\hline D.A.M. & $\overline{\mathrm{H}}$ & 9,6 & $\bar{M}$ & - & $\mathrm{P}$ & - & - & - & $\mathrm{P}$ & $\mathrm{P}$ & $\mathrm{P}$ & $P$ & - & - & - & $\mathrm{P}$ & - \\
\hline M.L.P. & $\mathrm{H}$ & 9,0 & $\mathrm{~F}$ & - & $P$ & - & - & - & $\mathrm{P}$ & $\mathrm{P}$ & $P$ & $P$ & - & - & - & $\mathrm{P}$ & - \\
\hline L.B. & $\mathrm{H}$ & 9,0 & $\mathrm{~F}$ & - & $\mathrm{P}$ & - & - & - & $\mathrm{P}$ & $\mathrm{P}$ & $\mathrm{P}$ & $\mathrm{P}$ & - & - & - & $P$ & - \\
\hline P.S.E. & $\mathrm{H}$ & 9,4 & $F$ & - & $\mathrm{P}$ & - & - & - & $\mathrm{P}$ & $\mathrm{P}$ & $P$ & $\mathrm{P}$ & - & - & - & $\mathrm{P}$ & - \\
\hline J.R.N. & $\mathrm{H}$ & 9,8 & $\bar{M}$ & - & $P$ & - & - & - & $\mathrm{P}$ & $P$ & $P$ & $P$ & - & - & - & $P$ & - \\
\hline
\end{tabular}


Tabela A-13

\begin{tabular}{|c|c|c|c|c|c|c|c|c|c|c|c|c|c|c|c|c|c|}
\hline Nome & Grupo & Idade & Gênero & 37 & 36 & 35 & 34 & 33 & 32 & 31 & 41 & 42 & 43 & 44 & 45 & 46 & 47 \\
\hline A.P.T. & V & 9,7 & $\mathrm{~F}$ & - & $\mathrm{P}$ & - & $\mathrm{P}$ & $\mathrm{P}$ & $\mathrm{P}$ & $\mathrm{P}$ & $\mathrm{P}$ & $\mathrm{P}$ & $\mathrm{P}$ & $\mathrm{P}$ & - & $\mathrm{P}$ & - \\
\hline J.M.R.M. & $\bar{V}$ & 9,9 & $\bar{M}$ & - & $\mathrm{P}$ & - & - & $P$ & $\mathrm{P}$ & $P$ & $P$ & $\mathrm{P}$ & $\mathrm{P}$ & $\mathrm{P}$ & - & $\mathrm{P}$ & - \\
\hline T.S.C. & $\mathrm{V}$ & 9,3 & $\mathrm{M}$ & - & $\mathrm{P}$ & - & - & - & $\mathrm{P}$ & $P$ & $\mathrm{P}$ & $\mathrm{P}$ & - & - & - & $\mathrm{P}$ & - \\
\hline T.V.S. & $\mathrm{V}$ & 9,0 & $M$ & - & $\mathrm{P}$ & - & $\mathrm{P}$ & - & $\mathrm{P}$ & $P$ & $P$ & $\mathrm{P}$ & - & $\mathrm{P}$ & - & $\mathrm{P}$ & - \\
\hline R.A.A. & $\mathrm{V}$ & 9,6 & $\bar{M}$ & - & $\mathrm{P}$ & - & - & - & $\mathrm{P}$ & $P$ & $P$ & $\mathrm{P}$ & - & - & - & $\mathrm{P}$ & - \\
\hline D.F.D. & $\mathrm{V}$ & 9,0 & $\bar{M}$ & - & $\mathrm{P}$ & - & - & - & $\mathrm{P}$ & $P$ & $P$ & $\mathrm{P}$ & - & - & - & $\mathrm{P}$ & - \\
\hline A.C.M. & $\mathrm{V}$ & 9,6 & $\mathrm{~F}$ & - & $\mathrm{P}$ & - & $\mathrm{P}$ & $\mathrm{P}$ & $\mathrm{P}$ & $\mathrm{P}$ & $P$ & $\mathrm{P}$ & $\mathrm{P}$ & - & $P$ & $\mathrm{P}$ & - \\
\hline E.P.B. & V & 9,8 & $\mathrm{~F}$ & - & $P$ & - & $\mathrm{P}$ & $\mathrm{P}$ & $\mathrm{P}$ & $P$ & $P$ & $\mathrm{P}$ & $\mathrm{P}$ & - & - & $P$ & - \\
\hline E.C.M. & V & 9,9 & $\mathrm{~F}$ & - & $P$ & - & - & - & $\mathrm{P}$ & $P$ & $P$ & $P$ & - & $\mathrm{P}$ & - & $\mathrm{P}$ & - \\
\hline A.L.M. & $\mathrm{V}$ & 9,1 & $\mathrm{~F}$ & - & $\mathrm{P}$ & - & - & - & $\mathrm{P}$ & $\mathrm{P}$ & $P$ & $\mathrm{P}$ & - & $\mathrm{P}$ & $P$ & $\mathrm{P}$ & - \\
\hline J.C.M.J. & V & 9,0 & $\mathrm{M}$ & - & $\mathrm{P}$ & - & - & - & - & $P$ & $P$ & $P$ & - & - & - & $\mathrm{P}$ & - \\
\hline A.F.G. & V & 9,5 & $\mathrm{M}$ & - & $\mathrm{P}$ & - & - & $\mathrm{P}$ & $P$ & $\mathrm{P}$ & $P$ & $\mathrm{P}$ & $\mathrm{P}$ & $P$ & - & $P$ & $\mathrm{P}$ \\
\hline M.A.P.T. & $\mathrm{V}$ & 9,1 & $\bar{M}$ & - & $P$ & - & - & - & $P$ & $P$ & $P$ & $\mathrm{P}$ & - & - & - & $P$ & - \\
\hline P.B.J. & V & 9,9 & $M$ & - & $P$ & - & $P$ & - & $\mathrm{P}$ & $P$ & $P$ & $P$ & - & $\mathrm{P}$ & - & $P$ & - \\
\hline R.G.M. & V & 9,2 & $\mathrm{M}$ & - & $P$ & - & - & $\mathrm{P}$ & $\mathrm{P}$ & $P$ & $P$ & $P$ & $\mathrm{P}$ & $P$ & - & $P$ & - \\
\hline T.C.C.C. & $\mathrm{V}$ & 9,5 & $\mathrm{~F}$ & - & $P$ & - & - & $P$ & $\mathrm{P}$ & $\mathrm{P}$ & $P$ & $\mathrm{P}$ & $\mathrm{P}$ & $\mathrm{P}$ & $\mathrm{P}$ & $P$ & - \\
\hline M.Q.B. & V & 9,5 & $M$ & - & $\mathrm{P}$ & - & $\mathrm{P}$ & $\mathrm{P}$ & $\mathrm{P}$ & $\mathrm{P}$ & $P$ & $\mathrm{P}$ & $\mathrm{P}$ & $\mathrm{P}$ & - & $P$ & $\mathrm{P}$ \\
\hline R.B.R. & V & 9,2 & $\mathrm{~F}$ & - & $\mathrm{P}$ & - & - & - & $\mathrm{P}$ & $P$ & $P$ & $\mathrm{P}$ & - & - & - & $\mathrm{P}$ & - \\
\hline F.B.A. & V & 9,4 & $\mathrm{~F}$ & - & $\mathrm{P}$ & - & - & $\mathrm{P}$ & $\mathrm{P}$ & $P$ & $P$ & $\mathrm{P}$ & $\mathrm{P}$ & - & - & $\mathrm{P}$ & - \\
\hline M.F.G. & $\mathrm{V}$ & 9,0 & $\mathrm{~F}$ & - & $P$ & - & - & - & $\mathrm{P}$ & $\mathrm{P}$ & $\mathrm{P}$ & $\mathrm{P}$ & - & - & - & $\mathrm{P}$ & - \\
\hline S.D. & V & 9,9 & $\mathrm{~F}$ & - & $\mathrm{P}$ & - & $\mathrm{P}$ & $P$ & $\mathrm{P}$ & $\mathrm{P}$ & $P$ & $\mathrm{P}$ & $\mathrm{P}$ & $\mathrm{P}$ & - & $P$ & - \\
\hline F.B.R. & $\mathrm{V}$ & 9,0 & $\mathrm{~F}$ & - & $\mathrm{P}$ & - & - & - & $\mathrm{P}$ & $P$ & $P$ & $\mathrm{P}$ & - & - & - & $P$ & - \\
\hline E.F.Z. & $\overline{\mathrm{V}}$ & 9,4 & $\mathrm{~F}$ & - & $P$ & - & - & - & $\mathrm{P}$ & $\mathrm{P}$ & $\mathrm{P}$ & $\mathrm{P}$ & - & - & - & $\bar{P}$ & - \\
\hline A.R.F. & V & 9,9 & $\bar{M}$ & - & $P$ & - & $P$ & $P$ & $\mathrm{P}$ & 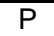 & $P$ & $P$ & $\mathrm{P}$ & $P$ & - & $P$ & - \\
\hline M.G.T. & $\mathrm{V}$ & 9,5 & $\bar{M}$ & - & $\mathrm{P}$ & $\mathrm{P}$ & $\mathrm{P}$ & $\mathrm{P}$ & $\mathrm{P}$ & $\mathrm{P}$ & $P$ & $\mathrm{P}$ & $\mathrm{P}$ & $\mathrm{P}$ & $\mathrm{P}$ & $P$ & - \\
\hline C.V.E. & $\mathrm{V}$ & 9,4 & $F$ & $\mathrm{P}$ & $P$ & - & $\mathrm{P}$ & $\mathrm{P}$ & $\mathrm{P}$ & $P$ & $P$ & $\mathrm{P}$ & $\mathrm{P}$ & $\mathrm{P}$ & - & $P$ & $\mathrm{P}$ \\
\hline R.T.D.G. & $\mathrm{V}$ & 9,7 & $\bar{M}$ & - & $\mathrm{P}$ & - & - & - & $\mathrm{P}$ & $\mathrm{P}$ & $P$ & $\mathrm{P}$ & - & - & - & $P$ & - \\
\hline R.Q. & V & 9,8 & $M$ & - & $\mathrm{P}$ & - & $P$ & - & $\mathrm{P}$ & $\mathrm{P}$ & $\mathrm{P}$ & $\mathrm{P}$ & - & - & - & $\mathrm{P}$ & - \\
\hline E.L.C.S. & V & 9,9 & $\bar{M}$ & - & $\mathrm{P}$ & $\mathrm{P}$ & - & - & $\mathrm{P}$ & $\mathrm{P}$ & $P$ & $\mathrm{P}$ & $\mathrm{P}$ & $\mathrm{P}$ & - & $P$ & - \\
\hline H.J.S.S. & V & 9,6 & $\bar{M}$ & - & $\mathrm{P}$ & - & - & - & $\mathrm{P}$ & $\mathrm{P}$ & $P$ & $\mathrm{P}$ & - & - & - & $\mathrm{P}$ & - \\
\hline C.M.T. & $\mathrm{H}$ & 9,9 & $\bar{M}$ & - & $\mathrm{P}$ & - & - & - & $\mathrm{P}$ & $\mathrm{P}$ & $P$ & $\mathrm{P}$ & $\mathrm{P}$ & - & - & $\mathrm{P}$ & - \\
\hline V.M.A.C. & $\mathrm{H}$ & 9,8 & $\mathrm{~F}$ & - & $P$ & $\mathrm{P}$ & $\mathrm{P}$ & $\mathrm{P}$ & $\mathrm{P}$ & $\mathrm{P}$ & $\mathrm{P}$ & $\mathrm{P}$ & $\mathrm{P}$ & $\mathrm{P}$ & $\mathrm{P}$ & $\mathrm{P}$ & $P$ \\
\hline R.P.F. & $\mathrm{H}$ & 9,7 & $\bar{M}$ & - & $P$ & - & - & - & $\mathrm{P}$ & $\mathrm{P}$ & $P$ & $P$ & - & - & - & $\mathrm{P}$ & - \\
\hline A.C.D. & $\mathrm{H}$ & 9,5 & $\mathrm{~F}$ & $\mathrm{P}$ & $P$ & $P$ & $P$ & $P$ & $P$ & $P$ & $P$ & $P$ & $\mathrm{P}$ & $P$ & $P$ & $P$ & $P$ \\
\hline F.S. & $\mathrm{H}$ & 9,4 & $\bar{M}$ & - & $\mathrm{P}$ & - & - & - & $\mathrm{P}$ & $P$ & $P$ & $\mathrm{P}$ & - & - & - & $P$ & - \\
\hline E.C.L. & $\mathrm{H}$ & 9,8 & $\mathrm{~F}$ & - & $\mathrm{P}$ & - & - & $\mathrm{P}$ & $\mathrm{P}$ & $\mathrm{P}$ & $P$ & $\mathrm{P}$ & $\mathrm{P}$ & - & - & $\mathrm{P}$ & - \\
\hline R.F.E. & $\mathrm{H}$ & 9,2 & $\bar{M}$ & $\mathrm{P}$ & $\mathrm{P}$ & - & $\mathrm{P}$ & $\mathrm{P}$ & $\mathrm{P}$ & $\mathrm{P}$ & $\mathrm{P}$ & $\mathrm{P}$ & $\mathrm{P}$ & $\mathrm{P}$ & $\mathrm{P}$ & $\mathrm{P}$ & $\mathrm{P}$ \\
\hline S.T.G. & $\overline{\mathrm{H}}$ & 9,5 & $\bar{M}$ & - & $\mathrm{P}$ & - & - & - & $\mathrm{P}$ & $\mathrm{P}$ & $P$ & $\mathrm{P}$ & - & - & - & $P$ & - \\
\hline R.F.B. & $\overline{\mathrm{H}}$ & 9,5 & $\bar{M}$ & - & $\mathrm{P}$ & - & - & - & $\mathrm{P}$ & $P$ & $P$ & $\mathrm{P}$ & - & - & - & $\mathrm{P}$ & - \\
\hline R.R.D. & $\overline{\mathrm{H}}$ & 9,7 & $\bar{M}$ & - & $P$ & - & - & - & $\mathrm{P}$ & $P$ & $\mathrm{P}$ & $\mathrm{P}$ & - & - & - & $P$ & - \\
\hline J.A.R.C.M. & $\mathrm{H}$ & 9,8 & $\mathrm{M}$ & - & $\mathrm{P}$ & - & - & - & $\mathrm{P}$ & $\mathrm{P}$ & $P$ & $\mathrm{P}$ & - & - & - & $\mathrm{P}$ & - \\
\hline R.O.B.A. & $\mathrm{H}$ & 9,4 & $\bar{M}$ & - & $P$ & - & - & - & $\mathrm{P}$ & $P$ & $P$ & $\mathrm{P}$ & - & - & - & $\mathrm{P}$ & - \\
\hline C.F.Z.S. & $\mathrm{H}$ & 9,0 & $\mathrm{~F}$ & - & $P$ & - & - & - & $\mathrm{P}$ & $\mathrm{P}$ & $\mathrm{P}$ & $\mathrm{P}$ & - & - & - & $P$ & - \\
\hline M.P.P. & $\mathrm{H}$ & 9,5 & $\mathrm{~F}$ & - & $\mathrm{P}$ & - & - & - & $\mathrm{P}$ & $P$ & $P$ & $\mathrm{P}$ & - & - & - & $\mathrm{P}$ & - \\
\hline T.F.D. & $\mathrm{H}$ & 9,0 & $\bar{M}$ & - & $\mathrm{P}$ & - & - & $\mathrm{P}$ & $\mathrm{P}$ & $P$ & $P$ & $\mathrm{P}$ & - & - & - & $\mathrm{P}$ & - \\
\hline C.L.C. & $\mathrm{H}$ & 9,3 & $\mathrm{~F}$ & - & $\mathrm{P}$ & $\mathrm{P}$ & - & $\mathrm{P}$ & $\mathrm{P}$ & $\mathrm{P}$ & $P$ & $\mathrm{P}$ & $\mathrm{P}$ & - & $\mathrm{P}$ & $\mathrm{P}$ & - \\
\hline T.S.N.J. & $\mathrm{H}$ & 9,5 & $\bar{M}$ & - & $\mathrm{P}$ & - & - & $\mathrm{P}$ & $\mathrm{P}$ & $\mathrm{P}$ & $\mathrm{P}$ & $\mathrm{P}$ & - & - & - & $\mathrm{P}$ & - \\
\hline O.C.C. & $\mathrm{H}$ & 9,2 & $M$ & - & $\mathrm{P}$ & - & - & - & $\mathrm{P}$ & $\mathrm{P}$ & $P$ & $\mathrm{P}$ & - & - & - & $\mathrm{P}$ & - \\
\hline J.A.A.C. & $\overline{\mathrm{H}}$ & 9,8 & $\mathrm{M}$ & - & $\mathrm{P}$ & - & - & - & $P$ & $\mathrm{P}$ & $P$ & $\mathrm{P}$ & - & - & - & $\mathrm{P}$ & - \\
\hline P.B.B.M. & $\mathrm{H}$ & 9,7 & $\mathrm{~F}$ & - & $\mathrm{P}$ & - & - & - & $\mathrm{P}$ & $\mathrm{P}$ & $P$ & $\mathrm{P}$ & $\mathrm{P}$ & - & - & $\mathrm{P}$ & - \\
\hline M.H.T. & $\mathrm{H}$ & 9,2 & $\mathrm{~F}$ & - & $\mathrm{P}$ & - & - & - & $\mathrm{P}$ & $\mathrm{P}$ & $\mathrm{P}$ & $\mathrm{P}$ & - & - & - & $\mathrm{P}$ & - \\
\hline F.B. & $\overline{\mathrm{H}}$ & 9,5 & $\mathrm{~F}$ & - & $\mathrm{P}$ & - & - & - & $\mathrm{P}$ & $\mathrm{P}$ & $\mathrm{P}$ & $\mathrm{P}$ & $\mathrm{P}$ & - & - & $\mathrm{P}$ & - \\
\hline A.B.S.M. & $\mathrm{H}$ & 9,8 & $\mathrm{~F}$ & - & $\mathrm{P}$ & - & - & - & $\mathrm{P}$ & $\mathrm{P}$ & $\mathrm{P}$ & $\mathrm{P}$ & - & - & - & $\mathrm{P}$ & - \\
\hline C.B.J. & $\mathrm{H}$ & 9,5 & $\mathrm{~F}$ & - & $\mathrm{P}$ & - & - & - & $\mathrm{P}$ & $\mathrm{P}$ & $\mathrm{P}$ & $\mathrm{P}$ & - & - & - & $\mathrm{P}$ & - \\
\hline D.E.H. & $\mathrm{H}$ & 9,7 & $\mathrm{~F}$ & - & $\mathrm{P}$ & $\mathrm{P}$ & $\mathrm{P}$ & $\mathrm{P}$ & $\mathrm{P}$ & $\mathrm{P}$ & $\mathrm{P}$ & $\mathrm{P}$ & $\mathrm{P}$ & $\mathrm{P}$ & $\mathrm{P}$ & $\mathrm{P}$ & - \\
\hline D.A.M. & $\overline{\mathrm{H}}$ & 9,6 & $\bar{M}$ & - & $P$ & - & - & $P$ & $P$ & $\mathrm{P}$ & $P$ & $P$ & - & $P$ & - & $P$ & - \\
\hline M.L.P. & $\mathrm{H}$ & 9,0 & $\mathrm{~F}$ & - & $\mathrm{P}$ & - & - & $P$ & $\mathrm{P}$ & $P$ & $P$ & $P$ & $P$ & $P$ & - & $\mathrm{P}$ & - \\
\hline L.B. & $\mathrm{H}$ & 9,0 & $\mathrm{~F}$ & - & $P$ & - & - & $\mathrm{P}$ & $\mathrm{P}$ & $\mathrm{P}$ & $P$ & $\mathrm{P}$ & $\mathrm{P}$ & $P$ & $\mathrm{P}$ & $P$ & - \\
\hline P.S.E. & $\mathrm{H}$ & 9,4 & $F$ & - & $\mathrm{P}$ & - & - & - & $\mathrm{P}$ & $P$ & $P$ & $P$ & - & $\mathrm{P}$ & - & $\mathrm{P}$ & - \\
\hline J.R.N. & $\mathrm{H}$ & 9,8 & $\bar{M}$ & - & $P$ & - & $\mathrm{P}$ & - & $\mathrm{P}$ & $P$ & $\mathrm{P}$ & $\mathrm{P}$ & - & - & - & $P$ & - \\
\hline
\end{tabular}


Tabela A-14

\begin{tabular}{|c|c|c|c|c|c|c|c|c|c|c|c|c|c|c|c|c|c|}
\hline Nome & Grupo & Idade & Gênero & 17 & 16 & 15 & 14 & 13 & 12 & 11 & 21 & 22 & 23 & 24 & 25 & 26 & 27 \\
\hline A.P.T. & V & 10,6 & $\mathrm{~F}$ & - & $P$ & - & - & - & $\mathrm{P}$ & $\mathrm{P}$ & $\mathrm{P}$ & $\mathrm{P}$ & - & - & - & $\mathrm{P}$ & - \\
\hline J.M.R.M. & V & 10,9 & $\mathrm{M}$ & - & $\mathrm{P}$ & $\mathrm{P}$ & $\mathrm{P}$ & - & $\mathrm{P}$ & $\mathrm{P}$ & $\mathrm{P}$ & $P$ & - & $\mathrm{P}$ & $\mathrm{P}$ & $\mathrm{P}$ & - \\
\hline T.V.S. & $\mathrm{V}$ & 10,0 & $M$ & - & $P$ & - & - & - & $\mathrm{P}$ & $\mathrm{P}$ & $\mathrm{P}$ & $\mathrm{P}$ & - & $\mathrm{P}$ & $\mathrm{P}$ & $\mathrm{P}$ & - \\
\hline R.A.A. & V & 10,7 & $\mathrm{M}$ & - & $P$ & - & $\mathrm{P}$ & - & $\mathrm{P}$ & $\mathrm{P}$ & $\mathrm{P}$ & $\mathrm{P}$ & - & $\mathrm{P}$ & - & $\mathrm{P}$ & - \\
\hline D.F.D. & V & 10,0 & $\mathrm{M}$ & - & $P$ & - & $\mathrm{P}$ & - & $\mathrm{P}$ & $\mathrm{P}$ & $\mathrm{P}$ & $\mathrm{P}$ & - & $\mathrm{P}$ & - & $\mathrm{P}$ & - \\
\hline R.A.A.P.R. & $\mathrm{V}$ & 10,8 & $\mathrm{~F}$ & - & $\mathrm{P}$ & - & - & - & $\mathrm{P}$ & $\mathrm{P}$ & $\mathrm{P}$ & $\mathrm{P}$ & - & - & - & $\mathrm{P}$ & - \\
\hline A.C.M. & $\mathrm{V}$ & 10,6 & $\mathrm{~F}$ & $\mathrm{P}$ & $P$ & $\mathrm{P}$ & $\mathrm{P}$ & $\mathrm{P}$ & $\mathrm{P}$ & $\mathrm{P}$ & $\mathrm{P}$ & $\mathrm{P}$ & $\mathrm{P}$ & $\mathrm{P}$ & $\mathrm{P}$ & $\mathrm{P}$ & $\mathrm{P}$ \\
\hline E.P.B. & V & 10,9 & $\mathrm{~F}$ & - & $P$ & $\mathrm{P}$ & $\mathrm{P}$ & $\mathrm{P}$ & $\mathrm{P}$ & $\mathrm{P}$ & $P$ & $\mathrm{P}$ & - & $\mathrm{P}$ & $\mathrm{P}$ & $P$ & - \\
\hline P.S.P.C. & $\bar{V}$ & 10,5 & $M$ & - & $\mathrm{P}$ & - & $\mathrm{P}$ & - & $\mathrm{P}$ & $\mathrm{P}$ & $\mathrm{P}$ & $\mathrm{P}$ & - & $\mathrm{P}$ & $\mathrm{P}$ & $\mathrm{P}$ & - \\
\hline E.C.M. & $\mathrm{V}$ & 10,8 & $\mathrm{~F}$ & - & $P$ & $\mathrm{P}$ & $\mathrm{P}$ & - & $\mathrm{P}$ & $\mathrm{P}$ & $\mathrm{P}$ & $\mathrm{P}$ & - & - & - & $\mathrm{P}$ & - \\
\hline A.L.M. & $\mathrm{V}$ & 10,2 & $\mathrm{~F}$ & - & $\mathrm{P}$ & $\mathrm{P}$ & $\mathrm{P}$ & - & $\mathrm{P}$ & $\mathrm{P}$ & $\mathrm{P}$ & $\mathrm{P}$ & $\mathrm{P}$ & $\mathrm{P}$ & $\mathrm{P}$ & $\mathrm{P}$ & - \\
\hline J.C.M.J. & $\mathrm{V}$ & 10,0 & $\mathrm{M}$ & - & $\mathrm{P}$ & - & - & - & $\mathrm{P}$ & $\mathrm{P}$ & $\mathrm{P}$ & $\mathrm{P}$ & - & - & $\mathrm{P}$ & $\mathrm{P}$ & - \\
\hline A.F.G. & $\mathrm{V}$ & 10,5 & $M$ & - & $\mathrm{P}$ & $\mathrm{P}$ & $\mathrm{P}$ & $\mathrm{P}$ & $\mathrm{P}$ & $\mathrm{P}$ & $\mathrm{P}$ & $\mathrm{P}$ & $\mathrm{P}$ & $\mathrm{P}$ & $\mathrm{P}$ & $\mathrm{P}$ & $\mathrm{P}$ \\
\hline M.A.P.T. & $\mathrm{V}$ & 10,2 & $\mathrm{M}$ & - & $\mathrm{P}$ & - & - & - & $\mathrm{P}$ & $\mathrm{P}$ & $\mathrm{P}$ & $\mathrm{P}$ & - & - & - & $\mathrm{P}$ & - \\
\hline P.B.J. & $\mathrm{V}$ & 10,9 & $M$ & - & $\mathrm{P}$ & $\mathrm{P}$ & $\mathrm{P}$ & - & $\mathrm{P}$ & $P$ & $\mathrm{P}$ & $\mathrm{P}$ & - & $P$ & $P$ & $\mathrm{P}$ & - \\
\hline R.G.M. & $\mathrm{V}$ & 10,1 & $\bar{M}$ & - & $\mathrm{P}$ & - & - & - & $\mathrm{P}$ & $\mathrm{P}$ & $\mathrm{P}$ & $\mathrm{P}$ & $\mathrm{P}$ & $\mathrm{P}$ & $\mathrm{P}$ & $\mathrm{P}$ & - \\
\hline T.C.C.C. & $\mathrm{V}$ & 10,5 & $\mathrm{~F}$ & - & $P$ & - & $\mathrm{P}$ & $\mathrm{P}$ & $\mathrm{P}$ & $\mathrm{P}$ & $\mathrm{P}$ & $\mathrm{P}$ & - & $\mathrm{P}$ & - & $\mathrm{P}$ & - \\
\hline M.Q.B. & $\mathrm{V}$ & 10,4 & $\bar{M}$ & - & $\mathrm{P}$ & $\mathrm{P}$ & $\mathrm{P}$ & $\mathrm{P}$ & $\mathrm{P}$ & $\mathrm{P}$ & $\mathrm{P}$ & $\mathrm{P}$ & $\mathrm{P}$ & $\mathrm{P}$ & $\mathrm{P}$ & $\mathrm{P}$ & - \\
\hline R.A.S.S. & $\mathrm{V}$ & 10,4 & $\mathrm{~F}$ & - & $\mathrm{P}$ & - & - & - & - & $\mathrm{P}$ & $\mathrm{P}$ & - & - & - & - & $\mathrm{P}$ & - \\
\hline R.B.R. & $\mathrm{V}$ & 10,2 & $F$ & - & $\mathrm{P}$ & - & $\mathrm{P}$ & $\mathrm{P}$ & $\mathrm{P}$ & $\mathrm{P}$ & $\mathrm{P}$ & $\mathrm{P}$ & - & $\mathrm{P}$ & - & $\mathrm{P}$ & - \\
\hline F.B.A. & $\mathrm{V}$ & 10,4 & $\mathrm{~F}$ & - & $\mathrm{P}$ & - & $\mathrm{P}$ & $\mathrm{P}$ & $\mathrm{P}$ & $\mathrm{P}$ & $\mathrm{P}$ & $\mathrm{P}$ & $\mathrm{P}$ & $P$ & - & $\mathrm{P}$ & - \\
\hline M.F.G. & $\mathrm{V}$ & 10,1 & $\mathrm{~F}$ & - & $P$ & - & $\mathrm{P}$ & - & $\mathrm{P}$ & $P$ & $\mathrm{P}$ & $\mathrm{P}$ & - & $\mathrm{P}$ & - & $\mathrm{P}$ & - \\
\hline E.F.Z. & $\mathrm{V}$ & 10,5 & $\mathrm{~F}$ & - & $P$ & $\mathrm{P}$ & $\mathrm{P}$ & - & $\mathrm{P}$ & $\mathrm{P}$ & $\mathrm{P}$ & $\mathrm{P}$ & - & - & - & $\mathrm{P}$ & - \\
\hline M.G.T. & $\mathrm{V}$ & 10,6 & $\bar{M}$ & $\mathrm{P}$ & $\mathrm{P}$ & $\mathrm{P}$ & $\mathrm{P}$ & $\mathrm{P}$ & $\mathrm{P}$ & $\mathrm{P}$ & $\mathrm{P}$ & $\mathrm{P}$ & $\mathrm{P}$ & $\mathrm{P}$ & $\mathrm{P}$ & $\mathrm{P}$ & $\mathrm{P}$ \\
\hline R.T.D.G. & $\mathrm{V}$ & 10,8 & $\bar{M}$ & - & $P$ & $P$ & - & - & $P$ & $P$ & $P$ & $\mathrm{P}$ & - & - & - & $P$ & - \\
\hline G.C.T.N. & $\mathrm{V}$ & 10,6 & $\bar{M}$ & - & $\mathrm{P}$ & - & - & - & $\mathrm{P}$ & $P$ & $\mathrm{P}$ & $\mathrm{P}$ & - & $P$ & - & $\mathrm{P}$ & - \\
\hline R.Q. & $\mathrm{V}$ & 10,7 & $M$ & - & $\mathrm{P}$ & $\mathrm{P}$ & $\mathrm{P}$ & - & $\mathrm{P}$ & $\mathrm{P}$ & $\mathrm{P}$ & $\mathrm{P}$ & - & $\mathrm{P}$ & - & $\mathrm{P}$ & - \\
\hline E.L.C.S. & $\mathrm{V}$ & 10,8 & $M$ & - & $P$ & $P$ & $\mathrm{P}$ & - & $P$ & $P$ & $\mathrm{P}$ & $P$ & - & $P$ & $P$ & $\mathrm{P}$ & - \\
\hline M.S. & $\mathrm{V}$ & 10,2 & $\mathrm{M}$ & - & $\mathrm{P}$ & - & $\mathrm{P}$ & - & $\mathrm{P}$ & $\mathrm{P}$ & $\mathrm{P}$ & $\mathrm{P}$ & $\mathrm{P}$ & $\mathrm{P}$ & $\mathrm{P}$ & $\mathrm{P}$ & - \\
\hline A.L.F. & $\mathrm{V}$ & 10,0 & $\bar{M}$ & - & $\mathrm{P}$ & - & - & - & $\mathrm{P}$ & $\mathrm{P}$ & $\mathrm{P}$ & $\mathrm{P}$ & - & - & - & $\mathrm{P}$ & - \\
\hline V.M.A.C. & $\overline{\mathrm{H}}$ & 10,6 & $\mathrm{~F}$ & - & $\mathrm{P}$ & $\mathrm{P}$ & $\mathrm{P}$ & $\mathrm{P}$ & $\mathrm{P}$ & $P$ & $\mathrm{P}$ & $\mathrm{P}$ & $P$ & $P$ & $\mathrm{P}$ & $\mathrm{P}$ & - \\
\hline R.P.F. & $\mathrm{H}$ & 10,6 & $\mathrm{M}$ & - & $\mathrm{P}$ & - & $\mathrm{P}$ & - & $\mathrm{P}$ & $\mathrm{P}$ & $\mathrm{P}$ & $\mathrm{P}$ & - & $P$ & - & $\mathrm{P}$ & - \\
\hline A.C.D. & $\mathrm{H}$ & 10,5 & $F$ & $\mathrm{P}$ & $P$ & $P$ & $\mathrm{P}$ & $\mathrm{P}$ & $\mathrm{P}$ & $P$ & $\mathrm{P}$ & $\mathrm{P}$ & $\mathrm{P}$ & $P$ & $P$ & $\mathrm{P}$ & $\mathrm{P}$ \\
\hline F.S. & $\mathrm{H}$ & 10,3 & $M$ & - & $\mathrm{P}$ & $P$ & $P$ & - & $P$ & $P$ & $P$ & $P$ & - & $\mathrm{P}$ & - & $P$ & - \\
\hline E.C.L. & $\overline{\mathrm{H}}$ & 10,7 & $\mathrm{~F}$ & $P$ & $P$ & - & $P$ & $P$ & $\mathrm{P}$ & $P$ & $P$ & $P$ & $P$ & $P$ & - & $P$ & $P$ \\
\hline R.F.E. & $\mathrm{H}$ & 10,3 & $M$ & $\mathrm{P}$ & $\mathrm{P}$ & $\mathrm{P}$ & $\mathrm{P}$ & $\mathrm{P}$ & $\mathrm{P}$ & $\mathrm{P}$ & $\mathrm{P}$ & $\mathrm{P}$ & $\mathrm{P}$ & $P$ & $\mathrm{P}$ & $\mathrm{P}$ & $\mathrm{P}$ \\
\hline S.T.G. & $\mathrm{H}$ & 10,4 & $\bar{M}$ & - & $\mathrm{P}$ & - & - & - & $\mathrm{P}$ & $\mathrm{P}$ & $\mathrm{P}$ & $\mathrm{P}$ & - & - & - & $\mathrm{P}$ & - \\
\hline R.F.B. & $\mathrm{H}$ & 10,7 & $\bar{M}$ & - & $P$ & - & $P$ & - & $P$ & $P$ & $P$ & $P$ & - & $P$ & $P$ & $P$ & - \\
\hline R.R.D. & $\mathrm{H}$ & 10,7 & $\bar{M}$ & - & $\mathrm{P}$ & $\mathrm{P}$ & $\mathrm{P}$ & - & $\mathrm{P}$ & $P$ & $\mathrm{P}$ & $\mathrm{P}$ & - & $P$ & $\mathrm{P}$ & $\mathrm{P}$ & - \\
\hline J.A.R.C.M. & $\mathrm{H}$ & 10,9 & $\bar{M}$ & - & $\mathrm{P}$ & - & - & - & $\mathrm{P}$ & $\mathrm{P}$ & $\mathrm{P}$ & $\mathrm{P}$ & - & - & - & $\mathrm{P}$ & - \\
\hline B.M.L. & $\mathrm{H}$ & 10,2 & $M$ & - & $\mathrm{P}$ & - & $\mathrm{P}$ & - & $\mathrm{P}$ & $\mathrm{P}$ & $\mathrm{P}$ & $\mathrm{P}$ & - & $P$ & - & $\mathrm{P}$ & - \\
\hline R.O.B.A. & $\mathrm{H}$ & 10,5 & $\bar{M}$ & - & $\mathrm{P}$ & - & $P$ & $P$ & $\mathrm{P}$ & $P$ & $P$ & $\mathrm{P}$ & $P$ & $P$ & - & $\mathrm{P}$ & - \\
\hline C.F.Z.S. & $\mathrm{H}$ & 10,0 & $\mathrm{~F}$ & - & $\mathrm{P}$ & - & $\mathrm{P}$ & - & $\mathrm{P}$ & $\mathrm{P}$ & $\mathrm{P}$ & $\mathrm{P}$ & - & $\mathrm{P}$ & - & $\mathrm{P}$ & - \\
\hline M.P.P. & $\mathrm{H}$ & 10,5 & $\mathrm{~F}$ & - & $\mathrm{P}$ & - & - & - & $\mathrm{P}$ & $P$ & $\mathrm{P}$ & $\mathrm{P}$ & - & $\mathrm{P}$ & - & $\mathrm{P}$ & - \\
\hline T.F.D. & $\overline{\mathrm{H}}$ & 10,0 & $\bar{M}$ & - & $\mathrm{P}$ & $\mathrm{P}$ & $\mathrm{P}$ & - & $\mathrm{P}$ & $\mathrm{P}$ & $\mathrm{P}$ & $\mathrm{P}$ & $\mathrm{P}$ & $\mathrm{P}$ & - & $\mathrm{P}$ & - \\
\hline C.L.C. & $\mathrm{H}$ & 10,2 & $\mathrm{~F}$ & - & $\mathrm{P}$ & $\mathrm{P}$ & $\mathrm{P}$ & - & $\mathrm{P}$ & $\mathrm{P}$ & $\mathrm{P}$ & $\mathrm{P}$ & $P$ & $\mathrm{P}$ & $\mathrm{P}$ & $\mathrm{P}$ & - \\
\hline T.S.N.J. & $\mathrm{H}$ & 10,9 & $\bar{M}$ & - & $\mathrm{P}$ & - & $\mathrm{P}$ & $\mathrm{P}$ & $\mathrm{P}$ & $\mathrm{P}$ & $\mathrm{P}$ & $\mathrm{P}$ & $P$ & $\mathrm{P}$ & - & $\mathrm{P}$ & - \\
\hline O.C.C. & $\mathrm{H}$ & 10,1 & $M$ & - & $\mathrm{P}$ & - & $\mathrm{P}$ & - & $\mathrm{P}$ & $\mathrm{P}$ & $\mathrm{P}$ & $\mathrm{P}$ & - & - & - & $\mathrm{P}$ & - \\
\hline J.A.A.C. & $\mathrm{H}$ & 10,7 & $\bar{M}$ & - & $\mathrm{P}$ & - & - & - & $\mathrm{P}$ & $\mathrm{P}$ & $\mathrm{P}$ & $\mathrm{P}$ & - & - & - & $\mathrm{P}$ & - \\
\hline P.B.B.M. & $\mathrm{H}$ & 10,8 & $\mathrm{~F}$ & - & $\mathrm{P}$ & $\mathrm{P}$ & $\mathrm{P}$ & $\mathrm{P}$ & $\mathrm{P}$ & $\mathrm{P}$ & $\mathrm{P}$ & $\mathrm{P}$ & $\mathrm{P}$ & $\mathrm{P}$ & - & $\mathrm{P}$ & - \\
\hline M.H.T. & $\mathrm{H}$ & 10,0 & $F$ & - & $\mathrm{P}$ & - & - & - & $\mathrm{P}$ & $\mathrm{P}$ & $\mathrm{P}$ & $\mathrm{P}$ & - & - & - & $\mathrm{P}$ & - \\
\hline F.B. & $\mathrm{H}$ & 10,5 & $F$ & - & $\mathrm{P}$ & $\mathrm{P}$ & $\mathrm{P}$ & - & $\mathrm{P}$ & $\mathrm{P}$ & $\mathrm{P}$ & $\mathrm{P}$ & $\mathrm{P}$ & $\mathrm{P}$ & $\mathrm{P}$ & $\mathrm{P}$ & - \\
\hline C.B.J. & $\mathrm{H}$ & 10,5 & $F$ & $\mathrm{P}$ & $\mathrm{P}$ & - & - & - & $\mathrm{P}$ & $\mathrm{P}$ & $\mathrm{P}$ & $\mathrm{P}$ & - & - & - & $\mathrm{P}$ & $\mathrm{P}$ \\
\hline D.E.H. & $\mathrm{H}$ & 10,6 & $\mathrm{~F}$ & - & $\mathrm{P}$ & $\mathrm{P}$ & $\mathrm{P}$ & $\mathrm{P}$ & $\mathrm{P}$ & $\mathrm{P}$ & $\mathrm{P}$ & $\mathrm{P}$ & $P$ & $\mathrm{P}$ & $\mathrm{P}$ & $\mathrm{P}$ & - \\
\hline M.L.P. & $\mathrm{H}$ & 10,0 & $F$ & - & $\mathrm{P}$ & - & $\mathrm{P}$ & $\mathrm{P}$ & $\mathrm{P}$ & $P$ & $\mathrm{P}$ & $\mathrm{P}$ & $\mathrm{P}$ & $P$ & - & $\mathrm{P}$ & - \\
\hline L.B. & $\mathrm{H}$ & 10,8 & $\mathrm{~F}$ & $\mathrm{P}$ & $\mathrm{P}$ & $\mathrm{P}$ & $\mathrm{P}$ & $\mathrm{P}$ & $\mathrm{P}$ & $\mathrm{P}$ & $\mathrm{P}$ & $\mathrm{P}$ & $\mathrm{P}$ & $\mathrm{P}$ & $\mathrm{P}$ & $\mathrm{P}$ & $\mathrm{P}$ \\
\hline A.P.M.B. & $\mathrm{H}$ & 10,0 & $\mathrm{~F}$ & - & $P$ & - & $\mathrm{P}$ & $\mathrm{P}$ & $\mathrm{P}$ & $\mathrm{P}$ & $\mathrm{P}$ & $\mathrm{P}$ & $\mathrm{P}$ & $\mathrm{P}$ & - & $\mathrm{P}$ & - \\
\hline P.S.E. & $\mathrm{H}$ & 10,3 & $\mathrm{~F}$ & - & $\mathrm{P}$ & - & - & - & $\mathrm{P}$ & $\mathrm{P}$ & $\mathrm{P}$ & $\mathrm{P}$ & - & - & - & $\mathrm{P}$ & - \\
\hline J.R.N. & $\mathrm{H}$ & 10,9 & $M$ & - & $\mathrm{P}$ & - & - & - & $\mathrm{P}$ & $\mathrm{P}$ & $\mathrm{P}$ & $\mathrm{P}$ & - & - & - & $\mathrm{P}$ & - \\
\hline E.A. & $\mathrm{H}$ & 10,9 & $\bar{M}$ & $\mathrm{P}$ & $\mathrm{P}$ & $\mathrm{P}$ & $\mathrm{P}$ & - & $\mathrm{P}$ & $\mathrm{P}$ & $\mathrm{P}$ & $\mathrm{P}$ & - & - & - & $\mathrm{P}$ & - \\
\hline
\end{tabular}


Tabela A-15

\begin{tabular}{|c|c|c|c|c|c|c|c|c|c|c|c|c|c|c|c|c|c|}
\hline Nome & Grupo & Idade & Gênero & 37 & 36 & 35 & 34 & 33 & 32 & 31 & 41 & 42 & 43 & 44 & 45 & 46 & 47 \\
\hline A.P.T. & V & 10,6 & $\mathrm{~F}$ & - & $\mathrm{P}$ & - & $\mathrm{P}$ & $\mathrm{P}$ & $\mathrm{P}$ & $\mathrm{P}$ & $\mathrm{P}$ & $\mathrm{P}$ & $\mathrm{P}$ & $\mathrm{P}$ & - & $\mathrm{P}$ & - \\
\hline J.M.R.M. & $\mathrm{V}$ & 10,9 & $\mathrm{M}$ & - & $\mathrm{P}$ & - & $\mathrm{P}$ & $\mathrm{P}$ & $P$ & $\mathrm{P}$ & $\mathrm{P}$ & $\mathrm{P}$ & $\mathrm{P}$ & $\mathrm{P}$ & $P$ & $\mathrm{P}$ & $\mathrm{P}$ \\
\hline T.V.S. & $\mathrm{V}$ & 10,0 & $\mathrm{M}$ & - & $\mathrm{P}$ & - & $\mathrm{P}$ & $\mathrm{P}$ & $\mathrm{P}$ & $\mathrm{P}$ & $\mathrm{P}$ & $\mathrm{P}$ & $\mathrm{P}$ & $\mathrm{P}$ & - & $\mathrm{P}$ & - \\
\hline R.A.A. & $\mathrm{V}$ & 10,7 & $M$ & - & $\mathrm{P}$ & - & - & - & $\mathrm{P}$ & $\mathrm{P}$ & $\mathrm{P}$ & $\mathrm{P}$ & - & - & - & $\mathrm{P}$ & - \\
\hline D.F.D. & $\mathrm{V}$ & 10,0 & $\bar{M}$ & - & $\mathrm{P}$ & - & $\mathrm{P}$ & - & $\mathrm{P}$ & $\mathrm{P}$ & $\mathrm{P}$ & $\mathrm{P}$ & $\mathrm{P}$ & $\mathrm{P}$ & - & $\mathrm{P}$ & - \\
\hline R.A.A.P.R. & $\mathrm{V}$ & 10,8 & $F$ & - & $P$ & - & - & $\mathrm{P}$ & $\mathrm{P}$ & $P$ & $\mathrm{P}$ & $\mathrm{P}$ & $P$ & - & - & $\mathrm{P}$ & - \\
\hline A.C.M. & $\mathrm{V}$ & 10,6 & $\mathrm{~F}$ & $P$ & $\mathrm{P}$ & $P$ & $\mathrm{P}$ & $\mathrm{P}$ & $\mathrm{P}$ & $\mathrm{P}$ & $\mathrm{P}$ & $P$ & $\mathrm{P}$ & $\mathrm{P}$ & $P$ & $\mathrm{P}$ & $\mathrm{P}$ \\
\hline E.P.B. & $\mathrm{V}$ & 10,9 & $\mathrm{~F}$ & - & $P$ & $P$ & $\mathrm{P}$ & $P$ & $P$ & $P$ & $\mathrm{P}$ & $\mathrm{P}$ & $\mathrm{P}$ & $\mathrm{P}$ & $P$ & $\mathrm{P}$ & - \\
\hline P.S.P.C. & $\mathrm{V}$ & 10,5 & $\bar{M}$ & - & $\mathrm{P}$ & - & $P$ & $\mathrm{P}$ & $P$ & $\mathrm{P}$ & $\mathrm{P}$ & $P$ & $P$ & $P$ & - & $P$ & - \\
\hline E.C.M. & $\mathrm{V}$ & 10,8 & $\mathrm{~F}$ & - & $\mathrm{P}$ & - & $\mathrm{P}$ & $\mathrm{P}$ & $\mathrm{P}$ & $\mathrm{P}$ & $\mathrm{P}$ & $\mathrm{P}$ & $\mathrm{P}$ & $P$ & - & $\mathrm{P}$ & - \\
\hline A.L.M. & V & 10,2 & $\mathrm{~F}$ & - & $P$ & - & $P$ & $P$ & $\mathrm{P}$ & $P$ & $\mathrm{P}$ & $P$ & $P$ & $\mathrm{P}$ & $P$ & $\mathrm{P}$ & $\mathrm{P}$ \\
\hline J.C.M.J. & $\mathrm{V}$ & 10,0 & $\mathrm{M}$ & - & $P$ & - & - & - & $\mathrm{P}$ & $P$ & $\mathrm{P}$ & $P$ & - & - & - & $P$ & - \\
\hline A.F.G. & $\mathrm{V}$ & 10,5 & $\bar{M}$ & - & $P$ & $P$ & $P$ & $P$ & $P$ & $P$ & $P$ & $P$ & $P$ & $P$ & $P$ & $P$ & $\mathrm{P}$ \\
\hline M.A.P.T. & V & 10,2 & $\mathrm{M}$ & - & $\mathrm{P}$ & - & - & - & $P$ & $\mathrm{P}$ & $P$ & $P$ & - & - & $P$ & $\mathrm{P}$ & - \\
\hline P.B.J. & $\mathrm{V}$ & 10,9 & $\bar{M}$ & $P$ & $P$ & $P$ & $P$ & - & $P$ & $P$ & $\mathrm{P}$ & $P$ & - & $P$ & $P$ & $P$ & - \\
\hline R.G.M. & $\bar{V}$ & 10,1 & $\bar{M}$ & - & $\mathrm{P}$ & - & $P$ & $\mathrm{P}$ & $P$ & $\mathrm{P}$ & $\mathrm{P}$ & $\mathrm{P}$ & $\mathrm{P}$ & $\mathrm{P}$ & - & $\mathrm{P}$ & - \\
\hline T.C.C.C. & $\mathrm{V}$ & 10,5 & $\mathrm{~F}$ & - & $P$ & $P$ & $\mathrm{P}$ & $\mathrm{P}$ & $\mathrm{P}$ & $\mathrm{P}$ & $\mathrm{P}$ & $P$ & $\mathrm{P}$ & $\mathrm{P}$ & $P$ & $P$ & - \\
\hline M.Q.B. & $\mathrm{V}$ & 10,4 & $\mathrm{M}$ & $\mathrm{P}$ & $\mathrm{P}$ & $P$ & $\mathrm{P}$ & $\mathrm{P}$ & $\mathrm{P}$ & $\mathrm{P}$ & $\mathrm{P}$ & $\mathrm{P}$ & $\mathrm{P}$ & $\mathrm{P}$ & $P$ & $\mathrm{P}$ & $\mathrm{P}$ \\
\hline R.A.S.S. & $\mathrm{V}$ & 10,4 & $\mathrm{~F}$ & - & $\mathrm{P}$ & - & - & - & $\mathrm{P}$ & $\mathrm{P}$ & $\mathrm{P}$ & $\mathrm{P}$ & - & - & - & $\mathrm{P}$ & - \\
\hline R.B.R. & $\mathrm{V}$ & 10,2 & $\mathrm{~F}$ & - & $\mathrm{P}$ & - & $\mathrm{P}$ & $\mathrm{P}$ & $P$ & $\mathrm{P}$ & $\mathrm{P}$ & $\mathrm{P}$ & $\mathrm{P}$ & $\mathrm{P}$ & $\mathrm{P}$ & $\mathrm{P}$ & - \\
\hline F.B.A. & V & 10,4 & $\mathrm{~F}$ & - & $\mathrm{P}$ & - & $\mathrm{P}$ & $\mathrm{P}$ & $\mathrm{P}$ & $\mathrm{P}$ & $\mathrm{P}$ & $\mathrm{P}$ & $\mathrm{P}$ & $P$ & - & $\mathrm{P}$ & - \\
\hline M.F.G. & V & 10,1 & $\mathrm{~F}$ & - & $P$ & - & - & - & $\mathrm{P}$ & $P$ & $\mathrm{P}$ & $\mathrm{P}$ & - & - & - & $P$ & - \\
\hline E.F.Z. & $\mathrm{V}$ & 10,5 & $F$ & - & $\mathrm{P}$ & $P$ & $\mathrm{P}$ & $\mathrm{P}$ & $\mathrm{P}$ & $\mathrm{P}$ & $P$ & $\mathrm{P}$ & $\mathrm{P}$ & $\mathrm{P}$ & - & $\mathrm{P}$ & - \\
\hline M.G.T. & $\mathrm{V}$ & 10,6 & $\bar{M}$ & $P$ & $P$ & $P$ & $P$ & $\mathrm{P}$ & $P$ & $P$ & $P$ & $\mathrm{P}$ & $P$ & $P$ & $P$ & $P$ & $P$ \\
\hline R.T.D.G. & $\mathrm{V}$ & 10,8 & $\bar{M}$ & - & $\mathrm{P}$ & - & - & $\mathrm{P}$ & $\mathrm{P}$ & $\mathrm{P}$ & $\mathrm{P}$ & $\mathrm{P}$ & $\mathrm{P}$ & - & - & $\mathrm{P}$ & - \\
\hline G.C.T.N. & $\mathrm{V}$ & 10,6 & $\bar{M}$ & - & $\mathrm{P}$ & - & - & - & $\mathrm{P}$ & $\mathrm{P}$ & $\mathrm{P}$ & $\mathrm{P}$ & - & $\mathrm{P}$ & - & $\mathrm{P}$ & - \\
\hline R.Q. & $\mathrm{V}$ & 10,7 & $\bar{M}$ & - & $\mathrm{P}$ & - & $\mathrm{P}$ & $\mathrm{P}$ & $\mathrm{P}$ & $\mathrm{P}$ & $\mathrm{P}$ & $\mathrm{P}$ & - & - & - & $\mathrm{P}$ & - \\
\hline E.L.C.S. & $\mathrm{V}$ & 10,8 & $M$ & - & $\mathrm{P}$ & $P$ & $\mathrm{P}$ & $\mathrm{P}$ & $\mathrm{P}$ & $\mathrm{P}$ & $\mathrm{P}$ & $\mathrm{P}$ & $\mathrm{P}$ & $\mathrm{P}$ & $P$ & $\mathrm{P}$ & - \\
\hline M.S. & $\mathrm{V}$ & 10,2 & $\mathrm{M}$ & - & $\mathrm{P}$ & $P$ & $\mathrm{P}$ & - & $\mathrm{P}$ & $\mathrm{P}$ & $\mathrm{P}$ & $\mathrm{P}$ & $\mathrm{P}$ & $\mathrm{P}$ & - & $\mathrm{P}$ & - \\
\hline A.L.F. & $\mathrm{V}$ & 10,0 & $\bar{M}$ & - & $\mathrm{P}$ & - & $\mathrm{P}$ & - & $\mathrm{P}$ & $\mathrm{P}$ & $\mathrm{P}$ & $\mathrm{P}$ & - & - & - & $\mathrm{P}$ & - \\
\hline V.M.A.C. & $\mathrm{H}$ & 10,6 & $\mathrm{~F}$ & $\mathrm{P}$ & $\mathrm{P}$ & $P$ & $\mathrm{P}$ & $\mathrm{P}$ & $\mathrm{P}$ & $\mathrm{P}$ & $\mathrm{P}$ & $\mathrm{P}$ & $\mathrm{P}$ & $\mathrm{P}$ & $P$ & $\mathrm{P}$ & $\mathrm{P}$ \\
\hline R.P.F. & $\mathrm{H}$ & 10,6 & $\bar{M}$ & - & $\mathrm{P}$ & - & $\mathrm{P}$ & $\mathrm{P}$ & $\mathrm{P}$ & $P$ & $\mathrm{P}$ & $\mathrm{P}$ & $\mathrm{P}$ & $\mathrm{P}$ & - & $\mathrm{P}$ & - \\
\hline A.C.D. & $\mathrm{H}$ & 10,5 & $F$ & $\mathrm{P}$ & $P$ & $P$ & $P$ & $\mathrm{P}$ & $P$ & $P$ & $P$ & $\mathrm{P}$ & $P$ & $P$ & $P$ & $P$ & $P$ \\
\hline F.S. & $\mathrm{H}$ & 10,3 & $M$ & - & $P$ & - & - & - & $P$ & $P$ & $P$ & $P$ & - & - & - & $P$ & - \\
\hline E.C.L. & $\mathrm{H}$ & 10,7 & $\mathrm{~F}$ & $\mathrm{P}$ & $\mathrm{P}$ & $\mathrm{P}$ & $\mathrm{P}$ & $\mathrm{P}$ & $\mathrm{P}$ & $\mathrm{P}$ & $\mathrm{P}$ & $\mathrm{P}$ & $\mathrm{P}$ & $\mathrm{P}$ & $\mathrm{P}$ & $\mathrm{P}$ & $\mathrm{P}$ \\
\hline R.F.E. & $\mathrm{H}$ & 10,3 & $\mathrm{M}$ & $\mathrm{P}$ & $\mathrm{P}$ & $\mathrm{P}$ & $\mathrm{P}$ & $\mathrm{P}$ & $\mathrm{P}$ & $\mathrm{P}$ & $\mathrm{P}$ & $\mathrm{P}$ & $\mathrm{P}$ & $\mathrm{P}$ & $P$ & $\mathrm{P}$ & $\mathrm{P}$ \\
\hline S.T.G. & $\mathrm{H}$ & 10,4 & $\mathrm{M}$ & - & $\mathrm{P}$ & - & - & - & $\mathrm{P}$ & $\mathrm{P}$ & $P$ & $\mathrm{P}$ & - & - & - & $\mathrm{P}$ & - \\
\hline R.F.B. & $\mathrm{H}$ & 10,7 & $\mathrm{M}$ & - & $\mathrm{P}$ & - & $\mathrm{P}$ & $\mathrm{P}$ & $\mathrm{P}$ & $P$ & $\mathrm{P}$ & $\mathrm{P}$ & $\mathrm{P}$ & $\mathrm{P}$ & - & $P$ & - \\
\hline R.R.D. & $\mathrm{H}$ & 10,7 & $M$ & - & $\mathrm{P}$ & - & - & $\mathrm{P}$ & $\mathrm{P}$ & $\mathrm{P}$ & $\mathrm{P}$ & $\mathrm{P}$ & $\mathrm{P}$ & $\mathrm{P}$ & - & $\mathrm{P}$ & - \\
\hline J.A.R.C.M. & $\overline{\mathrm{H}}$ & 10,9 & $\bar{M}$ & - & $P$ & - & - & - & $\mathrm{P}$ & $P$ & $\mathrm{P}$ & $\mathrm{P}$ & - & - & - & $\mathrm{P}$ & - \\
\hline B.M.L. & $\mathrm{H}$ & 10,2 & $\mathrm{M}$ & - & $\mathrm{P}$ & - & $\mathrm{P}$ & - & $\mathrm{P}$ & $\mathrm{P}$ & $\mathrm{P}$ & $\mathrm{P}$ & - & $\mathrm{P}$ & - & $\mathrm{P}$ & - \\
\hline R.O.B.A. & $\mathrm{H}$ & 10,5 & $\mathrm{M}$ & - & $\mathrm{P}$ & $\mathrm{P}$ & $\mathrm{P}$ & $\mathrm{P}$ & $\mathrm{P}$ & $\mathrm{P}$ & $\mathrm{P}$ & $\mathrm{P}$ & $\mathrm{P}$ & $\mathrm{P}$ & $\mathrm{P}$ & $\mathrm{P}$ & - \\
\hline C.F.Z.S. & $\mathrm{H}$ & 10,0 & $\mathrm{~F}$ & - & $\mathrm{P}$ & - & $\mathrm{P}$ & - & $\mathrm{P}$ & $\mathrm{P}$ & $\mathrm{P}$ & $\mathrm{P}$ & - & $P$ & - & $\mathrm{P}$ & - \\
\hline M.P.P. & $\mathrm{H}$ & 10,5 & $\mathrm{~F}$ & - & $\mathrm{P}$ & - & - & $\mathrm{P}$ & $\mathrm{P}$ & $\mathrm{P}$ & $P$ & $\mathrm{P}$ & - & - & - & $\mathrm{P}$ & - \\
\hline T.F.D. & $\mathrm{H}$ & 10,0 & $\bar{M}$ & - & $\mathrm{P}$ & $\mathrm{P}$ & $\mathrm{P}$ & $\mathrm{P}$ & $\mathrm{P}$ & $\mathrm{P}$ & $\mathrm{P}$ & $\mathrm{P}$ & $\mathrm{P}$ & $\mathrm{P}$ & $\mathrm{P}$ & $\mathrm{P}$ & - \\
\hline C.L.C. & $\mathrm{H}$ & 10,2 & $\mathrm{~F}$ & - & $\mathrm{P}$ & $P$ & $\mathrm{P}$ & $\mathrm{P}$ & $\mathrm{P}$ & $\mathrm{P}$ & $\mathrm{P}$ & $\mathrm{P}$ & $\mathrm{P}$ & $\mathrm{P}$ & $P$ & $\mathrm{P}$ & - \\
\hline T.S.N.J. & $\mathrm{H}$ & 10,9 & $\mathrm{M}$ & - & $\mathrm{P}$ & - & $\mathrm{P}$ & $\mathrm{P}$ & $\mathrm{P}$ & $\mathrm{P}$ & $\mathrm{P}$ & $\mathrm{P}$ & $\mathrm{P}$ & $\mathrm{P}$ & - & $\mathrm{P}$ & - \\
\hline O.C.C. & $\mathrm{H}$ & 10,1 & $M$ & - & $\mathrm{P}$ & - & - & - & $\mathrm{P}$ & $\mathrm{P}$ & $\mathrm{P}$ & $\mathrm{P}$ & - & $\mathrm{P}$ & - & $\mathrm{P}$ & - \\
\hline J.A.A.C. & $\mathrm{H}$ & 10,7 & $\mathrm{M}$ & - & $P$ & - & $P$ & $\mathrm{P}$ & $\mathrm{P}$ & $P$ & $\mathrm{P}$ & $\mathrm{P}$ & - & - & - & $P$ & - \\
\hline P.B.B.M. & $\mathrm{H}$ & 10,8 & $\mathrm{~F}$ & $\mathrm{P}$ & $\mathrm{P}$ & $P$ & $\mathrm{P}$ & $\mathrm{P}$ & $\mathrm{P}$ & $\mathrm{P}$ & $\mathrm{P}$ & $\mathrm{P}$ & $\mathrm{P}$ & $\mathrm{P}$ & - & $\mathrm{P}$ & $\mathrm{P}$ \\
\hline M.H.T. & $\mathrm{H}$ & 10,0 & $\mathrm{~F}$ & - & $\mathrm{P}$ & - & - & - & $\mathrm{P}$ & $\mathrm{P}$ & $\mathrm{P}$ & $\mathrm{P}$ & - & - & - & $\mathrm{P}$ & - \\
\hline F.B. & $\mathrm{H}$ & 10,5 & $\mathrm{~F}$ & - & $\mathrm{P}$ & $P$ & $\mathrm{P}$ & $\mathrm{P}$ & $\mathrm{P}$ & $\mathrm{P}$ & $\mathrm{P}$ & $\mathrm{P}$ & $\mathrm{P}$ & $\mathrm{P}$ & - & $\mathrm{P}$ & - \\
\hline C.B.J. & $\mathrm{H}$ & 10,5 & $\mathrm{~F}$ & - & $\mathrm{P}$ & - & - & $\mathrm{P}$ & $\mathrm{P}$ & $\mathrm{P}$ & $\mathrm{P}$ & $\mathrm{P}$ & $\mathrm{P}$ & $\mathrm{P}$ & - & $\mathrm{P}$ & $\mathrm{P}$ \\
\hline D.E.H. & $\mathrm{H}$ & 10,6 & $\mathrm{~F}$ & - & $\mathrm{P}$ & $P$ & $\mathrm{P}$ & $\mathrm{P}$ & $\mathrm{P}$ & $\mathrm{P}$ & $\mathrm{P}$ & $\mathrm{P}$ & $\mathrm{P}$ & $\mathrm{P}$ & $P$ & $P$ & - \\
\hline M.L.P. & $\mathrm{H}$ & 10,0 & $\mathrm{~F}$ & $\mathrm{P}$ & $\mathrm{P}$ & - & $\mathrm{P}$ & $\mathrm{P}$ & $\mathrm{P}$ & $\mathrm{P}$ & $\mathrm{P}$ & $\mathrm{P}$ & $\mathrm{P}$ & $\mathrm{P}$ & $\mathrm{P}$ & $\mathrm{P}$ & $\mathrm{P}$ \\
\hline L.B. & $\mathrm{H}$ & 10,8 & $\mathrm{~F}$ & $\mathrm{P}$ & $\mathrm{P}$ & $P$ & $\mathrm{P}$ & $P$ & $P$ & $\mathrm{P}$ & $\mathrm{P}$ & $\mathrm{P}$ & $P$ & $\mathrm{P}$ & $P$ & $\mathrm{P}$ & $\mathrm{P}$ \\
\hline A.P.M.B. & $\mathrm{H}$ & 10,0 & $\mathrm{~F}$ & $P$ & $P$ & $P$ & $P$ & $\mathrm{P}$ & $\mathrm{P}$ & $P$ & $\mathrm{P}$ & $P$ & $\mathrm{P}$ & $P$ & $P$ & $P$ & $\mathrm{P}$ \\
\hline P.S.E. & $\mathrm{H}$ & 10,3 & $\mathrm{~F}$ & - & $P$ & - & $\mathrm{P}$ & - & $P$ & $P$ & $\mathrm{P}$ & $\mathrm{P}$ & - & $\mathrm{P}$ & - & $\mathrm{P}$ & - \\
\hline J.RN. & $\bar{H}$ & 10,9 & $M$ & - & $P$ & - & $P$ & $P$ & $P$ & $P$ & $P$ & $\mathrm{P}$ & - & - & $P$ & $P$ & - \\
\hline E.A. & $\mathrm{H}$ & 10,9 & $M$ & - & $P$ & $P$ & - & - & $P$ & $P$ & $P$ & $P$ & - & - & - & $P$ & - \\
\hline
\end{tabular}


Tabela A-16

\begin{tabular}{|c|c|c|c|c|c|c|c|c|c|c|c|c|c|c|c|c|c|}
\hline Nome & Grupo & Idade & Gênero & 17 & 16 & 15 & 14 & 13 & 12 & 11 & 21 & 22 & 23 & 24 & 25 & 26 & 27 \\
\hline T.V.S. & V & 11,0 & $M$ & - & $\mathrm{P}$ & - & $\mathrm{P}$ & - & $\mathrm{P}$ & $\mathrm{P}$ & $\mathrm{P}$ & $\mathrm{P}$ & $\mathrm{P}$ & $P$ & $\mathrm{P}$ & $\mathrm{P}$ & - \\
\hline R.A.A. & $\overline{\mathrm{V}}$ & 11,6 & $\bar{M}$ & - & $P$ & - & $P$ & - & $P$ & $P$ & $P$ & $\mathrm{P}$ & - & $P$ & - & $P$ & - \\
\hline D.F.D. & $\mathrm{V}$ & 11,0 & $M$ & - & $\mathrm{P}$ & $P$ & $\mathrm{P}$ & $\mathrm{P}$ & $P$ & $P$ & $P$ & $\mathrm{P}$ & $\mathrm{P}$ & $P$ & $\mathrm{P}$ & $P$ & - \\
\hline A.C.M. & $\mathrm{V}$ & 11,6 & $F$ & $P$ & $P$ & $\mathrm{P}$ & $P$ & $P$ & $P$ & $P$ & $P$ & $\mathrm{P}$ & $\mathrm{P}$ & $P$ & $P$ & $P$ & $P$ \\
\hline E.P.B. & $\mathrm{V}$ & 11,9 & $\mathrm{~F}$ & $\mathrm{P}$ & $\mathrm{P}$ & $\mathrm{P}$ & $\mathrm{P}$ & $\mathrm{P}$ & $\mathrm{P}$ & $\mathrm{P}$ & $\mathrm{P}$ & $\mathrm{P}$ & $\mathrm{P}$ & $P$ & $\mathrm{P}$ & $\mathrm{P}$ & $\mathrm{P}$ \\
\hline P.S.P.C. & $\mathrm{V}$ & 11,4 & $\mathrm{M}$ & - & $\mathrm{P}$ & $\mathrm{P}$ & $P$ & - & $\mathrm{P}$ & $P$ & $P$ & $\mathrm{P}$ & $P$ & $P$ & $P$ & $\mathrm{P}$ & - \\
\hline E.C.M. & V & 11,9 & $\mathrm{~F}$ & $P$ & $\mathrm{P}$ & $\mathrm{P}$ & $\mathrm{P}$ & $P$ & $\mathrm{P}$ & $\mathrm{P}$ & $\mathrm{P}$ & $P$ & $P$ & $P$ & $\mathrm{P}$ & $\mathrm{P}$ & $\mathrm{P}$ \\
\hline J.C.M.J. & $\mathrm{V}$ & 11,0 & $\mathrm{M}$ & - & $\mathrm{P}$ & $\mathrm{P}$ & $\mathrm{P}$ & - & $\mathrm{P}$ & $P$ & $\mathrm{P}$ & $\mathrm{P}$ & - & $P$ & $P$ & $\mathrm{P}$ & - \\
\hline M.A.P.T. & $\mathrm{V}$ & 11,0 & $\mathrm{M}$ & - & $\mathrm{P}$ & $\mathrm{P}$ & $P$ & - & $P$ & $\mathrm{P}$ & $\mathrm{P}$ & $P$ & - & $P$ & $\mathrm{P}$ & $P$ & - \\
\hline R.G.M. & $\mathrm{V}$ & 11,2 & $\mathrm{M}$ & - & $\mathrm{P}$ & - & $\mathrm{P}$ & $P$ & $\mathrm{P}$ & $\mathrm{P}$ & $\mathrm{P}$ & $\mathrm{P}$ & $\mathrm{P}$ & $P$ & $\mathrm{P}$ & $\mathrm{P}$ & - \\
\hline T.C.C.C. & V & 11,5 & $\mathrm{~F}$ & $\mathrm{P}$ & $P$ & $\mathrm{P}$ & $P$ & $\mathrm{P}$ & $\mathrm{P}$ & $P$ & $P$ & $P$ & $P$ & $P$ & $P$ & $\mathrm{P}$ & $\mathrm{P}$ \\
\hline M.Q.B. & $\mathrm{V}$ & 11,5 & $\mathrm{M}$ & $P$ & $\mathrm{P}$ & $\mathrm{P}$ & $P$ & $P$ & $\mathrm{P}$ & $P$ & $P$ & $P$ & $P$ & $P$ & $P$ & $P$ & $\mathrm{P}$ \\
\hline R.A.S.S. & $\mathrm{V}$ & 11,3 & $\mathrm{~F}$ & - & $P$ & - & - & - & $P$ & $P$ & $P$ & $P$ & - & - & - & $P$ & - \\
\hline R.B.R. & V & 11,1 & $\mathrm{~F}$ & - & $\mathrm{P}$ & $\mathrm{P}$ & $P$ & $\mathrm{P}$ & $P$ & $\mathrm{P}$ & $\mathrm{P}$ & $P$ & $P$ & $P$ & $P$ & $\mathrm{P}$ & - \\
\hline F.B.A. & $\mathrm{V}$ & 11,3 & $\mathrm{~F}$ & - & $P$ & $P$ & $P$ & $P$ & $\mathrm{P}$ & $P$ & $P$ & $P$ & $P$ & $P$ & $P$ & $P$ & - \\
\hline M.F.G. & $\mathrm{V}$ & 11,0 & $\mathrm{~F}$ & - & $P$ & - & $\mathrm{P}$ & $P$ & $\mathrm{P}$ & $P$ & $P$ & $P$ & - & $P$ & $P$ & $\mathrm{P}$ & - \\
\hline S.D. & $\mathrm{V}$ & 11.0 & $\mathrm{~F}$ & - & $P$ & $\mathrm{P}$ & $\mathrm{P}$ & $\mathrm{P}$ & $P$ & $P$ & $\mathrm{P}$ & $\mathrm{P}$ & $\mathrm{P}$ & $P$ & - & $\mathrm{P}$ & - \\
\hline E.F.Z. & $\mathrm{V}$ & 11,5 & $\mathrm{~F}$ & - & $P$ & $P$ & $P$ & $P$ & $P$ & $P$ & $P$ & $P$ & - & $P$ & - & $P$ & - \\
\hline M.G.T. & $\mathrm{V}$ & 11,6 & $\mathrm{M}$ & $P$ & $P$ & $\mathrm{P}$ & $\mathrm{P}$ & $P$ & $P$ & $P$ & $P$ & $P$ & $P$ & $P$ & $P$ & $P$ & $P$ \\
\hline R.T.D.G. & $\mathrm{V}$ & 11.9 & $M$ & $P$ & $P$ & $\mathrm{P}$ & $\mathrm{P}$ & $\mathrm{P}$ & $P$ & $P$ & $\mathrm{P}$ & $\mathrm{P}$ & $\mathrm{P}$ & $P$ & $P$ & $P$ & - \\
\hline G.C.T.N. & $\mathrm{V}$ & 11,0 & $\mathrm{M}$ & - & $P$ & - & $P$ & - & $P$ & $P$ & $P$ & $P$ & - & $P$ & - & $P$ & - \\
\hline R.Q. & $\mathrm{V}$ & 11,8 & $\mathrm{M}$ & - & $P$ & $P$ & $\mathrm{P}$ & - & $\mathrm{P}$ & $P$ & $P$ & $P$ & $P$ & $P$ & - & $P$ & - \\
\hline E.L.C.S. & $\mathrm{V}$ & 11,9 & $\mathrm{M}$ & $\mathrm{P}$ & $\mathrm{P}$ & $\mathrm{P}$ & $\mathrm{P}$ & $P$ & $\mathrm{P}$ & $\mathrm{P}$ & $\mathrm{P}$ & $\mathrm{P}$ & $\mathrm{P}$ & $P$ & $\mathrm{P}$ & $\mathrm{P}$ & $\mathrm{P}$ \\
\hline M.S. & $\mathrm{V}$ & 11,3 & $M$ & $P$ & $P$ & $\mathrm{P}$ & $P$ & $P$ & $P$ & $P$ & $P$ & $P$ & $\mathrm{P}$ & $P$ & $P$ & $P$ & $\mathrm{P}$ \\
\hline G.S.M. & $\mathrm{V}$ & 11,5 & $\bar{M}$ & $P$ & $\mathrm{P}$ & $P$ & $P$ & $P$ & $\mathrm{P}$ & $P$ & $P$ & $P$ & $P$ & $P$ & $P$ & $P$ & $P$ \\
\hline R.C.L.A. & $\mathrm{V}$ & 11,6 & $\mathrm{~F}$ & $\mathrm{P}$ & $\mathrm{P}$ & $\mathrm{P}$ & $\mathrm{P}$ & $\mathrm{P}$ & $\mathrm{P}$ & $\mathrm{P}$ & $\mathrm{P}$ & $\mathrm{P}$ & $\mathrm{P}$ & $P$ & $\mathrm{P}$ & $\mathrm{P}$ & $\mathrm{P}$ \\
\hline A.G.M. & $\mathrm{V}$ & 11,4 & $\bar{M}$ & - & $P$ & $P$ & $P$ & $\mathrm{P}$ & $\mathrm{P}$ & $\mathrm{P}$ & $P$ & $\mathrm{P}$ & - & $P$ & $\mathrm{P}$ & $P$ & - \\
\hline D.C.G.O. & $\mathrm{V}$ & 11,3 & $\mathrm{~F}$ & $P$ & $P$ & $P$ & $P$ & $P$ & $P$ & $P$ & $P$ & $P$ & $P$ & $P$ & $P$ & $P$ & $P$ \\
\hline C.Q. & $\mathrm{V}$ & 11,2 & $\mathrm{~F}$ & - & $\mathrm{P}$ & - & - & $\mathrm{P}$ & $\mathrm{P}$ & $\mathrm{P}$ & $\mathrm{P}$ & $\mathrm{P}$ & - & $P$ & - & $\mathrm{P}$ & - \\
\hline F.C.B. & $\mathrm{V}$ & 11,4 & $F$ & $\mathrm{P}$ & $\mathrm{P}$ & $\mathrm{P}$ & $P$ & $\mathrm{P}$ & $\mathrm{P}$ & $\mathrm{P}$ & $P$ & $\mathrm{P}$ & $P$ & $P$ & $\mathrm{P}$ & $P$ & $P$ \\
\hline R.P.F. & $\mathrm{H}$ & 11,7 & $\bar{M}$ & $P$ & $P$ & $P$ & $P$ & $P$ & $P$ & $P$ & $P$ & $\mathrm{P}$ & $P$ & $P$ & $P$ & $P$ & - \\
\hline A.C.D. & $\mathrm{H}$ & 11,5 & $\mathrm{~F}$ & $P$ & $P$ & $\mathrm{P}$ & $P$ & $\mathrm{P}$ & $\mathrm{P}$ & $P$ & $\mathrm{P}$ & $\mathrm{P}$ & $\mathrm{P}$ & $P$ & $P$ & $P$ & $\mathrm{P}$ \\
\hline F.S. & $\mathrm{H}$ & 11,5 & $\mathrm{M}$ & - & $\mathrm{P}$ & $\mathrm{P}$ & $\mathrm{P}$ & - & $P$ & $\mathrm{P}$ & $\mathrm{P}$ & $\mathrm{P}$ & - & $P$ & $\mathrm{P}$ & $\mathrm{P}$ & $\mathrm{P}$ \\
\hline E.C.L. & $\mathrm{H}$ & 11,8 & $\mathrm{~F}$ & $P$ & $P$ & $\mathrm{P}$ & $\mathrm{P}$ & $\mathrm{P}$ & $\mathrm{P}$ & $P$ & $\mathrm{P}$ & $\mathrm{P}$ & $\mathrm{P}$ & $P$ & $P$ & $P$ & $\mathrm{P}$ \\
\hline R.F.E. & $\mathrm{H}$ & 11,0 & $\mathrm{M}$ & $\mathrm{P}$ & $\mathrm{P}$ & $\mathrm{P}$ & $P$ & $P$ & $P$ & $\mathrm{P}$ & $\mathrm{P}$ & $\mathrm{P}$ & $\mathrm{P}$ & $P$ & $\mathrm{P}$ & $\mathrm{P}$ & $\mathrm{P}$ \\
\hline S.T.G. & $\mathrm{H}$ & 11,2 & $\mathrm{M}$ & - & $\mathrm{P}$ & $P$ & $P$ & - & $\mathrm{P}$ & $P$ & $P$ & $P$ & - & $P$ & $P$ & $P$ & - \\
\hline R.R.D. & $\mathrm{H}$ & 11,7 & $\bar{M}$ & - & $\mathrm{P}$ & $\mathrm{P}$ & $P$ & $\mathrm{P}$ & $\mathrm{P}$ & $P$ & $\mathrm{P}$ & $\mathrm{P}$ & $\mathrm{P}$ & $P$ & $\mathrm{P}$ & $\mathrm{P}$ & - \\
\hline J.A.R.C.M. & $\mathrm{H}$ & 11,9 & $\mathrm{M}$ & - & $P$ & - & $P$ & - & $P$ & $P$ & $P$ & $\mathrm{P}$ & - & - & - & $P$ & - \\
\hline B.M.L. & $\mathrm{H}$ & 11,0 & $\bar{M}$ & - & $P$ & $P$ & $P$ & $P$ & $P$ & $P$ & $P$ & $\mathrm{P}$ & $P$ & $P$ & $\mathrm{P}$ & $P$ & - \\
\hline C.F.Z.S. & $\mathrm{H}$ & 11,0 & $\mathrm{~F}$ & - & $P$ & - & $\mathrm{P}$ & - & $P$ & $P$ & $P$ & $\mathrm{P}$ & - & $P$ & $P$ & $P$ & - \\
\hline M.P.P. & $\mathrm{H}$ & 11,5 & $F$ & - & $\mathrm{P}$ & - & $\mathrm{P}$ & - & $\mathrm{P}$ & $\mathrm{P}$ & $\mathrm{P}$ & $\mathrm{P}$ & $\mathrm{P}$ & $P$ & - & $\mathrm{P}$ & - \\
\hline C.L.C. & $\mathrm{H}$ & 11,3 & $\mathrm{~F}$ & - & $\mathrm{P}$ & $\mathrm{P}$ & $\mathrm{P}$ & $\mathrm{P}$ & $\mathrm{P}$ & $\mathrm{P}$ & $\mathrm{P}$ & $\mathrm{P}$ & $\mathrm{P}$ & $P$ & $\mathrm{P}$ & $\mathrm{P}$ & $\mathrm{P}$ \\
\hline T.S.N.J. & $\mathrm{H}$ & 11,5 & $\mathrm{M}$ & - & $\mathrm{P}$ & $\mathrm{P}$ & $\mathrm{P}$ & $\mathrm{P}$ & $\mathrm{P}$ & $P$ & $P$ & $\mathrm{P}$ & $\mathrm{P}$ & $P$ & $P$ & $P$ & - \\
\hline J.A.A.C. & $\mathrm{H}$ & 11,9 & $M$ & - & $\mathrm{P}$ & $\mathrm{P}$ & $\mathrm{P}$ & $\mathrm{P}$ & $\mathrm{P}$ & $\mathrm{P}$ & $\mathrm{P}$ & $\mathrm{P}$ & $\mathrm{P}$ & $P$ & $\mathrm{P}$ & $\mathrm{P}$ & $\mathrm{P}$ \\
\hline P.B.B.M. & $\mathrm{H}$ & 11,8 & $\mathrm{~F}$ & $P$ & $\mathrm{P}$ & $\mathrm{P}$ & $\mathrm{P}$ & $\mathrm{P}$ & $P$ & $\mathrm{P}$ & $\mathrm{P}$ & $\mathrm{P}$ & $\mathrm{P}$ & $P$ & $\mathrm{P}$ & $\mathrm{P}$ & $\mathrm{P}$ \\
\hline M.H.T. & $\overline{\mathrm{H}}$ & 11,2 & $\mathrm{~F}$ & - & $\mathrm{P}$ & - & $P$ & $\mathrm{P}$ & $\mathrm{P}$ & $\mathrm{P}$ & $\mathrm{P}$ & $\mathrm{P}$ & - & $P$ & - & $\mathrm{P}$ & - \\
\hline F.B. & $\mathrm{H}$ & 11,5 & $F$ & $P$ & $\mathrm{P}$ & $\mathrm{P}$ & $\mathrm{P}$ & $P$ & $P$ & $\mathrm{P}$ & $\mathrm{P}$ & $\mathrm{P}$ & $P$ & $P$ & $\mathrm{P}$ & $\mathrm{P}$ & $P$ \\
\hline A.B.S.M. & $\mathrm{H}$ & 11,0 & $\mathrm{~F}$ & - & $\mathrm{P}$ & - & $P$ & - & $\mathrm{P}$ & $\mathrm{P}$ & $\mathrm{P}$ & $\mathrm{P}$ & - & - & - & $\mathrm{P}$ & - \\
\hline C.B.J. & $\mathrm{H}$ & 11,4 & $\mathrm{~F}$ & $P$ & $P$ & $P$ & $\mathrm{P}$ & $\mathrm{P}$ & $\mathrm{P}$ & $P$ & $P$ & $\mathrm{P}$ & $\mathrm{P}$ & $P$ & - & $P$ & $\mathrm{P}$ \\
\hline D.E.H. & $\mathrm{H}$ & 11,5 & $F$ & $P$ & $\mathrm{P}$ & $P$ & $P$ & $P$ & $P$ & $P$ & $P$ & $\mathrm{P}$ & $P$ & $P$ & $\mathrm{P}$ & $P$ & $\mathrm{P}$ \\
\hline D.A.M. & $\mathrm{H}$ & 11,7 & $M$ & - & $P$ & $\mathrm{P}$ & $\mathrm{P}$ & - & $\mathrm{P}$ & $\mathrm{P}$ & $\mathrm{P}$ & $\mathrm{P}$ & - & $P$ & - & $\mathrm{P}$ & - \\
\hline M.L.P. & $\mathrm{H}$ & 11,0 & $\mathrm{~F}$ & $\mathrm{P}$ & $\mathrm{P}$ & $\mathrm{P}$ & $\mathrm{P}$ & $\mathrm{P}$ & $\mathrm{P}$ & $\mathrm{P}$ & $\mathrm{P}$ & $\mathrm{P}$ & $\mathrm{P}$ & $P$ & $\mathrm{P}$ & $\mathrm{P}$ & $\mathrm{P}$ \\
\hline L.B. & $\mathrm{H}$ & 11,6 & $\mathrm{~F}$ & $\mathrm{P}$ & $\mathrm{P}$ & $\mathrm{P}$ & $\mathrm{P}$ & $\mathrm{P}$ & $\mathrm{P}$ & $\mathrm{P}$ & $\mathrm{P}$ & $\mathrm{P}$ & $\mathrm{P}$ & $P$ & $\mathrm{P}$ & $\mathrm{P}$ & $\mathrm{P}$ \\
\hline A.P.M.B. & $\mathrm{H}$ & 11,0 & $\mathrm{~F}$ & $\mathrm{P}$ & $\mathrm{P}$ & $\mathrm{P}$ & $\mathrm{P}$ & $\mathrm{P}$ & $\mathrm{P}$ & $\mathrm{P}$ & $P$ & $\mathrm{P}$ & $\mathrm{P}$ & $\mathrm{P}$ & $P$ & $P$ & $\mathrm{P}$ \\
\hline P.S.E. & $\mathrm{H}$ & 11,4 & $\mathrm{~F}$ & $\mathrm{P}$ & $\mathrm{P}$ & - & - & - & $\mathrm{P}$ & $\mathrm{P}$ & $\mathrm{P}$ & $\mathrm{P}$ & - & - & - & $\mathrm{P}$ & $\mathrm{P}$ \\
\hline J.R.N. & $\mathrm{H}$ & 11,9 & $\mathrm{M}$ & - & $P$ & - & $P$ & - & $P$ & $P$ & $P$ & $P$ & $P$ & $P$ & - & $P$ & - \\
\hline E.A. & $\mathrm{H}$ & 11,8 & $M$ & $P$ & $P$ & $P$ & $P$ & $P$ & $\mathrm{P}$ & $P$ & $P$ & $P$ & - & $P$ & $P$ & $P$ & $\mathrm{P}$ \\
\hline C.S.D. & $\mathrm{H}$ & 11,0 & $\mathrm{~F}$ & - & $\mathrm{P}$ & $\mathrm{P}$ & $\mathrm{P}$ & - & $\mathrm{P}$ & $P$ & $P$ & $\mathrm{P}$ & - & $P$ & $P$ & $P$ & - \\
\hline V.C.P. & $\mathrm{H}$ & 11,1 & $\mathrm{~F}$ & - & $\mathrm{P}$ & - & $P$ & - & $P$ & $P$ & $P$ & $P$ & $P$ & $P$ & - & $P$ & - \\
\hline R.V.D. & $\mathrm{H}$ & 11,2 & $\mathrm{M}$ & - & $\mathrm{P}$ & $\mathrm{P}$ & $\mathrm{P}$ & - & $\mathrm{P}$ & $\mathrm{P}$ & $\mathrm{P}$ & $\mathrm{P}$ & - & $P$ & $\mathrm{P}$ & $\mathrm{P}$ & $\mathrm{P}$ \\
\hline
\end{tabular}


Tabela A-17

\begin{tabular}{|c|c|c|c|c|c|c|c|c|c|c|c|c|c|c|c|c|c|}
\hline Nome & Grupo & Idade & Gênero & 37 & 36 & 35 & 34 & 33 & 32 & 31 & 41 & 42 & 43 & 44 & 45 & 46 & 47 \\
\hline T.V.S. & V & 11,0 & $\mathrm{M}$ & - & $P$ & - & $P$ & $P$ & $P$ & $P$ & $P$ & $P$ & $P$ & $P$ & - & $P$ & - \\
\hline R.A.A. & $\mathrm{V}$ & 11,6 & $M$ & - & $P$ & - & - & - & $P$ & $P$ & $P$ & $P$ & $P$ & - & - & $P$ & - \\
\hline D.F.D. & V & 11,0 & $M$ & - & $\mathrm{P}$ & $\mathrm{P}$ & $\mathrm{P}$ & $\mathrm{P}$ & $\mathrm{P}$ & $\mathrm{P}$ & $\mathrm{P}$ & $\mathrm{P}$ & $\mathrm{P}$ & $\mathrm{P}$ & $\mathrm{P}$ & $\mathrm{P}$ & $P$ \\
\hline A.C.M. & V & 11,6 & $\mathrm{~F}$ & $\mathrm{P}$ & $\mathrm{P}$ & $\mathrm{P}$ & $P$ & $P$ & $\mathrm{P}$ & $P$ & $P$ & $P$ & $\mathrm{P}$ & $\mathrm{P}$ & $P$ & $P$ & $P$ \\
\hline E.P.B. & V & 11,9 & $\mathrm{~F}$ & $\mathrm{P}$ & $\mathrm{P}$ & $\mathrm{P}$ & $P$ & $P$ & $P$ & $P$ & $P$ & $\mathrm{P}$ & $\mathrm{P}$ & $\mathrm{P}$ & $\mathrm{P}$ & $P$ & $P$ \\
\hline P.S.P.C. & $\mathrm{V}$ & 11,4 & $\mathrm{M}$ & - & $\mathrm{P}$ & - & $P$ & $\mathrm{P}$ & $P$ & $P$ & $\mathrm{P}$ & $\mathrm{P}$ & $\mathrm{P}$ & $\mathrm{P}$ & - & $\mathrm{P}$ & - \\
\hline E.C.M. & V & 11,9 & $\mathrm{~F}$ & $\mathrm{P}$ & $\mathrm{P}$ & $\mathrm{P}$ & $P$ & $\mathrm{P}$ & $\mathrm{P}$ & $P$ & $P$ & $\mathrm{P}$ & $\mathrm{P}$ & $\mathrm{P}$ & $\mathrm{P}$ & $P$ & $P$ \\
\hline J.C.M.J. & V & 11,0 & $M$ & - & $\mathrm{P}$ & - & - & - & $\mathrm{P}$ & $\mathrm{P}$ & $\mathrm{P}$ & $\mathrm{P}$ & - & - & - & $\mathrm{P}$ & - \\
\hline M.A.P.T. & $\mathrm{V}$ & 11,0 & $\bar{M}$ & $\mathrm{P}$ & $P$ & - & - & - & $P$ & $\mathrm{P}$ & $\mathrm{P}$ & $\mathrm{P}$ & $\mathrm{P}$ & - & $\mathrm{P}$ & $\mathrm{P}$ & - \\
\hline R.G.M. & $\mathrm{V}$ & 11,2 & $M$ & - & $\mathrm{P}$ & $\mathrm{P}$ & $\mathrm{P}$ & $\mathrm{P}$ & $\mathrm{P}$ & $P$ & $\mathrm{P}$ & $\mathrm{P}$ & $\mathrm{P}$ & $\mathrm{P}$ & $\mathrm{P}$ & $P$ & - \\
\hline T.C.C.C. & V & 11,5 & $\mathrm{~F}$ & $\mathrm{P}$ & $\mathrm{P}$ & $\mathrm{P}$ & $\mathrm{P}$ & $\mathrm{P}$ & $\mathrm{P}$ & $\mathrm{P}$ & $\mathrm{P}$ & $\mathrm{P}$ & $\mathrm{P}$ & $\mathrm{P}$ & $\mathrm{P}$ & $\mathrm{P}$ & $P$ \\
\hline M.Q.B. & $\mathrm{V}$ & 11,5 & $\bar{M}$ & $\mathrm{P}$ & $\mathrm{P}$ & $\mathrm{P}$ & $\mathrm{P}$ & $\mathrm{P}$ & $\mathrm{P}$ & $\mathrm{P}$ & $\mathrm{P}$ & $\mathrm{P}$ & $\mathrm{P}$ & $\mathrm{P}$ & $\mathrm{P}$ & $\mathrm{P}$ & $\mathrm{P}$ \\
\hline R.A.S.S. & $\mathrm{V}$ & 11,3 & $\mathrm{~F}$ & - & $\mathrm{P}$ & $\mathrm{P}$ & $\mathrm{P}$ & $\mathrm{P}$ & $\mathrm{P}$ & $\mathrm{P}$ & $\mathrm{P}$ & $\mathrm{P}$ & $\mathrm{P}$ & - & - & $\mathrm{P}$ & - \\
\hline R.B.R. & V & 11,1 & $\mathrm{~F}$ & - & $\mathrm{P}$ & $\mathrm{P}$ & $P$ & $\mathrm{P}$ & $\mathrm{P}$ & $P$ & $P$ & $P$ & $\mathrm{P}$ & $\mathrm{P}$ & $\mathrm{P}$ & $P$ & - \\
\hline F.B.A. & $\mathrm{V}$ & 11,3 & $\mathrm{~F}$ & - & $\mathrm{P}$ & $\mathrm{P}$ & $P$ & $\mathrm{P}$ & $\mathrm{P}$ & $P$ & $P$ & $\mathrm{P}$ & $\mathrm{P}$ & $P$ & $\mathrm{P}$ & $P$ & - \\
\hline M.F.G. & $\mathrm{V}$ & 11,0 & $\mathrm{~F}$ & - & $\mathrm{P}$ & - & $\mathrm{P}$ & - & $\mathrm{P}$ & $\mathrm{P}$ & $\mathrm{P}$ & $\mathrm{P}$ & $\mathrm{P}$ & $\mathrm{P}$ & - & $\mathrm{P}$ & - \\
\hline S.D. & $\mathrm{V}$ & 11,0 & $\mathrm{~F}$ & - & $P$ & - & $\mathrm{P}$ & $\mathrm{P}$ & $P$ & $\mathrm{P}$ & $\mathrm{P}$ & $\mathrm{P}$ & $\mathrm{P}$ & $\mathrm{P}$ & - & $\mathrm{P}$ & - \\
\hline E.F.Z. & $\mathrm{V}$ & 11,5 & $\mathrm{~F}$ & - & $\mathrm{P}$ & $\mathrm{P}$ & $\mathrm{P}$ & $\mathrm{P}$ & $\mathrm{P}$ & $\mathrm{P}$ & $\mathrm{P}$ & $\mathrm{P}$ & $\mathrm{P}$ & $\mathrm{P}$ & - & $\mathrm{P}$ & - \\
\hline M.G.T. & $\mathrm{V}$ & 11,6 & $\bar{M}$ & $\mathrm{P}$ & $\mathrm{P}$ & $\mathrm{P}$ & $\mathrm{P}$ & $\mathrm{P}$ & $\mathrm{P}$ & $\mathrm{P}$ & $\mathrm{P}$ & $\mathrm{P}$ & $\mathrm{P}$ & $\mathrm{P}$ & $\mathrm{P}$ & $\mathrm{P}$ & $\mathrm{P}$ \\
\hline R.T.D.G. & $\mathrm{V}$ & 11,9 & $\bar{M}$ & $\mathrm{P}$ & $P$ & - & $\mathrm{P}$ & $\mathrm{P}$ & $P$ & $\mathrm{P}$ & $\mathrm{P}$ & $\mathrm{P}$ & $\mathrm{P}$ & $\mathrm{P}$ & - & $\mathrm{P}$ & - \\
\hline G.C.T.N. & V & 11,0 & $M$ & - & $\mathrm{P}$ & - & $\mathrm{P}$ & - & $\mathrm{P}$ & $\mathrm{P}$ & $\mathrm{P}$ & $\mathrm{P}$ & $\mathrm{P}$ & $\mathrm{P}$ & - & $\mathrm{P}$ & - \\
\hline R.Q. & V & 11,8 & $\mathrm{M}$ & $\mathrm{P}$ & $P$ & - & $\mathrm{P}$ & $\mathrm{P}$ & $\mathrm{P}$ & $\mathrm{P}$ & $\mathrm{P}$ & $\mathrm{P}$ & $\mathrm{P}$ & $\mathrm{P}$ & - & $\mathrm{P}$ & $P$ \\
\hline E.L.C.S. & $\mathrm{V}$ & 11,9 & $M$ & $\mathrm{P}$ & $\mathrm{P}$ & $\mathrm{P}$ & $\mathrm{P}$ & $\mathrm{P}$ & $\mathrm{P}$ & $\mathrm{P}$ & $\mathrm{P}$ & $\mathrm{P}$ & $\mathrm{P}$ & $\mathrm{P}$ & $\mathrm{P}$ & $\mathrm{P}$ & $\mathrm{P}$ \\
\hline M.S. & $\mathrm{V}$ & 11,3 & $\mathrm{M}$ & $\mathrm{P}$ & $\mathrm{P}$ & $\mathrm{P}$ & $\mathrm{P}$ & $\mathrm{P}$ & $\mathrm{P}$ & $\mathrm{P}$ & $\mathrm{P}$ & $\mathrm{P}$ & $\mathrm{P}$ & $\mathrm{P}$ & $\mathrm{P}$ & $\mathrm{P}$ & $\mathrm{P}$ \\
\hline G.S.M. & $\mathrm{V}$ & 11,5 & $M$ & $\mathrm{P}$ & $P$ & $\mathrm{P}$ & $\mathrm{P}$ & $\mathrm{P}$ & $\mathrm{P}$ & $\mathrm{P}$ & $\mathrm{P}$ & $\mathrm{P}$ & $\mathrm{P}$ & $\mathrm{P}$ & $\mathrm{P}$ & $\mathrm{P}$ & $\mathrm{P}$ \\
\hline R.C.L.A. & $\bar{V}$ & 11,6 & $\mathrm{~F}$ & $\mathrm{P}$ & $\mathrm{P}$ & $P$ & $\mathrm{P}$ & $\mathrm{P}$ & $\mathrm{P}$ & $\mathrm{P}$ & $\mathrm{P}$ & $\mathrm{P}$ & $\mathrm{P}$ & $\mathrm{P}$ & $\mathrm{P}$ & $\mathrm{P}$ & $P$ \\
\hline A.G.M. & $\mathrm{V}$ & 11,4 & $\bar{M}$ & - & $P$ & - & $P$ & $P$ & $\mathrm{P}$ & $P$ & $P$ & $P$ & $\mathrm{P}$ & $P$ & $P$ & $P$ & - \\
\hline D.C.G.O. & $\mathrm{V}$ & 11,3 & $\mathrm{~F}$ & $\mathrm{P}$ & $\mathrm{P}$ & - & $\mathrm{P}$ & $\mathrm{P}$ & $\mathrm{P}$ & $\mathrm{P}$ & $\mathrm{P}$ & $\mathrm{P}$ & $\mathrm{P}$ & $\mathrm{P}$ & $\mathrm{P}$ & $\mathrm{P}$ & $\mathrm{P}$ \\
\hline C.Q. & $\mathrm{V}$ & 11,2 & $\mathrm{~F}$ & - & $\mathrm{P}$ & $\mathrm{P}$ & $\mathrm{P}$ & $\mathrm{P}$ & $\mathrm{P}$ & $\mathrm{P}$ & $\mathrm{P}$ & $\mathrm{P}$ & $\mathrm{P}$ & $\mathrm{P}$ & $\mathrm{P}$ & $\mathrm{P}$ & - \\
\hline F.C.B. & $\mathrm{V}$ & 11,4 & $\mathrm{~F}$ & $\mathrm{P}$ & $P$ & $\mathrm{P}$ & $\mathrm{P}$ & $\mathrm{P}$ & $\mathrm{P}$ & $\mathrm{P}$ & $\mathrm{P}$ & $\mathrm{P}$ & $\mathrm{P}$ & $\mathrm{P}$ & $\mathrm{P}$ & $\mathrm{P}$ & $\mathrm{P}$ \\
\hline R.P.F. & $\overline{\mathrm{H}}$ & 11,7 & $\bar{M}$ & - & $P$ & - & $\mathrm{P}$ & $\mathrm{P}$ & $\mathrm{P}$ & $\mathrm{P}$ & $\mathrm{P}$ & $\mathrm{P}$ & $\mathrm{P}$ & $\mathrm{P}$ & $\mathrm{P}$ & $\mathrm{P}$ & $\mathrm{P}$ \\
\hline A.C.D. & $\overline{\mathrm{H}}$ & 11,5 & $\mathrm{~F}$ & $\mathrm{P}$ & $P$ & $\mathrm{P}$ & $\mathrm{P}$ & $\mathrm{P}$ & $\mathrm{P}$ & $\mathrm{P}$ & $\mathrm{P}$ & $\mathrm{P}$ & $\mathrm{P}$ & $\mathrm{P}$ & $\mathrm{P}$ & $\mathrm{P}$ & $P$ \\
\hline F.S. & $\mathrm{H}$ & 11,5 & $\bar{M}$ & $\mathrm{P}$ & $P$ & $\mathrm{P}$ & $\mathrm{P}$ & $\mathrm{P}$ & $\mathrm{P}$ & $\mathrm{P}$ & $\mathrm{P}$ & $\mathrm{P}$ & $\mathrm{P}$ & $\mathrm{P}$ & $\mathrm{P}$ & $\mathrm{P}$ & $P$ \\
\hline E.C.L. & $\mathrm{H}$ & 11,8 & $\mathrm{~F}$ & $\mathrm{P}$ & $\mathrm{P}$ & $\mathrm{P}$ & $\mathrm{P}$ & $\mathrm{P}$ & $\mathrm{P}$ & $\mathrm{P}$ & $\mathrm{P}$ & $\mathrm{P}$ & $\mathrm{P}$ & $\mathrm{P}$ & $\mathrm{P}$ & $\mathrm{P}$ & $P$ \\
\hline R.F.E. & $\mathrm{H}$ & 11,0 & $\bar{M}$ & $\mathrm{P}$ & $P$ & $\mathrm{P}$ & $\mathrm{P}$ & $\mathrm{P}$ & $P$ & $\mathrm{P}$ & $\mathrm{P}$ & $\mathrm{P}$ & $P$ & $\mathrm{P}$ & $P$ & $\mathrm{P}$ & $P$ \\
\hline S.T.G. & $\mathrm{H}$ & 11,2 & $M$ & - & $\mathrm{P}$ & $\mathrm{P}$ & $\mathrm{P}$ & $\mathrm{P}$ & $\mathrm{P}$ & $\mathrm{P}$ & $\mathrm{P}$ & $\mathrm{P}$ & $\mathrm{P}$ & $\mathrm{P}$ & - & $\mathrm{P}$ & - \\
\hline R.R.D. & $\mathrm{H}$ & 11,7 & $M$ & - & $\mathrm{P}$ & $\mathrm{P}$ & $\mathrm{P}$ & $\mathrm{P}$ & $\mathrm{P}$ & $\mathrm{P}$ & $\mathrm{P}$ & $\mathrm{P}$ & $\mathrm{P}$ & $\mathrm{P}$ & $\mathrm{P}$ & $\mathrm{P}$ & - \\
\hline J.A.R.C.M. & $\mathrm{H}$ & 11,9 & $\mathrm{M}$ & - & $\mathrm{P}$ & $\mathrm{P}$ & - & $\mathrm{P}$ & $\mathrm{P}$ & $\mathrm{P}$ & $\mathrm{P}$ & $\mathrm{P}$ & $\mathrm{P}$ & - & $\mathrm{P}$ & $\mathrm{P}$ & - \\
\hline B.M.L. & $\mathrm{H}$ & 11,0 & $M$ & - & $\mathrm{P}$ & $\mathrm{P}$ & $\mathrm{P}$ & $\mathrm{P}$ & $\mathrm{P}$ & $\mathrm{P}$ & $\mathrm{P}$ & $\mathrm{P}$ & $\mathrm{P}$ & $\mathrm{P}$ & - & $\mathrm{P}$ & $P$ \\
\hline C.F.Z.S. & $\mathrm{H}$ & 11,0 & $\mathrm{~F}$ & - & $\mathrm{P}$ & $\mathrm{P}$ & $\mathrm{P}$ & $\mathrm{P}$ & $\mathrm{P}$ & $\mathrm{P}$ & $\mathrm{P}$ & $\mathrm{P}$ & $\mathrm{P}$ & $\mathrm{P}$ & $\mathrm{P}$ & $\mathrm{P}$ & - \\
\hline M.P.P. & $\mathrm{H}$ & 11,5 & $\mathrm{~F}$ & $\mathrm{P}$ & $\mathrm{P}$ & - & $\mathrm{P}$ & $\mathrm{P}$ & $\mathrm{P}$ & $\mathrm{P}$ & $\mathrm{P}$ & $\mathrm{P}$ & $\mathrm{P}$ & $\mathrm{P}$ & - & $\mathrm{P}$ & - \\
\hline C.L.C. & $\mathrm{H}$ & 11,3 & $\mathrm{~F}$ & $\mathrm{P}$ & $\mathrm{P}$ & $\mathrm{P}$ & $\mathrm{P}$ & $\mathrm{P}$ & $P$ & $\mathrm{P}$ & $P$ & $\mathrm{P}$ & $\mathrm{P}$ & $P$ & $\mathrm{P}$ & $\mathrm{P}$ & $P$ \\
\hline T.S.N.J. & $\mathrm{H}$ & 11,5 & $M$ & - & $P$ & $\mathrm{P}$ & $\mathrm{P}$ & $\mathrm{P}$ & $\mathrm{P}$ & $\mathrm{P}$ & $\mathrm{P}$ & $\mathrm{P}$ & $\mathrm{P}$ & $\mathrm{P}$ & - & $\mathrm{P}$ & - \\
\hline J.A.A.C. & $\mathrm{H}$ & 11,9 & $M$ & - & $\mathrm{P}$ & $\mathrm{P}$ & $\mathrm{P}$ & $\mathrm{P}$ & $\mathrm{P}$ & $\mathrm{P}$ & $\mathrm{P}$ & $\mathrm{P}$ & $\mathrm{P}$ & $\mathrm{P}$ & $\mathrm{P}$ & $\mathrm{P}$ & - \\
\hline P.B.B.M. & $\mathrm{H}$ & 11,8 & $\bar{F}$ & $\mathrm{P}$ & $\mathrm{P}$ & $\mathrm{P}$ & $\mathrm{P}$ & $\mathrm{P}$ & $\mathrm{P}$ & $\mathrm{P}$ & $\mathrm{P}$ & $\mathrm{P}$ & $\mathrm{P}$ & $\mathrm{P}$ & $\mathrm{P}$ & $\mathrm{P}$ & $P$ \\
\hline M.H.T. & $\overline{\mathrm{H}}$ & 11,2 & $\mathrm{~F}$ & - & $P$ & - & - & $\mathrm{P}$ & $\mathrm{P}$ & $\mathrm{P}$ & $\mathrm{P}$ & $\mathrm{P}$ & $\mathrm{P}$ & - & - & $\mathrm{P}$ & - \\
\hline F.B. & $\mathrm{H}$ & 11,5 & $F$ & $\mathrm{P}$ & $\mathrm{P}$ & $\mathrm{P}$ & $\mathrm{P}$ & $\mathrm{P}$ & $\mathrm{P}$ & $P$ & $P$ & $P$ & $\mathrm{P}$ & $P$ & $\mathrm{P}$ & $P$ & $P$ \\
\hline A.B.S.M. & $\mathrm{H}$ & 11,0 & $\mathrm{~F}$ & - & $\mathrm{P}$ & - & - & $\mathrm{P}$ & $\mathrm{P}$ & $\mathrm{P}$ & $\mathrm{P}$ & $\mathrm{P}$ & $P$ & - & - & $\mathrm{P}$ & - \\
\hline C.B.J. & $\mathrm{H}$ & 11,4 & $\mathrm{~F}$ & $\mathrm{P}$ & $\mathrm{P}$ & - & $\mathrm{P}$ & $\mathrm{P}$ & $P$ & $\mathrm{P}$ & $P$ & $P$ & $\mathrm{P}$ & $\mathrm{P}$ & $\mathrm{P}$ & $\mathrm{P}$ & $P$ \\
\hline D.E.H. & $\mathrm{H}$ & 11,5 & $\mathrm{~F}$ & $P$ & $\mathrm{P}$ & $\mathrm{P}$ & $\mathrm{P}$ & $P$ & $\mathrm{P}$ & $P$ & $P$ & $\mathrm{P}$ & $\mathrm{P}$ & $\mathrm{P}$ & $P$ & $\mathrm{P}$ & $P$ \\
\hline D.A.M. & $\mathrm{H}$ & 11,7 & $\mathrm{M}$ & $\mathrm{P}$ & $\mathrm{P}$ & $\mathrm{P}$ & $\mathrm{P}$ & $\mathrm{P}$ & $\mathrm{P}$ & $\mathrm{P}$ & $\mathrm{P}$ & $\mathrm{P}$ & $\mathrm{P}$ & $\mathrm{P}$ & - & $\mathrm{P}$ & $P$ \\
\hline M.L.P. & $\mathrm{H}$ & 11,0 & $\mathrm{~F}$ & $\mathrm{P}$ & $\mathrm{P}$ & $\mathrm{P}$ & $P$ & $\mathrm{P}$ & $\mathrm{P}$ & $P$ & $P$ & $P$ & $\mathrm{P}$ & $\mathrm{P}$ & $\mathrm{P}$ & $P$ & $\mathrm{P}$ \\
\hline L.B. & $\mathrm{H}$ & 11,6 & $\mathrm{~F}$ & $\mathrm{P}$ & $\mathrm{P}$ & $\mathrm{P}$ & $\mathrm{P}$ & $\mathrm{P}$ & $\mathrm{P}$ & $\mathrm{P}$ & $\mathrm{P}$ & $\mathrm{P}$ & $\mathrm{P}$ & $\mathrm{P}$ & $\mathrm{P}$ & $\mathrm{P}$ & $\mathrm{P}$ \\
\hline A.P. M.B. & $\mathrm{H}$ & 11,0 & $\mathrm{~F}$ & $P$ & $P$ & $\mathrm{P}$ & $P$ & $\mathrm{P}$ & $P$ & $P$ & $P$ & $P$ & $\mathrm{P}$ & $\mathrm{P}$ & $\mathrm{P}$ & $P$ & $\mathrm{P}$ \\
\hline P.S.E. & $\mathrm{H}$ & 11,4 & $\mathrm{~F}$ & - & $\mathrm{P}$ & - & $\mathrm{P}$ & $\mathrm{P}$ & $\mathrm{P}$ & $\mathrm{P}$ & $\mathrm{P}$ & $\mathrm{P}$ & $\mathrm{P}$ & $\mathrm{P}$ & - & $\mathrm{P}$ & - \\
\hline J.R.N. & $\overline{\mathrm{H}}$ & 11,9 & $\mathrm{M}$ & - & $\mathrm{P}$ & $\mathrm{P}$ & $\mathrm{P}$ & $\mathrm{P}$ & $P$ & $\mathrm{P}$ & $\mathrm{P}$ & $\mathrm{P}$ & $\mathrm{P}$ & $\mathrm{P}$ & $\mathrm{P}$ & $\mathrm{P}$ & - \\
\hline E.A. & $\mathrm{H}$ & 11,8 & $M$ & $\mathrm{P}$ & $\mathrm{P}$ & $P$ & $P$ & - & $\mathrm{P}$ & $P$ & $P$ & $\mathrm{P}$ & - & $P$ & $\mathrm{P}$ & $P$ & $P$ \\
\hline C.S.D. & $\mathrm{H}$ & 11,0 & $\mathrm{~F}$ & - & $\mathrm{P}$ & $\mathrm{P}$ & $\mathrm{P}$ & $\mathrm{P}$ & $\mathrm{P}$ & $\mathrm{P}$ & $\mathrm{P}$ & $\mathrm{P}$ & $\mathrm{P}$ & $\mathrm{P}$ & $\mathrm{P}$ & $\mathrm{P}$ & - \\
\hline V.C.P. & $\overline{\mathrm{H}}$ & 11,1 & $\mathrm{~F}$ & $\mathrm{P}$ & $P$ & $P$ & $P$ & $\mathrm{P}$ & $P$ & $\mathrm{P}$ & $\mathrm{P}$ & $\mathrm{P}$ & $\mathrm{P}$ & $P$ & $\mathrm{P}$ & $\mathrm{P}$ & $P$ \\
\hline R.V.D. & $\overline{\mathrm{H}}$ & 11,2 & $\bar{M}$ & $\mathrm{P}$ & $P$ & $\mathrm{P}$ & - & - & $P$ & $\mathrm{P}$ & $\mathrm{P}$ & $\mathrm{P}$ & - & - & - & $\mathrm{P}$ & $\mathrm{P}$ \\
\hline
\end{tabular}


Tabela A-18

\begin{tabular}{|c|c|c|c|c|c|c|c|c|c|c|c|c|c|c|c|c|c|}
\hline Nome & Grupo & Idade & Gênero & 17 & 16 & 15 & 14 & 13 & 12 & 11 & 21 & 22 & 23 & 24 & 25 & 26 & 27 \\
\hline A.C.M. & V & 12,5 & $\mathrm{~F}$ & $\mathrm{P}$ & $\mathrm{P}$ & $\mathrm{P}$ & $\mathrm{P}$ & $\mathrm{P}$ & $\mathrm{P}$ & $\mathrm{P}$ & $\mathrm{P}$ & $\mathrm{P}$ & $\mathrm{P}$ & $\mathrm{P}$ & $P$ & $\mathrm{P}$ & $\mathrm{P}$ \\
\hline P.S.P.C. & $\mathrm{V}$ & 12,4 & $\mathrm{M}$ & - & $\mathrm{P}$ & $\mathrm{P}$ & $\mathrm{P}$ & $\mathrm{P}$ & $\mathrm{P}$ & $\mathrm{P}$ & $\mathrm{P}$ & $\mathrm{P}$ & $\mathrm{P}$ & $\mathrm{P}$ & $\mathrm{P}$ & $\mathrm{P}$ & - \\
\hline E.C.M. & $\mathrm{V}$ & 12,0 & $\mathrm{~F}$ & $P$ & $\mathrm{P}$ & $\mathrm{P}$ & $\mathrm{P}$ & $\mathrm{P}$ & $\mathrm{P}$ & $\mathrm{P}$ & $\mathrm{P}$ & $\mathrm{P}$ & $\mathrm{P}$ & $\mathrm{P}$ & $\mathrm{P}$ & $\mathrm{P}$ & $\mathrm{P}$ \\
\hline J.C.M.J. & $\mathrm{V}$ & 12,0 & $\mathrm{M}$ & - & $\mathrm{P}$ & $\mathrm{P}$ & $\mathrm{P}$ & - & $\mathrm{P}$ & $\mathrm{P}$ & $\mathrm{P}$ & $\mathrm{P}$ & $\mathrm{P}$ & $\mathrm{P}$ & $\mathrm{P}$ & $\mathrm{P}$ & - \\
\hline M.A.P.T. & $\mathrm{V}$ & 12,0 & $\mathrm{M}$ & $\mathrm{P}$ & $\mathrm{P}$ & $\mathrm{P}$ & $\mathrm{P}$ & $\mathrm{P}$ & $\mathrm{P}$ & $\mathrm{P}$ & $\mathrm{P}$ & $\mathrm{P}$ & $\mathrm{P}$ & $\mathrm{P}$ & $\mathrm{P}$ & $\mathrm{P}$ & $\mathrm{P}$ \\
\hline P.B.J. & $\mathrm{V}$ & 12,8 & $M$ & $\mathrm{P}$ & $\mathrm{P}$ & $\mathrm{P}$ & $\mathrm{P}$ & - & $\mathrm{P}$ & $\mathrm{P}$ & $\mathrm{P}$ & $P$ & - & $P$ & $P$ & $\mathrm{P}$ & $\mathrm{P}$ \\
\hline R.G.M. & $\mathrm{V}$ & 12,2 & $\mathrm{M}$ & $P$ & $\mathrm{P}$ & $\mathrm{P}$ & $P$ & $P$ & $\mathrm{P}$ & $\mathrm{P}$ & $P$ & $P$ & $P$ & $P$ & $P$ & $P$ & $\mathrm{P}$ \\
\hline T.C.C.C. & V & 12,0 & $\mathrm{~F}$ & $P$ & $\mathrm{P}$ & $\mathrm{P}$ & $\mathrm{P}$ & $\mathrm{P}$ & $\mathrm{P}$ & $\mathrm{P}$ & $\mathrm{P}$ & $\mathrm{P}$ & $\mathrm{P}$ & $P$ & $P$ & $\mathrm{P}$ & $\mathrm{P}$ \\
\hline M.Q.B. & $\mathrm{V}$ & 12,0 & $\mathrm{M}$ & $P$ & $P$ & $P$ & $P$ & $P$ & $P$ & $P$ & $\mathrm{P}$ & $P$ & $\mathrm{P}$ & $P$ & $\mathrm{P}$ & $P$ & $\mathrm{P}$ \\
\hline R.A.S.S. & $\mathrm{V}$ & 12,4 & $\mathrm{~F}$ & - & $\mathrm{P}$ & - & - & - & $\mathrm{P}$ & $P$ & $\mathrm{P}$ & $P$ & - & - & - & $\mathrm{P}$ & - \\
\hline R.B.R. & V & 12,2 & $\mathrm{~F}$ & - & $\mathrm{P}$ & $\mathrm{P}$ & $\mathrm{P}$ & $\mathrm{P}$ & $\mathrm{P}$ & $P$ & $P$ & $P$ & $P$ & $P$ & $P$ & $\mathrm{P}$ & $\mathrm{P}$ \\
\hline F.B.A. & $\mathrm{V}$ & 12,4 & $\mathrm{~F}$ & - & $\mathrm{P}$ & $P$ & $P$ & $P$ & $\mathrm{P}$ & $\mathrm{P}$ & $\mathrm{P}$ & $\mathrm{P}$ & $\mathrm{P}$ & $\mathrm{P}$ & $P$ & $\mathrm{P}$ & - \\
\hline M.F.G. & $\mathrm{V}$ & 12,0 & $\mathrm{~F}$ & $P$ & $\mathrm{P}$ & $\mathrm{P}$ & $P$ & $P$ & $\mathrm{P}$ & $P$ & $P$ & $\mathrm{P}$ & $P$ & $P$ & $P$ & $\mathrm{P}$ & $P$ \\
\hline E.F.Z. & V & 12,5 & $\mathrm{~F}$ & - & $P$ & $P$ & $\mathrm{P}$ & $P$ & $P$ & $P$ & $\mathrm{P}$ & $\mathrm{P}$ & - & $P$ & $\mathrm{P}$ & $\mathrm{P}$ & - \\
\hline M.G.T. & $\mathrm{V}$ & 12,7 & $\mathrm{M}$ & $\mathrm{P}$ & $\mathrm{P}$ & $\mathrm{P}$ & $\mathrm{P}$ & $\mathrm{P}$ & $\mathrm{P}$ & $\mathrm{P}$ & $\mathrm{P}$ & $\mathrm{P}$ & $\mathrm{P}$ & $\mathrm{P}$ & $\mathrm{P}$ & $\mathrm{P}$ & $\mathrm{P}$ \\
\hline R.T.D.G. & $\mathrm{V}$ & 12,7 & $\bar{M}$ & $\mathrm{P}$ & $\mathrm{P}$ & $\mathrm{P}$ & $\mathrm{P}$ & $\mathrm{P}$ & $\mathrm{P}$ & $\mathrm{P}$ & $\mathrm{P}$ & $\mathrm{P}$ & $\mathrm{P}$ & $P$ & $\mathrm{P}$ & $\mathrm{P}$ & $\mathrm{P}$ \\
\hline G.C.T.N. & $\mathrm{V}$ & 12,0 & $M$ & - & $\mathrm{P}$ & $\mathrm{P}$ & $\mathrm{P}$ & $\mathrm{P}$ & $\mathrm{P}$ & $\mathrm{P}$ & $\mathrm{P}$ & $\mathrm{P}$ & $\mathrm{P}$ & $\mathrm{P}$ & $\mathrm{P}$ & $\mathrm{P}$ & - \\
\hline E.L.C.S. & $\mathrm{V}$ & 12,0 & $\mathrm{M}$ & $\mathrm{P}$ & $\mathrm{P}$ & $\mathrm{P}$ & $\mathrm{P}$ & $\mathrm{P}$ & $\mathrm{P}$ & $\mathrm{P}$ & $\mathrm{P}$ & $\mathrm{P}$ & $\mathrm{P}$ & $\mathrm{P}$ & $\mathrm{P}$ & $\mathrm{P}$ & $P$ \\
\hline M.S. & $\mathrm{V}$ & 12,2 & $\mathrm{M}$ & $\mathrm{P}$ & $P$ & $\mathrm{P}$ & $\mathrm{P}$ & $\mathrm{P}$ & $\mathrm{P}$ & $\mathrm{P}$ & $\mathrm{P}$ & $\mathrm{P}$ & $\mathrm{P}$ & $P$ & $\mathrm{P}$ & $\mathrm{P}$ & $P$ \\
\hline G.S.M. & $\mathrm{V}$ & 12,5 & $\mathrm{M}$ & $P$ & $\mathrm{P}$ & $\mathrm{P}$ & $\mathrm{P}$ & $\mathrm{P}$ & $\mathrm{P}$ & $\mathrm{P}$ & $\mathrm{P}$ & $\mathrm{P}$ & $P$ & $\mathrm{P}$ & $\mathrm{P}$ & $\mathrm{P}$ & $\mathrm{P}$ \\
\hline R.C.L.A. & V & 12,3 & $\mathrm{~F}$ & $\mathrm{P}$ & $\mathrm{P}$ & $\mathrm{P}$ & $\mathrm{P}$ & $\mathrm{P}$ & $\mathrm{P}$ & $\mathrm{P}$ & $\mathrm{P}$ & $\mathrm{P}$ & $\mathrm{P}$ & $\mathrm{P}$ & $\mathrm{P}$ & $\mathrm{P}$ & $P$ \\
\hline A.G.M. & $\mathrm{V}$ & 12,7 & $M$ & - & $\mathrm{P}$ & $\mathrm{P}$ & $\mathrm{P}$ & $\mathrm{P}$ & $\mathrm{P}$ & $\mathrm{P}$ & $P$ & $\mathrm{P}$ & $\mathrm{P}$ & $\mathrm{P}$ & $P$ & $\mathrm{P}$ & - \\
\hline D.C.G.O. & $\mathrm{V}$ & 12,3 & $\mathrm{~F}$ & $P$ & $\mathrm{P}$ & $\mathrm{P}$ & $P$ & $\mathrm{P}$ & $\mathrm{P}$ & $P$ & $\mathrm{P}$ & $\mathrm{P}$ & $\mathrm{P}$ & $P$ & $\mathrm{P}$ & $\mathrm{P}$ & $P$ \\
\hline F.C.B. & $\mathrm{V}$ & 12,5 & $\mathrm{~F}$ & $\mathrm{P}$ & $\mathrm{P}$ & $\mathrm{P}$ & $\mathrm{P}$ & $\mathrm{P}$ & $\mathrm{P}$ & $\mathrm{P}$ & $\mathrm{P}$ & $\mathrm{P}$ & $\mathrm{P}$ & $P$ & $\mathrm{P}$ & $\mathrm{P}$ & $\mathrm{P}$ \\
\hline F.L.B. & $\mathrm{V}$ & 12,4 & $\mathrm{~F}$ & - & $\mathrm{P}$ & $\mathrm{P}$ & $\mathrm{P}$ & $\mathrm{P}$ & $\mathrm{P}$ & $\mathrm{P}$ & $\mathrm{P}$ & $\mathrm{P}$ & $\mathrm{P}$ & $\mathrm{P}$ & $\mathrm{P}$ & $\mathrm{P}$ & - \\
\hline A.P.B. & $\mathrm{V}$ & 12,6 & $F$ & $\mathrm{P}$ & $\mathrm{P}$ & $\mathrm{P}$ & $\mathrm{P}$ & $\mathrm{P}$ & $\mathrm{P}$ & $\mathrm{P}$ & $\mathrm{P}$ & $\mathrm{P}$ & $\mathrm{P}$ & $\mathrm{P}$ & $\mathrm{P}$ & $\mathrm{P}$ & $\mathrm{P}$ \\
\hline C.C.P. & $\mathrm{V}$ & 12,4 & $\mathrm{~F}$ & $P$ & $\mathrm{P}$ & $\mathrm{P}$ & $P$ & $\mathrm{P}$ & $\mathrm{P}$ & $P$ & $P$ & $P$ & $P$ & $P$ & $\mathrm{P}$ & $P$ & $P$ \\
\hline F.Z. & $\mathrm{V}$ & 12,6 & $\mathrm{M}$ & $\mathrm{P}$ & $\mathrm{P}$ & $\mathrm{P}$ & $\mathrm{P}$ & $\mathrm{P}$ & $\mathrm{P}$ & $\mathrm{P}$ & $\mathrm{P}$ & $\mathrm{P}$ & $\mathrm{P}$ & $\mathrm{P}$ & $\mathrm{P}$ & $\mathrm{P}$ & $P$ \\
\hline A.C.D. & $\mathrm{H}$ & 12,8 & $\mathrm{~F}$ & $\mathrm{P}$ & $\mathrm{P}$ & $\mathrm{P}$ & $\mathrm{P}$ & $\mathrm{P}$ & $\mathrm{P}$ & $\mathrm{P}$ & $\mathrm{P}$ & $\mathrm{P}$ & $P$ & $P$ & $\mathrm{P}$ & $\mathrm{P}$ & $P$ \\
\hline E.C.L. & $\mathrm{H}$ & 12,0 & $F$ & $P$ & $P$ & $\mathrm{P}$ & $P$ & $\mathrm{P}$ & $\mathrm{P}$ & $\mathrm{P}$ & $\mathrm{P}$ & $\mathrm{P}$ & $P$ & $\mathrm{P}$ & $\mathrm{P}$ & $\mathrm{P}$ & $P$ \\
\hline R.F.E. & $\bar{H}$ & 12,0 & $\mathrm{M}$ & $\mathrm{P}$ & $\mathrm{P}$ & $\mathrm{P}$ & $\mathrm{P}$ & $\mathrm{P}$ & $\mathrm{P}$ & $\mathrm{P}$ & $\mathrm{P}$ & $\mathrm{P}$ & $\mathrm{P}$ & $\mathrm{P}$ & $\mathrm{P}$ & $\mathrm{P}$ & $\mathrm{P}$ \\
\hline S.T.G. & $\mathrm{H}$ & 12,5 & $M$ & - & $\mathrm{P}$ & $\mathrm{P}$ & $\mathrm{P}$ & $\mathrm{P}$ & $\mathrm{P}$ & $\mathrm{P}$ & $P$ & $\mathrm{P}$ & $\mathrm{P}$ & $\mathrm{P}$ & $\mathrm{P}$ & $\mathrm{P}$ & - \\
\hline J.A.R.C.M. & $\mathrm{H}$ & 12,9 & $\mathrm{M}$ & - & $P$ & $\mathrm{P}$ & $P$ & $\mathrm{P}$ & $P$ & $\mathrm{P}$ & $P$ & $P$ & - & - & - & $P$ & - \\
\hline B.M.L. & $\mathrm{H}$ & 12,2 & $M$ & - & $\mathrm{P}$ & $\mathrm{P}$ & $\mathrm{P}$ & $\mathrm{P}$ & $\mathrm{P}$ & $\mathrm{P}$ & $\mathrm{P}$ & $\mathrm{P}$ & $\mathrm{P}$ & $\mathrm{P}$ & $\mathrm{P}$ & $\mathrm{P}$ & - \\
\hline R.O.B.A. & $\mathrm{H}$ & 12,5 & $\mathrm{M}$ & - & $\mathrm{P}$ & $\mathrm{P}$ & $\mathrm{P}$ & $\mathrm{P}$ & $\mathrm{P}$ & $\mathrm{P}$ & $\mathrm{P}$ & $\mathrm{P}$ & $\mathrm{P}$ & $\mathrm{P}$ & $\mathrm{P}$ & $\mathrm{P}$ & - \\
\hline C.F.Z.S. & $\mathrm{H}$ & 12,0 & $\mathrm{~F}$ & $\mathrm{P}$ & $\mathrm{P}$ & $\mathrm{P}$ & $\mathrm{P}$ & $\mathrm{P}$ & $P$ & $\mathrm{P}$ & $\mathrm{P}$ & $\mathrm{P}$ & $P$ & $\mathrm{P}$ & $\mathrm{P}$ & $\mathrm{P}$ & $P$ \\
\hline M.P.P. & $\mathrm{H}$ & 12,5 & $F$ & - & $\mathrm{P}$ & - & $\mathrm{P}$ & $\mathrm{P}$ & $\mathrm{P}$ & $\mathrm{P}$ & $\mathrm{P}$ & $\mathrm{P}$ & $\mathrm{P}$ & $\mathrm{P}$ & $\mathrm{P}$ & $\mathrm{P}$ & $\mathrm{P}$ \\
\hline C.L.C. & $\overline{\mathrm{H}}$ & 12,3 & $\mathrm{~F}$ & $P$ & $\mathrm{P}$ & $\mathrm{P}$ & $\mathrm{P}$ & $\mathrm{P}$ & $\mathrm{P}$ & $\mathrm{P}$ & $P$ & $\mathrm{P}$ & $\mathrm{P}$ & $\mathrm{P}$ & $\mathrm{P}$ & $\mathrm{P}$ & $\mathrm{P}$ \\
\hline T.S.N.J. & $\bar{H}$ & 12,6 & $M$ & $\mathrm{P}$ & $\mathrm{P}$ & $\mathrm{P}$ & $P$ & $\mathrm{P}$ & $\mathrm{P}$ & $\mathrm{P}$ & $\mathrm{P}$ & $P$ & $\mathrm{P}$ & $\mathrm{P}$ & $\mathrm{P}$ & $\mathrm{P}$ & $\mathrm{P}$ \\
\hline J.A.A.C. & $\mathrm{H}$ & 12,8 & $\mathrm{M}$ & $P$ & $P$ & $\mathrm{P}$ & $P$ & $\mathrm{P}$ & $P$ & $\mathrm{P}$ & $P$ & $\mathrm{P}$ & $P$ & $\mathrm{P}$ & $P$ & $\mathrm{P}$ & $P$ \\
\hline P.B.B.M. & $\mathrm{H}$ & 12,9 & $\mathrm{~F}$ & $\mathrm{P}$ & $P$ & $\mathrm{P}$ & $\mathrm{P}$ & $\mathrm{P}$ & $\mathrm{P}$ & $\mathrm{P}$ & $\mathrm{P}$ & $\mathrm{P}$ & $\mathrm{P}$ & $\mathrm{P}$ & $\mathrm{P}$ & $\mathrm{P}$ & $\mathrm{P}$ \\
\hline M.H.T. & $\mathrm{H}$ & 12,2 & $\mathrm{~F}$ & - & $\mathrm{P}$ & - & $\mathrm{P}$ & $\mathrm{P}$ & $\mathrm{P}$ & $\mathrm{P}$ & $\mathrm{P}$ & $\mathrm{P}$ & $\mathrm{P}$ & $\mathrm{P}$ & - & $\mathrm{P}$ & - \\
\hline F.B. & $\mathrm{H}$ & 12,5 & $\mathrm{~F}$ & $P$ & $P$ & $\mathrm{P}$ & $\mathrm{P}$ & $\mathrm{P}$ & $P$ & $\mathrm{P}$ & $\mathrm{P}$ & $\mathrm{P}$ & $P$ & $\mathrm{P}$ & $\mathrm{P}$ & $\mathrm{P}$ & $P$ \\
\hline A.B.S.M. & $\mathrm{H}$ & 12,0 & $\mathrm{~F}$ & - & $\mathrm{P}$ & - & $\mathrm{P}$ & - & $\mathrm{P}$ & $\mathrm{P}$ & $\mathrm{P}$ & $\mathrm{P}$ & - & - & - & $\mathrm{P}$ & - \\
\hline C.B.J. & $\mathrm{H}$ & 12,5 & $\mathrm{~F}$ & $\mathrm{P}$ & $\mathrm{P}$ & $\mathrm{P}$ & $\mathrm{P}$ & $\mathrm{P}$ & $\mathrm{P}$ & $\mathrm{P}$ & $\mathrm{P}$ & $\mathrm{P}$ & $\mathrm{P}$ & $\mathrm{P}$ & $\mathrm{P}$ & $\mathrm{P}$ & $\mathrm{P}$ \\
\hline D.E.H. & $\overline{\mathrm{H}}$ & 12,6 & $\mathrm{~F}$ & $\mathrm{P}$ & $P$ & $\mathrm{P}$ & $\mathrm{P}$ & $\mathrm{P}$ & $\mathrm{P}$ & $\mathrm{P}$ & $P$ & $\mathrm{P}$ & $\mathrm{P}$ & $\mathrm{P}$ & $\mathrm{P}$ & $\mathrm{P}$ & $\mathrm{P}$ \\
\hline D.A.M. & $\mathrm{H}$ & 12,5 & $\mathrm{M}$ & $\mathrm{P}$ & $\mathrm{P}$ & $\mathrm{P}$ & $\mathrm{P}$ & - & $\mathrm{P}$ & $\mathrm{P}$ & $\mathrm{P}$ & $\mathrm{P}$ & $\mathrm{P}$ & $\mathrm{P}$ & $\mathrm{P}$ & $\mathrm{P}$ & $\mathrm{P}$ \\
\hline M.L.P. & $\mathrm{H}$ & 12,0 & $\mathrm{~F}$ & $\mathrm{P}$ & $\mathrm{P}$ & $\mathrm{P}$ & $\mathrm{P}$ & $\mathrm{P}$ & $\mathrm{P}$ & $\mathrm{P}$ & $\mathrm{P}$ & $\mathrm{P}$ & $\mathrm{P}$ & $\mathrm{P}$ & $\mathrm{P}$ & $\mathrm{P}$ & $\mathrm{P}$ \\
\hline L.B. & $\overline{\mathrm{H}}$ & 12,6 & $\mathrm{~F}$ & $\mathrm{P}$ & $\mathrm{P}$ & $\mathrm{P}$ & $\mathrm{P}$ & $\mathrm{P}$ & $\mathrm{P}$ & $\mathrm{P}$ & $P$ & $\mathrm{P}$ & $\mathrm{P}$ & $\mathrm{P}$ & $P$ & $\mathrm{P}$ & $\mathrm{P}$ \\
\hline A.P.M.B. & $\mathrm{H}$ & 12,0 & $\mathrm{~F}$ & $\mathrm{P}$ & $\mathrm{P}$ & $\mathrm{P}$ & $\mathrm{P}$ & $\mathrm{P}$ & $\mathrm{P}$ & $\mathrm{P}$ & $\mathrm{P}$ & $\mathrm{P}$ & $\mathrm{P}$ & $\mathrm{P}$ & $\mathrm{P}$ & $\mathrm{P}$ & $\mathrm{P}$ \\
\hline P.S.E. & $\mathrm{H}$ & 12,5 & $\mathrm{~F}$ & $\mathrm{P}$ & $\mathrm{P}$ & $\mathrm{P}$ & $\mathrm{P}$ & - & $\mathrm{P}$ & $\mathrm{P}$ & $\mathrm{P}$ & $\mathrm{P}$ & $\mathrm{P}$ & $\mathrm{P}$ & $\mathrm{P}$ & $\mathrm{P}$ & $\mathrm{P}$ \\
\hline J.R.N. & $\mathrm{H}$ & 12,9 & $\mathrm{M}$ & $\mathrm{P}$ & $\mathrm{P}$ & $\mathrm{P}$ & $\mathrm{P}$ & $\mathrm{P}$ & $\mathrm{P}$ & $\mathrm{P}$ & $\mathrm{P}$ & $\mathrm{P}$ & $\mathrm{P}$ & $\mathrm{P}$ & $\mathrm{P}$ & $\mathrm{P}$ & $\mathrm{P}$ \\
\hline E.A. & $\mathrm{H}$ & 12,8 & $M$ & $\mathrm{P}$ & $\mathrm{P}$ & $\mathrm{P}$ & $\mathrm{P}$ & $\mathrm{P}$ & $\mathrm{P}$ & $\mathrm{P}$ & $\mathrm{P}$ & $\mathrm{P}$ & $\mathrm{P}$ & $\mathrm{P}$ & $\mathrm{P}$ & $\mathrm{P}$ & $\mathrm{P}$ \\
\hline C.S.D. & $\mathrm{H}$ & 12,0 & $\mathrm{~F}$ & $\mathrm{P}$ & $\mathrm{P}$ & $\mathrm{P}$ & $\mathrm{P}$ & $\mathrm{P}$ & $\mathrm{P}$ & $\mathrm{P}$ & $P$ & $\mathrm{P}$ & $\mathrm{P}$ & $\mathrm{P}$ & $\mathrm{P}$ & $\mathrm{P}$ & $\mathrm{P}$ \\
\hline R.V.D. & $\mathrm{H}$ & 12,1 & $\mathrm{M}$ & $\mathrm{P}$ & $\mathrm{P}$ & $\mathrm{P}$ & $\mathrm{P}$ & $\mathrm{P}$ & $\mathrm{P}$ & $\mathrm{P}$ & $\mathrm{P}$ & $\mathrm{P}$ & $\mathrm{P}$ & $\mathrm{P}$ & $\mathrm{P}$ & $\mathrm{P}$ & $\mathrm{P}$ \\
\hline G.R.P. & $\overline{\mathrm{H}}$ & 12,3 & $\mathrm{~F}$ & $P$ & $P$ & $P$ & $\mathrm{P}$ & $\mathrm{P}$ & $P$ & $\mathrm{P}$ & $P$ & $P$ & $\mathrm{P}$ & $\mathrm{P}$ & $P$ & $\mathrm{P}$ & $\mathrm{P}$ \\
\hline I.M.L. & $\mathrm{H}$ & 12,5 & $\mathrm{~F}$ & $P$ & $P$ & $P$ & $P$ & $P$ & $P$ & $\mathrm{P}$ & $P$ & $P$ & $P$ & $P$ & $P$ & $P$ & $P$ \\
\hline F.R.O. & $\mathrm{H}$ & 12,0 & $\mathrm{M}$ & - & $\mathrm{P}$ & $\mathrm{P}$ & $\mathrm{P}$ & - & $\mathrm{P}$ & $\mathrm{P}$ & $P$ & $\mathrm{P}$ & - & $\mathrm{P}$ & $P$ & $\mathrm{P}$ & - \\
\hline
\end{tabular}


Tabela A-19

\begin{tabular}{|c|c|c|c|c|c|c|c|c|c|c|c|c|c|c|c|c|c|}
\hline Nome & Grupo & Idade & Gênero & 37 & 36 & 35 & 34 & 33 & 32 & 31 & 41 & 42 & 43 & 44 & 45 & 46 & 47 \\
\hline A.C.M. & V & 12,5 & $\mathrm{~F}$ & $\mathrm{P}$ & $\mathrm{P}$ & $\mathrm{P}$ & $\mathrm{P}$ & $\mathrm{P}$ & $\mathrm{P}$ & $\mathrm{P}$ & $\mathrm{P}$ & $\mathrm{P}$ & $\mathrm{P}$ & $\mathrm{P}$ & $\mathrm{P}$ & $\mathrm{P}$ & $\mathrm{P}$ \\
\hline P.S.P.C. & $\mathrm{V}$ & 12,4 & $\mathrm{M}$ & $\mathrm{P}$ & $\mathrm{P}$ & $\mathrm{P}$ & $\mathrm{P}$ & $\mathrm{P}$ & $\mathrm{P}$ & $\mathrm{P}$ & $P$ & $\mathrm{P}$ & $\mathrm{P}$ & $P$ & $\mathrm{P}$ & $\mathrm{P}$ & $\mathrm{P}$ \\
\hline E.C.M. & $\mathrm{V}$ & 12,0 & $\mathrm{~F}$ & $\mathrm{P}$ & $\mathrm{P}$ & $\mathrm{P}$ & $\mathrm{P}$ & $\mathrm{P}$ & $\mathrm{P}$ & $\mathrm{P}$ & $P$ & $\mathrm{P}$ & $\mathrm{P}$ & $P$ & $\mathrm{P}$ & $\mathrm{P}$ & $\mathrm{P}$ \\
\hline J.C.M.J. & $\mathrm{V}$ & 12,0 & $\mathrm{M}$ & - & $\mathrm{P}$ & - & - & - & $\mathrm{P}$ & $\mathrm{P}$ & $\mathrm{P}$ & $\mathrm{P}$ & $\mathrm{P}$ & $P$ & $\mathrm{P}$ & $\mathrm{P}$ & - \\
\hline M.A.P.T. & $\mathrm{V}$ & 12,0 & $\mathrm{M}$ & $\mathrm{P}$ & $\mathrm{P}$ & $\mathrm{P}$ & $\mathrm{P}$ & $\mathrm{P}$ & $\mathrm{P}$ & $\mathrm{P}$ & $P$ & $\mathrm{P}$ & $\mathrm{P}$ & $P$ & $\mathrm{P}$ & $\mathrm{P}$ & $\mathrm{P}$ \\
\hline P.B.J. & $\mathrm{V}$ & 12,8 & $M$ & $\mathrm{P}$ & $\mathrm{P}$ & $\mathrm{P}$ & $\mathrm{P}$ & $\mathrm{P}$ & $P$ & $\mathrm{P}$ & $P$ & $P$ & $P$ & $P$ & $\mathrm{P}$ & $\mathrm{P}$ & $\mathrm{P}$ \\
\hline R.G.M. & V & 12,2 & $M$ & $\mathrm{P}$ & $\mathrm{P}$ & $\mathrm{P}$ & $\mathrm{P}$ & $\mathrm{P}$ & $\mathrm{P}$ & $\mathrm{P}$ & $P$ & $P$ & $\mathrm{P}$ & $P$ & $\mathrm{P}$ & $\mathrm{P}$ & $\mathrm{P}$ \\
\hline T.C.C.C. & V & 12,0 & $\mathrm{~F}$ & $\mathrm{P}$ & $\mathrm{P}$ & $\mathrm{P}$ & $\mathrm{P}$ & $\mathrm{P}$ & $\mathrm{P}$ & $\mathrm{P}$ & $P$ & $\mathrm{P}$ & $P$ & $P$ & $\mathrm{P}$ & $\mathrm{P}$ & $\mathrm{P}$ \\
\hline M.Q.B. & $\mathrm{V}$ & 12,0 & $\mathrm{M}$ & $P$ & $P$ & $\mathrm{P}$ & $\mathrm{P}$ & $P$ & $P$ & $P$ & $P$ & $P$ & $P$ & $P$ & $\mathrm{P}$ & $P$ & $\mathrm{P}$ \\
\hline R.A.S.S. & $\mathrm{V}$ & 12,4 & $\mathrm{~F}$ & - & $\mathrm{P}$ & $\mathrm{P}$ & $\mathrm{P}$ & $\mathrm{P}$ & $\mathrm{P}$ & $\mathrm{P}$ & $P$ & $P$ & $\mathrm{P}$ & - & $\mathrm{P}$ & $\mathrm{P}$ & - \\
\hline R.B.R. & V & 12,2 & $\mathrm{~F}$ & - & $\mathrm{P}$ & $\mathrm{P}$ & $\mathrm{P}$ & $P$ & $P$ & $\mathrm{P}$ & $P$ & $\mathrm{P}$ & $P$ & $\mathrm{P}$ & $\mathrm{P}$ & $\mathrm{P}$ & - \\
\hline F.B.A. & $\mathrm{V}$ & 12,4 & $\mathrm{~F}$ & $\mathrm{P}$ & $\mathrm{P}$ & $P$ & $\mathrm{P}$ & $\mathrm{P}$ & $\mathrm{P}$ & $\mathrm{P}$ & $P$ & $P$ & $P$ & $P$ & $\mathrm{P}$ & $\mathrm{P}$ & - \\
\hline M.F.G. & $\mathrm{V}$ & 12,0 & $\mathrm{~F}$ & $\mathrm{P}$ & $\mathrm{P}$ & $P$ & $P$ & $\mathrm{P}$ & $\mathrm{P}$ & $\mathrm{P}$ & $P$ & $P$ & $P$ & $P$ & $\mathrm{P}$ & $\mathrm{P}$ & $P$ \\
\hline E.F.Z. & V & 12,5 & $\mathrm{~F}$ & $P$ & $\mathrm{P}$ & $\mathrm{P}$ & $P$ & $\mathrm{P}$ & $P$ & $\mathrm{P}$ & $P$ & $P$ & $P$ & $P$ & $\mathrm{P}$ & $\mathrm{P}$ & - \\
\hline M.G.T. & $\mathrm{V}$ & 12,7 & $\mathrm{M}$ & $\mathrm{P}$ & $\mathrm{P}$ & $\mathrm{P}$ & $\mathrm{P}$ & $\mathrm{P}$ & $\mathrm{P}$ & $\mathrm{P}$ & $P$ & $\mathrm{P}$ & $\mathrm{P}$ & $\mathrm{P}$ & $\mathrm{P}$ & $\mathrm{P}$ & $\mathrm{P}$ \\
\hline R.T.D.G. & $\mathrm{V}$ & 12,7 & $\bar{M}$ & $\mathrm{P}$ & $\mathrm{P}$ & $\mathrm{P}$ & $P$ & $\mathrm{P}$ & $\mathrm{P}$ & $\mathrm{P}$ & $P$ & $P$ & $\mathrm{P}$ & $P$ & $\mathrm{P}$ & $\mathrm{P}$ & $\mathrm{P}$ \\
\hline G.C.T.N. & $\mathrm{V}$ & 12,0 & $M$ & - & $\mathrm{P}$ & $\mathrm{P}$ & $\mathrm{P}$ & $\mathrm{P}$ & $\mathrm{P}$ & $\mathrm{P}$ & $P$ & $\mathrm{P}$ & $\mathrm{P}$ & $\mathrm{P}$ & $\mathrm{P}$ & $\mathrm{P}$ & - \\
\hline E.L.C.S. & $\mathrm{V}$ & 12,0 & $\mathrm{M}$ & $\mathrm{P}$ & $\mathrm{P}$ & $\mathrm{P}$ & $\mathrm{P}$ & $\mathrm{P}$ & $\mathrm{P}$ & $\mathrm{P}$ & $P$ & $\mathrm{P}$ & $\mathrm{P}$ & $\mathrm{P}$ & $\mathrm{P}$ & $\mathrm{P}$ & $P$ \\
\hline M.S. & $\mathrm{V}$ & 12,2 & $\mathrm{M}$ & $\mathrm{P}$ & $\mathrm{P}$ & $\mathrm{P}$ & $P$ & $\mathrm{P}$ & $\mathrm{P}$ & $P$ & $P$ & $P$ & $\mathrm{P}$ & $\mathrm{P}$ & $\mathrm{P}$ & $\mathrm{P}$ & $P$ \\
\hline G.S.M. & $\mathrm{V}$ & 12,5 & $\mathrm{M}$ & $\mathrm{P}$ & $\mathrm{P}$ & $P$ & $\mathrm{P}$ & $\mathrm{P}$ & $\mathrm{P}$ & $\mathrm{P}$ & $\mathrm{P}$ & $\mathrm{P}$ & $\mathrm{P}$ & $P$ & $\mathrm{P}$ & $\mathrm{P}$ & $\mathrm{P}$ \\
\hline R.C.L.A. & V & 12,3 & $\mathrm{~F}$ & $\mathrm{P}$ & $\mathrm{P}$ & $\mathrm{P}$ & $\mathrm{P}$ & $\mathrm{P}$ & $\mathrm{P}$ & $\mathrm{P}$ & $P$ & $\mathrm{P}$ & $\mathrm{P}$ & $\mathrm{P}$ & $\mathrm{P}$ & $\mathrm{P}$ & $P$ \\
\hline A.G.M. & $\mathrm{V}$ & 12,7 & $M$ & - & $\mathrm{P}$ & $\mathrm{P}$ & $\mathrm{P}$ & $\mathrm{P}$ & $\mathrm{P}$ & $\mathrm{P}$ & $\mathrm{P}$ & $\mathrm{P}$ & $\mathrm{P}$ & $\mathrm{P}$ & $\mathrm{P}$ & $\mathrm{P}$ & - \\
\hline D.C.G.O. & $\mathrm{V}$ & 12,3 & $\mathrm{~F}$ & $\mathrm{P}$ & $\mathrm{P}$ & $P$ & $\bar{P}$ & $\mathrm{P}$ & $\mathrm{P}$ & $\mathrm{P}$ & $P$ & $\bar{P}$ & $\mathrm{P}$ & $P$ & $\mathrm{P}$ & $\mathrm{P}$ & $P$ \\
\hline F.C.B. & $\mathrm{V}$ & 12,5 & $\mathrm{~F}$ & $\mathrm{P}$ & $\mathrm{P}$ & $\mathrm{P}$ & $\mathrm{P}$ & $\mathrm{P}$ & $\mathrm{P}$ & $\mathrm{P}$ & $P$ & $\mathrm{P}$ & $\mathrm{P}$ & $\mathrm{P}$ & $\mathrm{P}$ & $\mathrm{P}$ & $\mathrm{P}$ \\
\hline F.L.B. & $\mathrm{V}$ & 12,4 & $\mathrm{~F}$ & - & $\mathrm{P}$ & $\mathrm{P}$ & $\mathrm{P}$ & $\mathrm{P}$ & $\mathrm{P}$ & $\mathrm{P}$ & $P$ & $\mathrm{P}$ & $\mathrm{P}$ & $\mathrm{P}$ & $\mathrm{P}$ & $\mathrm{P}$ & - \\
\hline A.P.B. & $\mathrm{V}$ & 12,6 & $F$ & $\mathrm{P}$ & $\mathrm{P}$ & $\mathrm{P}$ & $\mathrm{P}$ & $\mathrm{P}$ & $\mathrm{P}$ & $\mathrm{P}$ & $P$ & $\mathrm{P}$ & $\mathrm{P}$ & $\mathrm{P}$ & $\mathrm{P}$ & $\mathrm{P}$ & $\mathrm{P}$ \\
\hline C.C.P. & $\mathrm{V}$ & 12,4 & $\mathrm{~F}$ & $\mathrm{P}$ & $\mathrm{P}$ & $\mathrm{P}$ & $\mathrm{P}$ & $\mathrm{P}$ & $\mathrm{P}$ & $\mathrm{P}$ & $P$ & $\mathrm{P}$ & $\mathrm{P}$ & $P$ & $\mathrm{P}$ & $\mathrm{P}$ & $P$ \\
\hline F.Z. & V & 12,6 & $\mathrm{M}$ & $\mathrm{P}$ & $\mathrm{P}$ & $\mathrm{P}$ & $\mathrm{P}$ & $\mathrm{P}$ & $\mathrm{P}$ & $\mathrm{P}$ & $P$ & $\mathrm{P}$ & $\mathrm{P}$ & $\mathrm{P}$ & $\mathrm{P}$ & $\mathrm{P}$ & $P$ \\
\hline A.C.D. & $\mathrm{H}$ & 12,8 & $\mathrm{~F}$ & $\mathrm{P}$ & $\mathrm{P}$ & $\mathrm{P}$ & $\mathrm{P}$ & $\mathrm{P}$ & $\mathrm{P}$ & $\mathrm{P}$ & $P$ & $\mathrm{P}$ & $\mathrm{P}$ & $\mathrm{P}$ & $\mathrm{P}$ & $\mathrm{P}$ & $P$ \\
\hline E.C.L. & $\mathrm{H}$ & 12,0 & $\mathrm{~F}$ & $\mathrm{P}$ & $\mathrm{P}$ & $P$ & $\mathrm{P}$ & $\mathrm{P}$ & $\mathrm{P}$ & $\mathrm{P}$ & $P$ & $P$ & $P$ & $P$ & $\mathrm{P}$ & $\mathrm{P}$ & $P$ \\
\hline R.F.E. & $\mathrm{H}$ & 12,0 & $\mathrm{M}$ & $\mathrm{P}$ & $\mathrm{P}$ & $\mathrm{P}$ & $\mathrm{P}$ & $\mathrm{P}$ & $\mathrm{P}$ & $\mathrm{P}$ & $\mathrm{P}$ & $\mathrm{P}$ & $\mathrm{P}$ & $\mathrm{P}$ & $\mathrm{P}$ & $\mathrm{P}$ & $\mathrm{P}$ \\
\hline S.T.G. & $\mathrm{H}$ & 12,5 & $M$ & - & $\mathrm{P}$ & $\mathrm{P}$ & $\mathrm{P}$ & $\mathrm{P}$ & $\mathrm{P}$ & $\mathrm{P}$ & $\mathrm{P}$ & $\mathrm{P}$ & $\mathrm{P}$ & $P$ & $\mathrm{P}$ & $\mathrm{P}$ & - \\
\hline J.A.R.C.M. & $\mathrm{H}$ & 12,9 & $\mathrm{M}$ & $P$ & $P$ & $P$ & $\mathrm{P}$ & $\mathrm{P}$ & $P$ & $\mathrm{P}$ & $P$ & $P$ & $P$ & $P$ & $P$ & $P$ & $P$ \\
\hline B.M.L. & $\mathrm{H}$ & 12,2 & $M$ & $\mathrm{P}$ & $\mathrm{P}$ & $\mathrm{P}$ & $\mathrm{P}$ & $\mathrm{P}$ & $\mathrm{P}$ & $\mathrm{P}$ & $\mathrm{P}$ & $\mathrm{P}$ & $\mathrm{P}$ & $\mathrm{P}$ & $\mathrm{P}$ & $\mathrm{P}$ & $P$ \\
\hline R.O.B.A. & $\overline{\mathrm{H}}$ & 12,5 & $\mathrm{M}$ & $\mathrm{P}$ & $\mathrm{P}$ & $\mathrm{P}$ & $\mathrm{P}$ & $\mathrm{P}$ & $\mathrm{P}$ & $\mathrm{P}$ & $\mathrm{P}$ & $\mathrm{P}$ & $\mathrm{P}$ & $\mathrm{P}$ & $\mathrm{P}$ & $\mathrm{P}$ & $P$ \\
\hline C.F.Z.S. & $\mathrm{H}$ & 12,0 & $\mathrm{~F}$ & $\mathrm{P}$ & $\mathrm{P}$ & $P$ & $\mathrm{P}$ & $\mathrm{P}$ & $\mathrm{P}$ & $\mathrm{P}$ & $P$ & $\mathrm{P}$ & $\mathrm{P}$ & $P$ & $\mathrm{P}$ & $\mathrm{P}$ & $P$ \\
\hline M.P.P. & $\mathrm{H}$ & 12,5 & $F$ & $\mathrm{P}$ & $\mathrm{P}$ & - & $\mathrm{P}$ & $\mathrm{P}$ & $\mathrm{P}$ & $\mathrm{P}$ & $\mathrm{P}$ & $\mathrm{P}$ & $\mathrm{P}$ & $P$ & - & $\mathrm{P}$ & $\mathrm{P}$ \\
\hline C.L.C. & $\overline{\mathrm{H}}$ & 12,3 & $\mathrm{~F}$ & $\mathrm{P}$ & $\mathrm{P}$ & $P$ & $\mathrm{P}$ & $\mathrm{P}$ & $\mathrm{P}$ & $\mathrm{P}$ & $\mathrm{P}$ & $\mathrm{P}$ & $\mathrm{P}$ & $\mathrm{P}$ & $\mathrm{P}$ & $\mathrm{P}$ & $P$ \\
\hline T.S.N.J. & $\mathrm{H}$ & 12,6 & $M$ & - & $\mathrm{P}$ & $\mathrm{P}$ & $\mathrm{P}$ & $\mathrm{P}$ & $\mathrm{P}$ & $\mathrm{P}$ & $\mathrm{P}$ & $P$ & $P$ & $\mathrm{P}$ & $\mathrm{P}$ & $\mathrm{P}$ & - \\
\hline J.A.A.C. & $\mathrm{H}$ & 12,8 & $\mathrm{M}$ & $P$ & $P$ & $P$ & $P$ & $\mathrm{P}$ & $\mathrm{P}$ & $\mathrm{P}$ & $P$ & $P$ & $\mathrm{P}$ & $P$ & $\mathrm{P}$ & $P$ & $P$ \\
\hline P.B.B.M. & $\mathrm{H}$ & 12,9 & $\mathrm{~F}$ & $\mathrm{P}$ & $\mathrm{P}$ & $\mathrm{P}$ & $\mathrm{P}$ & $\mathrm{P}$ & $\mathrm{P}$ & $\mathrm{P}$ & $\mathrm{P}$ & $\mathrm{P}$ & $\mathrm{P}$ & $\mathrm{P}$ & $\mathrm{P}$ & $\mathrm{P}$ & $\mathrm{P}$ \\
\hline M.H.T. & $\mathrm{H}$ & 12,2 & $\mathrm{~F}$ & $\mathrm{P}$ & $\mathrm{P}$ & $\mathrm{P}$ & $\mathrm{P}$ & $\mathrm{P}$ & $\mathrm{P}$ & $\mathrm{P}$ & $\mathrm{P}$ & $\mathrm{P}$ & $\mathrm{P}$ & $\mathrm{P}$ & - & $\mathrm{P}$ & - \\
\hline F.B. & $\mathrm{H}$ & 12,5 & $\mathrm{~F}$ & $\mathrm{P}$ & $\mathrm{P}$ & $P$ & $\mathrm{P}$ & $\mathrm{P}$ & $\mathrm{P}$ & $\mathrm{P}$ & $P$ & $\mathrm{P}$ & $\mathrm{P}$ & $P$ & $P$ & $\mathrm{P}$ & $P$ \\
\hline A.B.S.M. & $\mathrm{H}$ & 12,0 & $\mathrm{~F}$ & $\mathrm{P}$ & $\mathrm{P}$ & - & $\mathrm{P}$ & $\mathrm{P}$ & $\mathrm{P}$ & $\mathrm{P}$ & $\mathrm{P}$ & $\mathrm{P}$ & $\mathrm{P}$ & $\mathrm{P}$ & - & $\mathrm{P}$ & $\mathrm{P}$ \\
\hline C.B.J. & $\mathrm{H}$ & 12,5 & $\mathrm{~F}$ & $\mathrm{P}$ & $\mathrm{P}$ & $\mathrm{P}$ & $\mathrm{P}$ & $\mathrm{P}$ & $\mathrm{P}$ & $\mathrm{P}$ & $\mathrm{P}$ & $\mathrm{P}$ & $\mathrm{P}$ & $\mathrm{P}$ & $\mathrm{P}$ & $\mathrm{P}$ & $\mathrm{P}$ \\
\hline D.E.H. & $\overline{\mathrm{H}}$ & 12,6 & $\mathrm{~F}$ & $\mathrm{P}$ & $\mathrm{P}$ & $\mathrm{P}$ & $\mathrm{P}$ & $\mathrm{P}$ & $\mathrm{P}$ & $\mathrm{P}$ & $P$ & $\mathrm{P}$ & $\mathrm{P}$ & $\mathrm{P}$ & $\mathrm{P}$ & $\mathrm{P}$ & $\mathrm{P}$ \\
\hline D.A.M. & $\overline{\mathrm{H}}$ & 12,5 & $\mathrm{M}$ & $\mathrm{P}$ & $\mathrm{P}$ & $\mathrm{P}$ & $\mathrm{P}$ & $\mathrm{P}$ & $\mathrm{P}$ & $\mathrm{P}$ & $\mathrm{P}$ & $\mathrm{P}$ & $\mathrm{P}$ & $\mathrm{P}$ & $\mathrm{P}$ & $\mathrm{P}$ & $\mathrm{P}$ \\
\hline M.L.P. & $\mathrm{H}$ & 12,0 & $\mathrm{~F}$ & $\mathrm{P}$ & $\mathrm{P}$ & $\mathrm{P}$ & $\mathrm{P}$ & $\mathrm{P}$ & $\mathrm{P}$ & $\mathrm{P}$ & $\mathrm{P}$ & $\mathrm{P}$ & $\mathrm{P}$ & $\mathrm{P}$ & $\mathrm{P}$ & $\mathrm{P}$ & $\mathrm{P}$ \\
\hline L.B. & $\overline{\mathrm{H}}$ & 12,6 & $\mathrm{~F}$ & $\mathrm{P}$ & $\mathrm{P}$ & $\mathrm{P}$ & $\mathrm{P}$ & $\mathrm{P}$ & $\mathrm{P}$ & $\mathrm{P}$ & $P$ & $\mathrm{P}$ & $\mathrm{P}$ & $\mathrm{P}$ & $\mathrm{P}$ & $\mathrm{P}$ & $\mathrm{P}$ \\
\hline A.P.M.B. & $\mathrm{H}$ & 12,0 & $\mathrm{~F}$ & $\mathrm{P}$ & $\mathrm{P}$ & $\mathrm{P}$ & $\mathrm{P}$ & $\mathrm{P}$ & $\mathrm{P}$ & $\mathrm{P}$ & $P$ & $\mathrm{P}$ & $\mathrm{P}$ & $\mathrm{P}$ & $\mathrm{P}$ & $\mathrm{P}$ & $\mathrm{P}$ \\
\hline P.S.E. & $\mathrm{H}$ & 12,5 & $\mathrm{~F}$ & $\mathrm{P}$ & $\mathrm{P}$ & - & $\mathrm{P}$ & $\mathrm{P}$ & $\mathrm{P}$ & $\mathrm{P}$ & $\mathrm{P}$ & $\mathrm{P}$ & $\mathrm{P}$ & $\mathrm{P}$ & $\mathrm{P}$ & $\mathrm{P}$ & $\mathrm{P}$ \\
\hline J.R.N. & $\overline{\mathrm{H}}$ & 12,9 & $\mathrm{M}$ & $\mathrm{P}$ & $\mathrm{P}$ & $\mathrm{P}$ & $\mathrm{P}$ & $\mathrm{P}$ & $\mathrm{P}$ & $\mathrm{P}$ & $P$ & $\mathrm{P}$ & $\mathrm{P}$ & $\mathrm{P}$ & $\mathrm{P}$ & $\mathrm{P}$ & $\mathrm{P}$ \\
\hline E.A. & $\mathrm{H}$ & 12,8 & $M$ & $\mathrm{P}$ & $\mathrm{P}$ & $\mathrm{P}$ & $\mathrm{P}$ & $\mathrm{P}$ & $\mathrm{P}$ & $\mathrm{P}$ & $P$ & $\mathrm{P}$ & $\mathrm{P}$ & $\mathrm{P}$ & $\mathrm{P}$ & $\mathrm{P}$ & $\mathrm{P}$ \\
\hline C.S.D. & $\mathrm{H}$ & 12,0 & $\mathrm{~F}$ & $\mathrm{P}$ & $\mathrm{P}$ & $\mathrm{P}$ & $\mathrm{P}$ & $\mathrm{P}$ & $\mathrm{P}$ & $\mathrm{P}$ & $P$ & $\mathrm{P}$ & $\mathrm{P}$ & $\mathrm{P}$ & $\mathrm{P}$ & $\mathrm{P}$ & $\mathrm{P}$ \\
\hline R.V.D. & $\mathrm{H}$ & 12,1 & $M$ & $\mathrm{P}$ & $\mathrm{P}$ & $\mathrm{P}$ & $\mathrm{P}$ & $\mathrm{P}$ & $\mathrm{P}$ & $\mathrm{P}$ & $P$ & $\mathrm{P}$ & $\mathrm{P}$ & $P$ & $\mathrm{P}$ & $\mathrm{P}$ & $\mathrm{P}$ \\
\hline G.R.P. & $\overline{\mathrm{H}}$ & 12,3 & $\mathrm{~F}$ & $\mathrm{P}$ & $P$ & $P$ & $\mathrm{P}$ & $\mathrm{P}$ & $P$ & $P$ & $P$ & $\mathrm{P}$ & $\mathrm{P}$ & $P$ & $P$ & $\mathrm{P}$ & $\mathrm{P}$ \\
\hline I.M.L. & $\mathrm{H}$ & 12,5 & $\mathrm{~F}$ & $\mathrm{P}$ & $P$ & $P$ & $\mathrm{P}$ & $\mathrm{P}$ & $P$ & $P$ & $\mathrm{P}$ & $\mathrm{P}$ & $P$ & $P$ & $P$ & $\mathrm{P}$ & $P$ \\
\hline F.R.O. & $\mathrm{H}$ & 12,0 & $\mathrm{M}$ & - & $\mathrm{P}$ & $\mathrm{P}$ & $\mathrm{P}$ & $\mathrm{P}$ & $\mathrm{P}$ & $\mathrm{P}$ & $P$ & $\mathrm{P}$ & $\mathrm{P}$ & $P$ & $\mathrm{P}$ & $\mathrm{P}$ & - \\
\hline
\end{tabular}


Tabela A-20

\begin{tabular}{|c|c|c|c|c|c|c|c|c|c|c|c|c|c|c|c|c|c|}
\hline Nome & Grupo & Idade & Gênero & 17 & 16 & 15 & 14 & 13 & 12 & 11 & 21 & 22 & 23 & 24 & 25 & 26 & 27 \\
\hline R.A.A. & V & 13,8 & $M$ & $\mathrm{P}$ & $\mathrm{P}$ & $\mathrm{P}$ & $\mathrm{P}$ & $\mathrm{P}$ & $P$ & $\mathrm{P}$ & $\mathrm{P}$ & $\mathrm{P}$ & $\mathrm{P}$ & $P$ & $\mathrm{P}$ & $\mathrm{P}$ & $\mathrm{P}$ \\
\hline D.F.D. & $\mathrm{V}$ & 13,1 & $\mathrm{M}$ & $\mathrm{P}$ & $\mathrm{P}$ & $P$ & $\mathrm{P}$ & $\mathrm{P}$ & $\mathrm{P}$ & $\mathrm{P}$ & $\mathrm{P}$ & $\mathrm{P}$ & $\mathrm{P}$ & $\mathrm{P}$ & $\mathrm{P}$ & $\mathrm{P}$ & $\mathrm{P}$ \\
\hline A.C.M. & $\mathrm{V}$ & 13,0 & $\mathrm{~F}$ & $\mathrm{P}$ & $\mathrm{P}$ & $\mathrm{P}$ & $\mathrm{P}$ & $\mathrm{P}$ & $P$ & $\mathrm{P}$ & $P$ & $\mathrm{P}$ & $P$ & $P$ & $\mathrm{P}$ & $P$ & $P$ \\
\hline E.C.M. & $\mathrm{V}$ & 13,0 & $\mathrm{~F}$ & $\mathrm{P}$ & $\mathrm{P}$ & $\mathrm{P}$ & $\mathrm{P}$ & $\mathrm{P}$ & $\mathrm{P}$ & $\mathrm{P}$ & $\mathrm{P}$ & $\mathrm{P}$ & $\mathrm{P}$ & $\mathrm{P}$ & $\mathrm{P}$ & $\mathrm{P}$ & $\mathrm{P}$ \\
\hline J.C.M.J. & $\mathrm{V}$ & 13,0 & $\bar{M}$ & $\mathrm{P}$ & $\mathrm{P}$ & $\mathrm{P}$ & $\mathrm{P}$ & $\mathrm{P}$ & $\mathrm{P}$ & $\mathrm{P}$ & $\mathrm{P}$ & $\mathrm{P}$ & $\mathrm{P}$ & $\mathrm{P}$ & $\mathrm{P}$ & $\mathrm{P}$ & $\mathrm{P}$ \\
\hline M.A.P.T. & $\mathrm{V}$ & 13,0 & $M$ & $P$ & $P$ & $\mathrm{P}$ & $\mathrm{P}$ & $\mathrm{P}$ & $P$ & $\mathrm{P}$ & $\mathrm{P}$ & $P$ & $\mathrm{P}$ & $\mathrm{P}$ & $P$ & $P$ & $\mathrm{P}$ \\
\hline P.B.J. & $\mathrm{V}$ & 13,7 & $M$ & $P$ & $P$ & $P$ & $P$ & - & $P$ & $P$ & $P$ & $P$ & $P$ & $P$ & $P$ & $P$ & $P$ \\
\hline R.G.M. & V & 13,3 & $\mathrm{M}$ & $\mathrm{P}$ & $P$ & $\mathrm{P}$ & $\mathrm{P}$ & $\mathrm{P}$ & $P$ & $\mathrm{P}$ & $\mathrm{P}$ & $\mathrm{P}$ & $\mathrm{P}$ & $\mathrm{P}$ & $\mathrm{P}$ & $P$ & $\mathrm{P}$ \\
\hline T.C.C.C. & $\mathrm{V}$ & 13,0 & $\mathrm{~F}$ & $P$ & $P$ & $P$ & $P$ & $\mathrm{P}$ & $\mathrm{P}$ & $P$ & $P$ & $P$ & $P$ & $\mathrm{P}$ & $P$ & $P$ & $\mathrm{P}$ \\
\hline M.Q.B. & $\mathrm{V}$ & 13,0 & $M$ & $P$ & $P$ & $\mathrm{P}$ & $P$ & $P$ & $P$ & $P$ & $P$ & $P$ & $P$ & $P$ & $P$ & $P$ & $P$ \\
\hline M.F.G. & V & 13,0 & $\mathrm{~F}$ & $P$ & $P$ & $P$ & $\mathrm{P}$ & $\mathrm{P}$ & $P$ & $\mathrm{P}$ & $\mathrm{P}$ & $P$ & $\mathrm{P}$ & $P$ & $P$ & $P$ & $\mathrm{P}$ \\
\hline M.G.T. & $\mathrm{V}$ & 13,6 & $\bar{M}$ & $\mathrm{P}$ & $\mathrm{P}$ & $\mathrm{P}$ & $\mathrm{P}$ & $\mathrm{P}$ & $P$ & $\mathrm{P}$ & $\mathrm{P}$ & $\mathrm{P}$ & $\mathrm{P}$ & $\mathrm{P}$ & $\mathrm{P}$ & $\mathrm{P}$ & $\mathrm{P}$ \\
\hline R.T.D.G. & $\mathrm{V}$ & 13,9 & $\mathrm{M}$ & $\mathrm{P}$ & $\mathrm{P}$ & $\mathrm{P}$ & $\mathrm{P}$ & $\mathrm{P}$ & $\mathrm{P}$ & $\mathrm{P}$ & $\mathrm{P}$ & $\mathrm{P}$ & $\mathrm{P}$ & $\mathrm{P}$ & $\mathrm{P}$ & $\mathrm{P}$ & $\mathrm{P}$ \\
\hline G.C.T.N. & V & 13,0 & $\mathrm{M}$ & - & $\mathrm{P}$ & $\mathrm{P}$ & $\mathrm{P}$ & $\mathrm{P}$ & $P$ & $\mathrm{P}$ & $\mathrm{P}$ & $\mathrm{P}$ & $P$ & $P$ & $\mathrm{P}$ & $\mathrm{P}$ & - \\
\hline E.L.C.S. & $\mathrm{V}$ & 13,4 & $\mathrm{M}$ & $\mathrm{P}$ & $\mathrm{P}$ & $\mathrm{P}$ & $\mathrm{P}$ & $\mathrm{P}$ & $\mathrm{P}$ & $\mathrm{P}$ & $\mathrm{P}$ & $\mathrm{P}$ & $P$ & $\mathrm{P}$ & $\mathrm{P}$ & $\mathrm{P}$ & $\mathrm{P}$ \\
\hline M.S. & $\mathrm{V}$ & 13,2 & $\mathrm{M}$ & $\mathrm{P}$ & $\mathrm{P}$ & $\mathrm{P}$ & $\mathrm{P}$ & $\mathrm{P}$ & $\mathrm{P}$ & $\mathrm{P}$ & $\mathrm{P}$ & $\mathrm{P}$ & $\mathrm{P}$ & $\mathrm{P}$ & $\mathrm{P}$ & $\mathrm{P}$ & $\mathrm{P}$ \\
\hline G.S.M. & $\mathrm{V}$ & 13,5 & $M$ & $P$ & $\mathrm{P}$ & $\mathrm{P}$ & $\mathrm{P}$ & $\mathrm{P}$ & $\mathrm{P}$ & $\mathrm{P}$ & $\mathrm{P}$ & $P$ & $\mathrm{P}$ & $P$ & $\mathrm{P}$ & $\mathrm{P}$ & $\mathrm{P}$ \\
\hline A.L.T.P. & $\mathrm{V}$ & 13,0 & $\mathrm{~F}$ & $\mathrm{P}$ & $\mathrm{P}$ & $\mathrm{P}$ & $\mathrm{P}$ & $\mathrm{P}$ & $\mathrm{P}$ & $\mathrm{P}$ & $\mathrm{P}$ & $\mathrm{P}$ & $\mathrm{P}$ & $\mathrm{P}$ & $\mathrm{P}$ & $\mathrm{P}$ & - \\
\hline R.C.L.A. & $\mathrm{V}$ & 13,3 & $\mathrm{~F}$ & $\mathrm{P}$ & $\mathrm{P}$ & $\mathrm{P}$ & $\mathrm{P}$ & $\mathrm{P}$ & $\mathrm{P}$ & $\mathrm{P}$ & $\mathrm{P}$ & $\mathrm{P}$ & $\mathrm{P}$ & $\mathrm{P}$ & $\mathrm{P}$ & $\mathrm{P}$ & $\mathrm{P}$ \\
\hline D.C.G.O. & $\mathrm{V}$ & 13,3 & $\mathrm{~F}$ & $\mathrm{P}$ & $\mathrm{P}$ & $\mathrm{P}$ & $\mathrm{P}$ & $\mathrm{P}$ & $\mathrm{P}$ & $\mathrm{P}$ & $\mathrm{P}$ & $\mathrm{P}$ & $\mathrm{P}$ & $\mathrm{P}$ & $\mathrm{P}$ & $\mathrm{P}$ & $\mathrm{P}$ \\
\hline F.C.B. & V & 13,5 & $\mathrm{~F}$ & $\mathrm{P}$ & $\mathrm{P}$ & $\mathrm{P}$ & $\mathrm{P}$ & $\mathrm{P}$ & $\mathrm{P}$ & $\mathrm{P}$ & $\mathrm{P}$ & $\mathrm{P}$ & $\mathrm{P}$ & $\mathrm{P}$ & $\mathrm{P}$ & $\mathrm{P}$ & $\mathrm{P}$ \\
\hline F.L.B. & $\mathrm{V}$ & 13,5 & $\mathrm{~F}$ & - & $\mathrm{P}$ & $\mathrm{P}$ & $\mathrm{P}$ & $\mathrm{P}$ & $\mathrm{P}$ & $\mathrm{P}$ & $\mathrm{P}$ & $\mathrm{P}$ & $\mathrm{P}$ & $\mathrm{P}$ & $\mathrm{P}$ & $\mathrm{P}$ & - \\
\hline A.P.B. & $\mathrm{V}$ & 13,6 & $\mathrm{~F}$ & $\mathrm{P}$ & $\mathrm{P}$ & $\mathrm{P}$ & $\mathrm{P}$ & $\mathrm{P}$ & $\mathrm{P}$ & $\mathrm{P}$ & $\mathrm{P}$ & $\mathrm{P}$ & $\mathrm{P}$ & $\mathrm{P}$ & $\mathrm{P}$ & $\mathrm{P}$ & $\mathrm{P}$ \\
\hline C.C.P. & $\mathrm{V}$ & 13,4 & $\mathrm{~F}$ & $\mathrm{P}$ & $\mathrm{P}$ & $\mathrm{P}$ & $\mathrm{P}$ & $\mathrm{P}$ & $\mathrm{P}$ & $\mathrm{P}$ & $\mathrm{P}$ & $\mathrm{P}$ & $\mathrm{P}$ & $\mathrm{P}$ & $\mathrm{P}$ & $\mathrm{P}$ & $\mathrm{P}$ \\
\hline F.Z. & $\mathrm{V}$ & 13,6 & $\bar{M}$ & $\mathrm{P}$ & $\mathrm{P}$ & $\mathrm{P}$ & $\mathrm{P}$ & $\mathrm{P}$ & $\mathrm{P}$ & $\mathrm{P}$ & $\mathrm{P}$ & $\mathrm{P}$ & $P$ & $\mathrm{P}$ & $\mathrm{P}$ & $\mathrm{P}$ & $\mathrm{P}$ \\
\hline R.P.F. & $\overline{\mathrm{H}}$ & 13,9 & $\mathrm{M}$ & $\mathrm{P}$ & $\mathrm{P}$ & $\mathrm{P}$ & $\mathrm{P}$ & $\mathrm{P}$ & $\mathrm{P}$ & $\mathrm{P}$ & $\mathrm{P}$ & $\mathrm{P}$ & $P$ & $\mathrm{P}$ & $\mathrm{P}$ & $\mathrm{P}$ & $\mathrm{P}$ \\
\hline A.C.D. & $\mathrm{H}$ & 13,0 & $F$ & $\mathrm{P}$ & $\mathrm{P}$ & $P$ & $P$ & $P$ & $P$ & $P$ & $P$ & $P$ & $P$ & $P$ & $P$ & $\mathrm{P}$ & $P$ \\
\hline F.S. & $\overline{\mathrm{H}}$ & 13,5 & $\bar{M}$ & $P$ & $P$ & $P$ & $P$ & $P$ & $P$ & $P$ & $P$ & $P$ & - & $P$ & $P$ & $P$ & $P$ \\
\hline E.C.L. & $\mathrm{H}$ & 13,0 & $\mathrm{~F}$ & $\mathrm{P}$ & $\mathrm{P}$ & $\mathrm{P}$ & $\mathrm{P}$ & $\mathrm{P}$ & $\mathrm{P}$ & $\mathrm{P}$ & $\mathrm{P}$ & $\mathrm{P}$ & $P$ & $\mathrm{P}$ & $\mathrm{P}$ & $\mathrm{P}$ & $\mathrm{P}$ \\
\hline R.F.E. & $\bar{H}$ & 13,0 & $M$ & $\mathrm{P}$ & $P$ & $P$ & $P$ & $P$ & $P$ & $P$ & $P$ & $\mathrm{P}$ & $P$ & $P$ & $P$ & $P$ & $P$ \\
\hline S.T.G. & $\mathrm{H}$ & 13,0 & $\mathrm{M}$ & $\mathrm{P}$ & $\mathrm{P}$ & $\mathrm{P}$ & $\mathrm{P}$ & $\mathrm{P}$ & $\mathrm{P}$ & $\mathrm{P}$ & $\mathrm{P}$ & $\mathrm{P}$ & $\mathrm{P}$ & $\mathrm{P}$ & $\mathrm{P}$ & $\mathrm{P}$ & $\mathrm{P}$ \\
\hline J.A.R.C.M. & $\overline{\mathrm{H}}$ & 13,9 & $\bar{M}$ & $\mathrm{P}$ & $\mathrm{P}$ & $\mathrm{P}$ & $\mathrm{P}$ & $\mathrm{P}$ & $P$ & $P$ & $\mathrm{P}$ & $\mathrm{P}$ & $P$ & $P$ & $\mathrm{P}$ & $P$ & $\mathrm{P}$ \\
\hline B.M.L. & $\mathrm{H}$ & 13,2 & $\mathrm{M}$ & $\mathrm{P}$ & $\mathrm{P}$ & $\mathrm{P}$ & $P$ & $P$ & $\mathrm{P}$ & $\mathrm{P}$ & $\mathrm{P}$ & $\mathrm{P}$ & $\mathrm{P}$ & $\mathrm{P}$ & $\mathrm{P}$ & $\mathrm{P}$ & $P$ \\
\hline R.O.B.A. & $\mathrm{H}$ & 13,0 & $M$ & $\mathrm{P}$ & $\mathrm{P}$ & $\mathrm{P}$ & $\mathrm{P}$ & $\mathrm{P}$ & $\mathrm{P}$ & $\mathrm{P}$ & $\mathrm{P}$ & $\mathrm{P}$ & $P$ & $\mathrm{P}$ & $\mathrm{P}$ & $\mathrm{P}$ & $\mathrm{P}$ \\
\hline C.F.Z.S. & $\overline{\mathrm{H}}$ & 13,0 & $\mathrm{~F}$ & $\mathrm{P}$ & $\mathrm{P}$ & $\mathrm{P}$ & $\mathrm{P}$ & $\mathrm{P}$ & $\mathrm{P}$ & $\mathrm{P}$ & $\mathrm{P}$ & $\mathrm{P}$ & $P$ & $\mathrm{P}$ & $\mathrm{P}$ & $\mathrm{P}$ & $\mathrm{P}$ \\
\hline M.P.P. & $\mathrm{H}$ & 13,5 & $\mathrm{~F}$ & $\mathrm{P}$ & $\mathrm{P}$ & $\mathrm{P}$ & $\mathrm{P}$ & $P$ & $\mathrm{P}$ & $\mathrm{P}$ & $\mathrm{P}$ & $\mathrm{P}$ & $P$ & $\mathrm{P}$ & $\mathrm{P}$ & $\mathrm{P}$ & $\mathrm{P}$ \\
\hline C.L.C. & $\mathrm{H}$ & 13,2 & $\mathrm{~F}$ & $\mathrm{P}$ & $\mathrm{P}$ & $\mathrm{P}$ & $\mathrm{P}$ & $\mathrm{P}$ & $\mathrm{P}$ & $\mathrm{P}$ & $\mathrm{P}$ & $\mathrm{P}$ & $\mathrm{P}$ & $\mathrm{P}$ & $\mathrm{P}$ & $\mathrm{P}$ & $\mathrm{P}$ \\
\hline J.A.A.C. & $\overline{\mathrm{H}}$ & 13,9 & $\bar{M}$ & $\mathrm{P}$ & $\mathrm{P}$ & $\mathrm{P}$ & $\mathrm{P}$ & $\mathrm{P}$ & $\mathrm{P}$ & $P$ & $\mathrm{P}$ & $\mathrm{P}$ & $\mathrm{P}$ & $\mathrm{P}$ & $\mathrm{P}$ & $P$ & $\mathrm{P}$ \\
\hline P.B.B.M. & $\mathrm{H}$ & 13,8 & $\mathrm{~F}$ & $\mathrm{P}$ & $\mathrm{P}$ & $\mathrm{P}$ & $\mathrm{P}$ & $\mathrm{P}$ & $\mathrm{P}$ & $\mathrm{P}$ & $\mathrm{P}$ & $\mathrm{P}$ & $P$ & $\mathrm{P}$ & $\mathrm{P}$ & $\mathrm{P}$ & $\mathrm{P}$ \\
\hline M.H.T. & $\mathrm{H}$ & 13,3 & $F$ & - & $P$ & $P$ & $P$ & $P$ & $P$ & $P$ & $P$ & $P$ & $P$ & $P$ & $P$ & $P$ & - \\
\hline F.B. & $\mathrm{H}$ & 13,5 & $\mathrm{~F}$ & $\mathrm{P}$ & $\mathrm{P}$ & $\mathrm{P}$ & $\mathrm{P}$ & $P$ & $\mathrm{P}$ & $P$ & $\mathrm{P}$ & $\mathrm{P}$ & $\mathrm{P}$ & $\mathrm{P}$ & $\mathrm{P}$ & $\mathrm{P}$ & $\mathrm{P}$ \\
\hline A.B.S.M. & $\mathrm{H}$ & 13,0 & $\mathrm{~F}$ & $\mathrm{P}$ & $\mathrm{P}$ & $\mathrm{P}$ & $\mathrm{P}$ & - & $\mathrm{P}$ & $\mathrm{P}$ & $\mathrm{P}$ & $\mathrm{P}$ & - & $\mathrm{P}$ & $\mathrm{P}$ & $\mathrm{P}$ & $\mathrm{P}$ \\
\hline C.B.J. & $\mathrm{H}$ & 13,5 & $\mathrm{~F}$ & $\mathrm{P}$ & $\mathrm{P}$ & $\mathrm{P}$ & $\mathrm{P}$ & $\mathrm{P}$ & $\mathrm{P}$ & $\mathrm{P}$ & $\mathrm{P}$ & $\mathrm{P}$ & $\mathrm{P}$ & $\mathrm{P}$ & $\mathrm{P}$ & $\mathrm{P}$ & $\mathrm{P}$ \\
\hline D.E.H. & $\mathrm{H}$ & 13,6 & $F$ & $P$ & $P$ & $P$ & $P$ & $P$ & $P$ & $\mathrm{P}$ & $P$ & $P$ & $\mathrm{P}$ & $P$ & $\mathrm{P}$ & $P$ & $P$ \\
\hline D.A.M. & $\mathrm{H}$ & 13,6 & $\mathrm{M}$ & $\mathrm{P}$ & $\mathrm{P}$ & $\mathrm{P}$ & $\mathrm{P}$ & $\mathrm{P}$ & $\mathrm{P}$ & $\mathrm{P}$ & $\mathrm{P}$ & $\mathrm{P}$ & $\mathrm{P}$ & $\mathrm{P}$ & $\mathrm{P}$ & $\mathrm{P}$ & $\mathrm{P}$ \\
\hline M.L.P. & $\mathrm{H}$ & 13,0 & $\mathrm{~F}$ & $\mathrm{P}$ & $\mathrm{P}$ & $\mathrm{P}$ & $\mathrm{P}$ & $\mathrm{P}$ & $P$ & $\mathrm{P}$ & $\mathrm{P}$ & $\mathrm{P}$ & $\mathrm{P}$ & $\mathrm{P}$ & $\mathrm{P}$ & $\mathrm{P}$ & $\mathrm{P}$ \\
\hline L.B. & $\mathrm{H}$ & 13,6 & $\mathrm{~F}$ & $\mathrm{P}$ & $\mathrm{P}$ & $\mathrm{P}$ & $\mathrm{P}$ & $\mathrm{P}$ & $\mathrm{P}$ & $\mathrm{P}$ & $\mathrm{P}$ & $\mathrm{P}$ & $\mathrm{P}$ & $\mathrm{P}$ & $\mathrm{P}$ & $\mathrm{P}$ & $\mathrm{P}$ \\
\hline A.P.M.B. & $\mathrm{H}$ & 13,0 & $\mathrm{~F}$ & $\mathrm{P}$ & $\mathrm{P}$ & $\mathrm{P}$ & $\mathrm{P}$ & $\mathrm{P}$ & $\mathrm{P}$ & $\mathrm{P}$ & $\mathrm{P}$ & $\mathrm{P}$ & $\mathrm{P}$ & $\mathrm{P}$ & $\mathrm{P}$ & $\mathrm{P}$ & $\mathrm{P}$ \\
\hline P.S.E. & $\mathrm{H}$ & 13,5 & $\mathrm{~F}$ & $\mathrm{P}$ & $\mathrm{P}$ & $P$ & $\mathrm{P}$ & $\mathrm{P}$ & $P$ & $\mathrm{P}$ & $\mathrm{P}$ & $\mathrm{P}$ & $\mathrm{P}$ & $P$ & $\mathrm{P}$ & $P$ & $\mathrm{P}$ \\
\hline J.R.N. & $\mathrm{H}$ & 13,9 & $\mathrm{M}$ & $\mathrm{P}$ & $\mathrm{P}$ & $\mathrm{P}$ & $\mathrm{P}$ & $\mathrm{P}$ & $\mathrm{P}$ & $\mathrm{P}$ & $\mathrm{P}$ & $\mathrm{P}$ & $\mathrm{P}$ & $\mathrm{P}$ & $\mathrm{P}$ & $\mathrm{P}$ & $\mathrm{P}$ \\
\hline E.A. & $\mathrm{H}$ & 13,8 & $\mathrm{M}$ & $\mathrm{P}$ & $\mathrm{P}$ & $\mathrm{P}$ & $\mathrm{P}$ & $\mathrm{P}$ & $\mathrm{P}$ & $\mathrm{P}$ & $\mathrm{P}$ & $\mathrm{P}$ & $\mathrm{P}$ & $\mathrm{P}$ & $\mathrm{P}$ & $\mathrm{P}$ & $\mathrm{P}$ \\
\hline C.S.D. & $\mathrm{H}$ & 13,0 & $\mathrm{~F}$ & $\mathrm{P}$ & $\mathrm{P}$ & $\mathrm{P}$ & $\mathrm{P}$ & $\mathrm{P}$ & $\mathrm{P}$ & $\mathrm{P}$ & $\mathrm{P}$ & $\mathrm{P}$ & $\mathrm{P}$ & $\mathrm{P}$ & $\mathrm{P}$ & $\mathrm{P}$ & $\mathrm{P}$ \\
\hline R.V.D. & $\mathrm{H}$ & 13,1 & $M$ & $\mathrm{P}$ & $\mathrm{P}$ & $\mathrm{P}$ & $\mathrm{P}$ & $\mathrm{P}$ & $\mathrm{P}$ & $\mathrm{P}$ & $\mathrm{P}$ & $\mathrm{P}$ & $\mathrm{P}$ & $\mathrm{P}$ & $\mathrm{P}$ & $\mathrm{P}$ & $\mathrm{P}$ \\
\hline G.R.P. & $\mathrm{H}$ & 13,3 & $\mathrm{~F}$ & $P$ & $\mathrm{P}$ & $P$ & $\mathrm{P}$ & $\mathrm{P}$ & $P$ & $\mathrm{P}$ & $\mathrm{P}$ & $\mathrm{P}$ & $\mathrm{P}$ & $P$ & $\mathrm{P}$ & $P$ & $\mathrm{P}$ \\
\hline I.M.L. & $\mathrm{H}$ & 13,5 & $\mathrm{~F}$ & $\mathrm{P}$ & $\mathrm{P}$ & $\mathrm{P}$ & $\mathrm{P}$ & $\mathrm{P}$ & $\mathrm{P}$ & $\mathrm{P}$ & $\mathrm{P}$ & $\mathrm{P}$ & $\mathrm{P}$ & $\mathrm{P}$ & $\mathrm{P}$ & $\mathrm{P}$ & $\mathrm{P}$ \\
\hline
\end{tabular}


Tabela A-21

\begin{tabular}{|c|c|c|c|c|c|c|c|c|c|c|c|c|c|c|c|c|c|}
\hline Nome & Grupo & Idade & Gênero & 37 & 36 & 35 & 34 & 33 & 32 & 31 & 41 & 42 & 43 & 44 & 45 & 46 & 47 \\
\hline R.A.A. & V & 13,8 & $M$ & $\mathrm{P}$ & $\mathrm{P}$ & $\mathrm{P}$ & $\mathrm{P}$ & $\mathrm{P}$ & $\mathrm{P}$ & $\mathrm{P}$ & $\mathrm{P}$ & $\mathrm{P}$ & $\mathrm{P}$ & $\mathrm{P}$ & $\mathrm{P}$ & $\mathrm{P}$ & $\mathrm{P}$ \\
\hline D.F.D. & $\mathrm{V}$ & 13,1 & $\mathrm{M}$ & $P$ & $\mathrm{P}$ & $\mathrm{P}$ & $\mathrm{P}$ & $\mathrm{P}$ & $\mathrm{P}$ & $\mathrm{P}$ & $\mathrm{P}$ & $\mathrm{P}$ & $\mathrm{P}$ & $P$ & $\mathrm{P}$ & $P$ & $\mathrm{P}$ \\
\hline A.C.M. & $\mathrm{V}$ & 13,0 & $\mathrm{~F}$ & $\mathrm{P}$ & $\mathrm{P}$ & $\mathrm{P}$ & $\mathrm{P}$ & $\mathrm{P}$ & $\mathrm{P}$ & $P$ & $\mathrm{P}$ & $P$ & $P$ & $P$ & $P$ & $\mathrm{P}$ & $P$ \\
\hline E.C.M. & $\mathrm{V}$ & 13,0 & $\mathrm{~F}$ & $\mathrm{P}$ & $\mathrm{P}$ & $\mathrm{P}$ & $\mathrm{P}$ & $\mathrm{P}$ & $\mathrm{P}$ & $\mathrm{P}$ & $\mathrm{P}$ & $\mathrm{P}$ & $P$ & $P$ & $\mathrm{P}$ & $\mathrm{P}$ & $\mathrm{P}$ \\
\hline J.C.M.J. & $\mathrm{V}$ & 13,0 & $\bar{M}$ & $\mathrm{P}$ & $\mathrm{P}$ & $\mathrm{P}$ & $\mathrm{P}$ & $\mathrm{P}$ & $\mathrm{P}$ & $\mathrm{P}$ & $\mathrm{P}$ & $\mathrm{P}$ & $P$ & $\mathrm{P}$ & $\mathrm{P}$ & $\mathrm{P}$ & $\mathrm{P}$ \\
\hline M.A.P.T. & $\mathrm{V}$ & 13,0 & $\bar{M}$ & $\mathrm{P}$ & $\mathrm{P}$ & $\mathrm{P}$ & $\mathrm{P}$ & $P$ & $P$ & $P$ & $\mathrm{P}$ & $P$ & $P$ & $P$ & $\mathrm{P}$ & $\mathrm{P}$ & $\mathrm{P}$ \\
\hline P.B.J. & V & 13,7 & $\mathrm{M}$ & $\mathrm{P}$ & $P$ & $\mathrm{P}$ & $P$ & $P$ & $P$ & $\mathrm{P}$ & $\mathrm{P}$ & $\mathrm{P}$ & $P$ & $P$ & $\mathrm{P}$ & $\mathrm{P}$ & $\mathrm{P}$ \\
\hline R.G.M. & V & 13,3 & $\mathrm{M}$ & $\mathrm{P}$ & $\mathrm{P}$ & $P$ & $\mathrm{P}$ & $\mathrm{P}$ & $\mathrm{P}$ & $\mathrm{P}$ & $\mathrm{P}$ & $\mathrm{P}$ & $P$ & $P$ & $\mathrm{P}$ & $P$ & $\mathrm{P}$ \\
\hline T.C.C.C. & $\mathrm{V}$ & 13,0 & $\mathrm{~F}$ & $P$ & $P$ & $P$ & $\mathrm{P}$ & $P$ & $P$ & $\mathrm{P}$ & $P$ & $P$ & $P$ & $P$ & $\mathrm{P}$ & $\mathrm{P}$ & $P$ \\
\hline M.Q.B. & $\mathrm{V}$ & 13,0 & $M$ & $\mathrm{P}$ & $P$ & $P$ & $P$ & $P$ & $P$ & $P$ & $P$ & $P$ & $\mathrm{P}$ & $P$ & $P$ & $P$ & $\mathrm{P}$ \\
\hline M.F.G. & V & 13,0 & $\mathrm{~F}$ & $\mathrm{P}$ & $P$ & $\mathrm{P}$ & $P$ & $P$ & $P$ & $\mathrm{P}$ & $\mathrm{P}$ & $P$ & $\mathrm{P}$ & $P$ & $P$ & $\mathrm{P}$ & $P$ \\
\hline M.G.T. & $\mathrm{V}$ & 13,6 & $\bar{M}$ & $\mathrm{P}$ & $\mathrm{P}$ & $\mathrm{P}$ & $\mathrm{P}$ & $\mathrm{P}$ & $\mathrm{P}$ & $\mathrm{P}$ & $\mathrm{P}$ & $\mathrm{P}$ & $\mathrm{P}$ & $P$ & $\mathrm{P}$ & $\mathrm{P}$ & $\mathrm{P}$ \\
\hline R.T.D.G. & $\mathrm{V}$ & 13,9 & $\bar{M}$ & $\mathrm{P}$ & $\mathrm{P}$ & $\mathrm{P}$ & $\mathrm{P}$ & $\mathrm{P}$ & $\mathrm{P}$ & $\mathrm{P}$ & $\mathrm{P}$ & $\mathrm{P}$ & $\mathrm{P}$ & $P$ & $\mathrm{P}$ & $\mathrm{P}$ & $\mathrm{P}$ \\
\hline G.C.T.N. & V & 13,0 & $\mathrm{M}$ & $P$ & $P$ & $P$ & $P$ & $P$ & $P$ & $P$ & $P$ & $P$ & $P$ & $P$ & $P$ & $P$ & $P$ \\
\hline E.L.C.S. & $\mathrm{V}$ & 13,4 & $\bar{M}$ & $\mathrm{P}$ & $\mathrm{P}$ & $\mathrm{P}$ & $\mathrm{P}$ & $\mathrm{P}$ & $\mathrm{P}$ & $\mathrm{P}$ & $\mathrm{P}$ & $\mathrm{P}$ & $\mathrm{P}$ & $P$ & $\mathrm{P}$ & $\mathrm{P}$ & $\mathrm{P}$ \\
\hline M.S. & $\mathrm{V}$ & 13,2 & $\bar{M}$ & $\mathrm{P}$ & $\mathrm{P}$ & $\mathrm{P}$ & $\mathrm{P}$ & $\mathrm{P}$ & $\mathrm{P}$ & $\mathrm{P}$ & $\mathrm{P}$ & $\mathrm{P}$ & $\mathrm{P}$ & $\mathrm{P}$ & $\mathrm{P}$ & $\mathrm{P}$ & $\mathrm{P}$ \\
\hline G.S.M. & $\mathrm{V}$ & 13,5 & $M$ & $\mathrm{P}$ & $\mathrm{P}$ & $\mathrm{P}$ & $P$ & $P$ & $P$ & $P$ & $\mathrm{P}$ & $\mathrm{P}$ & $P$ & $P$ & $\mathrm{P}$ & $P$ & $\mathrm{P}$ \\
\hline A.L.T.P. & $\mathrm{V}$ & 13,0 & $\mathrm{~F}$ & $\mathrm{P}$ & $\mathrm{P}$ & $\mathrm{P}$ & $\mathrm{P}$ & $\mathrm{P}$ & $\mathrm{P}$ & $\mathrm{P}$ & $\mathrm{P}$ & $\mathrm{P}$ & $\mathrm{P}$ & $\mathrm{P}$ & $\mathrm{P}$ & $\mathrm{P}$ & $\mathrm{P}$ \\
\hline R.C.L.A. & $\mathrm{V}$ & 13,3 & $\mathrm{~F}$ & $\mathrm{P}$ & $\mathrm{P}$ & $\mathrm{P}$ & $\mathrm{P}$ & $\mathrm{P}$ & $\mathrm{P}$ & $\mathrm{P}$ & $\mathrm{P}$ & $\mathrm{P}$ & $\mathrm{P}$ & $\mathrm{P}$ & $\mathrm{P}$ & $\mathrm{P}$ & $\mathrm{P}$ \\
\hline D.C.G.O. & $\mathrm{V}$ & 13,3 & $\mathrm{~F}$ & $\mathrm{P}$ & $\mathrm{P}$ & $\mathrm{P}$ & $\mathrm{P}$ & $\mathrm{P}$ & $\mathrm{P}$ & $\mathrm{P}$ & $P$ & $\mathrm{P}$ & $\mathrm{P}$ & $\mathrm{P}$ & $\mathrm{P}$ & $P$ & $\mathrm{P}$ \\
\hline F.C.B. & V & 13,5 & $\mathrm{~F}$ & $\mathrm{P}$ & $\mathrm{P}$ & $\mathrm{P}$ & $\mathrm{P}$ & $\mathrm{P}$ & $\mathrm{P}$ & $\mathrm{P}$ & $\mathrm{P}$ & $\mathrm{P}$ & $P$ & $P$ & $\mathrm{P}$ & $\mathrm{P}$ & $\mathrm{P}$ \\
\hline F.L.B. & V & 13,5 & $F$ & $\mathrm{P}$ & $\mathrm{P}$ & $\mathrm{P}$ & $\mathrm{P}$ & $\mathrm{P}$ & $\mathrm{P}$ & $\mathrm{P}$ & $\mathrm{P}$ & $\mathrm{P}$ & $\mathrm{P}$ & $P$ & $\mathrm{P}$ & $\mathrm{P}$ & $\mathrm{P}$ \\
\hline A.P.B. & $\mathrm{V}$ & 13,6 & $\mathrm{~F}$ & $\mathrm{P}$ & $\mathrm{P}$ & $\mathrm{P}$ & $\mathrm{P}$ & $\mathrm{P}$ & $\mathrm{P}$ & $\mathrm{P}$ & $P$ & $\mathrm{P}$ & $\mathrm{P}$ & $\mathrm{P}$ & $\mathrm{P}$ & $\mathrm{P}$ & $\mathrm{P}$ \\
\hline C.C.P. & $\mathrm{V}$ & 13,4 & $F$ & $\mathrm{P}$ & $\mathrm{P}$ & $\mathrm{P}$ & $\mathrm{P}$ & $\mathrm{P}$ & $\mathrm{P}$ & $\mathrm{P}$ & $\mathrm{P}$ & $\mathrm{P}$ & $P$ & $P$ & $\mathrm{P}$ & $\mathrm{P}$ & $\mathrm{P}$ \\
\hline F.Z. & $\mathrm{V}$ & 13,6 & $\bar{M}$ & $\mathrm{P}$ & $\mathrm{P}$ & $\mathrm{P}$ & $\mathrm{P}$ & $\mathrm{P}$ & $\mathrm{P}$ & $\mathrm{P}$ & $\bar{P}$ & $\mathrm{P}$ & $P$ & $P$ & $\mathrm{P}$ & $P$ & $\mathrm{P}$ \\
\hline R.P.F. & $\mathrm{H}$ & 13,9 & $\bar{M}$ & $\mathrm{P}$ & $\mathrm{P}$ & $\mathrm{P}$ & $\mathrm{P}$ & $\mathrm{P}$ & $\mathrm{P}$ & $\mathrm{P}$ & $\mathrm{P}$ & $\mathrm{P}$ & $\mathrm{P}$ & $\mathrm{P}$ & $\mathrm{P}$ & $\mathrm{P}$ & $\mathrm{P}$ \\
\hline A.C.D. & $\mathrm{H}$ & 13,0 & $F$ & $\mathrm{P}$ & $P$ & $P$ & $P$ & $\mathrm{P}$ & $P$ & $P$ & $P$ & $P$ & $P$ & $P$ & $P$ & $P$ & $P$ \\
\hline F.S. & $\overline{\mathrm{H}}$ & 13,5 & $\bar{M}$ & $P$ & $P$ & $P$ & $P$ & $P$ & $P$ & $P$ & $\bar{P}$ & $P$ & $P$ & $P$ & $P$ & $\bar{P}$ & $P$ \\
\hline E.C.L. & $\mathrm{H}$ & 13,0 & $\mathrm{~F}$ & $\mathrm{P}$ & $\mathrm{P}$ & $\mathrm{P}$ & $\mathrm{P}$ & $\mathrm{P}$ & $\mathrm{P}$ & $\mathrm{P}$ & $P$ & $\mathrm{P}$ & $\mathrm{P}$ & $\mathrm{P}$ & $\mathrm{P}$ & $\mathrm{P}$ & $\mathrm{P}$ \\
\hline R.F.E. & $\mathrm{H}$ & 13,0 & $\bar{M}$ & $P$ & $P$ & $P$ & $P$ & $\mathrm{P}$ & $\mathrm{P}$ & $P$ & $P$ & $P$ & $P$ & $P$ & $P$ & $P$ & $P$ \\
\hline S.T.G. & $\mathrm{H}$ & 13,0 & $\bar{M}$ & $\mathrm{P}$ & $\mathrm{P}$ & $\mathrm{P}$ & $\mathrm{P}$ & $\mathrm{P}$ & $\mathrm{P}$ & $\mathrm{P}$ & $P$ & $\mathrm{P}$ & $\mathrm{P}$ & $\mathrm{P}$ & $\mathrm{P}$ & $P$ & $\mathrm{P}$ \\
\hline J.A.R.C.M. & $\bar{H}$ & 13,9 & $\mathrm{M}$ & $\mathrm{P}$ & $P$ & $\mathrm{P}$ & $\mathrm{P}$ & $\mathrm{P}$ & $\mathrm{P}$ & $\mathrm{P}$ & $P$ & $\mathrm{P}$ & $\mathrm{P}$ & $P$ & $\mathrm{P}$ & $\mathrm{P}$ & $\mathrm{P}$ \\
\hline B.M.L. & $\overline{\mathrm{H}}$ & 13,2 & $\bar{M}$ & $\mathrm{P}$ & $\mathrm{P}$ & $\mathrm{P}$ & $\mathrm{P}$ & $\mathrm{P}$ & $\mathrm{P}$ & $\mathrm{P}$ & $P$ & $\mathrm{P}$ & $\mathrm{P}$ & $P$ & $\mathrm{P}$ & $\mathrm{P}$ & $P$ \\
\hline R.O.B.A. & $\mathrm{H}$ & 13,0 & $M$ & $\mathrm{P}$ & $\mathrm{P}$ & $\mathrm{P}$ & $\mathrm{P}$ & $\mathrm{P}$ & $\mathrm{P}$ & $\mathrm{P}$ & $P$ & $\mathrm{P}$ & $P$ & $\mathrm{P}$ & $\mathrm{P}$ & $P$ & $\mathrm{P}$ \\
\hline C.F.Z.S. & $\overline{\mathrm{H}}$ & 13,0 & $\mathrm{~F}$ & $\mathrm{P}$ & $\mathrm{P}$ & $\mathrm{P}$ & $\mathrm{P}$ & $\mathrm{P}$ & $\mathrm{P}$ & $\mathrm{P}$ & $P$ & $\mathrm{P}$ & $P$ & $\mathrm{P}$ & $\mathrm{P}$ & $\mathrm{P}$ & $\mathrm{P}$ \\
\hline M.P.P. & $\mathrm{H}$ & 13,5 & $\mathrm{~F}$ & $\mathrm{P}$ & $\mathrm{P}$ & - & $\mathrm{P}$ & $\mathrm{P}$ & $\mathrm{P}$ & $\mathrm{P}$ & $P$ & $P$ & $P$ & $P$ & - & $\mathrm{P}$ & $\mathrm{P}$ \\
\hline C.L.C. & $\mathrm{H}$ & 13,2 & $\mathrm{~F}$ & $\mathrm{P}$ & $\mathrm{P}$ & $\mathrm{P}$ & $\mathrm{P}$ & $\mathrm{P}$ & $\mathrm{P}$ & $\mathrm{P}$ & $\mathrm{P}$ & $\mathrm{P}$ & $\mathrm{P}$ & $\mathrm{P}$ & $\mathrm{P}$ & $\mathrm{P}$ & $\mathrm{P}$ \\
\hline J.A.A.C. & $\overline{\mathrm{H}}$ & 13,9 & $\bar{M}$ & $\mathrm{P}$ & $\mathrm{P}$ & $\mathrm{P}$ & $\mathrm{P}$ & $\mathrm{P}$ & $\mathrm{P}$ & $\mathrm{P}$ & $P$ & $\mathrm{P}$ & $P$ & $\mathrm{P}$ & $\mathrm{P}$ & $\mathrm{P}$ & $\mathrm{P}$ \\
\hline P.B.B.M. & $\mathrm{H}$ & 13,8 & $\mathrm{~F}$ & $\mathrm{P}$ & $\mathrm{P}$ & $\mathrm{P}$ & $\mathrm{P}$ & $\mathrm{P}$ & $\mathrm{P}$ & $\mathrm{P}$ & $P$ & $\mathrm{P}$ & $P$ & $\mathrm{P}$ & $\mathrm{P}$ & $\mathrm{P}$ & $\mathrm{P}$ \\
\hline M.H.T. & $\mathrm{H}$ & 13,3 & $F$ & $\mathrm{P}$ & $P$ & $P$ & $P$ & $P$ & $P$ & $P$ & $P$ & $P$ & $P$ & $P$ & $P$ & $P$ & $\mathrm{P}$ \\
\hline F.B. & $\mathrm{H}$ & 13,5 & $\mathrm{~F}$ & $\mathrm{P}$ & $\mathrm{P}$ & $\mathrm{P}$ & $\mathrm{P}$ & $\mathrm{P}$ & $\mathrm{P}$ & $\mathrm{P}$ & $\mathrm{P}$ & $\mathrm{P}$ & $P$ & $P$ & $\mathrm{P}$ & $\mathrm{P}$ & $\mathrm{P}$ \\
\hline A.B.S.M. & $\mathrm{H}$ & 13,0 & $\mathrm{~F}$ & $\mathrm{P}$ & $\mathrm{P}$ & $\mathrm{P}$ & $\mathrm{P}$ & $\mathrm{P}$ & $\mathrm{P}$ & $\mathrm{P}$ & $\mathrm{P}$ & $\mathrm{P}$ & $P$ & $\mathrm{P}$ & $\mathrm{P}$ & $\mathrm{P}$ & $\mathrm{P}$ \\
\hline C.B.J. & $\mathrm{H}$ & 13,5 & $\mathrm{~F}$ & $\mathrm{P}$ & $\mathrm{P}$ & $\mathrm{P}$ & $\mathrm{P}$ & $\mathrm{P}$ & $\mathrm{P}$ & $\mathrm{P}$ & $\mathrm{P}$ & $\mathrm{P}$ & $\mathrm{P}$ & $\mathrm{P}$ & $\mathrm{P}$ & $\mathrm{P}$ & $\mathrm{P}$ \\
\hline D.E.H. & $\mathrm{H}$ & 13,6 & $\mathrm{~F}$ & $\mathrm{P}$ & $\mathrm{P}$ & $\mathrm{P}$ & $\mathrm{P}$ & $\mathrm{P}$ & $\mathrm{P}$ & $\mathrm{P}$ & $\mathrm{P}$ & $\mathrm{P}$ & $\mathrm{P}$ & $\mathrm{P}$ & $\mathrm{P}$ & $\mathrm{P}$ & $\mathrm{P}$ \\
\hline D.A.M. & $\mathrm{H}$ & 13,6 & $\bar{M}$ & $\mathrm{P}$ & $\mathrm{P}$ & $\mathrm{P}$ & $\mathrm{P}$ & $\mathrm{P}$ & $\mathrm{P}$ & $\mathrm{P}$ & $\mathrm{P}$ & $\mathrm{P}$ & $\mathrm{P}$ & $\mathrm{P}$ & $\mathrm{P}$ & $\mathrm{P}$ & $\mathrm{P}$ \\
\hline M.L.P. & $\overline{\mathrm{H}}$ & 13,0 & $\mathrm{~F}$ & $\mathrm{P}$ & $P$ & $\mathrm{P}$ & $\mathrm{P}$ & $\mathrm{P}$ & $\mathrm{P}$ & $\mathrm{P}$ & $P$ & $\mathrm{P}$ & $\mathrm{P}$ & $\mathrm{P}$ & $\mathrm{P}$ & $\mathrm{P}$ & $\mathrm{P}$ \\
\hline L.B. & $\overline{\mathrm{H}}$ & 13,6 & $\mathrm{~F}$ & $\mathrm{P}$ & $\mathrm{P}$ & $\mathrm{P}$ & $\mathrm{P}$ & $\mathrm{P}$ & $\mathrm{P}$ & $\mathrm{P}$ & $\mathrm{P}$ & $\mathrm{P}$ & $\mathrm{P}$ & $\mathrm{P}$ & $\mathrm{P}$ & $\mathrm{P}$ & $\mathrm{P}$ \\
\hline A.P.M.B. & $\mathrm{H}$ & 13,0 & $\mathrm{~F}$ & $\mathrm{P}$ & $\mathrm{P}$ & $\mathrm{P}$ & $\mathrm{P}$ & $\mathrm{P}$ & $\mathrm{P}$ & $\mathrm{P}$ & $\mathrm{P}$ & $\mathrm{P}$ & $\mathrm{P}$ & $\mathrm{P}$ & $\mathrm{P}$ & $\mathrm{P}$ & $\mathrm{P}$ \\
\hline P.S.E. & $\overline{\mathrm{H}}$ & 13,5 & $\mathrm{~F}$ & $P$ & $\mathrm{P}$ & $\mathrm{P}$ & $\mathrm{P}$ & $\mathrm{P}$ & $P$ & $P$ & $\mathrm{P}$ & $\mathrm{P}$ & $\mathrm{P}$ & $\mathrm{P}$ & $P$ & $\mathrm{P}$ & $\mathrm{P}$ \\
\hline J.R.N. & $\mathrm{H}$ & 13,9 & $\mathrm{M}$ & $\mathrm{P}$ & $\mathrm{P}$ & $\mathrm{P}$ & $\mathrm{P}$ & $\mathrm{P}$ & $\mathrm{P}$ & $\mathrm{P}$ & $\mathrm{P}$ & $\mathrm{P}$ & $\mathrm{P}$ & $\mathrm{P}$ & $\mathrm{P}$ & $\mathrm{P}$ & $\mathrm{P}$ \\
\hline E.A. & $\mathrm{H}$ & 13,8 & M & $\mathrm{P}$ & $\mathrm{P}$ & $\mathrm{P}$ & $\mathrm{P}$ & $\mathrm{P}$ & $\mathrm{P}$ & $P$ & $P$ & $\mathrm{P}$ & $\mathrm{P}$ & $\mathrm{P}$ & $\mathrm{P}$ & $\mathrm{P}$ & $\mathrm{P}$ \\
\hline C.S.D. & $\overline{\mathrm{H}}$ & 13,0 & $\bar{F}$ & $\mathrm{P}$ & $\mathrm{P}$ & $\mathrm{P}$ & $\mathrm{P}$ & $\mathrm{P}$ & $\mathrm{P}$ & $\mathrm{P}$ & $P$ & $\mathrm{P}$ & $\mathrm{P}$ & $P$ & $\mathrm{P}$ & $\mathrm{P}$ & $\mathrm{P}$ \\
\hline R.V.D. & $\mathrm{H}$ & 13,1 & $M$ & $\mathrm{P}$ & $P$ & $\mathrm{P}$ & $\mathrm{P}$ & $\mathrm{P}$ & $\mathrm{P}$ & $\mathrm{P}$ & $P$ & $\mathrm{P}$ & $\mathrm{P}$ & $P$ & $\mathrm{P}$ & $\mathrm{P}$ & $\mathrm{P}$ \\
\hline G.R.P. & $\mathrm{H}$ & 13,3 & $\mathrm{~F}$ & $P$ & $\mathrm{P}$ & $\mathrm{P}$ & $P$ & $P$ & $P$ & $P$ & $\mathrm{P}$ & $\mathrm{P}$ & $\mathrm{P}$ & $P$ & $P$ & $\mathrm{P}$ & $\mathrm{P}$ \\
\hline I.M.L. & $\mathrm{H}$ & 13,5 & $F$ & $\mathrm{P}$ & $\mathrm{P}$ & $\mathrm{P}$ & $\mathrm{P}$ & $\mathrm{P}$ & $\mathrm{P}$ & $\mathrm{P}$ & $P$ & $\mathrm{P}$ & $\mathrm{P}$ & $\mathrm{P}$ & $\mathrm{P}$ & $\mathrm{P}$ & $\mathrm{P}$ \\
\hline
\end{tabular}




\section{Universidade de São Paulo Faculdade de Odontologia de Bauru}

Al. Dr. Octávio Pinheiro Brisolla, 9-75 - Bauru-SP - CEP 17012-901 - C.P. 73 PABX (0XXI4)235-8000 - FAX (0XXl4)223-4679

Comitê de Éfica em Pesquisa

Of. $n^{\circ}$ CEP/11 2002FOB

Bauru, 20 de agosto de 2002

Senhor Professor,

Ternos o prazer de informar-lhe que após anälise por este Comitê de Ética em Pesquisa em Seres Humanos, seu pedido de alteração do titulo do projelo de pesquisa intitulado "Estudo longitudinal comparativo da seqüência de erupçäo dentária dos hemi-arcos direitos e esquerdos em crianças brasileiras, leucodermas, de origem mediterrânea, da regiăo de Bauru, dos 5 aos 13 anos, utilizando radiografias ortopantomográficas e modelos de gesso" de autoria da C.D. Leniana Santos Neves, sob a sua crientação, para 'Estudo comparativo da maturaçāo e da sequiência de erupçāo dos dentes permanentes entre jovens leucodermas com padröes de crescimento vertical e horizontal', foi aprovado considerando que sua metodologia não sofreu modificaçōes.

Sendo o que nos apresenta para o momento, despedimo-nos,

Alenciosamente,

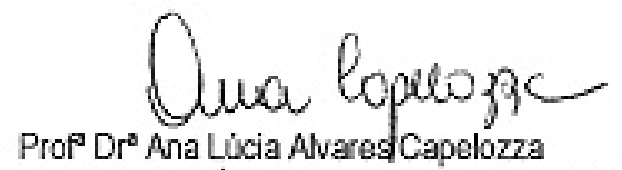

Coordenadora do Comitê de Ėtica em Pesquisa em Seres Humanos

$\| m^{\circ}$ Sr. Prof. Dr. ARNALDO PINZAN

DD. Docente do Departamento de Odontopediatria, Ortodontia e Saúde Coletiva (Saúde Coleliva) 